Luiz Eduardo Malta Corradini

\title{
RELAÇÃO DE SUBSTITUIÇÃO DE AÇÕES EM OPERAÇÕES DE INCORPORAÇÃO E INCORPORAÇÃO DE AÇÕES
}

\author{
Dissertação de Mestrado
}

Orientador: Professor Doutor José Alexandre Tavares Guerreiro

Faculdade de Direito da Universidade de São Paulo

São Paulo 


\title{
RELAÇÃO DE SUBSTITUIÇÃO DE AÇÕES EM OPERAÇÕES DE INCORPORAÇÃO E INCORPORAÇÃO DE AÇÕES
}

\author{
Dissertação para obtenção do título de \\ Mestre em Direito Comercial no Curso de \\ Pós-Graduação stricto sensu pela Faculdade \\ de Direito da Universidade de São Paulo.
}

Orientador: Professor Doutor José Alexandre Tavares Guerreiro

Faculdade de Direito da Universidade de São Paulo São Paulo 
Banca Examinadora 


\section{RESUMO}

O presente trabalho visa a estudar a regulamentação existente a respeito da relação de substituição de ações em operações de incorporação de sociedades e incorporação de ações. Para tanto, serão abordados os dispositivos legais, as posições doutrinárias e as interpretações da jurisprudência sobre o assunto no Brasil e em Direito Comparado. No primeiro capítulo, são estudados os institutos da incorporação e da incorporação de ações, analisando-se a natureza jurídica dessas operações e os procedimentos para realização de cada uma delas. No segundo capítulo, examina-se propriamente a relação de substituição de ações e sua natureza jurídica para, na sequência, analisarmos o arcabouço legal em que se insere a determinação da relação de troca de ações. Nesse contexto, são abordados os critérios, parâmetros e requisitos que norteiam a sua definição, bem como os mecanismos legais previstos pela legislação societária para compor os diferentes interesses envolvidos, notadamente aqueles dos acionistas minoritários e do controlador. O terceiro capítulo analisa algumas especificidades relativas às operações de incorporação que envolvem companhias abertas, operações de incorporação englobando sociedades sob controle comum, diferentes relações de substituição de ações entre ações de diferentes espécies e classes e, por fim, entre ações da mesma espécie e classe. Finalmente, a conclusão arremata as principais ideias discutidas ao longo deste trabalho.

Palavras-chave: Incorporação, incorporação de ações, relação de troca, princípio da realidade do capital social, interesse social, valor justo, tratamento equitativo, deveres fiduciários, abuso de poder de controle. 


\begin{abstract}
This paper aims at analyzing the existing regulation regarding the share exchange ratio in mergers and merger of shares (incorporação de ações). For this purpose, this work will examine the legal provisions, the different doctrinal positions and case law understandings relating to this matter under Brazilian Law and Comparative Law. The first chapter of this paper presents the concepts of the merger and merger of shares and analyzes the nature of such transactions and the procedures necessary for their performance. The second chapter examines the share exchange ratio and its nature, followed by an analysis of the legal environment in which such share exchange ratio is determined. In this sense, this paper analyzes the criteria, parameters and requirements that drive the determination of the share exchange ratio, as well as the legal provisions established by Corporate Law to assure that all interests involved in such transactions are addressed, mainly those of minority shareholders as opposed to those of the controlling shareholders. The third chapter analyzes certain special situations concerning mergers and mergers of shares that involve publicly held corporations or corporations under common control. This chapter also analyzes special cases regarding the establishment of different share exchange ratios between different types and classes of shares and between shares of the same type and class. Finally, the conclusion of this work summarizes the main ideas discussed herein.
\end{abstract}

Key-words: Merger, merger of shares (incorporação de ações), exchange ratio, veracity of the corporate capital (realidade do capital social), interest of the company (interesse social), fair value, equal treatment of shareholders, fiduciary duties, abuse of control. 


\section{AGRADECIMENTOS}

O caminho de uma dissertação de mestrado não é solitário. Ficam aqui, portanto, os meus mais honestos agradecimentos a todos aqueles que me ajudaram nesta empreitada.

Em primeiro lugar, agradeço à minha mãe, ZULEIKA, pelo apoio incondicional que só as mães sabem dar e por todo o incentivo que me trouxe até aqui. A todos da minha família, por estarem ao meu lado, sempre.

Agradeço também imensamente ao meu orientador, Prof. Dr. JOSÉ ALEXANDRE TAVARES GUERREIRO, pela orientação neste mestrado e por me dar a oportunidade de fazer parte de um círculo tão incrível de pessoas, a quem devo muito do meu aprendizado. Ao Prof. Dr. EDUARDO SECCHI MUNHOZ, pelas contribuições na minha banca de qualificação e ao Prof. Dr. ERASMO VALLADÃO AZEVEDO E NOVAES FRANÇA, a quem devo agradecer não apenas as proveitosas ponderações no exame de qualificação, mas também por ter sido quem me despertou o interesse pelo direito societário desde as aulas de graduação.

Não posso deixar de mencionar meus amigos queridos que sempre me socorreram. Em especial, agradeço muitíssimo à CARLA MOSNA TOMAZELLA, sempre pronta para rever um capítulo, enviar material ou discutir uma ideia aqui e ali, provando que uma amizade verdadeira não conhece fronteiras ou fuso-horário. Ao BRUNO DI DOTTO e à MARIA DA GLÓRIA FERRAZ DE ALMEIDA PRADO, com quem dividi quase que diariamente as dores e as delícias da vida na pós-graduação. Tantos outros merecem menção: MARÍlia DE CARA, MARIANA BORGES, DANIEl CASElTA, LÍVIA AMARAL, DANIELA RIOS, VINÍCIUS FADANELLI, LAURA PATELLA e ainda muitos que não conseguiria citar.

Também preciso agradecer aos meus chefes, EDUARDO BOULOS, MILANA MARTINS e AUGUSTO RODRIGUES, pela compreensão com os meus horários para que eu pudesse me dedicar a esta dissetação. Ao EDUARDO, especialmente, serei sempre grato pelo apoio em momentos difíceis no escritório e na vida. 


\section{SUMÁRIO}

INTRODUÇÃO

1. ANÁLISE DAS OPERAÇÕES DE INCORPORAÇÃO DE SOCIEDADE E INCORPORAÇÃO DE AÇÕES E A RELAÇÃO DE SUBSTITUIÇÃO DE AÇÕES

1.1 Incorporação de Sociedade

1.1.1 Operação de Incorporação de Sociedade e Natureza Jurídica ....................... 14

1.1.2 Procedimento de Incorporação para Sociedades Anônimas .......................... 27

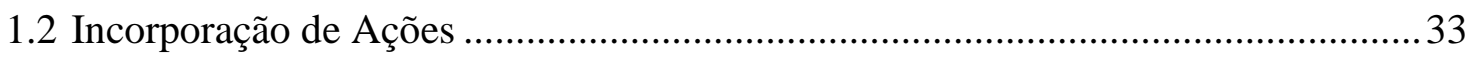

1.2.1 Operação de Incorporação de Ações e Natureza Jurídica ...............................33

1.2.2 Procedimento de Incorporação de Ações para Sociedades Anônimas ............ 39

1.3 Incorporação de Sociedades e Incorporação de Ações .......................................... 41

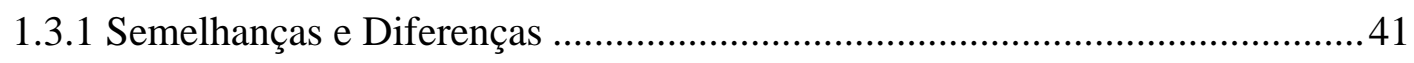

1.3.2 Importância das Operações de Incorporação ............................................... 44

2. RELAÇÃO DE SUBSTITUIÇÃO DE AÇÕES: CONCEITO, DETERMINAÇÃO

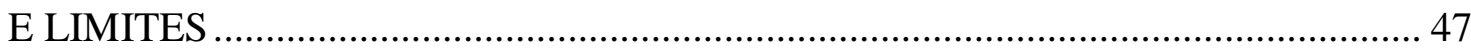

2.1 Conceito de Relação de Substituição de Ações...................................................... 47

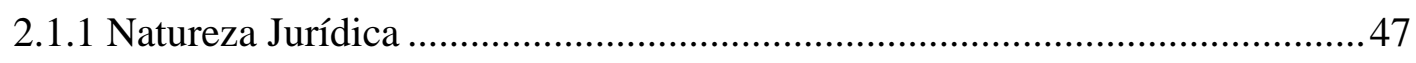

2.1.2 Importância da Relação de Substituição de Ações .......................................57

2.1.3 Contraprestações Admitidas e Frações de Ações .........................................59

2.1.4 Inexistência de Relação de Substituiçãa ........................................................ 64

2.1.5 Relação de Troca e Outros Valores Mobiliários.............................................. 68

2.2 Determinação da Relação de Substituição de Ações ............................................. 71

2.2.1 Critérios para Fixação da Relação de Substituição......................................... 79

2.2.2 Avaliação de Patrimônio ou Ações e Formação do Capital ............................89

2.2.3 Parecer do Conselho Fiscal ou de Peritos ........................................................ 96

2.2.4 Relação de Troca e Liberdade Contratual.................................................. 101

2.3 Limites à Determinação da Relação de Substituição de Ações .............................. 106

2.3.1 Preservação da Realidade do Capital Social................................................ 108

2.3.2 Proteção dos Interesses dos Minoritários .................................................... 115

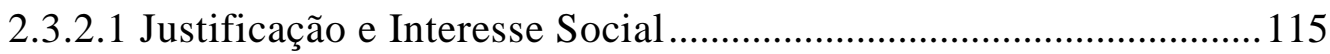


2.3.2.1.1 Critérios para Atendimento do Interesse Social em Operações de Incorporação

2.3.2.1.2 Determinação da Relação de Substituição como Convergência dos Interesses Sociais

2.3.2.2 Valor Justo em Operações de Incorporação .................................. 144

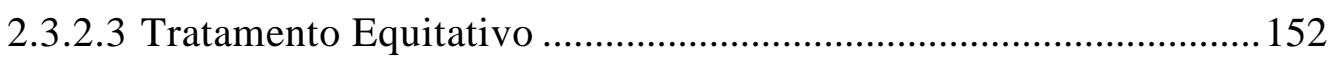

2.3.2.4 Informação e Justificação Sobre os Termos da Operação ........... 168

2.3.2.5 Deveres Fiduciários dos Administradores ................................... 180

2.3.2.6 Abuso de Poder de Controle ........................................................... 185

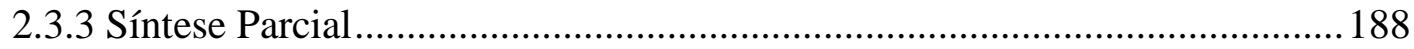

3. RELAÇÃO DE SUBSTITUIÇÃO DE AÇÕES EM SITUAÇÕES ESPECIAIS ....... 191

3.1 Operações de Incorporação Envolvendo Companhias Abertas .............................. 191

3.1.1 Edital de Audiência Pública SDM n. 04/2013 ............................................. 194

3.2 Operações Envolvendo Sociedades sob Controle Comum ..................................... 198

3.2.1 Relação de Substituição de Ações e Avaliação dos Patrimônios ..................204

3.2.2 Deveres Fiduciários da Administração ........................................................2 211

3.2.3 Parecer de Orientação CVM n. 35/2008 .................................................... 214

3.3 Operações Envolvendo Relações de Substituição entre Ações de Espécies

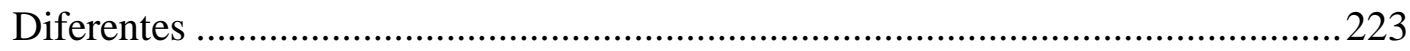

3.3.1 Modificação de Direitos dos Acionistas e Aprovação das Operações .........223

3.3.2 Relações de Substituição Diferenciadas entre Ações de Espécies Diferentes

3.4 Operações Envolvendo Relações de Substituição Diferentes para Ações de

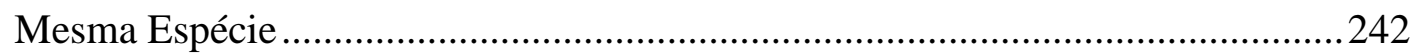

3.4.1 Prêmio de Controle em Operações de Incorporação....................................243

3.4.2 Possibilidade de Relações de Substituição Diferenciadas Perante os Demais Limites Impostos pela Lei das S.A. .............................................249

3.4.3 Parecer de Orientação CVM n. 34/2006 .......................................................257

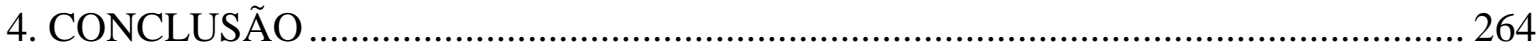

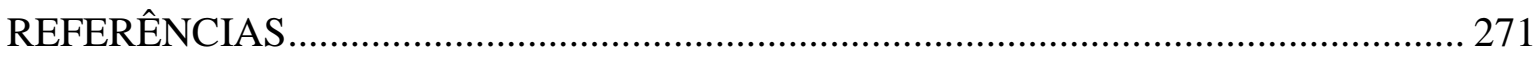




\section{INTRODUÇÃO}

É sabido que os institutos da incorporação e da incorporação de ações alteram significativamente a estrutura das sociedades e a situação de seus acionistas, ${ }^{1}$ gerando, muitas vezes, situações de conflito de interesses por parte do acionista controlador ou dos administradores que se traduzem em abuso de poder de controle ou quebra de deveres fiduciários da administração e do controlador. Por essa razão, existe na nossa lei societária, notadamente na Lei n. 6.404 de 15 de dezembro de 1976 (Lei das S.A.), extensa regulamentação sobre tais operações, justamente com o intuito de tentar garantir o equilíbrio entre os diversos interesses das partes envolvidas, principalmente entre controladores e minoritários. $^{2}$

\footnotetext{
R. KRAAKMAN et. al traduziram muito bem essa problemática dizendo: "The relationships among the participants in the firm can be revolutionized by a merger. A shareholder's ownership stake can be diluted, transformed, or, in some jurisdictions, cashed out. A preferred stockholder's accrued dividend may be wiped out. A shareholder in a widely-dispersed firm can find itself a shareholder in a controlled firm. A shareholder in a firm with no antitakeover protections can wake up a shareholder in a firm that is effectively takeover-proof. A shareholder in a privately-held company can end up a shareholder of a public-held company or vice-versa. The overwhelming problems, however, are related to price: a shareholder can miss the opportunity to sell its shares at a high price or be forced to sell at too low price" (The Anatomy of Corporate Law - A Comparative and Functional Approach, 2. ed., New York: Oxford University Press, 2009, p. 197). A citação é particularmente interessante para este trabalho porque também demonstra que os maiores problemas no contexto de uma operação de incorporação estão ligados à questão do "preço" de tais operações, o que, sob o direito brasileiro, traduz-se na relação de troca de tais operações como discutiremos adiante. No mesmo sentido, G. FERRI diz que "indubbiamente la compenetrazione in unica organizzazione di più organizzazioni autonome importa sempre uma modificazione essenziale nella posizione del socio singolo, e ciò non soltano perchè questa posizione è relativa a uma organizzazione più ampia e quindi il peso dela partecipazione si modifica; non soltanto perchè in fusione del rapporto di cambio il peso della partecipazione può ulteriormente ridursi, ma anche perchè questa posizione si determina in uma società che può avere um diverso oggeto e uma diversa struttura organizativa" (Le società, 2. ed., Torino: Utet, 1985, p. 690).

2 Cf. afirma L. G. P. B. LEÃES, o ordenamento jurídico tem por intuito a tutela de interesses e as normas que o integram pressupõem sempre uma ponderação entre os interesses em jogo e se orientam no sentido de compô-los na melhor maneira possível. Isso não significa que a cada norma corresponda um único interesse, pois um único interesse pode ser tutelado por um grupo de normas, enquanto uma única norma pode tutelar vários interesses simultâneos. Em específico, a sociedade anônima constitui um ordenamento jurídico autônomo (derivado, evidentemente), caracterizada por um feixe de normas que visa a compor uma gama de interesses que se cruzam na organização societária: interesses particulares dos acionistas, dos credores, da companhia e até da comunidade. Como nos outros ordenamentos, a tutela de tais interesses pode ser feita por normas materiais, que geram direitos e deveres, e normas instrumentais, que cuidam de um desenvolvimento ordenado na atividade empresarial objeto da sociedade. As reorganizações societárias fazem parte do horizonte da vida das sociedades e afetam brutalmente a sua estrutura. Natural, portanto, que sejam alvo de normas tanto materiais, que criam direitos e obrigações, como instrumentais, que ditam o procedimento a ser seguido para que se consiga tutelar os interesses afetados, as quais serão foco deste estudo (Incorporação de companhia controlada, Revista de Direito Mercantil Industrial, Econômico e Financeiro, n. 94, São Paulo: RT, 1994, p. 87-88).
} 
Na concretização das operações de incorporação, ${ }^{3}$ é geralmente necessário determinar a relação de substituição que se dará entre as ações dos acionistas da empresa incorporada, no caso de incorporação de sociedades, ou dos acionistas que têm suas ações incorporadas, no caso de incorporação de ações, e as novas ações da incorporadora que serão atribuídas a tais acionistas. A determinação dessa relação de substituição, ou relação de troca de ações como é também denominada, é sempre um ponto crítico e delicado, pois é ela que determinará a distribuição entre os acionistas do novo patrimônio social - fruto da junção dos patrimônios das empresas envolvidas -, bem como definirá a distribuição dos poderes políticos entre tais acionistas. Não por outra razão, a relação de troca foi considerada a pedra angular das operações de incorporação. ${ }^{4}$

Dada sua importância, entre as diversas questões atinentes às operações de incorporação, o presente trabalho tem por escopo estudar a regulamentação existente para a determinação da relação de troca de ações em operações de incorporação envolvendo sociedades anônimas.

Com esse intuito, no primeiro capítulo, serão brevemente estudados os institutos da incorporação de sociedades e da incorporação de ações, analisando a natureza jurídica e o procedimento a ser seguido na implementação de cada uma dessas operações. Essa análise é fundamental para determinar a natureza de cada instituto com o intuito de definir o feixe de regras aplicáveis sobre cada um deles, bem como para contextualizar a questão da relação de substituição de ações e entender onde se inserem os problemas que com ela se relacionam.

Em seguida, no segundo capítulo, pretende-se desenvolver o conceito da relação de substituição de ações, demonstrar a sua importância e explorar algumas especificidades relativas exclusivamente à relação de troca em si, como, por exemplo, sua natureza jurídica, as diferentes contraprestações admitidas em outras legislações e o

Neste trabalho, usaremos a expressão “operações de incorporação" ou o termo "incorporações” para nos referir, genericamente, tanto às operações tradicionais de incorporação de sociedades como às incorporações de ações, diferenciando-as expressamente quando for o caso.

4 Cf. A. LAMY FILHO; J. L. BUlHõES PEDREIRA, A Lei das S.A. (pressupostos, elaboração, aplicação), Rio de Janeiro: Renovar, 1992, p. 679. A. PÉREZ TROYA completa dizendo que "la determinación del tipo de canje continue constituyendo para los socios el 'teatro de todos los peligros', a la vez que genera inseguridad en torno a la realización misma de determinadas fusiones" (La determinación del tipo de canje en la fusión de sociedades, Madrid: Marcial Pons, 1998, p. 23). 
tratamento legislativo conferido às frações de ações. Na sequência, o capítulo analisará também o arcabouço legal em que se insere a determinação da relação de substituição, abordando os critérios, parâmetros e requisitos que norteiam sua definição, bem como os mecanismos legais previstos pela legislação societária para composição de todos os interesses envolvidos, notadamente aqueles dos acionistas minoritários.

Feita a análise geral dos parâmetros legais que balizam a determinação da relação de substituição de ações, será também estudada a regulação aplicável a casos especiais de determinação da relação de troca de ações. Nesse sentido, o terceiro capítulo analisará algumas especificidades atinentes às operações de incorporações que envolvam companhias abertas, operações de incorporação englobando sociedades sob controle comum, relação de substituição entre ações de diferentes espécies e classes e, por fim, relações de troca diferenciadas entre ações da mesma espécie e classe.

Em todo o trabalho, além do estudo das leis existentes, da jurisprudência e das diferentes posições doutrinárias a respeito do tema, será também imprescindível considerar as estratégias de regulação praticadas pela Comissão de Valores Mobiliários $(\underline{\mathrm{CVM}})^{5}$ por meio de suas instruções normativas e decisões administrativas, haja vista a importância cada vez maior da autarquia como agente regulador e de prevenção e punição dos agentes de mercado em operações de incorporação. Exemplificativamente, a CVM se pronunciou sobre aspectos de incorporação e incorporação de ações de sociedades em dois pareceres de orientação, o Parecer de Orientação CVM n. 34, de 18 de agosto de 2006 (PO CVM 34) e o Parecer de Orientação CVM n. 35, de 1. ${ }^{\circ}$ de setembro de 2008 (PO CVM 35), os quais serão também especificamente analisados neste trabalho.

Este estudo recorrerá também à análise da legislação, doutrina e jurisprudência do direito estrangeiro quando essas puderem auxiliar na resolução das questões surgidas no direito pátrio ou na análise de estratégias alternativas de regulação. Especificamente, serão estudadas as legislações dos países da Europa Continental, da Inglaterra, dos Estados 
Unidos (mais precisamente o Estado de Delaware) ${ }^{6}$ e da Argentina. Mais do que realizar uma análise estanque e segmentada da doutrina e da legislação estrangeira, pretende-se inserir o contraponto do direito estrangeiro ao longo dos capítulos e apenas quando tais discussões puderem ser proveitosas para mostrar soluções alternativas às questões que serão aqui discutidas.

Como primeira limitação ao nosso tema, este trabalho se restringirá à análise das sociedades anônimas por três motivos principais: a enorme quantidade de operações de incorporação envolvendo sociedades anônimas abertas que ocorreram no mercado acionário brasileiro nos últimos anos, ${ }^{7}$ o fato de a regulação das incorporações ter sido, desde o princípio, voltada às sociedades anônimas ${ }^{8}$ e a maior convergência dos institutos de direito comparado para esse tipo societário, quando comparado com as sociedades de pessoas das diferentes legislações. ${ }^{9}$

Além disso, dada a vasta extensão da matéria a respeito de incorporação de sociedades e a incorporação de ações, este estudo tomará como pressuposto as definições já assentadas pela doutrina e jurisprudência sobre o tema e tentará analisar a natureza jurídica e o procedimento de tais operações apenas na medida necessária para permitir a discussão do tema da relação de substituição das ações.

O trabalho também se limita a tratar das incorporações como institutos societários, embora saibamos que o fenômeno das concentrações empresariais não se

6 A multiplicidade legislativa norte-americana e a grande amplitude regulatória conferida aos diferentes estados faz com que o estudo de uma regulação norte-americana de âmbito nacional torne-se menos acurada e proveitosa. Por essa razão, o foco de análise será a legislação do Estado de Delaware por sua importância e por servir de ponto de referência na resolução de inúmeros conflitos societários. Em publicação distribuída pelo governo de Delaware em 2007, consta que mais da metade das companhias listadas na Fortune 500 eram constituídas em Delaware. Cf. L. S. BLACK, Why Corporations Choose Delaware, 2007, disponível em: 〈http://corp.delaware.gov/whycorporations_web.pdf >, acesso em: 12 fev. 2012, p. 1.

7 A própria característica do tipo societário adotado em que, na maior parte das vezes, os recursos aportados são mais importantes do que as contribuições pessoais dos sócios, facilita as operações de reestruturação societária nas sociedades anônimas (R. SZTAJN, Fusão, incorporação e cisão de sociedades: formas de reorganização da estrutura societária na Lei n. 9457/97, in: W. BULGARELLI (Coord.), Reforma da Lei das Sociedades por Ações, São Paulo: Pioneira, 1998, p. 132).

8 Até a promulgação do Código Civil (Lei n. 10.406, de 10 de janeiro de 2002), dada a inexistência de normas em outros diplomas legais, todas as incorporações, mesmo aquelas envolvendo apenas as sociedades de pessoas, eram regradas pela Lei das S.A.

9 Nesse sentido, vide C. M. TOMAZELlA, Proteção de acionistas e credores nas operações de incorporação envolvendo Sociedades Anônimas, dissertação de mestrado apresentada à Faculdade de Direito da Universidade de São Paulo, 2011, p. 3. 
esgota nesse campo do direito, ou mesmo na área jurídica e, por isso, não serão completamente ignoradas as demais vertentes quando elas forem fundamentais para o entendimento dos institutos previstos pela lei societária. ${ }^{10}$

Por fim, não será especificamente estudado o instituto da fusão. Primeiramente, porque a sua utilização pelos agentes do mercado é remota, sendo largamente substituído pelas incorporações. ${ }^{11} \mathrm{Em}$ segundo lugar, porque as questões aqui discutidas para as incorporações de sociedades valeriam também para o instituto da fusão dadas a semelhança dos procedimentos nessas operações e a equivalência do resultado final, qual seja, a unificação de duas sociedades. ${ }^{12}$

10 Embora saibamos dos reflexos existentes em diversas esferas, a princípio, este estudo não analisará as implicações das operações de incorporação no direito concorrencial, tributário, consumidor, trabalhista etc. (vide em sentido semelhante, R. SZTAJN, Fusão, incorporação e cisão... cit., p. 135).

11 A maior utilização das incorporações em comparação com as fusões decorre de algumas vantagens trazidas por aquelas, entre elas, preservação da personalidade jurídica de pelo menos uma das sociedades (em geral, a que é de maior dimensão e reputação no mercado) ou de ambas, no caso das incorporações de ações; redução das formalidades quando comparada à constituição de uma nova companhia e redução da necessidade de averbação da unificação das empresas nos registros públicos de propriedade dos bens. Além disso, a legislação tributária permite um melhor aproveitamento dos prejuízos fiscais na incorporação, enquanto na fusão há total perda de tais prejuízos (vide N. EIZIRIK, $A$ Lei das S/A comentada, São Paulo: Quartier Latin, 2011, v. 3, p. 245; e I. MUNIZ; A. CASTELLO BRANCO, Fusões e aquisições - aspectos fiscais e societários, São Paulo: Quartier Latin, 2007, p. 180 e ss.). As fusões, em geral, somente ocorrem quando as empresas a serem fundidas são de dimensões semelhantes e nenhum dos grupos empresariais aceita ser formalmente absorvido pelo outro (nesse sentido, vide A. LAMY FILHO; J. L. BUlhões PEDREIRA (Coord.), Direito das companhias, Rio de Janeiro: Forense, 2009, v. 2, p. 1746).

12 Não por outra razão, em várias legislações estrangeiras, os institutos de fusão e incorporação são tratados como um único negócio, com duas modalidades: fusão propriamente dita, correspondente à nossa fusão, e fusão imprópria, ou por absorção, correspondente ao que a Lei das S.A. chamou de incorporação (cf. A. LAMY FILHO; J. L. BULHÕES PEDREIRA (Coord.), Direito das companhias, v. 2., cit., p. 1745). A unificação dos dois institutos também se justifica sob o argumento de que as diferenças entre a fusão e a incorporação não afetam a essência do instituto e devem ser relegadas a aspectos secundários (cf. A. DE A. GONÇALVES NETO, A fusão, a incorporação e a cisão na lei de sociedade por ações, Revista de Direito Mercantil Industrial, Econômico e Financeiro, n. 23, São Paulo: RT, 1976, p. 74; C. TOMAZElla, Proteção de acionistas e credores... cit., p. 8; R. SZTAJn, Fusão, incorporação e cisão... cit., p. 143 e J. GARRIGUES; R. URIA, Comentario a la Ley de Sociedades Anónimas, Madrid: Instituto de Estudios Politicos, 1953, t. II, p. 651-652). Por essa razão, algumas referências feitas às "fusões" neste trabalho quando tratamos da legislação estrangeira devem ser entendidas como também aplicáveis às incorporações. 


\section{ANÁLISE DAS OPERAÇÕES DE INCORPORAÇÃO DE SOCIEDADE E INCORPORAÇÃO DE AÇÕES E A RELAÇÃO DE SUBSTITUIÇÃO DE AÇÕES}

O objetivo deste capítulo inicial é apresentar de maneira sucinta os institutos da incorporação de sociedades e da incorporação de ações de modo que se contextualize a questão da relação de substituição de ações e se entenda onde se inserem os problemas que com ela se relacionam. Com esse intuito, analisaremos a natureza jurídica, o procedimento e os principais mecanismos, efeitos e consequências dos institutos da incorporação de sociedades e da incorporação de ações. Além disso, o capítulo pretende discutir a importância de tais operações no atual cenário econômico brasileiro, demonstrando a relevância da análise de questões que surgem no âmbito dessas operações, entre elas, notadamente, a questão das relações de substituição das ações.

\subsection{Incorporação de Sociedade}

\subsubsection{Operação de Incorporação de Sociedade e Natureza Jurídica}

As operações de incorporação não existiram desde sempre nas diversas legislações. Pelo contrário, a necessidade de se prever a possibilidade de companhias se reestruturarem tomou corpo aos poucos nos diversos países.

Em uma fase inicial, a possibilidade de alteração da estrutura da sociedade era raramente mencionada e aparecia escassamente nas legislações sob as figuras de aumento e redução de capital social. ${ }^{13}$

Posteriormente, em uma segunda fase, referências à fusão e à transformação começam a surgir nos códigos comerciais do fim do século XIX e começo do século XX, embora a regulação de tais operações ainda enfrentasse algumas dificuldades como a

13 Cf. A. Menezes Cordeiro, Manual de direito das sociedades, 2. ed., Coimbra: Almedina, 2007, v. 1, p. 952. 
exigência de aprovação unânime dos sócios e a dissolução da sociedade com a renúncia de cada sócio relativa às suas quotas da liquidação. ${ }^{14}$

Apenas em uma terceira fase é que as operações de incorporação passaram a ser reguladas e previstas nas legislações de diversos países. ${ }^{15}$ No âmbito da União Europeia, vigora atualmente a Diretiva 2011/35/UE do Parlamento Europeu e do Conselho, datada de 5 de abril de 2011 (Diretiva 2011/35), que alterou a Diretiva 78/855/CEE de 9 de outubro de 1978, ambas regulando as operações de fusão de sociedade anônimas e que, naturalmente, influenciaram as legislações dos países membros. Entre elas, citamos o Codice Civile na Itália, a Ley 3/2009 na Espanha, o Code de Commerce na França, o Código de Sociedades Comerciais em Portugal e o Companies Act no Reino Unido. Em Delaware, as operações de incorporação são reguladas pela Delaware General Corporation Law, bem como pela jurisprudência.

No Brasil, o Decreto-lei n. 2.627 de 26 de setembro de 1940 inaugura a regulação das operações de incorporação, tratando delas no seu art. 152 e seguintes. ${ }^{16}$ Hoje, como se sabe, as operações de incorporação envolvendo sociedades anônimas são reguladas pela Lei das S.A. e, no caso das companhias abertas, também por instruções normativas promulgadas pela CVM, principalmente a Instrução CVM n. 319 de 3 de dezembro de 1999 (ICVM 319), além de outros instrumentos editados pela autarquia como pareceres de orientação.

Seguindo o texto do Decreto-lei n. 2.627/1940, a Lei das S.A. definiu no seu art. 227 as incorporações como a operação ${ }^{17}$ pela qual uma ou mais sociedades são absorvidas por outra, que lhes sucede em todos os direitos e obrigações. ${ }^{18-19}$

14 Cf. W. Bulgarelli, Fusões, incorporações e cisões de sociedades, 5. ed., São Paulo: Atlas, 2000, p. 116.

15 Cf. A. Menezes CordeIro, Manual de direito das sociedades cit., 2007, p. 960. Vide também C. TOMAZELlA, Proteção de acionistas... cit., p. 11.

16 Decreto-lei n. 2.627/1940: “Art. 152. A incorporação é a operação pela qual uma ou mais sociedades são absorvidas por outra, que lhes sucede em todos os direitos e obrigações".

17 Cf. N. EIZIRIK, operação representa conjunto de atos interligados, processos ou procedimentos, dispostos em uma ordem necessária e que conduzem a um efeito jurídico final, no qual cada ato pressupõe o precedente e prepara o subsequente (A Lei das S/A comentada... cit., p. 211 e 246). Vide também L. G. P. B. LEÃES, Incorporação de companhia controlada... cit., p. 95. 
Assim, o negócio jurídico de incorporação serve para unificar duas ou mais sociedades, no qual se extinguem as sociedades incorporadas e sobrevive a sociedade incorporadora. Nessas operações, portanto, ocorre a transmissão da totalidade do patrimônio $^{20}$ da sociedade incorporada ao patrimônio da sociedade incorporadora, com sucessão universal de todos os direitos e obrigações da incorporada pela incorporadora e extinção da sociedade incorporada. ${ }^{21}$

Como um primeiro efeito jurídico das operações de incorporação, temos a transmissão total e automática do patrimônio da incorporada para a incorporadora mediante sucessão universal. ${ }^{22} \mathrm{~A}$ ideia de sucessão universal implica, a princípio, que todas as relações, reais, obrigacionais, ativas, passivas, substanciais ou processuais, transmitem-se para a incorporadora. ${ }^{23}$ Isso é dizer que todos os bens, direitos e obrigações, sejam eles direitos substantivos ou processuais, migram do patrimônio da incorporada para o patrimônio da incorporadora. ${ }^{24}$

18 Lei das S.A.: "Art. 227. A incorporação é a operação pela qual uma ou mais sociedades são absorvidas por outra, que lhes sucede em todos os direitos e obrigações".

19 Essa definição não é exclusiva da Lei das S.A. Outras legislações também regulam as incorporações de modo substancialmente análogo. A título exemplificativo, definição bastante semelhante consta (i) no art. 3..$^{\circ}$ Diretiva 2011/35; (ii) arts. 97(1) e 112 do Código de Sociedades Comerciais de Portugal; (iii) arts. 22 e 23(1) da Ley 3/2009 da Espanha; (iv) arts. L236-1 e L-236-3(i) do Code de Commerce da França; e (v) art. 82, da Ley n. 19.550 da Argentina.

O conceito jurídico de patrimônio corresponde a uma universalidade de direitos, composto de direitos e obrigações pecuniários de uma pessoa (cf. E. VALlADÃO A. e N. FRANÇA, Temas de direito societário, falimentar e teoria da empresa, São Paulo: Malheiros, 2009, p. 234; e M. A. DOMINGUES DE ANDRADE, Teoria geral da relação jurídica, Coimbra: Almedina, 2003, v. 1, p. 205).

21 Cf. inciso II do art. 219 da Lei das S.A. Nas palavras de L. G. P. B. LEÃES, "a lei não inclui como causa de dissolução, mas sim, de extinção da incorporada (art. 219, II), não havendo, portanto, na operação, partilha do ativo líquido da sociedade transmitente entre os sócios" (Incorporação de companhia controlada... cit., p. 89). No mesmo sentido, vide M. CARVAlHOSA, Comentários à Lei de Sociedades Anônimas, v. 4, t. I, 4. ed., São Paulo: Saraiva, 2009, p. 270; e E. L. TEIXEIRA; J. A. TAVAreS GUERREIRO, Das Sociedades Anônimas no direito brasileiro, São Paulo: Bushatsky, 1979, v. 2, p. 666.

22 Observe-se que a sucessão universal decorre de lei e não pode ser afastada contratualmente, cf. STF, $6{ }^{\text {a }}$ Turma, REsp n. 252.867/SP (2000/0028097-6), rel. Min. Vicente Leal, j. 16.11.2000.

23 Cf. F. GALgano, Diritto Commerciale. Le Società: Contrato di Società. Società di Persone. Società per Azioni, Altre Società di Capitali. Società Cooperative, Bologna: Zanichelli, 2005, p. 502.

24 Excetuam-se das regras da sucessão universal aquelas obrigações que são, por natureza, intransmissíveis, i.e., aquelas que pressupõem a existência da incorporada como sujeito de direitos ou aquelas de natureza orgânica, como as mantidas com os administradores (cf. F. GALGANO, Diritto Commerciale...cit., p. 502). 
Um segundo efeito é a extinção, não a dissolução, da sociedade incorporada, sem que seja necessária sua liquidação. ${ }^{25}$

Um terceiro efeito das operações de incorporação de sociedade é a passagem forçada dos acionistas da sociedade incorporada para a incorporadora (com exceção daqueles que exercerem seus direitos de retirada quando tal direito for aplicável) e a consequente unificação dos corpos sociais das duas sociedades. Há, assim, a modificação dos sistemas jurídicos particulares das sociedades incorporadora e incorporada de modo que, no contrato social da incorporadora, normalmente há acréscimo de posições jurídicas de sócios (sejam ações, quotas ou quinhões), enquanto na sociedade incorporada, há a extinção do contrato social.

Diz-se que normalmente há a unificação dos corpos sociais e acréscimo de posições jurídicas porque nem sempre esse efeito é encontrado em todas as operações de incorporação. Como veremos, há casos de incorporação que não geram acréscimo de posições jurídicas, como as incorporações de subsidiárias integrais, e casos em outros países que admitem que a contraprestação aos acionistas da sociedade incorporada não seja feita em ações.

Esse terceiro efeito das operações de incorporação é de extrema relevância para este trabalho, pois é dele que decorre a necessidade de determinar a relação de substituição de ações entre os acionistas da sociedade incorporadora e da sociedade incorporada, especificando quantas ações da incorporadora serão recebidas pelos acionistas da incorporada.

Feita essa breve análise do instituto da incorporação, passemos agora a estudar a sua natureza jurídica, sabendo que, apesar de muito já ter sido discutido no direito brasileiro e estrangeiro, ainda hoje, a questão não é pacífica.

$\mathrm{Na}$ Europa, a doutrina se dividia entre dois polos, o corporativo ou societário e o contratual. A vertente contratual seguida por FERRI e BRUNETTI entendia que, apesar da

25 Lei das S.A.: "Art. 219. Extingue-se a companhia: I - pelo encerramento da liquidação; II - pela incorporação ou fusão, e pela cisão com versão de todo o patrimônio em outras sociedades". Vide também N. EIZIRIK, A Lei das S/A comentada... cit., p. 245 e A. LAMY FILHO; J. L. BULHÕES PEDREIRA, A Lei das S.A. (pressupostos, elaboração, aplicação)... cit., p. 666. 
complexidade dos vários atos de natureza corporativa, a incorporação se traduzia em um contrato-base responsável por conduzir a operação. A incorporação não se realizaria, portanto, em virtude de um contrato de sociedade ou de um contrato de cessão de patrimônio, e sim em função de um negócio corporativo que é capaz de influenciar a estrutura interna dos entes envolvidos, mesmo que as manifestações de vontade social resultassem de um procedimento complexo e da colaboração de diversos órgãos societários. ${ }^{26} \mathrm{O}$ negócio de incorporação seria, portanto, um contrato necessariamente bilateral entre as sociedades envolvidas e decorrente das declarações de consentimento dos respectivos representantes legais das sociedades, ainda que tais manifestações decorressem de um processo que se desempenha separada, paralela e internamente em cada sociedade.

A corrente corporativa, de outro lado, cujo principal seguidor é URIA, entende que a teoria contratual não se presta a explicar os efeitos de ordem interna característicos da incorporação, quais sejam, a dissolução de algumas das sociedades incorporadas, a unificação dos patrimônios sociais e o agrupamento dos sócios em uma única sociedade. ${ }^{27}$

GARRIGUES, por sua vez, adota posição mista, defendendo que a incorporação se trata de uma relação jurídica complexa, pois ao mesmo tempo que não se encerra em um contrato entre duas sociedades, também necessita de um ato interno de caráter societário para se concretizar. Não obstante o negócio primordial ser um contrato, ocorre que, por se tratar de um contrato que necessariamente terá efeitos sobre a estrutura interna das sociedades, torna-se necessário que seja sancionado pelas assembleias gerais e siga os requisitos exigidos pela lei. ${ }^{28}$

$\mathrm{Na}$ doutrina brasileira, as incorporações foram inicialmente vistas sob o aspecto contratual, muito provavelmente em função da falta de previsão do instituto da incorporação no Brasil. Na vigência do Decreto n. 434, de 4 de julho de 1891, J. X. CARVALHO DE MENDONÇA aproximava as operações de incorporação a contratos de cessão em que uma sociedade se extingue enquanto outra que sobrevive alarga sua esfera de ação,

26 Cf. G. FERri, Le Società... cit., p. 688; A. BRUNETTI, Trattato del Diritto delle Società - Società per Azioni, Milano: Giuffrè, 1948, p. 631-632. Vide também W. BULGARELLI, Fusões, incorporações... cit., p. 79.

27 Cf. W. BulgarelLi, Fusões, incorporações... cit., p. 80.

28 Idem, ibidem, p. 81. 
acrescentando ao seu patrimônio os direitos e as obrigações da sociedade extinta. ${ }^{29}$ Defendia o autor que a ausência de regulação sobre a incorporação na legislação não significa sua proibição, mas sim que essa operação não passava de uma compra e venda ou uma cessão de estabelecimento, cujo preço seria pago em ações emitidas pela sociedade incorporadora. Para o autor, não havia necessidade de uma disciplina especial da operação já que os interessados teriam à disposição os contratos do direito comum e a incorporação não seria mais do que um modo cômodo, rápido e econômico para liquidação das sociedades. ${ }^{30}$

Já na vigência do Decreto-lei n. 2.627/1940, MIRANDA VALVERDE parece se filiar à corrente corporativa, salientando a importância dos atos internos das sociedades participantes em detrimento dos pactos ou das convenções firmados entre as sociedades relativos às bases das operações de incorporação. Para o autor, a incorporação pode ser entendida como uma operação de subscrição e integralização de capital em bens, com o consequente aumento de capital da incorporadora e extinção da incorporada, tratando-se, portanto, de um ato jurídico complexo. ${ }^{31}$ No mesmo sentido, W. FERREIRA e PONTES DE MIRANDA refutam a posição de que a incorporação seja mero contrato de cessão ou compra e venda de patrimônio, sobretudo porque não se tem pagamento de preço e tampouco se encontra o ânimo de comprar nas partes do negócio. ${ }^{32}$

BULGARELLI segue a orientação de GARRIGUES na doutrina estrangeira e entende que a incorporação se trata de uma relação complexa, na qual o aspecto societário e o contratual passam a se completar em busca do fim visado, que é a compenetração empresarial. Adota-se, assim, uma concepção mista segundo a qual tanto os contratos firmados pelas sociedades como os atos corporativos por elas praticados se completam numa verdadeira unidade, sendo ineficazes um sem os outros.

29 Tratado de direito comercial brasileiro, 7. ed., Rio de Janeiro/São Paulo: Freitas Bastos, 1963, v. 3, p. 67.

$30 \quad$ Idem, ibidem, p. 197-198.

31 Sociedade por Ações - comentários ao Decreto-lei n. 2.627, de 26 de setembro de 1940, 3. ed., Rio de Janeiro: Forense, 1959, v. 3, p. 81.

32 Cf. W. FERreIRA, Tratado de direito comercial, São Paulo: Saraiva, 1961, v. 4, p. 545; e F. C. PONTES DE MIRANDA, Tratado de direito privado, 3. ed., Rio de Janeiro: Borsoi, 1972, t. LI, p. 76. 
Impossível, portanto, dar como perfeita e acabada a incorporação apenas pelo cumprimento dos atos de natureza interna, esquecendo-se da importância do contrato de fusão para regular, pelo menos, três elementos básicos: a transmissão patrimonial, as participações dos sócios da incorporada na sociedade incorporadora e a extinção de pelo menos uma sociedade. Acordada a incorporação entre as sociedades, no momento em que as vontades sociais se cruzam, é evidente a formação de um contrato que determinará as bases segundo as quais se desenrolará a operação. Dessa maneira, embora não se possa desprezar a importância dos atos internos das sociedades, também não se pode transformálos em base da própria incorporação de modo que, em qualquer caso, a operação de incorporação se apresenta sob dois aspectos: um contratual, externo, que se passa entre as sociedades, e outro corporativo, interno em cada sociedade. ${ }^{33}$

É inegável, assim, a natureza contratual do instituto como ponto culminante do negócio de incorporação, por meio da qual os interesses das sociedades envolvidas, como sujeitos de direito, ajustam-se e se compõem em uma confluência de vontades. As decisões das assembleias gerais e da administração são meios para se atingir o fim visado, que é a realização da incorporação, funcionando como atos preparatórios com função instrumental impostas pela lei para tornar o negócio apto a produzir efeitos internos (acionistas) e externos (credores e terceiros).

Evidenciam-se, assim, as duas faces de um mesmo fenômeno. De um lado, temos a formação da vontade social das sociedades por meio de um procedimento complexo e, de outro, a contrariedade de interesses existentes que se encontram na formação do contrato que regulará as incorporações. Se nas operações de fusão propriamente ditas essa contrariedade de interesses pode não ser tão evidente, nas operações de incorporação ela aparece nítida e insofismável, pois enquanto uma sociedade busca se compenetrar na outra, transmitindo seu patrimônio e sócios, a outra visa à ampliação do seu quadro de sócios e do seu patrimônio. ${ }^{34}$

33 Cf. W. Bulgarelli, Fusões, incorporações... cit., p. 82. Reconhecendo também a natureza contratual das operações de incorporação, vide E. L. TEIXEIRA; J. A. TAVARES GUERREIRO, Das Sociedades Anônimas... cit., p. 659.

34 Cf. W. Bulgarelli, Fusões, incorporações... cit., p. 89. 
Nesse sentido, ASCARELLI inclui as fusões como uma subcategoria do contrato plurilateral, refutando a teoria do ato complexo para tais operações haja vista que existem partes com interesses contrastantes, demonstrando a clara natureza contratual do instituto. ${ }^{35}$ Segue o autor dizendo que a incorporação também pode ser considerada contrato plurilateral em vista dos seus elementos integrantes da mesma maneira que as fusões propriamente ditas e, com base na teoria do contrato plurilateral, os atos colegiais de cada sociedade - representando a fusão das manifestações de vontade de uma só parte, unificada como uma só vontade - concorreriam com a declaração de vontade da outra parte para integrar um contrato, no qual o conflito de interesses entre as partes aparece bastante nítido. $^{36-37}$

Em resumo, na trajetória do instituto, a incorporação nasceu sendo caracterizada como contrato obrigacional, evoluiu para o âmbito societário, dividindo-se entre os corporativistas e contratualistas, até que, por via do contrato plurilateral e suas atualizações, essa aparente dualidade é superada, assumindo o instituto a forma contratualsocietária.

Como contrato entre sociedades e inserida na disciplina societária, a incorporação utiliza-se, para sua efetivação, de instrumentos decorrentes da prática

35 Nas palavras do autor, “[h]á quem [...] encare também a fusão (no que diz respeito à constituição de nova sociedade) como ato complexo; mais exato parece-me, também neste caso, encarar como um contrato plurilateral pois há, inegavelmente, partes (nas várias sociedades) - e, possivelmente, mais de duas - com interesses contrastantes. Este contrato tem, afinal, natureza análoga à do contrato de constituição da sociedade, sendo ao contrário inexata a assimilação à venda; caracteriza-se, porém, pelo fato de ser concluído por sociedades que, simultaneamente, visam à própria extinção" (T. ASCARELLI, Problemas das Sociedades Anônimas e direito comparado, 2. ed., São Paulo: Saraiva, 1969, p. 266). T. ASCARElli, Problemas das Sociedades Anônimas... cit., p. 259-260.

37 F. C. PONTES DE MIRANDA, atentando também para o aspecto contratual e, inclusive, para a negociação das "bases da operação" como "pré-contrato", considera o negócio de incorporação como negócio jurídico bilateral ou plurilateral (Tratado de direito privado, t. LI, cit., p. 75 e 79). M. CARVALHOSA, por sua vez, também vê a incorporação como negócio plurilateral, de natureza voluntária, cuja causa é a intenção válida e eficaz dos sócios de integrarem seus patrimônios societários, realocando seus recursos patrimoniais e empresariais. As operações de incorporação de sociedades representam, ao mesmo tempo, ato constitutivo e desconstitutivo. Constitutivo porque resultam na agregação de patrimônios de duas sociedades em uma só e desconstitutivo porque representam também o desaparecimento da pessoa jurídica incorporada como efeito do negócio, com absorção de seu patrimônio pela incorporadora (Comentários à Lei de Sociedades Anônimas, v. 4, t. I cit., p. 233 e 274). Alguns autores, no entanto, comungam do entendimento de que as incorporações são atos complexos, como T. DE MIRANDA VALVERDE, como mencionamos acima. Outros autores, como E. F. DE PONTES, comentando as operações de incorporação de ações, definem como negócio bilateral entre duas companhias (Incorporação de ações no direito brasileiro, tese de doutorado apresentada à Faculdade de Direito da Universidade de São Paulo, 2013, p. 56). 
societária, porém não se reduz a eles, mesmo tendo sido, por diversas, vezes considerada como um dos modos de dissolução de sociedades, como meio prático de liquidação de sociedades ou, ainda, como uma simples subscrição de ações da sociedade incorporadora mediante aumento de capital com a integralização em bens.

As incorporações são negócios jurídicos contratuais típicos, ou nominados, próprios do direito societário e que têm a função de reorganizar as sociedades, ${ }^{38}$ sendo que quaisquer dessas aproximações, sem dúvida, simplificariam demais o instituto, focando apenas em um aspecto societário da operação e impedindo de vê-lo na sua devida amplitude. $^{39}$

Não é a incorporação, por exemplo, um simples contrato de subscrição para aumento de capital, pois sua complexidade lhe confere uma posição à parte e sua natureza típica o diferencia tanto dos contratos obrigacionais como dos demais institutos do direito societário. ${ }^{40}$ Além disso, os propósitos de tais operações são absolutamente distintos: no aumento de capital, o objetivo é justamente injetar recursos na companhia aumentando seu capital social, enquanto na incorporação, os objetivos são de ordem empresarial, espécie de ordem organizatória da sociedade, sendo o aumento de capital mera consequência da operação.

Se fossem realmente equivalentes a aumentos de capital, tais operações deveriam exigir a unanimidade de todos os sócios para a sua realização, dado que cada um deles deveria subscrever e integralizar as ações da sociedade incorporadora, dando vida a um contrato individual entre a sociedade que aumentou o capital e cada um dos novos subscritores. No entanto, as incorporações são aprovadas por maioria justamente porque se trata de negócios entre duas sociedades. Como veremos no item 1.1.2 abaixo, quem subscreve o aumento de capital nas incorporações é a própria diretoria e nãos os acionistas, por força do que estabelece o $§ 2 .^{\circ}$ do art. 227 da Lei das S.A. Além disso, se fosse equivalente a um aumento de capital, todos os acionistas da sociedade incorporadora deveriam ter direito de preferência na subscrição e estaria impossibilitada a existência do

\footnotetext{
38 Cf. A. LAmy Filho; J. L. Bulhões PedReIRA (Coord.), Direito das companhias, v. 2, cit., p. 1737.

39 Cf. W. BUlgarelLi, Fusões, incorporações... cit., p. 41.

$40 \quad$ Idem, ibidem, p. 41.
} 
direito de recesso na sociedade incorporada. Daí se vê, portanto, que a subscrição de ações verificada nas operações de incorporação não corresponde à subscrição comum. ${ }^{41}$

Além disso, caracterizar a operação de incorporação como simples aumento de capital afetaria a unidade dogmática do instituto, pois separaria substancialmente a incorporação da fusão, a qual, sob essa caracterização simplista, seria equivalente ao contrato de constituição de sociedade. Essa posição, como sabemos, não é correta, pois mesmo quando o instituto da fusão tem um tratamento legal específico, como é o caso do Brasil, ele se mantém íntegro em seus elementos constitutivos já que certas características diferenciadoras da fusão e da incorporação são de natureza secundária e não abalam a unidade do instituto. ${ }^{42}$

Ao concentrar em si um novo patrimônio e um novo grupo associativo, a sociedade incorporante não recebe uma simples adesão de novos sócios com a consequente subscrição de ações em bens. Mais do que isso, a transposição do patrimônio da incorporada e de um grupo de sócios abala de modo único as estruturas das sociedades e incide sobre os direitos dos sócios e dos credores, afetando os terceiros que mantinham relações com as sociedades envolvidas. A característica dos negócios de incorporação não é a de criar um vínculo jurídico entre as sociedades e terceiros ou mesmo entre as próprias sociedades, e sim de determinar uma nova estrutura interna dos entes que participam da operação. A particularidade de tais negócios consiste, portanto, na continuidade do vínculo social de determinada sociedade em um organismo social diverso. ${ }^{43}$

Vê-se, portanto, que as incorporações têm feições complexas, sendo operações nas quais o aspecto societário e o contratual passam a se completar em busca de um fim e que não se esgotam em soluções simplistas que as reduzem a mera subscrição de ações,

41 Cf. W. BULGaRELli, Fusões, incorporações... cit., p. 95.

42 Nesse sentido, vide A. LAMY FILHO; J. L. BUlHÕES PEDREIRA (Coord.), Direito das companhias, v. 2, cit., p. 1745-1746; W. BULGARELl, Fusões, incorporações... cit., p. 41; M. M. GUIRÃO, Fusión de Sociedades Mercantiles, Madrid: Editorial Revista de Derecho Privado, 1953, p. 90 e ss. Tanto é assim que nem consideramos o aumento de capital da sociedade incorporadora como condição essencial para que haja a incorporação nos casos de incorporações de subsidiárias integrais, companhias deficitárias ou companhias com ativo e passivo equivalentes. Como se vê, a incorporação visa à concentração empresarial, mas não necessariamente a um crescimento ou expansão da incorporante que implicaria, necessariamente, um aumento de capital. Nesse sentido, a doutrina se esforça para demonstrar os motivos que impelem as sociedades a se concentrarem, sejam eles para eliminar concorrentes, fazer uso de novas técnicas, para economias fiscais etc. (cf. W. BULGARELl, Fusões, incorporações... cit., p. 42). 
aumento de capital, alteração estatutária ou dissolução sem liquidação, pois cada um desses aspectos, embora integrantes das incorporações, não esgota completamente o instituto, mas sempre se soma aos demais atos. Tais atos demonstram apenas o aspecto da incorporação como uma legítima operação societária, isto é, um procedimento negocial composto de uma sequência de atos jurídicos que seguem determinada ordem necessária, dirigidos à obtenção de um resultado jurídico final e no qual cada ato pressupõe o precedente e prepara o subsequente. Cada um de tais atos, no entanto, não engloba a real dimensão do instituto e sua verdadeira natureza jurídica.

Outra questão também de interesse para este trabalho se refere à caracterização dos pactos de fusão e sua regulamentação legal. A própria construção jurídica da fusão parte da suposição da existência prévia desses acordos como demonstra, por exemplo, a nossa legislação desde 1940 quando falava nas "bases da operação" que deveriam ser acordadas e posteriormente aprovadas pelas assembleias. Essas bases da operação, evidentemente, não poderiam existir senão em decorrência da existência de um acordo prévio entre as sociedades envolvidas.

Primeiramente, cabe distinguir o acordo prévio e o contrato de fusão ou incorporação do ponto de vista terminológico. Os pactos de fusão são os acordos prévios firmados pelos representantes das sociedades e sujeitos ainda à aprovação das assembleias gerais, os quais são essenciais para algumas legislações que fazem expressa distinção entre o compromisso prévio de fusão e o contrato de fusão. ${ }^{44}$ Por essa razão, sua natureza jurídica ainda é bastante controvertida, sendo ora considerados como mero projeto sem eficácia jurídica, ora como contrato verdadeiro, ora ainda como um pré-contrato ou convênio preparatório. ${ }^{45}$

Já o contrato de fusão ou incorporação em si é definitivo e decorre da manifestação de vontade das sociedades na forma prescrita pela lei. Nos contratos de incorporação, há dois tipos de cláusulas: as cláusulas básicas, indispensáveis e inderrogáveis, que tratam sobre a transmissão do patrimônio, a extinção da incorporada e a obrigação de haver entrega de ações aos acionistas da sociedade extinta, e as cláusulas

44 Como a legislação argentina por disposição do art. 83 da Ley 19.550.

45 Cf. W. Bulgarelli, Fusões, incorporações... cit., p. 84. 
variáveis ou contingentes, que conterão tudo o mais que for de interesse das sociedades. Nessas últimas cláusulas é que se incluem as especificidades dos negócios, como, por exemplo, a solução econômica para a avaliação dos patrimônios, a relação de substituição de ações e as modificações estatutárias necessárias, e é justamente nessas cláusulas que podem ocorrer as distorções em favor dos controladores das sociedades. ${ }^{46}$

Dessa maneira, tem-se, de um lado, o chamado pacto de fusão, que em geral é prévio, celebrado pelos representantes de cada sociedade e sujeitos ainda à aprovação das assembleias gerais e, de outro, o contrato definitivo, que se forma após a manifestação de vontade das sociedades individualmente na forma prescrita na lei. Nas legislações em que não há expressa diferenciação entre o pacto prévio de fusão e o contrato de fusão, o conteúdo deste é, muitas vezes, equivalente ao daquele.

Na lei brasileira, desde a edição da atual Lei das S.A., exige-se a aprovação do protocolo de incorporação, o qual deverá conter as condições da incorporação negociadas em acordo prévio das sociedades. É, portanto, no protocolo de incorporação que se dá o consenso entre as sociedades para os termos da operação ou, como dispunha o Decreto-lei n. 2.627/1940 antes da existência da figura do protocolo, sobre as "bases da operação", incluindo a determinação da relação de substituição de ações.

A natureza jurídica do protocolo é, como se viu, controversa, tendo diversos autores se debatido no esforço de qualificá-lo. Entre os diferentes entendimentos, há aqueles que o enxergam como uma proposta para a assembleia geral, ${ }^{47}$ pré-contrato $^{48}$ ou pactum de contrahendo ${ }^{49}$ ou ainda convenção de natureza pré-contratual que manifesta e vincula as sociedades envolvidas no processo de incorporação por meio dos órgãos de administração das sociedades envolvidas. ${ }^{50}$ À parte todas as discussões históricas sobre a

46 Cf. W. BULGARELLI, Fusões, incorporações... cit., p. 84.

47 A. LAMY Filho; J. L. Bulhões PedREIRA (Coord.), Direito das companhias, v. 2, cit., p. 1757; e N. EIZIRIK, A Lei das S/A comentada cit., p. 222 e 232.

48 Cf. E. L. TeIXeIra; J. A. TAVAres Guerreiro, Das Sociedades Anônimas... cit., p. 660.

49 W. BUlgarelli, Fusões, incorporações... cit., p. 208; e F. C. PONTES DE MIRANDA, Tratado de direito privado, t. LI, cit., p. 75.

50 M. Carvalhosa, Comentários à Lei de Sociedades Anônimas, v. 4, t. I cit., p. 243. Para o autor, o protocolo tem como efeito direto a obrigação de fazer cumprir o que foi nele pactuado. Discordamos nesse ponto do referido autor, pois entendemos que a companhia somente pode se obrigar em matéria de incorporação por deliberação da assembleia geral, de modo que enquanto não aprovado por todas as assembleias não é contrato preliminar, mas apenas proposta de negócio jurídico. 
natureza do protocolo, hoje se entende que o protocolo é uma proposta de negócio jurídico que, independentemente da sua natureza, constitui um pacto entre os administradores das companhias envolvidas condicionado à aprovação da assembleia geral, que gera aos administradores, no máximo, a obrigação de apresentá-lo à assembleia geral. ${ }^{51}$ São, portanto, pactos prévios de fusão ou incorporação como decorrência de tratativas entre as sociedades, como ocorre em grande número de negociações mercantis para preparar o ajuste de vontades, ${ }^{52}$ os quais serão convolados, após as deliberações das assembleias, em contratos de fusão. ${ }^{53}$

Dessa maneira, o protocolo só vincula as sociedades envolvidas se for posteriormente aprovado pelos órgãos societários competentes que, no caso brasileiro, são as suas assembleias gerais, ${ }^{54}$ passando então a representar uma proposta de contratar à outra sociedade sujeita às normas do Código Civil sobre formação dos contratos (arts. 427 a 435$).{ }^{55}$

Como se viu acima, tanto a incorporação como o protocolo de incorporação, posteriormente convertido no contrato de fusão, têm natureza contratual, o que significa dizer que decorre do ajuste de vontades entre sociedades que negociam os seus termos conforme seu melhor entendimento e dentro de uma margem discricionária sobre a conveniência dos termos da operação. O maior problema, e ponto de extrema importância para este trabalho, é que não se regulamentaram suficientemente tais acordos prévios, principalmente o ajuste da relação de troca de ações entre as companhias. A explicação para esse fato parece ser a maior importância dada aos atos de natureza corporativa interna, justificando o aparente maior descaso da legislação para a chamada fase preparatória das incorporações, que, por se encontrar no âmbito meramente contratual, não encontra guarida no campo societário estrito e nas disciplinas da ordem corporativa. ${ }^{56}$ Os acordos de fusão

51 W. BUlgarelli, Fusões, incorporações... cit., p. 212; e N. EIZIRIK, A Lei das S/A comentada... cit., p. 222 e 247.

52 Cf. W. BULGARELl, Fusões, incorporações... cit., p. 45.

53 Idem, ibidem, p. 44.

54 Cf. A. LAmy Filho; J. L. Bulhões Pedreira (Coord.), Direito das companhias, v. 2, cit., p. 1746.

55 Cf. N. EIZIRIK, A Lei das S/A comentada... cit., p. 222 e A. LAMY FILHO; J. L. BUlHÕES PEDREIRA (Coord.), Direito das companhias, v. 2, cit., p. 1758.

56 Cf. W. BUlgarelli, Fusões, incorporações... cit., p. 83. 
são, portanto, deixados ao arbítrio das partes com base na ampla liberdade contratual, o que tem sido alvo de críticas por possibilitar abusos e fraudes como veremos adiante. ${ }^{57}$

\subsubsection{Procedimento de Incorporação para Sociedades Anônimas}

Após termos examinado brevemente a natureza jurídica das incorporações de sociedades, passemos a uma análise do procedimento pelo qual se concluem tais operações. Basicamente, as incorporações de sociedade se dividem em três fases sucessivas, semelhantes tanto no direito pátrio como no direito comparado, ${ }^{58}$ nas quais são praticados atos ora no interior das sociedades, ora entre as sociedades envolvidas na incorporação.

A primeira fase é a preparatória da negociação, na qual as bases da operação e as principais condições do negócio são debatidas e negociadas, para serem posteriormente definidas e consolidadas no projeto ou protocolo de incorporação. ${ }^{59} \mathrm{O}$ protocolo é um documento no qual são descritas as características essenciais da operação, elaborado e firmado geralmente pelos órgãos de administração ou representantes das sociedades ${ }^{60}$ uma vez que tais órgãos têm mais conhecimento e expertise sobre os negócios e atividades da sociedade do que os acionistas, além de terem formação e experiência para esse tipo de operação. ${ }^{61}$ Além disso, operações propostas pelos administradores são consideradas mais

57 Cf. W. BUlgarelli, Fusões, incorporações... cit., p. 83. Vide também G. BAUDEU; G. BELLARGENT "la phase de réalisation de la fusion est désormais minutieusement réglementée par le textes, alors que la phase préparatoire est encore 'libre'. La phase de réalisation est officiele par opposition à la phase préparatoire qui est officieuse, voire secret" (Fusion de sociétés, Fascicule 164 C, Paris: Librairies techniques, 1970, p. 3).

58 Cf. F. GAlgano, Diritto Commerciale... cit., p. 500; e A. LAMY FilHo; J. L. BUlhões PedREIRA (Coord.), Direito das companhias, v. 2, cit., p. 1746-1747.

59 Como se percebe, a atuação dos representantes das sociedades acontece desde antes da celebração do protocolo, pois esse não é celebrado sem a existência de negociações prévias. Nessa fase, pode haver, inclusive, a elaboração de outros instrumentos, como memorandos de entendimentos, ou a realização de outros procedimentos, como auditorias nas sociedades envolvidas. Essa fase é geralmente sigilosa, na qual predominam os aspectos negociais sobre os jurídicos dada a ausência de regulação específica para esse propósito.

60 Nesse sentido, vide o art. 224 da Lei das S.A. Na legislação estrangeira, seguindo as disposições do arts. 5. ${ }^{\circ}$ (1) e 9. ${ }^{\circ}$ da Diretiva 2011/35, vide (i) art. 98. ${ }^{\circ}-1$ do Código das Sociedades Comerciais de Portugal; (ii) art. 30-1 da Ley 3/2009 da Espanha; (iii) $§ 905$ (1) do Companies Act 2006 do Reino Unido; e (iv) $\S$ 251(b) da DGCL em Delaware.

61 Cf. C. TOMAZELla, Proteção de acionistas... cit., p. 34. 
coerentes e alinhadas com as estratégias e políticas comerciais das sociedades e, portanto, mais aptas a atenderem ao interesse social. ${ }^{62}$

Embora não seja tão usual, os sócios das sociedades interessadas na operação também podem negociar os termos do protocolo. Não obstante haver certa controvérsia sobre essa possibilidade, havendo autores que entendem que apenas os administradores das sociedades anônimas estão encarregados de negociar os termos do protocolo, acreditamos ser possível que essa negociação seja conduzida pelos sócios, já que tais sócios também podem propor e decidir sobre operações que estejam em linha com o interesse social das suas sociedades, notadamente o sócio controlador. ${ }^{63}$

Também nessa fase costuma-se exigir a preparação de outros documentos necessários para conferir aos acionistas e terceiros conhecimento sobre os termos da operação. Entre tais documentos, há o relatório em que se expõe a justificativa para a operação, pareceres elaborados por terceiros sobre os termos da operação, bem como

62 Cf. L. A. BeBChuK, The Case for Increasing Shareholder Power, Harvard Law Review, v. 118, n. 3, p. 882 .

63 M. CARVAlHOSA entende que, por ser o protocolo um documento técnico, deve ser necessariamente elaborado pelos órgãos da administração da companhia ou pelos sócios-gerentes das sociedades de pessoas. Para o autor, quando o art. 224 da Lei das S.A. fala em "sócios das sociedades interessadas", refere-se às sociedades limitadas ou em nome coletivo, nas quais todos os sócios são também gerentes, pois não se pode conceber que um sócio não gerente possa elaborar e firmar protocolo reorganizativo (Comentários à Lei de Sociedades Anônimas, v. 4, t. I cit., p. 248). Nesse mesmo sentido, P. C. ARAGÃO; M. M. MAVIGNIER DE LIMA, Incorporação de controlada: a disciplina do art. 264 da Lei 6.404/76, in: E. PERIN JÚNIOR; D. KALANSKY; L. PEYSER (Org.), Direito empresarial: aspectos atuais de direito empresarial brasileiro e comparado, São Paulo: Método, 2005, p. 347; e A. DE A. GONÇALVES NETO, A fusão, a incorporação e a cisão na lei de sociedade por ações... cit., p. 77. Não concordamos com esse ponto de vista, pois seria vedação que não decorre do texto da lei. Ademais, nas operações em que a sociedade tem acionista controlador, é razoável a possibilidade de que esse negocie e firme o protocolo e, ainda que a sociedade não tenha acionista controlador, não há por que vedar que o protocolo seja firmado por um sócio para posterior submissão à assembleia (nesse sentido vide A. LAMY FILHO; J. L. BUlHÕES PEDREIRA (Coord.), Direito das companhias, v. 2, cit., p. 1756; N. EIZIRIK, A Lei das S/A comentada... cit., p. 233 e E. VALLADÃO A. e N. FRANÇA, Temas de direito societário... cit., p. 360). C. TOMAZELLA defende que o protocolo poderia ser negociado e elaborado pelo sócio controlador apenas, pois ele não estaria em desvantagem informacional com os administradores e teria incentivos econômicos para empenhar tempo e recursos para promover a análise da situação das sociedades interessadas e negociar os termos da operação. Além disso, a regulamentação da Lei das S.A. e a da CVM reconhecem a influência do controlador e o sujeitam a regras específicas de responsabilidade, conforme art. 117 da Lei das S.A. e art. 15 da ICVM n. 319/1999 (Proteção de acionistas... cit., p. 3943). Na legislação estrangeira, países como Espanha, França, Alemanha e Reino Unido permitem que os acionistas aprovem operações de incorporação sem o apoio da administração, podendo também sugerir modificações ao projeto, mesmo que isso implique o retorno da administração às negociações. Delaware, por sua vez, tem a posição mais restrita, segundo a qual os acionistas não teriam poderes para elaborar uma proposta de incorporação, solicitar uma modificação ao protocolo apresentado ou mesmo exigir que a administração negocie uma operação de incorporação (vide S. M. BAINBRIDGE, Mergers and Acquisitions, 3. ed., New York: Foundation Press, 2012, p. 57; e C. TOMAZELlA, Proteção de acionistas... cit., p. 35-36). 
outros documentos que possam ser necessários, como, por exemplo, as demonstrações financeiras das sociedades.

Nesse sentido, os arts. 224 e 225 da Lei das S.A. exigem que os órgãos da administração ou os sócios de cada uma das sociedades interessadas na operação redijam o protocolo com os termos da operação e elaborem a justificação, no qual serão expostos os motivos que recomendam a operação.

Ainda nessa primeira fase é que se costuma proceder à contratação dos peritos $^{64}$ que avaliarão o patrimônio líquido da incorporada, nos termos exigidos pelo art. 226 da Lei das S.A., ainda que essa contratação fique sujeita à posterior aprovação da assembleia geral da incorporadora.

A primeira fase encerra-se, portanto, com a divulgação dos termos da operação proposta aos acionistas e a convocação da assembleia geral que deverá aprovar a operação em cada uma das sociedades. Ao convocar os acionistas para deliberar sobre a operação de incorporação, a administração das companhias envolvidas deve dar acesso a todos os documentos que embasaram a elaboração do protocolo e da justificação.

A segunda fase é a de aprovação do protocolo e da justificação da operação pelas assembleias gerais de cada uma das sociedades, sendo os acionistas os protagonistas dessa etapa. A assembleia geral é livre para aprovar ou recusar o protocolo, por entender que está incompleto ou insatisfatório, ou que a incorporação não atende ao interesse social, podendo também a assembleia determinar alterações ou correções ao protocolo. ${ }^{65}$

Nos termos do art. 227 da Lei das S.A., exige-se que sejam realizadas assembleias gerais tanto pela sociedade incorporadora quanto pela sociedade incorporada, sendo que, na sociedade incorporada, a operação deve ser aprovada por acionistas que representem metade, no mínimo, das ações com direito de voto (conforme art. 136, IV, da Lei das S.A.), enquanto na incorporadora vale a regra geral de aprovação por maioria simples. A princípio, nas operações de incorporação ocorreriam três assembleias: (i) uma

\footnotetext{
64 Por peritos entenda-se a contratação de três peritos ou de empresa especializada, conforme os termos exigidos pela Lei das S.A.

65 Cf. N. EIZIRIK, A Lei das S/A comentada... cit., p. 248.
} 
primeira assembleia da incorporadora, para aprovar o protocolo e nomear os peritos que deverão avaliar o patrimônio líquido da incorporada; (ii) uma assembleia da incorporada, para aprovar o protocolo e autorizar os administradores a praticar os atos necessários à realização da operação, inclusive a subscrição do aumento de capital da incorporadora; e (iii) uma segunda assembleia da incorporadora, para aprovar o laudo de avaliação preparado pelos peritos e declarar concluída a operação, mediante versão do patrimônio líquido da sociedade incorporada. ${ }^{66} \mathrm{Na}$ prática, sabe-se que as operações de incorporação realizam-se com apenas uma assembleia de cada companhia, já que a incorporadora, geralmente, realiza apenas uma assembleia após a elaboração do laudo, na qual aprova o protocolo, ratifica a escolha dos peritos, delibera sobre o laudo e declara concluída a operação. ${ }^{67-68}$

Nessa segunda fase ocorre também a aprovação da operação pela assembleia dos debenturistas, nos termos do art. 231 da Lei das S.A., caso a sociedade incorporada

66 M. CARVAlHosa defende que, embora não haja expressa menção na lei, a assembleia geral da incorporada também deve aprovar o laudo de avaliação do seu patrimônio conforme previsto nos $\S \S 2$. e 3..$^{\circ}$ do art. 8. $^{\circ}$ da Lei das S.A., até mesmo para aprovar eventual subscrição por valor menor do que o seu patrimônio avaliado (Comentários à Lei de Sociedades Anônimas, v. 4, t. I, cit., p. 278-279). Em sentido contrário, F. KONDER COMPARATO entende que cabe aos acionistas da incorporada apenas aceitar ou não a avaliação de seu patrimônio, mas nunca aprová-la porque, obviamente, o subscritor não pode aprovar o laudo de avaliação dos bens com que concorrer para formação do capital social (Novos ensaios e pareceres de direito empresarial, Rio de Janeiro: Forense, 1981, p. 207).

67 Nas operações entre sociedades sob controle comum, os acionistas ratificam ainda a escolha do avaliador para emissão do laudo exigido pelo art. 264 da Lei das S.A. e, nas companhias em que o direito de recesso se dá por valor econômico, ratificam o avaliador que emitirá tal laudo.

68 N. EIZIRIK entende, inclusive, que nas companhias abertas, não só é possível como recomendável a realização de apenas uma assembleia geral, pois, como a realização do laudo de avaliação pode demandar certo tempo, poderia haver perturbação na cotação das ações a divulgação da aprovação do protocolo na primeira assembleia e a conclusão da operação algum tempo depois, até que fosse concluído o laudo (A Lei das S/A comentada... cit., p. 248-249). E. F. DE PONTES, por outro lado, é absolutamente contrário à acumulação de decisões em apenas uma assembleia e sugere, inclusive, a separação entre assembleias distintas para aprovação da justificativa e do protocolo das operações, dado que a justificativa seria pressuposto e condição para que as administrações das companhias firmassem o protocolo. Segundo o autor, a aclamada simplificação do procedimento de incorporação trazido pela Lei das S.A. diante do confuso procedimento do Decreto-lei n. 2.627/1940 acabou, na verdade, condicionando a operação à aprovação do protocolo apenas, nos termos dos $\S \S 1 .^{\circ}$ e $2 .^{\circ}$ do art. 227 da Lei das S.A., nada falando sobre a justificação ou sobre as "bases da operação" como havia na lei anterior. Ao simplificar, portanto, a Lei das S.A. teria, na verdade, reduzido o procedimento de modo prejudicial aos minoritários e de maneira que permite atos de autoritarismo societário em prejuízo do debate em assembleias, sobretudo da justificação. Por fim, o autor rebate ainda o posicionamento de $\mathrm{N}$. EIZIRIK acima argumentando que o problema da perturbação da cotação das ações existe em outros casos do mercado de capitais (como ofertas públicas de aquisição) e, nem por isso, o procedimento de tais ofertas foi revisto, de modo que o correto seria sopesar se os benefícios advindos de um processo de incorporação mais lento, com decisões mais informadas, não compensaria o risco de perturbação na cotação das ações (Incorporação de ações no direito brasileiro... cit., p. 36-40). 
seja emissora de debêntures em circulação e não seja assegurado aos debenturistas o direito de resgatar as debêntures de que forem titulares.

Por fim, também nesse momento ocorre o exercício do direito de recesso pelos acionistas que não concordam com a realização da operação de incorporação nos termos apresentados, os quais terão suas ações reembolsadas, conforme estabelece o art. 230 da Lei das S.A.

Aprovada a operação pelas assembleias e formado o negócio de incorporação entre as sociedades, a terceira fase é a de implementação da operação, mediante aumento de capital da incorporadora integralizado com o patrimônio da incorporada, emissão de ações da incorporadora, subscrição e entrega de tais ações aos acionistas da incorporada em substituição às ações da sociedade incorporada que antes detinham. Com esse intuito, o $\S 2 .^{\circ}$ do art. 223 da Lei das S.A. prevê que os acionistas das sociedades incorporadas receberão, diretamente da companhia emissora, as ações que lhes couberem. Além disso, há o registro e a publicação dos documentos relacionados à incorporação pela administração da incorporadora, conforme o § 3. ${ }^{\circ}$ do art. 227 da Lei das S.A.

Importante notar que a subscrição e a integralização do capital não são realizadas pelos futuros acionistas, e sim pelos administradores da própria sociedade cujo patrimônio líquido é vertido. Como abordado no item acima, o negócio de incorporação se dá entre duas sociedades, de modo que são elas as partes. Os acionistas, embora possam ter interesse jurídico no processo de formação da vontade societária, não caracterizam tecnicamente um polo da relação jurídica principal entre as companhias. ${ }^{69}$

Já desde a lei de 1940, o que se verifica é a outorga de poderes aos administradores para a prática de atos de natureza corporativa necessários para levar a cabo a incorporação, inclusive a subscrição em bens decorrente do aumento de capital da sociedade incorporadora. Dessa maneira, os administradores agem como órgãos da

69 Vide E. F. DE PONTES, Incorporação de ações no direito brasileiro... cit., p. 55. Conforme o autor, as partes efetivas no negócio são as sociedades, mesmo que suas vontades expressas no protocolo se formem no âmbito de suas assembleias, em que os acionistas figuram como partes. São eles, portanto, partes da deliberação em assembleia, mas não do negócio de incorporação, o qual se forma entre as sociedades pela exteriorização das respectivas vontades sociais expressas pelos órgãos presentativos de tais sociedades (a diretoria, no caso das sociedades anônimas). 
sociedade levando a efeito um ato de natureza eminentemente corporativa que é a subscrição das ações da incorporante. Para E. LACERDA TEIXEIRA, os administradores não fazem a subscrição em nome pessoal, mas em nome e por conta dos próprios acionistas da sociedade a ser incorporada ou da sociedade cujas ações serão incorporadas ${ }^{70}$ de quem tem poderes de representação ex lege independentemente da vontade de tais acionistas. ${ }^{71}$ Essa é, também, a posição defendida por FERRI, que entende que os sócios da sociedade incorporada não adquirem sua qualidade de sócios na incorporadora como terceiros, e sim como sócios da sociedade transmitente e pela continuação do vínculo social originário na nova sociedade, dado que a aquisição da qualidade de sócio decorre de um negócio entre as sociedades, e não em decorrência de estipulações em favor dos sócios contidas no negócio de incorporação. ${ }^{72}$ É verdade que, economicamente, a transmissão patrimonial se refere aos bens dos sócios da sociedade incorporada, mas, juridicamente, tais bens pertencem ainda à sociedade e são transmitidos por ela e não pelos sócios. ${ }^{73}$

Finalizando a operação de incorporação, há o pagamento de eventuais valores decorrentes de direito de recesso, alterações estatutárias pertinentes à realização das providências para averbação da transferência dos bens e direitos da sociedade incorporada, cabendo aos administradores da incorporadora cuidar de promover o arquivamento e a publicação dos atos da incorporação para que produzam efeitos perante terceiros (arts. 130, 134 e 289 da Lei das S.A.). Nos termos do art. 234 da Lei das S.A., a certidão, passada

70 Cf. W. BUlgarelli, Fusões, incorporações... cit., p. 87.

71 Cf. N. EIZIRIK, Incorporação de ações: aspectos polêmicos, in: W. J. WARDE JUNIOR, Fusão, cisão, incorporação e temas correlatos, São Paulo: Quartier Latin, 2009, p. 87. A. XAVIER define como mandato sem representação ex lege, figura pela qual uma pessoa atua em nome próprio, mas por conta de outrem, nos termos do art. 663 do Código Civil, ao contrário do que ocorre no mandato com representação, em que o mandatário atua em nome e por conta do mandante (Incorporação de ações: natureza jurídica e regime tributário, in: R. R. MONTEIRO de CASTRO; L. S. DE ARAGÃO (Coord.), Sociedade Anônima 30 anos da Lei 6.404/76, São Paulo: Quartier Latin, 2007, p. 130). No mesmo sentido, N. EIZIRIK, A Lei das S/A comentada ... cit., p. 401.

72 Nas palavras do autor: "Gli effetti caratteristici, che si producono in ordine alla posizioni dei soci e in ordine al patrimonio della società, non si ricollegano ad um atto di volontà dei soci o a um atto di dispozione del patrimonio sociale [...] ma sono la conseguenza del nuovo ordenamento che le società si sono date" (G. FERRI, Le Società... cit., p. 688). Diz também o autor "Di fatti la qualitá de socio nella socièta incorporante o nella socièta che resulta dalla fusione non è acquistata dai soci dele socièta transmittenti in quanto terzi nel contratto di fusione, ma in quanto soci dele socièta. L'aquisito della qualità di soci è cioè um effetto dela particolare natura del negozio posto in essere fra le socièta, e non anche l'effetto della stipulazione a favore dei soci contenutta nel negozio di fusione" apud W. BULGARELLI, Fusões, incorporações... cit., p. 88. Interessante notar que o título do art. $24-1$ da lei espanhola referente às fusões é intitulado "continuidade da participação", mostrando claramente a ideia de que os acionistas da incorporada devem estender o vínculo societário que tinham dentro da nova sociedade incorporadora.

73 Cf. W. Bulgarelli, Fusões, incorporações... cit., p. 88. 
pelo registro do comércio, da incorporação, é documento hábil para a averbação, nos registros públicos competentes, da sucessão, decorrente da operação, em bens, direitos e obrigações.

\subsection{Incorporação de Ações}

\subsubsection{Operação de Incorporação de Ações e Natureza Jurídica}

De acordo com o art. 252 da Lei das S.A., a incorporação de ações é operação pela qual uma sociedade brasileira incorpora ao seu patrimônio todas as ações do capital social de outra companhia para convertê-la em subsidiária integral. ${ }^{74}$ Assim, a operação de incorporação de ações é aquela em que, por decisão da maioria dos acionistas nas companhias nela envolvidas, ${ }^{75}$ todas as ações de uma delas são compulsoriamente transferidas em aumento de capital para a sociedade incorporadora, de modo que a companhia que tem suas ações incorporadas torna-se subsidiária integral da incorporadora, sem que ocorra a extinção de nenhuma das sociedades e sem que venha a ser cancelada nenhuma ação da companhia que teve as ações incorporadas. ${ }^{76}$

Se aprovada tal operação, os acionistas da sociedade cujas ações são incorporadas perdem a titularidade dessas ações e, em contrapartida, recebem ações de emissão da sociedade incorporadora, da qual passam a fazer parte. Dessa maneira, assim como na incorporação de sociedades, um dos efeitos da incorporação de ações é a passagem forçada dos acionistas da sociedade que tem suas ações incorporadas para a incorporadora (com exceção daqueles que exercerem seus direitos de retirada) de acordo com a relação de substituição de ações acordada entre as companhias.

74 Lei das S.A.: "Art. 252. A incorporação de todas as ações do capital social ao patrimônio de outra companhia brasileira, para convertê-la em subsidiária integral, será submetida à deliberação da assembleia geral das duas companhias mediante protocolo e justificação, nos termos dos artigos 224 e 225 ".

75 A maioria não pode ser inferior à metade dos votos correspondentes a todas as ações votantes da

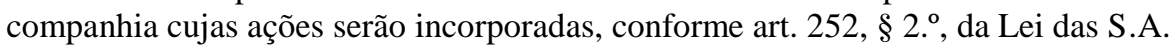

76 Nesse sentido, vide D. KALANSKY, Incorporação de ações: estudos de casos e precedentes, São Paulo: Saraiva, 2012, p. 37. 
Um segundo efeito da conclusão da incorporação de ações é a constituição de uma subsidiária integral de modo derivado,${ }^{77}$ cujo surgimento decorre justamente por conta da passagem de todos os acionistas que têm suas ações incorporadas para a sociedade incorporadora. A subsidiária integral, como se sabe, é aquela que tem por sócio uma só pessoa, física ou jurídica, cujo fim é exercer determinada atividade empresarial, sendo uma das exceções previstas na nossa legislação para a existência de uma sociedade unipessoal. ${ }^{78}$ Tais sociedades funcionam como instrumento para a descentralização administrativa mediante criação de um segmento de organização personificado e com patrimônio próprio que passa a exercer a atividade do seu objeto sob o controle do acionista único, mas com administração autônoma. Além disso, a constituição de patrimônio separado com responsabilidade limitada cria para o acionista uma unidade de risco econômico e financeiro distinto do restante da empresa, permitindo a combinação de um ou mais negócios em um mesmo grupo sem que haja contaminação dos riscos dos diferentes negócios. $^{79}$

Além disso, optar por operações de incorporação de ações com o consequente surgimento de uma subsidiária integral pode também trazer vantagens tributárias e regulatórias quando comparadas com as incorporações tradicionais de sociedades. Entre as vantagens tributárias, pode ser importante a manutenção de créditos ou prejuízos fiscais que poderão ser aproveitados se mantida a subsidiária integral ou ainda regimes tributários diferenciados e não transmissíveis por sucessão. Do ponto de vista regulatório, pode ser

77 A Lei das S.A. admite a constituição originária de uma subsidiária integral, nos termos do caput do art. 251, ou a sua constituição derivada por meio da aquisição de todas as ações de uma companhia ou por força da incorporação de ações, conforme o $\S 2 .^{\circ}$ do art. 251 da Lei das S.A.

78 As incorporações de ações surgem em um momento do direito societário em que havia grande receio em relação à sociedade unipessoal. Desde o ataque proferido por T. DE MIRANDA VALVERDE às sociedades unipessoais (Sociedade por ações..., v. 3, cit., p. 18), a doutrina vem aos poucos abrindo espaço para a existência e o reconhecimento da sociedade unipessoal, sendo a subsidiária integral importante marco nesse caminho. Outra exceção a essa regra são as sociedade que ficam reduzidas à unipessoalidade no curso da sua existência (denominada unipessoalidade superveniente ou provisória). Recentemente, a resistência que havia em reconhecer a personalização do empresário individual foi flexibilizada mediante a edição da Lei n. 12.441/2011 que instituiu a empresa individual de responsabilidade limitada (Eireli) passando a considerar como pessoa jurídica de direito privado as empresas individuais constituídas por uma única pessoa titular do capital social.

79 Cf. A. Lamy Filho; J. L. Bulhões Pedreira (Coord.), Direito das companhias, v. 2, cit., p. 19861987. 
vantajoso preservar certas autorizações essenciais que são muitas vezes dificilmente transferidas. ${ }^{80}$

Por fim, incorporações de ações podem ser também utilizadas como mecanismos para promover a concentração de minoritários dispersos em uma única sociedade holding ${ }^{81}$ ou, até mesmo, para adquirir o controle de outras companhias quando não se dispõe de caixa suficiente para promover a aquisição. ${ }^{82}$

Quanto à sua natureza jurídica, o instituto da incorporação de ações apresenta também seus desafios, que se iniciam pela infeliz escolha da expressão "incorporação de ações". A expressão incorporação de ações é bastante questionável, ainda mais quando todo o sistema documental e procedimental é emprestado das incorporações de sociedades, instituto com o qual não se confunde. Agrava-se a situação pelo fato de ser a incorporação de ações um instrumento único no direito comparado, pois, embora haja diversas aproximações com institutos estrangeiros, essas aproximações em geral confundem o processo, a forma e o procedimento que definem as incorporações de ações com operações de outra natureza. ${ }^{83-84}$

80 Vide D. KALANSKY, Incorporação de ações... cit., p. 43.

81 No direito societário moderno, a organização da empresa em diversas sociedades que pertencem a um grupo de fato ou de direito conectadas por uma estrutura complexa de controle e administração é cada dia mais comum. Nos processos de integração de companhias, mecanismos como a incorporação de ações são fundamentais para se atingir a integração necessária entre os grupos.

82 E. F. DE PONTES, Incorporação de ações no direito brasileiro... cit., p. 8.

83 Cf. A. LAMY FILHO; J. L. BUlHÕES PEDREIRA (Coord.), Direito das companhias, v. 2, cit., p. 1993; e E. F. DE PONTES, Incorporação de ações no direito brasileiro... cit., p. 5 e 15.

84 As legislações estrangeiras, sempre que cuidam da fusão ou incorporação, tratam de processos que resultam na extinção da sociedade incorporada. Algumas exceções a essa característica se encontram no direito português e alemão, onde se encontram institutos que de certa maneira se aproximam às incorporações de ações. No direito português, a aquisição potestativa regulada no art. 194 do Código dos Valores Mobiliários permite àquele que, na sequência do lançamento de oferta pública de aquisição geral tiver atingido ou ultrapassado $90 \%$ dos direitos de voto correspondentes ao capital social e $90 \%$ dos direitos de voto abrangidos pela oferta, nos três meses subsequentes, adquirir as ações remanescentes mediante contrapartida justa a ser paga aos minoritários. Embora muito mais próximo ao nosso resgate previsto no art. $4 .^{\circ}, \S 5^{\circ}$, da Lei das S.A., esse instituto assemelha-se também à incorporação de ações entre sociedade controladora e controlada, residindo a diferença no modo de pagamento: enquanto no direito brasileiro, o pagamento da incorporação de ações se dá pela entrega de ações, na aquisição potestativa o pagamento se dá em dinheiro. Na Alemanha, o instituto do Eingliederung, regulado pelos $\S \S 319-327$ da Aktiengesetz, permite a integração de duas sociedades, com a sobrevivência de ambas, sendo uma como subsidiária integral da outra, nos casos em que a sociedade controladora já possui pelo menos $95 \%$ das ações da companhia a ser a ela integrada mediante pagamento de compensação adequada aos minoritários em ações ou em dinheiro conforme permitido pelos $\S \S 327$ a-f. Trata-se de operação de concentração societária específica, razão pela qual está inserida na Aktiengesetz e não na Umwandlungsgesetz, e que pressupõe o controle e a titularidade de, no mínimo, 
Uma primeira gama de interpretações aproxima as incorporações de ações ao instituto das incorporações de sociedades. Nessa corrente enquadra-se, por exemplo, A. LAMY FILHO e J. L. BULHÕES PEDREIRA, que definem a incorporação de ações por meio de sua comparação com o instituto tradicional na incorporação de sociedades, identificando naquela mera derivação desta, diferenciando-se apenas quanto ao fato de que na incorporação de companhias há a extinção da companhia incorporada, ao passo que na incorporação de ações não. ${ }^{85}$ Também N. EIZIRIK utiliza o instituto da incorporação de

95\% do capital da sociedade a ser integrada. Dessa maneira, tal hipótese também se aproxima mais do nosso resgate de ações do que da incorporação de ações propriamente dita (vide, nesse sentido, E. F. DE PONTES, Incorporação de ações no direito brasileiro... cit., p. 23). No direito estadunidense, há as figuras do freeze out merger ou squeeze out merger com pagamento em ações ou dinheiro (nesse último caso, também conhecida como cash out merger) que se assemelham às incorporações de ações. No entanto, tais operações necessariamente nascem de uma relação prévia entre controlador e minoritários, o que não acontece necessariamente na incorporação de ações brasileira. Outras operações do direito estadunidense são assemelhadas às incorporações de ações, como as operações de share exchange. Nesse sentido, D. KALANSKY aproxima a figura da incorporação de ações à operação de share exchange (ou stock swap), segundo a qual, por decisão adotada por maioria dos votos de acionistas de ambas as companhias, os titulares de ações da incorporada recebem diretamente ações da incorporadora conforme relação de troca aprovada no plan of merger, de maneira compulsória, sem que ocorra a extinção de nenhuma das sociedades (cf. D. KALANSKY, Incorporação de ações... cit., p. 59-60; vide também R. SZTAJN, Fusão, incorporação e cisão... cit., p. 144). No entanto, a exatidão dessa aproximação é contestada por E. F. DE PONTES (Incorporação de ações no direito brasileiro... cit., p. 24) de acordo com quem as share exchanges também estão inseridas no contexto das freeze out mergers e das triangular transactions. Segundo o autor, existem contornos específicos que distanciam a stock exchange da incorporação de ações, como o aumento de capital obrigatório previsto no art. $252, \S 1$. $^{\circ}$, da Lei das S.A. e a possibilidade sob o direito estadunidense de se atribuir ações do controlador para o capital da subsidiária para efetivar a troca, o que é vedado pela nossa legislação (além de outras contraprestações que são admitidas). A principal diferença, no entanto, estaria na estrutura triangular das share exchanges, pois a maioria dessas operações se dá pela criação pela companhia adquirente de uma subsidiária integral que carrega em seu patrimônio o ativo que será dado em troca (sendo que tal ativo poderá ser representado por ações da sociedade adquirente). A subsidiária criada será então incorporada ao capital da empresa alvo ou vice-versa, funcionando como veículo para transformar a companhia alvo em subsidiária integral da adquirente. Essa estrutura triangular, envolvendo ações ou valores mobiliários já emitidos, em vez de um aumento de capital com ações novas, é uma das características principais dessa operação que a diferencia da incorporação de ações brasileira (cf. S. M. BAINBRIDGE, Mergers and Acquisitions... cit., p. 56-57). Segundo o autor, nossa operação de incorporação de ações pode se aproximar tanto das share exchange como das freeze out mergers dependendo do caso concreto e da finalidade da operação que se busca com as incorporações de ações (Incorporação de ações no direito brasileiro... cit., p. 24-25). N. EIZIRIK afirma que as incorporações de ações são instrumento jurídico adaptado da experiência prática do mercado norte-americano, aproximando-as a uma das modalidades de practical mergers, também chamadas às vezes de merger with shares, em que uma companhia adquire todas as ações de outra pagando o preço com suas ações (N. EIZIRIK, A Lei das S/A comentada... cit., p. 396). No entanto, as semelhanças com as incorporações de ações são quase nulas, pois nesses casos o que se verifica é uma verdadeira aquisição com pagamento em ações em tesouraria, não ocorrendo nesses casos decisões em assembleia ou relações de troca (cf. E. F. DE PONTES, Incorporação de ações no direito brasileiro... cit., p. 26). 
sociedades como instrumento para definir e estudar as incorporações de ações, apesar de reconhecer que essas se definem como institutos híbridos. ${ }^{86}$

Uma segunda corrente associa a incorporação de ações a uma espécie de aumento de capital com conferência de bens - no caso, as ações incorporadas - em troca de ações na sociedade incorporadora. ${ }^{87}$ Embora haja, sem dúvida, aproximações entre os dois processos, a incorporação de ações não se resume a um aumento de capital social integralizado em bens. De acordo com A. XAVIER, o processo de incorporação de ações não é equivalente à mera subscrição de aumento de capital da sociedade pelos acionistas da subsidiária, pois na incorporação de ações a deliberação é da assembleia geral, que aprova a incorporação por maioria qualificada impondo-a aos demais acionistas, e não de cada acionista individualmente. ${ }^{88}$

Assim como no caso das incorporações de sociedades, para serem comparadas a aumentos de capital, tais operações deveriam exigir a unanimidade de todos os sócios de modo que cada um realizasse o aumento de capital individualmente, mas não é esse o caso da incorporação de ações. Conforme estabelece o $§ 2 .^{\circ}$ do art. 252 da Lei das S.A., a diretoria é que deverá representar os acionistas de cada sociedade, independentemente de suas vontades. Aqui, quem subscreve o aumento de capital não são os acionistas, e sim a diretoria da sociedade cujas ações serão incorporadas, uma vez que o negócio se dá entre duas sociedades. ${ }^{89}$ Além disso, não há direito de preferência na subscrição para os acionistas da incorporadora.

86 N. EIZIRIK, A Lei das S/A comentada... cit., p. 396-397.

87 Vide FRAn MARTINS, Comentários à lei de sociedade anônima, v. 3, Rio de Janeiro: Forense, 1978, p. 306 (o autor aproxima ainda as incorporações de ações a um procedimento que pode ser visto de duas maneiras: ou como uma transferência de ações da sociedade incorporadora para os acionistas da incorporadora como pagamento pelas ações subscritas no aumento de capital ou como uma venda das ações da incorporada cujo pagamento se dará com ações da incorporadora que foram emitidas com o aumento de capital); E. L. TEIXEIRA; J. A. TAVARES GuERreIro, Das Sociedades Anônimas... cit., p. 727.

88 Segundo o autor, a lei, prescindindo da regra da unanimidade, abandonou a construção jurídica da figura do aumento de capital para optar por um contrato entre sociedades (A. XAVIER, Incorporação de ações: natureza jurídica e regime tributário... cit., p. 124-127).

89 Cf. A. XAVIER, ao dizer que na incorporação de ações o negócio se dá entre duas sociedades e o acionista não transfere bens ou direitos de nenhuma natureza, limitando-se de modo estático e passivo a ter seu patrimônio substituído por ações da sociedade incorporadora (Incorporação de ações: natureza jurídica e regime tributário... cit., 2007, p. 127-129). Nesse mesmo sentido, vide também S. C. NAVARRO COÊLHO ao dizer que na subscrição de ações por conferência de bens, além da prévia chamada de capital, ocorre a manifestação unitária do acionista que se torna parte na relação. $\mathrm{Na}$ 
CARVAlHOSA, por sua vez, entende que a incorporação de ações se resume a uma incorporação e alienação fictas, na qual o controlador da sociedade incorporadora aliena não apenas as suas ações, mas também as ações dos minoritários, em um negócio sui generis que lembra a expropriação do direito administrativo. ${ }^{90}$ Esse não parece ser o melhor entendimento, pois entendemos que a incorporação aqui quer dizer "incorporação de bens" a determinado patrimônio e não incorporação ficta de sociedade, sendo que não há nenhuma alienação de ações. ${ }^{91}$

Outros autores associam a incorporação de ações a um processo e, apesar de mencionarem o aumento de capital, ampliam a óptica de análise para enxergar uma natureza de processo no instituto como um meio de transferência compulsória de ações de emissão de uma companhia para a titularidade de outra companhia, dando unicidade ao instituto. ${ }^{92}$ São, portanto, institutos próprios do direito societário, estabelecidos em lei e com regulamentação própria, configurando-se como operações típicas de concentração empresarial que não se esgotam em soluções simplistas que as reduzem a mera subscrição de ações e aumento de capital. ${ }^{93}$

Esse posicionamento reflete, inclusive, as feições complexas das incorporações de ações, nas quais, assim como nas incorporações de sociedades, o aspecto societário e o contratual passam a se complementar com o intuito de concluir a operação visada. ${ }^{94}$

incorporação de ações, os sócios não praticam nenhum ato de alienação de suas ações, pois apenas as pessoas societárias envolvidas atuam. (Imposto sobre a renda e incorporação de ações da sociedade "Holding", Revista Dialética de Direito Tributário, n. 77, fev. 2002, p. 178-179). Também desse entendimento, M. CARVAlhosA; N. EIZIRIK, Estudos de direito empresarial, São Paulo: Saraiva, 2010, p. 88.

90 Comentários à Lei de Sociedades Anônimas, v. 4, t. II cit., p. 140.

91 Conforme A. LAMY Filho; J. L. BUlhões PedReIRA (Coord.), Direito das companhias, v. 2, cit., p. 1995; D. KALANSKY, Incorporação de ações... cit., p. 47; C. M. M. SCHLIECKMANN, Aspectos societários da incorporação de ações de controlada envolvendo companhia aberta, monografia apresentada ao Departamento de Direito da Pontifícia Universidade Católica do Rio de Janeiro para obtenção do título de Bacharel em Direito, disponível em: <http://www.maxwell.lambda.ele.pucrio.br/16767/16767.PDF>, acesso em: 7 ago. 2013, p. 23.

92 E. F. DE PONTES, Incorporação de ações no direito brasileiro... cit., p. 15; e L. L. CANTIDIANO, Incorporação de sociedades e incorporação de ações, in: R. R. M. DE CASTRO; L. A. N. DE MOURA AZEVEDo (Coord.), Poder de controle e outros temas de direito societário e mercado de capitais, São Paulo: Quartier Latin, 2010, p. 140.

93 Nesse sentido, vide D. KALANSKY, Incorporação de ações... cit., p. 52.

94 Vide nesse sentido C. M. M. SCHLIECKMANN, Aspectos societários da incorporação de ações... cit., p. 21-22. 
Dessa maneira, as incorporações de ações são também negócios jurídicos contratual-societários cujas partes são as sociedades envolvidas - e não os acionistas -, que têm por finalidade a integração de participação acionária por meio da agregação de todas as ações incorporadas no patrimônio da incorporadora. ${ }^{95}$ Assim como nas incorporações de sociedades, os acionistas das companhias envolvidas na operação participam nas assembleias que aprovarão a operação, mas não como partes do negócio de incorporação em si. Portanto, não são eles que praticam atos de disposição de suas ações para integralização de subscrição de capital na incorporadora, bem como a incorporadora não adquire tais ações por efeito de alienação individual por cada acionista que teve suas ações incorporadas. $^{96}$

Por fim, o protocolo de uma operação de incorporação de ações também tem natureza contratual, decorrendo do ajuste de vontades entre sociedades que negociam os seus termos, assim como ocorre com as operações de incorporação de sociedades.

\subsubsection{Procedimento de Incorporação de Ações para Sociedades Anônimas}

Apesar de terem efeitos distintos, a Lei das S.A. estende às incorporações de ações parte do procedimento adotado pela lei para regular as incorporações de sociedades no que tange à elaboração do protocolo e da justificação previstos nos arts. 224 e 225 da Lei das S.A., de modo que ambas as operações apresentam semelhanças procedimentais. ${ }^{97}$

Assim como na incorporação de sociedades, o procedimento de incorporação de ações divide-se em diferentes etapas. Na primeira delas, quando ocorre a definição das condições do negócio, os órgãos da administração ou os acionistas elaboram o protocolo com as condições do negócio nos termos do art. 224 da Lei das S.A. e elaboram a justificação conforme o art. 225 da Lei das S.A., submetendo, em seguida, tais documentos

Cf. M. Carvalhosa, Comentários à Lei de Sociedades Anônimas, v. 4, t. II, cit., p. 147.

Cf. A. LAMY FILHO; J. L. BUlHÕES PEDREIRA (Coord.), Direito das companhias, v. 2, cit., p. 1994.

Nesse sentido, N. EIZIRIK, A Lei das S/A comentada... cit., p. 398; e D. KALANSKY, Incorporação de ações... cit., p. 42. Nesse ponto, interessante a posição contrária de E. F. DE PONTES, para quem a Lei das S.A. não toma de empréstimo todo o processo de incorporação de sociedades para as incorporações de ações, mas apenas empresta o conteúdo do protocolo e da justificação previstos para as incorporações de sociedades. Assim, as incorporações de ações seguiriam procedimento próprio (Incorporação de ações no direito brasileiro... cit., p. 77). 
para as assembleias gerais das companhias de acordo com o art. 252 da Lei das S.A., juntamente com os demais documentos pertinentes.

Na fase seguinte, de formação do negócio, as assembleias gerais de ambas as sociedades deliberam sobre o negócio proposto e a aprovação do protocolo por ambas as companhias dá origem ao negócio jurídico de incorporação de ações, sendo que na assembleia geral da companhia cujas ações tiverem que ser incorporadas deverá haver aprovação de, no mínimo, metade do capital votante conforme o $§ 2 .^{\circ}$ do art. 252 da Lei das S.A.

Na assembleia da incorporadora deverá também ser autorizado o aumento de capital a ser integralizado com as ações que serão incorporadas e nomeados os peritos que deverão avaliá-las. Já na assembleia geral da companhia cujas ações houverem de ser incorporadas, se aprovada a operação, deverá haver autorização para que a diretoria subscreva o aumento de capital da sociedade incorporadora entregando as ações incorporadas em nome de seus acionistas.

Por fim, a assembleia geral da incorporadora deverá então avaliar e aprovar o laudo de avaliação das ações a serem incorporadas e declarar efetivada a operação, entregando ações de sua emissão aos acionistas que tiveram suas ações incorporadas.

Assim como nas incorporações de sociedades, nas operações de incorporação de ações também é possível que sejam feitas apenas duas assembleias gerais, uma da sociedade incorporadora e outra da sociedade cujas ações serão incorporadas.

Cabe, finalmente, analisar uma pequena peculiaridade no ato da subscrição quando se trata de operações de incorporação de ações. Nesses casos, a dissociação entre a autoria dos atos jurídicos e a produção dos seus efeitos é ainda maior do que nas incorporações de sociedades, pois enquanto nas incorporações de sociedades a sociedade incorporada subscreve o capital com bens próprios, na incorporação de ações a sociedade subscreve o capital não com bens próprios, mas com bens alheios (as ações dos seus acionistas). Na verdade, a permissão dada pela lei para que a sociedade atue em nome de seus sócios e afetando bens de seu patrimônio se explica porque tais bens (as ações) não 
são dotados de plena autonomia, e sim títulos representativos do próprio patrimônio da sociedade. $^{98}$

\subsection{Incorporação de Sociedades e Incorporação de Ações}

\subsubsection{Semelhanças e Diferenças}

Tanto as operações de incorporação como as incorporações de ações prestamse, fundamentalmente, para promover a concentração empresarial e a reorganização de empresas com o intuito de torná-las mais eficientes.

Embora sejam negócios distintos, ambas têm a função de unificar duas companhias e seus efeitos patrimoniais e societários são bastante semelhantes para os acionistas das sociedades envolvidas. Tanto em uma quanto em outra, a companhia incorporadora deve, a princípio, realizar um aumento de capital que será subscrito com a versão do patrimônio da incorporada ou com as ações de sua emissão de modo que os sócios da incorporada (ou da sociedade cujas ações são incorporadas) passam a ser acionistas da incorporadora ao receber ações desta em substituição às suas antigas ações, de acordo com a relação de substituição negociada. ${ }^{99}$

A propósito, vide voto do colegiado do Dir. Pedro Marcilio da CVM no Processo CVM n. RJ 2007/3453, j. 18.04.2007, em que se sustentou que "além da similitude dos dispositivos legais aplicáveis à incorporação de sociedades e à incorporação de ações, em ambos os casos os efeitos econômicos são os mesmos: a minoria acionária 'migra' da incorporada para a incorporadora e a incorporadora tem acesso a $100 \%$ da empresa exercida na sociedade incorporada". E continua ao dizer que "a disciplina jurídica da incorporação de ações é muito semelhante à disciplina jurídica da incorporação de sociedade (bem como os resultados econômicos, para o acionista de ambas as sociedades), sendo as duas únicas diferenças relevantes a sobrevivência da sociedade incorporada (embora sem qualquer acionista) e a conferência de direito de direito de retirada para os acionistas da incorporadora no caso da incorporação de ações". No mesmo sentido, a

98 Cf. A. XAVIER, Incorporação de ações: natureza jurídica e regime tributário... cit., p. 129-131.

99 Cf. N. EIZIRIK, A Lei das S/A comentada... cit., p. 242. 
Exposição de Motivos n. 196 de 24 de junho de 1976 da Lei das S.A. diz que a incorporação de ações é meio de tornar a companhia subsidiária integral, e equivale à incorporação de sociedade sem extinção da personalidade jurídica da incorporada. ${ }^{100}$

Outra semelhança entre as operações de incorporação de sociedades e incorporações de ações é que os acionistas da empresa incorporadora não têm direito de preferência na hipótese de aumento de capital social decorrente da incorporação, uma vez que seria inviável assegurá-lo a qualquer acionista que não os destinatários necessários da sociedade incorporada ou àqueles que têm suas ações incorporadas. ${ }^{101}$ Dessa maneira, o problema decorrente da diluição dos sócios da incorporadora pelo recebimento dos novos acionistas, bem como a questão da diluição de tais acionistas quando da sua migração para dentro da sociedade incorporadora, são questões que estão presentes em ambas as operações, o que explica também o estudo conjunto de tais institutos neste trabalho.

No entanto, embora tenham efeitos semelhantes, as operações de incorporação de sociedade e incorporação de ações não se confundem e são, por essa razão, analisadas de maneira dissociada unanimemente pela doutrina. A incorporação de sociedade, como vimos, aproxima-se muito mais a uma subespécie da fusão, enquanto a incorporação de ações pode ser considerada um processo de transferência compulsória de ações de emissão de uma companhia para a titularidade de outra companhia.

A primeira diferença fundamental entre as operações de incorporação de sociedades e incorporação de ações é que nas primeiras há a extinção da sociedade incorporada, enquanto na segunda a subsidiária integral mantém intacta sua personalidade jurídica e seu patrimônio, continuando responsável pela solução de todas as suas obrigações. ${ }^{102}$ Não há, assim, na incorporação de ações, transferência de patrimônio de uma sociedade para outra, mas da totalidade das ações de uma companhia para a outra,

100 Vide também M. CARVAlHOSA; N. EIZIRIK, Estudos de direito empresarial... cit., p. 90.

101 Nesse sentido, D. KALANSKY, Incorporação de ações... cit., p. 41. Ao regular as operações de incorporação, o $\S 2 .^{\circ}$ do art. 227 se refere à subscrição do aumento de capital da incorporadora pela incorporada, e não pelos acionistas da incorporadora ou da incorporada. É, logicamente, bastante evidente que o procedimento não poderia ser diferente, já que a possibilidade de os acionistas da sociedade incorporadora exercerem direito de preferência nos aumentos de capital decorrentes de incorporação inviabilizaria a integração na sociedade incorporadora dos acionistas da incorporada ou da sociedade cujas ações foram incorporadas. 
permanecendo a subsidiária integral como pessoa jurídica independente, sem que ocorra a sucessão de direito e obrigações entre as sociedades envolvidas. ${ }^{103} \mathrm{Na}$ incorporação de ações, portanto, a unificação se dá apenas do ponto de vista econômico e social, porque a companhia cujas ações são incorporadas continua a existir como subsidiária integral, sem que haja uma integração jurídica dos seus patrimônios. ${ }^{104}$

Outra diferença entre os dois institutos é que na incorporação de ações tanto os acionistas dissidentes da incorporadora como os acionistas da sociedade que têm suas ações incorporadas poderão se retirar da companhia mediante reembolso de suas ações (conforme o art. 252 da Lei das S.A.), enquanto na incorporação de sociedades apenas os acionistas da sociedade incorporada é que têm o direito de recesso (conforme os arts. $137 \mathrm{e}$ 136, IV, da Lei das S.A.). ${ }^{105}$ Cabe lembrar apenas que o direito de recesso dos acionistas não existe para as ações que têm liquidez e dispersão no mercado.

Por fim, embora diferentes, existe um ponto em comum entre as operações de incorporação de sociedades e as incorporações de ações. Em ambos os casos, os acionistas da companhia incorporada ou aqueles que têm suas ações incorporadas perdem a titularidade de suas ações para receber, em contrapartida, ações da incorporadora, de acordo precisamente com a relação de troca negociada entre as sociedades. ${ }^{106}$ Os debates sobre a relação de troca e questões envolvendo limites à sua negociação serão, portanto, os principais pontos de convergência entre as duas operações a serem aqui estudados. ${ }^{107}$

103 Cf. A. XAVIER, Incorporação de ações: natureza jurídica e regime tributário... cit., p. 122.

104 Cf. A. LAMY FILHO; J. L. BUlHÕes PEDREIRA (Coord.), Direito das companhias, v. 2, cit., p. 1993.

105 O motivo dessa diferenciação entre as operações de incorporação de sociedades e incorporação de empresas não é clara, já que os efeitos para os acionistas são muito semelhantes em ambas as operações. Por essa razão, muitos autores afirmam que essa distinção decorre de erro de revisão durante a discussão do projeto da Lei das S.A. (nesse sentido, vide A. LAMY FILHO; J. L. BULHÕES PEDREIRA (Coord.), Direito das companhias, v. 1, cit., p. 356; e D. KALANSKY, Incorporação de ações... cit., p. 40).

106 Cf. N. EIZIRIK, A Lei das S/A comentada... cit., p. 397; e M. CARVALHOSA e N. EIZIRIK que reconhecem que os efeitos para os acionistas são os mesmos em ambas operações (Estudos de direito empresarial... cit., p. 91).

107 Vide nesse sentido voto do Diretor Sergio Eduardo Weguelin Vieira no Processo CVM n. RJ 2007/3453, rel. Dir. Sergio Weguelin, j. 04.03.2008 em que diz que "[a]s relações de troca, os impedimentos de voto e tudo mais que pudesse se relacionar à legalidade da incorporação independem da forma escolhida [incorporação de sociedades ou incorporação de ações]”. Em sentido contrário, importante notar a opinião de E. F. DE PONTES segundo quem o modelo de negócios da incorporação de sociedades é completamente distinto do modelo de negócios da incorporação de ações e, portanto, ainda que haja debate sobre a relação de troca e justiça da operação em ambas as operações, as premissas que levam duas empresas (ou conglomerados) a optar pela via da incorporação das ações em vez da 


\subsubsection{Importância das Operações de Incorporação}

As operações de incorporação são, na prática negocial, um dos institutos jurídicos mais utilizados nos processos de concentração empresarial. ${ }^{108}$

Tais processos de concentração e reorganização empresarial, por sua vez, são típicos do capitalismo moderno e cada vez mais evidentes. Na busca por empresas mais eficientes, as concentrações empresariais justificam-se, basicamente, por três fatores essenciais: (i) economias de escala possibilitadas pela concentração, que reduzem os custos de distribuição e produção, (ii) necessidade de diversificação da produção e dos mercados atingidos, reduzindo riscos inerentes a uma atividade monoprodutora, e (iii) facilitação da produção de inovação tecnológica em unidades integradas de produção e com maior acesso às fontes de financiamento, em oposição à dificuldade de seu desenvolvimento em unidades isoladas. ${ }^{109}$ Além disso, os processos de concentração também envolvem motivos de ordem estratégica: (i) sinergias para redução de custos, (ii) aumento do poder de negociação das empresas perante clientes e fornecedores, (iii) ocupação de novos mercados, (iv) compartilhamento de atividades e recursos que permitem a maximização da criação de valor, e (v) terceirização de atividades industriais ou de distribuição de produtos. $^{110}$

Nesse contexto, as operações de incorporação, ao lado de outros institutos como aquisição de controle e fusão, inserem-se nesse processo concentracionista e ajudam a promovê-lo, tendo sido amplamente utilizadas como modo alternativo de aquisição de sociedades, à semelhança do que ocorre nos mercados de valores mobiliários mais desenvolvidos. ${ }^{111}$

incorporação de sociedades são inteiramente distintas, o que pode afetar a análise jurídica desses institutos nos métodos de avaliação, no tipo dos laudos e em outros detalhes importantes das operações (Incorporação de ações no direito brasileiro... cit., p. 133).

108 Cf. N. EIZIRIK, A Lei das S/A comentada... cit., p. 244.

109 N. EIZIRIK, Incorporação de ações: aspectos polêmicos... cit., p. 78. Vide também N. EIZIRIK, A Lei das S/A comentada... cit., p. 208.

110 N. EIZIRIK, A Lei das S/A comentada... cit., p. 209. F. C. PONTES DE MIRANDA menciona como causas da incorporação, de maneira genérica, o estabelecimento de uma unidade de direção, maior poder patrimonial e maior faculdade de produção (Tratado de direito privado, t. LI... cit., p. 65).

111 Cf. voto de Pedro Oliva Marcilio de Sousa, no Processo CVM n. RJ 2005/5203, rel. SEP, j. 24.08.2005. Convém notar que nos mercados mais desenvolvidos, como o americano, outros tipos de incorporação 
A larga utilização do instituto das incorporações de sociedades e incorporação de ações decorre não apenas dos benefícios típicos decorrentes da concentração empresarial acima expostos, mas justifica-se também, muitas vezes, por criar estrutura acionária compatível com as melhores práticas de governança corporativa das companhias envolvidas, por exemplo, mediante a eliminação de ações preferenciais em determinadas companhias incorporadas. ${ }^{112}$

Há, ainda, outros fatores que contribuem para a popularização das incorporações. Entre eles, citamos: (i) as economias trazidas em processos de aquisição de controle, já que não é necessário haver desembolsos de caixa ou de ativos para concluir a operação; (ii) o entendimento comum de que as operações de incorporação de ações mesmo quando geram troca de controle não requerem a realização de OPA por aquisição de controle prevista no art. 254-A da Lei de S.A. e não disparam as típicas cláusulas de poison pill dos estatutos; ${ }^{113}$ e (iii) possíveis benefícios fiscais na criação de ágios que podem vir a ser amortizados com proveitos fiscais caso as companhias sejam incorporadas no futuro. Para as incorporações de ação, a manutenção da personalidade jurídica da empresa cujas ações são incorporadas, evitando a transferência de passivos e contingências para a incorporadora, é ainda outro fator indutor de sua popularidade.

Além disso, o estudo da regulamentação dessas operações e dos mecanismos de proteção dos interesses dos acionistas torna-se ainda mais importante se levarmos em conta o cenário atual de desenvolvimento do mercado de capitais brasileiro. Se tais operações eram, até pouco tempo, razoavelmente desconhecidas pelos investidores, hoje sua realização cresce exponencialmente e envolvem empresas de grande expressão na

são utilizados que não a estrutura típica brasileira, como cash-for-stock merger e a tender offer seguida de short form merger. Short-form mergers são um procedimento sumário para a incorporação de sociedades nos casos em que a incorporadora é titular de mais de $90 \%$ das ações da incorporada. Tais operações são implementadas por decisão do órgão administrativo da incorporadora, sem necessidade de aprovação pelos administradores da incorporada. Aos acionistas da incorporada, é oferecido o direito de retirada como única medida protetiva. Nesses casos, a operação não passa pelo escrutínio do entire fairness (cf. S. M. BAINBRIDGE, Mergers and Acquisitions, New York: Foundation Press, 2003, p. 156157; e C. M. TOMAZELlA, Proteção de acionistas e credores nas operações de incorporação envolvendo sociedades anônimas, dissertação de mestrado apresentada à Faculdade de Direito da Universidade de São Paulo, 2011, p. 112).

112 Nesse sentido, vide também D. KALANSKY, Incorporação de ações... cit., p. 23).

113 As poison pills, tão comuns nos últimos tempos, em geral procuram incentivar e proteger a dispersão acionária das companhias ao elevar consideravelmente os custos para realização de vendas de montante significativo de ações para uma mesma pessoa. 
economia do país, afetando os interesses de investidores que exigem, cada dia mais, segurança e estabilidade dos mercados em que investem. Ultimamente, as operações envolvendo aquisições de companhias de capital aberto mais comentadas do mercado de capitais brasileiro têm sido efetuadas por meio do instituto da incorporação.

Especificamente, as operações de incorporação de ações têm sido bastante difundidas como fase preliminar à incorporação tradicional de sociedades, principalmente em setores regulados, devido às facilidades que as operações de incorporação entre controladora e subsidiária podem trazer.

Se a popularidade das operações de incorporação já seria justificativa suficiente para as estudarmos profundamente, soma-se a esse cenário a criatividade dos agentes econômicos que têm implementado mudanças no instituto clássico das operações de incorporação oferecendo novas questões para análise e reflexão. Um exemplo é o caso da incorporação com relações de troca diferenciadas para ações da mesma espécie e classe, que estudaremos neste trabalho.

As operações de incorporação estão, portanto, cada dia mais corriqueiras e é a questão da relação de troca das ações o ponto central de tais operações, dada sua importância para determinar os futuros direitos dos acionistas e por ser campo fecundo para a prática de abusos, fraudes e erros por parte dos controladores e administradores.

Feita uma análise genérica dos institutos da incorporação de sociedades e da incorporação de ações até aqui, passemos agora ao estudo da relação de substituição de ações nos capítulos seguintes. 


\section{2}

\section{RELAÇÃO DE SUBSTITUIÇÃO DE AÇÕES: CONCEITO, DETERMINAÇÃO E LIMITES}

A proposta deste capítulo é examinar o conceito da relação de substituição de ações e sua natureza jurídica, bem como onde ela se insere no contexto das operações de incorporação. A seguir, pretende-se demonstrar a importância dessa relação como ponto nevrálgico de qualquer operação de incorporação visto que representa o parâmetro definidor dos futuros direitos patrimoniais e políticos dos acionistas envolvidos em tais operações. Também serão exploradas algumas especificidades relativas exclusivamente à relação de troca em si, como, por exemplo, o tratamento legislativo conferido às frações de ações.

Na sequência, o presente capítulo analisará também o arcabouço legal dentro do qual se insere a determinação da relação de substituição, abordando os critérios, parâmetros e os requisitos que norteiam sua definição, bem como os mecanismos legais previstos pela legislação societária para composição de todos os interesses envolvidos, notadamente aqueles dos acionistas minoritários. A ideia neste capítulo é analisar a determinação da relação de substituição de ações no cenário mais simplificado possível, qual seja, sociedades anônimas fechadas, com acionistas controladores independentes, negociando uma única relação de troca para todas as ações emitidas. Casos especiais de relação de troca serão discutidos nos capítulos seguintes.

\subsection{Conceito de Relação de Substituição de Ações}

\subsubsection{Natureza Jurídica}

Como se viu no capítulo anterior, em que foram detalhados os procedimentos das operações de incorporação de sociedade e incorporações de ações, com a unificação de duas ou mais companhias ou com a incorporação das ações de uma companhia, as ações dos acionistas da sociedade incorporada ou da futura subsidiária integral são compulsoriamente substituídas pelas ações da sociedade incorporadora. Na incorporação de sociedades, a substituição das ações da sociedade incorporada pelas ações da 
incorporadora decorre de um dos efeitos jurídicos de tais operações, qual seja, a própria extinção da sociedade incorporada. ${ }^{114}$ Já na incorporação de ações, embora não haja extinção das ações incorporadas ou da sociedade que as emitiu, há também substituição compulsória de tais ações pelas ações da sociedade incorporadora por força de lei.

Antes da conclusão do negócio de incorporação, os acionistas das sociedades interessadas participam nos lucros e no acervo social apenas das sociedades de que são sócios, sabendo que cada ação confere direito a uma quota-parte do total dos lucros e do acervo daquela companhia. Com a unificação das companhias ou com a incorporação das ações de uma companhia, os antigos titulares de tais ações deixam de ter qualquer expectativa de direito que detinham na qualidade de acionistas das sociedades incorporadas ou cujas ações são incorporadas (inclusive direitos especiais conferidos a acionistas preferencialistas) ${ }^{115}$ e passam a ter novos direitos conferidos pelas ações da sociedade incorporadora, de modo que, em ambos os casos, o objeto direto de participação dos acionistas é compulsoriamente substituído pelos direitos de participação conferidos pelas ações da sociedade incorporadora. ${ }^{116}$

Como se vê, a substituição das ações com base na relação de troca negociada é decorrência lógica e natural das operações de incorporação, porém a natureza jurídica dessa relação de troca não é tão evidente, tampouco isenta de controvérsias.

De acordo com a doutrina majoritária, essa substituição de ações se dá por subrogação real legal, pois os acionistas da sociedade incorporada ou que têm suas ações incorporadas recebem, por força de lei e independentemente de sua vontade, os títulos da sociedade incorporadora em substituição aos títulos que anteriormente detinham, os quais

114 Ressalvamos aqui que (i) há hipóteses em que as operações de incorporação se realizam sem substituição de ações quando, por exemplo, não há nenhum aumento de capital na sociedade incorporadora, como discutiremos no item 2.1.5 abaixo; e (ii) o efeito de substituição das ações é característico no Brasil, mas não é obrigatório em todas as legislações, como será visto no item 2.1.3. Como se examinará neste trabalho, há casos de incorporação em que os acionistas da incorporada não recebem ações da incorporada, e sim pagamento em dinheiro ou bens como contraprestação às suas ações incorporadas.

115 Discutiremos a questão da substituição de ações de classes e espécies diferentes no item 3.3.

116 A. LAMY FILHO; J. L. BUlHÕES PEDREIRA (Coord.), Direito das companhias, v. 2, cit., p. 1761-1762. 
podem, inclusive, conferir direitos diferentes daqueles que eram antes detidos pelos acionistas. $^{117}$

Sub-rogação real é aquela que se dá pela substituição de uma coisa por outra, sem atenção às pessoas, titulares ativos e passivos dos direitos correspondentes, ao fim da qual as coisas substitutas ficam em lugar das coisas substituídas e, por consequência, tomam a natureza destas, suportando todos os encargos que lhes pesavam. Trata-se, em resumo, de uma coisa ocupar o lugar da outra em determinada relação jurídica que se conserva, preservando sua identidade. Caracteriza-se assim por ser uma modalidade particular de modificação objetiva de relação jurídica ou de sucessão. ${ }^{18-119}$

No entanto, a tese largamente defendida da sub-rogação real legal encontra algumas dificuldades de ser sustentada. Em primeiro lugar, nos casos de sub-rogação real, o bem substituto deve passar a integrar o mesmo regime jurídico do bem substituído. Nesse sentido, PONTES DE MIRANDA defende que na sub-rogação real ocorre a substituição jurídica de um bem por outro, de modo que o bem adveniente passe a integrar o patrimônio de onde saiu o bem substituído, passando a se submeter ao mesmo regime do bem substituído. ${ }^{120}$ Da mesma maneira, CAIO MÁRIO DA SILVA PEREIRA complementa dizendo que na sub-rogação há a sobrevivência do regime jurídico da coisa sub-rogada. ${ }^{121}$ Sob esse ângulo, portanto, seria possível argumentar que não existe verdadeiramente a figura da sub-rogação real nas operações de incorporação, pois a relação jurídica é alterada uma vez que, antes da conclusão da operação, a relação se dava entre acionistas da incorporada (ou da sociedade que tem suas ações incorporadas) e esta sociedade e, após a conclusão, a relação jurídica se dá com a sociedade incorporadora, podendo haver inclusive alteração nos direitos dos sócios. ${ }^{122}$ A sub-rogação real implica necessariamente uma substituição da

117 Cf., entre outros, N. EIZIRIK, A Lei das S/A comentada... cit., p. 225; A. LAMY FILHO; J. L. BULHÕES PEDREIRA (Coord.), Direito das companhias, v. 2, cit., p. 1766; e A. XAVIER, Incorporação de ações: natureza jurídica e regime tributário... cit., 2007, p. 133.

118 M. A. DOMIngues DE ANDRADE, Teoria geral da relação jurídica, Coimbra: Almedina, 2003, v. 2, p 21.

119 Cf. DE Plácido E SIlva, Vocabulário jurídico, apud A. LAMY FILHO; J. L. BUlhõeS PEDREIRA (Coord.), Direito das companhias, v. 2, cit., p. 1766. No mesmo sentido, M. CARVALHOSA; N. EIZIRIK, Estudos de direito empresarial... cit., p. 96.

120 F. C. PONTES DE MIRANDA, Tratado de direito privado, t. II, 3. ed., Rio de Janeiro: Borsoi, 1972, p. 151-153.

121 Instituições de direito civil, 19. ed., Rio de Janeiro: Forense, 2000, v.1, p. 274.

122 Vide nesse sentido D. KALANSKY, Incorporação de ações... cit., p. 51. 
participação social por outra, mas com a manutenção dos mesmos sujeitos da relação. Para que pudesse adequadamente explicar a relação de troca das operações de incorporação, as sociedades resultantes ao fim da operação e os acionistas deveriam, portanto, permanecer os mesmos, o que sabemos que não ocorre, pois a participação acionária adquirida se refere a uma nova sociedade e os títulos conferidos podem conferir novos direitos ou deixar de assegurar velhas prerrogativas. ${ }^{123}$

Além disso, há quem defenda que a sub-rogação de um bem por outro requer necessariamente a equivalência de valores de tais bens, de modo que não haja alteração no patrimônio dos sujeitos afetados. ${ }^{124}$ Como veremos mais adiante, entendemos que as operações de incorporação não pressupõem necessariamente a manutenção do valor das participações dos acionistas e, também por essa razão, a tese da sub-rogação parece não explicar perfeitamente o fenômeno da substituição das participações societárias.

Uma segunda corrente enxerga na relação de troca a figura da novação. A novação se caracterizaria mediante a extinção da relação anterior para formação de uma nova relação do acionista com a sociedade incorporadora, decorrente da extinção da participação social detida pelo sócio e aquisição, a título originário, de uma nova participação na sociedade incorporadora. ${ }^{125}$ Diz-se que a aquisição das novas ações se daria a título originário porque as operações de incorporação não implicam nenhum ato de troca entre os sócios das sociedades ou mesmo entre os sócios e a sociedade incorporadora, de maneira que não se poderia falar em aquisição derivada de tais novas ações. ${ }^{126}$ A crítica

123 Vide D. C. GONÇALVES, Fusão, cisão e transformação de sociedades comerciais: a posição jurídica dos sócios e a delimitação do statuo viae, Coimbra: Almedina, 2008, p. 152. O autor também exclui a possibilidade de que a relação de troca seja equiparada a uma sub-rogação pessoal na qual haveria troca do sujeito da relação jurídica, no caso, a sociedade incorporada ou que tem suas ações incorporadas, por uma nova sociedade, enquanto o objeto da relação - a participação social, vista sob a óptica de uma situação jurídica de sócio - permaneceria a mesma. Com razão, o autor demonstra que também não é válida essa aproximação, dado que as operações de incorporação podem operar significativas alterações na "situação jurídica dos sócios" por meio de eliminação de direitos de determinadas ações ou até mesmo recebimento em dinheiro de montante de suas ações, como permitido em algumas legislações (idem, p. 152-155).

124 M. CARVAlHOSA; N. EIZIRIK, Estudos de direito empresarial... cit., p. 96.

125 Vide D. C. GONÇALVES, Fusão, cisão e transformação... cit., p. 157.

126 Idem, ibidem, p. 158. Como se sabe, o titular das ações a serem objeto de incorporação não pratica nenhum ato e nada transmite, limitando-se passivamente a receber da sociedade incorporadora ações substitutivas das originariamente detidas (cf. A. XAVIER, Incorporação de ações: natureza jurídica e regime tributário... cit., p. 141; e N. EIZIRIK, Incorporação de ações: aspectos polêmicos... cit., p. 80). No mesmo sentido, R. VENTURA diz que, na verdade, não há nenhuma troca nas incorporações porque “as novas participações são adquiridas a título originário e não derivado" (Fusão, cisão, transformação 
à teoria da novação está, justamente, no que se refere à aquisição originária das participações sociais postulada por essa tese, a qual não está de acordo com a real vontade dos sócios e tampouco com o perfil econômico e jurídico da fusão. Nos processos de incorporação, não se busca a aquisição de uma nova participação social como ocorre na constituição de uma sociedade, mas, pelo contrário, a aquisição das ações da sociedade incorporadora se dá em decorrência de um direito anterior, obedecendo a um critério de tutela dos sócios da sociedade incorporada ou que têm suas ações incorporadas, de maneira que a tese de uma aquisição originária parece não se sustentar nesse contexto. Além disso, carece a demonstração clara de qualquer animus novandi emitido pelo sócio que terá suas ações substituídas pelas ações da incorporadora, já que em uma operação de incorporação não há manifestação expressa de cada sócio para receber as novas ações podendo, inclusive, haver sócios que se manifestam contrariamente à realização da operação. ${ }^{127}$

D. C. GONÇALVES, por sua vez, integra uma terceira corrente que defende que a relação de troca pressupõe sempre uma manutenção do status socii dos acionistas da sociedade incorporada (ou daqueles que têm suas ações incorporadas). Isso porque, mesmo que as situações jurídicas dos sócios sofram algumas modificações, há sempre uma identidade no status socii dos acionistas que decorre da dependência existente entre as antigas e as novas participações recebidas pelos sócios e do caráter de continuidade das suas posições jurídicas que caracteriza as operações de incorporação. ${ }^{128}$

de sociedades: comentário ao Código das Sociedades Comerciais, Coimbra: Almedina, 3. reimp. da 1. ed. de 1990, 2006, p. 246).

127 Cf. D. C. GONÇALVES, Fusão, cisão e transformação... cit., p. 159-160.

128 Idem, ibidem, p. 136 e 162-166. Na mesma linha, C. SANTAGATA defende que "certo è che il titolo della partecipazione non si costitusce ex novo in dipendenza della stipulazione in favore del socio nel negozio di fusione: il fondamento della partecipazione è invece già precostituito. Infatti, è incontesttabile il duplice dato che titolo esclusivo per la partecipazione ad una società è un conferimento ad essa effetuato, laddove, in sede di fusione, alcun ulteriore apporto effetuano i soci della incoporante o risultante della fusione, A tale stregua, l'unica giustificazione plausibile consiste nel ritenere che la partecipazione a questa società si fondi sullo stesso titolo e, precisamente, in virtù dell'adesione già prestata al contratto sociale presso la società alla quale essi hanno originariamente effetuato il proprio apporto. [...] I singoli rapporti di partecipazione permangono ancorati allo stesso titolo, costituito dall'adesione già prestata al contratto sociale presso la società originaria che ha deciso la fusione; e persistono a trarre la loro giustitficazione causale nell'originario conferimento effetuato alle rispettive società." (La fattispecie della fusione, in: GRIFFI, A. P., Fusioni e Scissioni di Società, Milano: Giuffrè, 1995, p. 4-5). O caráter de continuidade das participações societárias presente nas operações de incorporação também foi percebido por A. PÉREZ TROYA que o coloca como um pressuposto básico dessas operações (La determinación del tipo de canje... cit., p. 109). 
Para o autor, como a participação social se mantém a mesma (ainda que sofra algumas modificações com a conclusão da operação), não há que se falar verdadeiramente em uma troca de participações sociais, nem na extinção de uma participação e a aquisição de outra. Existe, na realidade, a substituição da participação com a manutenção do mesmo status socii, modificado, no entanto, por conta de uma reestruturação socioempresarial que é a operação de incorporação.

Assim, nem mesmo a extinção da sociedade incorporada poderia desqualificar a manutenção do status socii dos acionistas porque, na verdade, do ponto de vista dos sócios, a operação de incorporação ou fusão é um processo positivo ligado ao alargamento da empresa e não um processo encarado sob a óptica extintiva da sociedade. ${ }^{129} \mathrm{O}$ sócio, de fato, não vota a extinção da sociedade incorporada e muito menos a extinção da sua participação; pelo contrário, o que os sócios deliberam é a realização da operação de incorporação, de modo que, para os sócios, a fusão não é um processo negativo (de extinção da sociedade e de sua participação), e sim um processo positivo de alargamento da empresa. ${ }^{130}$ Além disso, como processo modificativo celebrado entre sociedades, podese dizer que a repercussão dos efeitos das incorporações na esfera dos sócios é, de certa maneira, indesejada ou, pelo menos, adjetiva em relação ao efeito da compenetração dos patrimônios sociais. Tendo que ocorrer, mas não sendo desejada, a troca de participações deve ser entendida não como o desaparecimento de uma posição jurídica para alcançar outra que a substitui, e sim como a manutenção do mesmo status socii em outra sociedade que é recebida com o intuito de recriar a posição jurídica dos sócios na sociedade incorporadora. ${ }^{131}$ A doutrina de E. SIMONETTO, nesse ponto, também é bastante elucidativa

129 Cf. D. C. GONÇALVES, Fusão, cisão e transformação... cit., p. 165-166. Dessa maneira, a extinção da incorporada deveria ser vista, na verdade, como a extinção de uma sociedade sem sócios e sem patrimônio, depois de já realizada a transferência dos sócios e do patrimônio para a sociedade incorporadora (idem, p. 162-164). No caso das incorporações de ações, a ausência de extinção da sociedade que tem suas ações incorporadas elimina essa questão e, por essa razão, seria ainda mais fácil defender a tese acima. Nesse sentido, D. KALANSKY defende que "a continuidade [...] do vínculo social poderia ser defendida na medida em que a incorporada não se extingue, recebendo os acionistas ações de outra sociedade por uma decisão assemblear prevista em lei” (Incorporação de ações... cit., p. 51).

130 Nesse mesmo sentido, vide A. MENEZES CORDEIRO ao defender que "seria irreal ver, na fusão, um animus destruidor, tendente a fazer desaparecer seja o que for" (Manual de direito das sociedades... cit., p. 964).

131 Cf. D. C. GONÇALVES, Fusão, cisão e transformação... cit., p. 136-137. A doutrina francesa tem designado esta realidade como "parité d'echange des droits sociaux", expressão bastante sugestiva e que demonstra a busca em assegurar, na sociedade incorporadora, uma recriação da posição social tão semelhante quanto possível em comparação com aquela anteriormente detida (M. COZIAN; A. VIANDIER; F. DEBOISSY, Droit des Sociétés, 19. ed., Paris: Litec, 2006, p. 565). 
ao dizer que a fusão não corresponde a uma extinção da sociedade, e sim à unificação de participações sociais em torno de um núcleo único. ${ }^{132}$

Essa última teoria parece-nos ser a mais adequada, pois analisa a relação de troca do ponto de vista do direito societário, sem tentar encaixá-la sob outras figuras típicas do direito civil que não correspondem precisamente ao que se vê na realidade de tais operações. Além disso, essa posição parece estar correta quando analisada à luz da vontade real dos sócios e da realidade socioeconômica das operações de incorporação. De fato, nem os sócios nem as sociedades envolvidas em uma operação de incorporação têm por meta transformar tais operações em um negócio jurídico de troca de participações sociais, mas as realizam com o intuito precípuo de promover a concentração empresarial em um único ente societário (inclusive com unificação do substrato patrimonial no caso das incorporações de sociedades). ${ }^{133}$ Essa ideia de continuidade das participações societárias evidencia, portanto, que a atribuição das ações aos sócios não deriva de uma contraprestação pelo patrimônio transmitido, mas é uma consequência da própria operação, o que evita também termos de recorrer a soluções artificiais para explicar por que são os sócios que recebem diretamente as ações enquanto é a sociedade incorporada ou que tem suas ações incorporadas que transmite o patrimônio ou as ações de seus acionistas. ${ }^{134}$

Ainda sobre a natureza jurídica da relação de troca, é necessário distingui-la da figura de um "preço" pago nas operações de incorporação como uma contraprestação recebida pelos acionistas da sociedade incorporada ou que têm suas ações incorporadas. Embora essa aproximação seja corriqueira, ela não é correta. Assim como a natureza jurídica da incorporação não equivale a um contrato de compra e venda ou cessão de bens, a relação de troca não é análoga ao preço existente em uma cessão ou alienação de ações.

Há, certamente, diferenças fundamentais entre o preço pago ou recebido em aquisições tradicionais e as ações que se substituem nas operações de incorporação. Tais diferenças repousam, primeiramente, na figura daquele que negocia a operação. Nas operações de incorporação, a troca das ações da incorporada pela incorporadora foi

\footnotetext{
132 Cf. Delle societá - transformazione e fusione dele società, società costituite all'estero od operante all'estero, 2. ed., Roma: Zanichelli, 1976, p. 221-22.

133 Vide D. C. GONÇALVES, Fusão, cisão e transformação... cit., p. 137-138.

134 Cf. A. PÉREZ TROYA, La determinación del tipo de canje... cit., p. 109.
} 
negociada não pelo titular das ações que serão substituídas, mas pelos órgãos da administração (ou por um dos sócios) que tenham firmado o protocolo da operação. Como se viu acima, a subscrição e a integralização do capital da sociedade incorporadora não são realizadas pelos futuros acionistas, e sim pelos administradores da sociedade incorporanda em decorrência de um negócio que se deu entre sociedades, de modo que a substituição das ações não decorre de atos individuais de alienação praticados por cada acionista, e sim como consequência prevista em lei para o negócio aprovado e em decorrência do caráter de continuidade das participações sociais. ${ }^{135}$.

Daí se tira também a segunda diferença fundamental entre a substituição das ações e a figura do preço, pois se sabe que as operações de incorporação são de natureza compulsória para todos os acionistas se aprovadas pelas respectivas assembleias gerais. ${ }^{136}$ Diferentemente do que ocorre nas incorporações, processos de compra e venda de ações são negociados, em geral, pelos próprios titulares dessas ações e tais titulares não são obrigados a realizar a operação se não estiverem satisfeitos com suas condições. Nas operações de incorporação, no entanto, a troca das ações da incorporada pela incorporadora é obrigatória.

A substituição das ações não é, portanto, efeito de um negócio jurídico de alienação entre os acionistas titulares das ações extintas e acionistas da sociedade incorporadora, como os negócios de cessão ou permuta.

A aproximação com a figura de um preço procede apenas na medida em que, como veremos, existe certa liberdade conferida pela lei para determinação da relação de troca entre as companhias que podem chegar a relações de troca melhores ou piores para seus acionistas. A semelhança, por assim dizer, encerra-se aí. ${ }^{137}$

135 Em sentido semelhante, C. SANTAGATA diz que "[non] recorre, dunque, creazione di nuovi rapporti di partecipazione né, tanto meno, il loro transferimento. La confluenza degli originari rapporti nell’ente incorporante o risultante dalla fusione si realizza già programmaticamente nell'ambito di ciascuna società che vi partecipa, restando così superata l'esigenza di un consenso dei singoli soci alla (eventuale) redistribuzione" (La fattispecie della fusione... cit., p. 8).

136 Como contraponto, sobre a autonomia da vontade das partes no negócio de compra e venda e sobre a definição do preço, vide F. C. PONTES DE MIRANDA, Tratado de direito privado, t. XXXIX, 3. ed., Rio de Janeiro: Borsoi, 1972, p. 18 e ss.

137 D. A. VIO, P. L. CASAGRANDE e R. P. FREOA chegam a afirmar que em uma operação regular de incorporação ou incorporação de ações as relações de troca são negociadas livremente pelas duas 
A necessidade de adequação do valor da relação de substituição de maneira que preserve os direitos dos sócios das sociedades envolvidas e faça com que a operação em si corresponda ao interesse social, sob pena de ter atacada sua validade, faz com que a relação de troca não possa ser aproximada de um direito patrimonial disponível tal como ocorre nos contratos de permuta. ${ }^{138}$ A contraprestação considerada para um contrato de permuta pode compreender elementos subjetivos, já a relação de troca comporta outros tipos de limites e caracteriza-se por seu uma discussão muito mais técnica e, a princípio, menos carregada de subjetividade por cada parte. ${ }^{139}$

Não apenas por essa razão, mas também por conta do processo peculiar de tais operações, que envolve verdadeira desfiguração dos valores mobiliários atingidos e com caráter compulsório da operação, e a característica de que a relação de troca é negociada pela administração como verdadeira gestão no interesse de outrem, afasta-se a relação de substituição do conceito de preço puro. ${ }^{140}$

maiorias societárias como o preço de qualquer contrato (Conflito de interesse na incorporação e incorporação de ações - o Parecer de Orientação n. 34/06 e Parecer de Orientação n. 35/08 da CVM, in: E. S. MUNHOZ; M. R. PENTEADO (Coord.), Mercado de capitais brasileiro: doutrina, cases \& material, São Paulo: Quartier Latin, 2012, p. 159). Em nota de rodapé, os autores citam P. C. ARAGÃO e M. M. MAVIGNIER DE LIMA quando dizem que se aplicam a tais operações a liberdade de contratar, o que permite às administrações e aos sócios das sociedades envolvidas convencionarem a relação de substituição das ações e as regras que embasarão o critério de valoração do patrimônio líquido das mesmas sociedades a serem incorporadas (Incorporação de controlada... cit, p. 346). Concordamos com E. F. DE PONTES ao dizer que a diferença de abordagem é sutil, mas existe: a liberdade de estabelecer uma relação de substituição diz mais a respeito da escolha e aceitação dos métodos de avaliação e critérios que desaguarão em um eixo de equivalência da operação do que propriamente a negociação de um valor per se como ocorre nos contratos de permuta (Incorporação de ações no direito brasileiro... cit., p. 114). O conceito de eixo de equivalência desenvolvido pelo autor será explorado mais adiante quando abordarmos os limites para a determinação da relação de substituição de ações.

Veremos no item 2.2.4 abaixo que, por essa mesma razão, nem mesmo a convalidação da assembleia geral da relação de troca proposta pode superar esses vícios. É de notar que até mesmo contratos de permuta, como é o caso da cessão de ações, assumem contornos distintos sob a óptica societária quando falamos em uma cessão de ações que assegurem o controle acionário. Nesses casos, o negócio deixa de ser visto sob as lentes dos negócios puramente privados para ser visto como um contrato que tem reflexos na sociedade e na empresa (cf. E. VALLADÃO A. e N. FRANÇA, Dever de lealdade do acionista controlador por ocasião da alienação de controle - dever de maximização do valor das ações dos acionistas não controladores - interpretação de estatuto de companhia aberta - possibilidade de cumulação de OPAS, Revista de Direito Mercantil Industrial, Econômico e Financeiro, n. 158, São Paulo: Malheiros, 2011, p. 257; e CALIXTO SALOMÃo FILHO, O novo direito societário, 4. ed., São Paulo: Malheiros, 2011, p. 151). Se isso ocorre com o contrato de cessão de controle, muito mais razão existe para não considerar como negócio puramente privado as operações de incorporação.

139 Vide nesse sentido D. KALANSKY, ao afirmar que há uma liberdade convencional dos parâmetros para a determinação da relação de troca, o que não significa que exista uma liberdade ilimitada para negociar diretamente a relação de troca em si (Incorporação de ações... cit., p. 84).

140 Cf. E. F. DE PONTES, Incorporação de ações no direito brasileiro... cit., p. 43. 
A verdade é que as companhias não negociam a relação de troca como se fosse o preço de um contrato de permuta, mas, sim, métodos de avaliação de seus respectivos patrimônios bem como avaliações dos possíveis benefícios previstos com a operação de forma a determinar um intervalo ou um eixo de equivalência da operação para os acionistas de ambas as companhias dentro do qual a relação de troca das ações será estabelecida. ${ }^{141}$ Portanto, a relação de troca é, ou deveria ser, determinada de maneira indireta, fruto de um debate muito mais complexo do que a negociação de um preço em que os alienantes nem mesmo participarão do conglomerado que irá resultar da operação. Nas operações de permuta, as partes avaliam o bem e a contraprestação solicitada pela troca de titularidade desse mesmo bem de forma isolada e o elemento da vontade é sempre fundamental. Nas operações de incorporação, há nitidamente um elemento compulsório e a avaliação de cada bem não se faz de modo isolado, mas em conjunto com os demais bens e partes da operação, de maneira que determine qual o bem final que caberá a cada parte. Ao alinhar premissas e expectativas de possíveis resultados para a operação, o que as partes fazem é negociar métodos de avaliação e ajustar prognósticos do futuro das operações combinadas, evitando uma maximização desarrozoada da contraparte na relação de troca que determinará a realização da operação. ${ }^{142}$

Além disso, no bojo das operações de incorporação muitos outros fatores são levados em conta para a determinação da relação de substituição: ao lado dos valores meramente financeiros, os direitos políticos das ações também são discutidos e negociados, podendo migrar de uma companhia para outra, de modo que a questão muitas vezes não se resolve apenas na relação de troca de ações. Trata-se, portanto, de duas ou mais companhias e de dois ou mais elementos (os patrimônios ou as ações dessas companhias, referenciados em uma autoavaliação) com todas as características que compõem seu valor financeiro e político e na qual se buscará uma equivalência de termos com o mínimo de alteração ao estado de sócios possível e que, ao fim, afetará todos os lados envolvidos. ${ }^{143}$

Alguns autores apontam ainda uma distinção entre a relação de substituição de ações nas incorporações de sociedades e nas incorporações de ações em função das suas peculiaridades. Nas operações de incorporação de ações, o objeto de avaliação são

\footnotetext{
141 Aprofundaremos a forma determinação da relação de troca no item 2.3.2.1.2 abaixo.

142 Cf. E. F. DE PONTES, Incorporação de ações no direito brasileiro... cit., p. 114.

143 Idem, ibidem.
} 
precisamente as ações que serão incorporadas, cujo valor será estabelecido com base na avaliação do patrimônio da companhia emissora de tais ações. Já nas incorporações de sociedades, é o próprio patrimônio da companhia incorporada que será avaliado e as ações a serem emitidas pela incorporadora levarão em consideração o valor do patrimônio da incorporada e não o valor de suas ações, as quais, como se sabe, serão extintas. Em vista disso, alguns autores como E. F. DE PONTES entendem que só existe real substituição e troca de ações nas operações de incorporação de ações, em relação às quais se pode falar em relação de troca pura, em oposição às operações de incorporação de sociedades, que implicariam uma relação de troca imprópria. ${ }^{144}$ Não obstante, entendemos que não há efetivamente troca de participações em nenhum dos casos conforme expusemos acima.

Por fim, mais uma especificidade no caso das incorporações de ações merece ser comentada, já que vez ou outra se sugere a existência de uma desapropriação nas incorporações de ações, o que não se passa nas incorporações de sociedades. Isso se deve ao fato de que, para que se configure a desapropriação, é necessária a continuidade da existência do título original (as ações incorporadas, no caso) como ocorre na incorporação de ações e não na incorporação de sociedades. Em outras palavras, o título deve deixar de pertencer a uma pessoa para pertencer a outra em decorrência de uma operação compulsória. Todavia, o paralelo com o conceito de desapropriação pode ser questionado na incorporação de ações, pois o título continua existindo, mas sem que seja garantido o valor real dos títulos incorporados. ${ }^{145}$

\subsubsection{Importância da Relação de Substituição de Ações}

Do ponto de vista da proteção dos interesses e direitos dos acionistas das companhias que são partes de uma operação de incorporação, sejam elas incorporadoras ou incorporadas, a estipulação do negócio mais importante é, sem dúvida, a determinação da

\footnotetext{
144 E. F. DE PONTES, Incorporação de ações no direito brasileiro... cit., p. 125.

145 Idem, ibidem, p. 19-20. Segundo o autor, a obrigatoriedade do pagamento em dinheiro (cf. também J. CRETElla JUNIOR, Tratado de desapropriação, Rio de Janeiro: Forense, 1980, v. 1, p. 25-26) ou, em alguns casos em que se admite o pagamento em títulos da dívida pública, a obrigatoriedade de se preservar o valor real do bem desapropriado distancia o instituto da desapropriação da incorporação de ações. Seria naturalmente ilegal formular protocolo que assegurasse o valor real das ações incorporadas em relação às ações da incorporadora, indo contra a própria natureza de renda variável das ações. No caso das desapropriações com pagamento em títulos de dívida com cláusula de preservação do valor real, o título a ser entregue tem natureza de quase moeda e não de renda variável como as ações.
} 
relação de substituição de ações. ${ }^{146}$ Isso porque, a operação visando a reduzir os dois patrimônios envolvidos a um denominador comum para fixar a fração da situação patrimonial unificada que caberá a cada acionista reveste-se de complexidade profunda e poderá resultar em vantagem ou prejuízo para os acionistas tanto da incorporadora como da incorporada. ${ }^{147}$ Aliás, curioso o descaso com os acionistas da incorporadora geralmente conferido pela doutrina e até mesmo pela legislação quando prevê o direito de retirada apenas para acionistas da incorporada nas incorporações de sociedades, pois tais acionistas podem ser tão ou mais abalados pelas operações de incorporação quanto os acionistas da sociedade incorporada ou que têm suas ações incorporadas. ${ }^{148}$

Por serem justamente as características e a quantidade de ações distribuídas a cada acionista que definirão a extensão do exercício de direitos patrimoniais e políticos pelo acionista dentro de uma companhia, os dispositivos da legislação societária regulamentando a fixação da relação de troca de ações são de fundamental importância para a defesa dos interesses dos acionistas das sociedades envolvidas na incorporação. ${ }^{149} \mathrm{O}$ problema diz respeito, então, não apenas ao aspecto econômico - essencial, porque significa participação no acervo e nos lucros da companhia - mas, também, aos demais atributos da ação, como o poder político que tem no funcionamento da sociedade, no voto, nos direitos de preferência em caso de aumento de capital e até mesmo de perda de direitos ou vantagens atribuídas a determinadas ações.

146 Cf. A. LAMY Filho; J. L. Bulhões PedreiRA (Coord.), Direito das companhias, v. 2, cit., p. 1762 ; A. PÉREZ TROYA, La determinación... cit., p. 21; e D. C. GONÇALVES, Fusão, cisão e transformação... cit., p. 151; e G. TANTINI, Transformazione e Fusione delle Società, in: F. GALGANO, Tratatto di Diritto Commerciale e di Diritto Pubblico Dell'Economia, Padova: Cedam, 1985, v. 8, p. 313-314.

147 Cf. A. LAMY FILHO; J. L. BULhõES PEDREIRA, A Lei das S.A. (pressupostos, elaboração, aplicação)... cit., p. 679.

148 O problema também já foi sentido na doutrina estrangeira, conforme L. A. HAMERMESH salienta ao dizer que "there is sure something anomalous in the way corporate law deals with the duties of acquiring firm directors relative to those of the target firm. Fiduciary duties presumably respond to and address, at least in part, concerns over vulnerability to agency costs. Therefore, one might expect those duties to be most aggressively defined an enforced where concerns over such vulnerability are the greatest. It is not clear, however, that in stock-for-stock mergers, or even in mergers generally, target firm shareholders are more vulnerable to director misbehavior than acquiring firm shareholders" (Premiums in Stock-forStock Mergers and Some Consequences in the Law of Director Fiduciary Duties, University of Pennsylvania Law Review, v. 152, n. 2 (Dec., 2003), p. 907).

149 Nesse sentido, F. OLEO BANET afirma que "tanto las negociaciones como el procedimento jurídico que vertebran las operaciones de fusión y escissión de sociedades tienen por objeto principal la determinación de la relación de canje de los títulos de participación de las sociedades intervenientes en las mismas" (apud A. PÉREZ TROYA, La determinación... cit., p. 21). 
A própria exposição de motivos da Lei das S.A. já dizia que as operações de incorporação devem ser reguladas minuciosamente já que implicam excetuar o direito de preferência dos acionistas da sociedade incorporadora, diminuindo seus direitos de participação por conta do ingresso dos novos acionistas na incorporadora. Com a unificação, o objeto dos direitos de participação na incorporadora que compõem as posições de cada sócio passa a representar uma quota-parte menor do que a dos direitos preexistentes à operação, pois o número de sócios é maior. Assim, cada acionista passa a ter na sociedade incorporadora porcentagem menor do que detinha antes da conclusão da operação, o que, sem dúvida, afeta drasticamente a extensão dos seus direitos.

Do ponto de vista dos acionistas da sociedade incorporada ou daqueles que têm suas ações incorporadas, as questões ligadas à determinação da relação de substituição das ações são também vitais para a proteção de seus interesses já que a extensão de seus direitos na sociedade incorporadora será pautada pelo número de ações que receberem quando forem concluídas as operações. Do ponto de vista da sociedade incorporadora, seus direitos também serão abalados quanto mais sejam diluídos para recepção de tais acionistas.

Em segundo lugar, a maior ou menor flexibilidade na fixação da relação de substituição das ações conferida pelas legislações pode dar margem a comportamentos oportunistas e discricionários por parte dos acionistas controladores que desejem se beneficiar na redistribuição do patrimônio social a seu favor. Por isso, constata-se a crescente preocupação em se determinar de maneira apropriada a questão da relação de troca já que as operações de incorporação têm se constituído como campo fecundo para a proliferação de erros, fraudes e agravos contra minoritários, ainda mais se levarmos em conta que as incorporações são um ato drástico, definitivo e compulsório para os acionistas.

\subsubsection{Contraprestações Admitidas e Frações de Ações}

Vimos até esse momento que as operações de incorporação pressupõem o recebimento pelos acionistas da sociedade incorporada (ou por aqueles que têm suas ações incorporadas) de ações da sociedade incorporadora de acordo com a relação de substituição negociada entre as sociedades envolvidas. 
No entanto, o pagamento exclusivo em ações nem sempre é obrigatório em todas as legislações. Na Europa, a ponderação sobre a admissibilidade de outras contrapartidas para os sócios que não ações da incorporadora viveu sempre entre a recusa da dogmática, em vista da natureza das operações de fusão e incorporação, e a exigência prática da sua admissão. Se, por um lado, a possibilidade de atribuição de outras contrapartidas desvirtuaria a figura da fusão como um processo de concentração societária entre sociedades e não mera concentração de ativos por uma sociedade exclusiva, por outro, a dificuldade prática em operacionalizar a troca de participações exigia que os sócios pudessem receber outras contrapartidas para assegurar a proporcionalidade da operação. $^{150}$

Na União Europeia, com base na evolução da legislação e da doutrina alemã, a Diretiva 2011/35 inovou e previu que, juntamente com as ações da sociedade incorporadora, pudesse eventualmente ser atribuída aos acionistas quantia em dinheiro não superior a $10 \%$ do valor nominal das ações da incorporadora sendo conferidas em virtude da operação ou, na falta de valor nominal, do seu valor contabilístico. ${ }^{151-152}$

Como dissemos acima, essa permissão tem o intuito de facilitar a relação de troca quando não é possível a atribuição de números inteiros de ações a determinados acionistas. ${ }^{153}$ Por essa mesma razão, a redação proposta pela Diretiva 2011/35 e incorporada pelas demais legislações nacionais na Europa recebe críticas por não ter regulado de maneira mais específica o caráter "eventual” da atribuição em dinheiro,

150 Cf. D. C. GONÇAlves, Fusão, cisão e transformação... cit., p. 167. Na doutrina alemã, R. FISCHER, mesmo na ausência de lei e diante de entendimentos contrários à possibilidade de atribuição de outras contraprestações que não ações, já dizia que “[...] la sociedade subsistente puede muy bien conceder a los socios de la sociedaded disuelta, además de sus acciones, otros valores, en la media que sea imposible concederles acciones dentro de las normas de la tasación proporcional que rigen en las sociedades anónimas" (Las sociedades anónimas: su régimen jurídico; tradução do alemão por W. Roces, Madrid: Reus, 1934, p. 518-519).

151 Vide art. 3. ${ }^{\circ}-1$, art. $4 .^{\circ}-1$, art. $5 .^{\circ}-2$ (b) da Diretiva 2011/35.

152 A limitação dos $10 \%$ tem inspiração no antigo $\$ 344(2)$ da Aktiengesetz que consagrou o "zehnten Teil des Gesamtnennbetrags der gewährten Aktien", que tinha o intuito de facilitar a relação de troca e, ao mesmo tempo, garantir que a maior parte das contrapartidas fosse baseada na atribuição de participações societárias (cf. R. FISCHER, Las sociedades anónimas... cit., p. 519-520; e D. C. GONÇALVES, Fusão, cisão e transformação... cit., p. 168).

153 Cf. European Communities Commission, "provision had to be made for the fact that because of the share exchange terms it would not be possible to avoid all cash adjustments. These are therefore permissible without preventing the operation from constituting a merger, provided they do not exceed 10 per cent of the nominal value of the shares allotted, or in the absence of a nominal value, their book value" (Report on the Draft Convention on the International Merger of Sociétés Anonymes, 29.06.1973, disponível em: <http://aei.pitt.edu/5613/01/002317_1.pdf>, acesso em: 5 abr. 2013, p. 43). 
gerando debates a respeito da possibilidade de que a contrapartida em dinheiro seja feita por livre escolha da administração mesmo quando não seja estritamente necessária para garantir o acerto proporcional dos sócios de acordo com a relação de substituição negociada, ${ }^{154}$ exceção feita apenas à legislação espanhola que previu no art. 25 da Ley 3/2009 que o pagamento em dinheiro poderá ser realizado quando for conveniente para ajustar a relação de troca, o que leva a crer que, em demais situações em que a relação de troca tiver sido fixada em números inteiros, a atribuição de quantia em dinheiro seria inválida, bem como seria também inválida apenas a atribuição em dinheiro a determinado acionista sem que receba alguma ação da sociedade incorporadora. ${ }^{155}$

Toda essa discussão está também ligada a uma questão fundamental e bastante controvertida de saber se o direito que o acionista tem em relação à sociedade pode ser extinto ou substituído quanto ao objeto, sem o consentimento do interessado, com o intuito de realizar uma operação de incorporação. Nesse contexto, existem aqueles que defendem que o interesse social prevalece sobre o interesse dos sócios em realizar a operação e que, portanto, a atribuição em dinheiro seria lícita mesmo sem o consentimento daqueles que são, em teoria, prejudicados pelo recebimento da quantia em dinheiro, ${ }^{156}$ e outros autores que entendem que, mesmo nos casos das operações de incorporação em fusão, o interesse do sócio em manter sua participação social não pode ser elidido sem o seu consentimento, pois a maioria não teria o direito de afastar da sociedade quem nela queira continuar ou tampouco diminuir a participação de um sócio. ${ }^{157}$ A atribuição de participação em dinheiro feriria, inclusive, a natureza jurídica da incorporação e da relação de troca das ações que deveria recriar na sociedade resultante o status socii existente entre os acionistas da sociedade incorporada. ${ }^{158}$

154 Vide nesse sentido, D. C. GONÇALVES, Fusão, cisão e transformação... cit., p. 171-175, para quem a contrapartida em dinheiro deve ser necessariamente residual. No mesmo sentido, C. SANTAGATA, $L a$ Fusione Tra Società, Napoli: Morano, 1964, p. 258.

155 Cf. A. PÉREZ TROYA, La determinación del tipo de canje... cit., p. 106.

156 Cf. G. BAUdeU; G. Bellargent, apud R. VENTURA, Fusão, cisão, transformação... cit., p. 87. Em sentido semelhante, C. SANTAGATA entende que não é essencial a compenetração dos grupos sociais para a figura da incorporação (La Fusione Tra Società... cit., p. 77). Da mesma maneira, W. BUlgarelli, Fusões, incorporações... cit., p. 102 e M. C. DE CASTRO NEVES, Incorporação de sociedade com patrimônio líquido negativo, Revista Forense, v. 345, Rio de Janeiro: Forense, 1999, p. 111.

157 Cf. R. VENTURA, Fusão, cisão, transformação... cit., p. 87.

158 Vide D. C. GONÇALVES, Fusão, cisão e transformação... cit., p. 177-178. Para o autor, a atribuição em dinheiro de um valor superior aos $10 \%$ não seria possível nem mesmo no caso de consentimento dos 
Optando por uma terceira linha, D. C. GONÇALVES defende que seria lícita a atribuição de quantia em dinheiro nos casos em que ela se fizer necessária para atender ao interesse social na realização da operação, mas, por outro lado, restaria aos sócios afetados o direito de se opor à fusão. Como consequência dessa oposição, tais sócios receberiam ações parciais, sem nenhum direito perante a companhia, as quais esperariam a reunião de outras "partes de direito" até que gozassem da unidade mínima para que pudessem ser plenamente exercidas. ${ }^{159}$

Não obstante toda discussão em solo europeu sobre a admissibilidade do pagamento em dinheiro, em Delaware, a liberdade para estruturação de uma operação é radicalmente maior no que tange às possíveis contrapartidas a serem atribuídas aos acionistas. De acordo com o $§ 251(b)(5)$ da Delaware General Corporation Law, não se exige que os acionistas da incorporada recebam, necessariamente, ações da sociedade incorporadora como contraprestação às suas ações, sendo possível atribuir aos acionistas da incorporada ações da incorporadora, ações emitidas por outras sociedades, títulos de dívida, dinheiro em espécie e qualquer outro tipo de bem. ${ }^{160}$

No Brasil, a Lei das S.A. não previu a possibilidade de que os acionistas recebam qualquer outra contrapartida que não ações da sociedade incorporadora com a conclusão das operações de incorporação. ${ }^{161}$ Por essa razão, assim como acontecia na legislação europeia, essa restrição gera problemas práticos quando a relação de substituição de ações não prevê a atribuição de ações aos acionistas em números inteiros.

sócios, pois não está em causa apenas um direito do sócio à intangibilidade de sua participação, mas existe, por outro lado, um dever de sociabilidade que recai sobre todos sócios, cujas origens remontam ao pacta sunt servanda e à subordinação ao interesse social. Esse dever de sociabilidade importa que a nenhum sócio seja permitido afastar-se da sociedade sem razão justificada, obrigando-o a suportar as situações jurídicas passivas que seu estado de sócio lhe impõe (idem, p. 188-189).

159 D. C. GONÇALVES, Fusão, cisão e transformação... cit., p. 184.

160 Até 1969, admitia-se apenas que fossem atribuídas ações, valores mobiliários ou obrigações da sociedade incorporadora como contraprestação às ações extintas. Posteriormente, diversas legislações americanas passaram a prever também a possibilidade de pagamento em dinheiro em espécie e outros bens, incluindo ações de outra sociedade (vide Cf. S. H. SCHULMAN; A. SCHENK, Shareholders' voting and appraisal rights in corporate acquisition transactions, 38 Bus Law, 1982-1983, disponível em: <http://heinonline.org>, acesso em: 11 mar. 2012, p. 1531-1532).

161 Ainda assim, existem operações no mercado brasileiro em que, em vez de serem atribuídas apenas ações aos acionistas da incorporada, foram também conferidos bônus de subscrição da sociedade incorporadora, sendo que uma parcela do patrimônio líquido da incorporada foi utilizada para pagamento do preço de aquisição do bônus de subscrição e contabilizada como reserva de capital na incorporadora, como disposto no art. 182, $\S 1 .^{\circ}, b$, da Lei das S.A. Vide, por exemplo, incorporações da DR7 Participações e Empreendimentos Ltda. e Ralah Participações e Empreendimentos Ltda. pela Brasil Insurance Participações e Administração S.A., ambas aprovadas em 26.06.2013. 
Diferentemente do que existe em terreno americano e europeu, ${ }^{162}$ não há na lei brasileira nenhuma previsão para o tratamento das frações de ações no contexto das operações de incorporação, tendo a CVM também já se manifestado que as frações de ações não podem ser desconsideradas. ${ }^{163}$ A única disposição na Lei das S.A. que cuida do problema das frações de ações é o $§ 3 .^{\circ}$ do art. 169, que trata da hipótese de capitalização de lucros ou reservas, mandando vender em bolsa as ações que não puderem ser atribuídas. $^{164}$

$\mathrm{Na}$ prática, as companhias têm seguido os preceitos do art. 169 da Lei das S.A. ${ }^{165}$ ou previsto que os acionistas controladores atribuam suas frações de ações para possibilitar que os minoritários recebam uma ação inteira. ${ }^{166}$

Outro ponto interessante se refere à existência de relações de troca variáveis entre a data de assinatura do protocolo e o fechamento da operação. Em Delaware, para lidar com a flutuação do valor das ações entre a assinatura do contrato de fusão (merger agreement) e a conclusão da operação, é possível estabelecer uma relação de troca flutuante que considere essa variação de preço. Em geral, as companhias estipulam parâmetros dentro dos quais o preço das ações pode flutuar e uma fórmula para calcular a quantidade de ações da incorporadora que serão recebidas na conclusão da operação. Uma

162 Em Delaware o contrato de fusão geralmente prevê o pagamento em dinheiro para frações de ações, mas não há impedimento para outras formas de pagamento em vista das diversas contraprestações admitidas sob essa legislação (vide S. M. BAINBRIDGE, Mergers and Acquisitions... cit., p. 78). Na legislação europeia, vimos que existe a possibilidade de pagamento de parcela em dinheiro, que é utilizada justamente para o ajuste das frações de ações.

163 Cf. Processo CVM n. RJ 2001/6951, rel. Dir. Wladimir Castelo Branco Castro, j. 01.11.2001.

164 Lei das S.A.: “Art. 169. O aumento mediante capitalização de lucros ou de reservas importará alteração do valor nominal das ações ou distribuições das ações novas, correspondentes ao aumento, entre acionistas, na proporção do número de ações que possuírem. [...] § 3. ${ }^{\circ}$ As ações que não puderem ser atribuídas por inteiro a cada acionista serão vendidas em bolsa, dividindo-se o produto da venda, proporcionalmente, pelos titulares das frações; antes da venda, a companhia fixará prazo não inferior a 30 (trinta) dias, durante o qual os acionistas poderão transferir as frações de ação".

165 A título exemplificativo, vide "Ata de Assembleia Geral do Banestes S.A. - Banco do Estado do Espírito Santo", de 17.01.2012; "Protocolo e Justificação de Incorporação de Ações de Emissão da Raia S.A. pela Drogasil S.A.", de 24.10.2011; "Instrumento Particular de Protocolo e Justificação de Incorporação de Ações da Companhia Leste Paulista de Energia na CPFL Energia S.A.”, de 28.10.2009; "Protocolo e Justificação de Incorporação do Banco do Estado do Piauí S.A. pelo Banco do Brasil S.A.", de 10.11.2008; "Protocolo e Justificação de Incorporação de Ações de Emissão da Eleva Alimentos S.A. pela Perdigão S.A.", de 13.11.2007; e "Protocolo e Justificação de Incorporação de Ações de Emissão da Companhia Brasileira de Petróleo Ipiranga pela Ultrapar Participações S.A.”, de 09.11.2007.

166 Por exemplo, "Protocolo e Justificação de Incorporação da Isar Holding Ltda." celebrado com a Porto Seguro S.A., em 10.11.2009. Vide também C. TOMAZELlA, Proteção de acionistas e credores... cit., p. 73. 
fórmula comum de conversão é a seguinte: o número de ações da incorporada detido por um acionista é multiplicado por um fator que é determinado dividindo-se o valor total do que valeriam as ações da incorporadora na data de assinatura do contrato de fusão pela média do valor de bolsa de tais ações em determinado período (exemplo, últimos 30 dias antes da conclusão da operação), sendo o produto obtido por essa multiplicação a quantidade de ações que cada acionista deveria receber. Essa mesma fórmula, em geral, também estabelece limites máximos e mínimos no número de ações que poderão ser emitidas. ${ }^{167}$ Também existem casos em que a relação de troca (principalmente em cash out mergers) sofre acréscimos em favor dos acionistas da incorporada como modo de incentivar a incorporadora a concluir todas as etapas da transação negociada e realizar o fechamento da operação, que são as chamadas ticking fees. ${ }^{168}$ Como veremos no item 2.2.1, dada a liberdade para escolha dos critérios que determinam a relação de troca de acordo com a Lei das S.A., entendemos que algumas soluções semelhantes poderiam ser admitidas em solo nacional.

\subsubsection{Inexistência de Relação de Substituição}

Em geral, as operações de incorporação de sociedades implicam aumento de capital na sociedade incorporadora com a consequente emissão de ações da incorporadora conforme a relação de substituição de ações acordada.

No entanto, a incorporação de sociedade sem aumento de capital não descaracteriza a operação porque, como já dissemos, são figuras jurídicas distintas e não é da essência da incorporação o aumento de capital. ${ }^{169}$ Tanto no caso de incorporação de subsidiária integral quanto na hipótese de incorporação de sociedade por sua subsidiária integral, caso ocorram por valor patrimonial, não haverá aumento de capital na incorporadora nem alterações nos percentuais de participação dos acionistas e, portanto, não será necessário estabelecer uma relação de troca entre as ações. No primeiro caso, as

167 Cf. S. M. BAINBRIDGE, Mergers and Acquisitions... cit., p. 78.

168 Cf. D. E. WOLF, Kirkland \& Ellis LLP, Time is money - ticking fees, disponível em <http://blogs.law.harvard.edu/corpgov/2013/10/18/time-is-money-ticking-fees/>, acesso em: 14 nov. 2013.

169 Cf. A. LAMY Filho; J. L. BulhõEs PedReIRA (Coord.), Direito das companhias, v. 2, cit., p. 1785. Da mesma maneira, expõem E. L. TeIXEIRA; J. A. TAVARES GUERREIRO, Das Sociedades Anônimas... cit., p. 670. 
ações da subsidiária incorporada detidas pela incorporadora serão substituídas diretamente pelos ativos e passivos da incorporada vertidos por meio da incorporação. No segundo caso, as ações da subsidiária integral detidas pela sociedade incorporada serão canceladas ou colocadas em tesouraria, conforme faculta o art. 224, IV, da Lei das S.A., sendo substituídas pela mesma quantidade de ações da incorporadora que serão atribuídas diretamente aos sócios da incorporada, na proporção do capital social que cada um deles detinha.

Além disso, a necessidade de se estabelecer uma relação de troca de ações também não depende da figura do aumento de capital. Exemplos dessa hipótese são os casos em que a incorporadora detém ações em tesouraria suficientes para atribuir aos acionistas que ingressam no seu quadro acionário ou aqueles casos em que os acionistas da incorporada controlada exercem seu direito de recesso. Nesses casos, não há aumento de capital, mas há necessidade de se estabelecer uma relação de troca para a operação.

Uma segunda hipótese a ser abordada refere-se à incorporação de sociedades deficitárias ou cujo patrimônio seja igual a zero. ${ }^{170} \mathrm{~A}$ incorporação de sociedade com patrimônio líquido negativo não foi expressamente prevista pela nossa legislação societária, mas também não foi vedada, havendo, inclusive, importantes manifestações a seu favor. Entre elas, destacamos o Parecer Conjur/MICT n. 29, de 26.12.1996 ${ }^{171}$ e também manifestações da CVM no sentido de que a existência de patrimônio líquido negativo não necessariamente impede que ocorra a incorporação, desde que seja adequadamente tratada na formação do capital. ${ }^{172}$

No entanto, há, nesses casos, uma questão relevante a ser resolvida em relação ao aumento de capital e à emissão de novas ações pela sociedade incorporadora: como a incorporação não acarretaria um aporte positivo na sociedade incorporadora, não haveria como justificar o aumento de capital e a emissão de novas ações aos acionistas da

170 Veja que nesses casos não estamos tratando de sociedades cujo patrimônio líquido contábil seja negativo, mas que, por força da utilização de outros métodos de avaliação, passe a representar um ativo com valor devidamente lastreado. Essas situações, a princípio, não apresentariam desafios adicionais e permitiriam que as operações de incorporação fossem concluídas normalmente.

171 Publicado no DOU de 09.01.1997.

172 Vide PAS CVM n. 10/2000, rel. Dir. Luiz Antonio de Sampaio Campos, j. 08.07.2004; e M. C. DE CASTRO NEVES, Incorporação de sociedade... cit., p. 114. 
sociedade incorporada ou àqueles que teriam suas ações incorporadas, o que também acarretaria uma ausência de relação de troca de ações. Nesse sentido, se o valor do patrimônio líquido da sociedade incorporada é zero ou negativo, não há patrimônio líquido para a formação do capital da sociedade sucessora desse patrimônio e a sociedade só poderia ser realizada com a extinção das ações sem sua substituição. ${ }^{173}$ Nesses casos, entende-se que a incorporação da sociedade deficitária é realizada para o seu saneamento financeiro. ${ }^{174}$

A dificuldade nesse caso está na impossibilidade de justificar um aumento de capital na sociedade incorporadora com a emissão de novas ações aos acionistas da sociedade incorporada. Ao contrário, a incorporação de uma sociedade deficitária poderia, inclusive, gerar uma redução de capital na sociedade incorporadora caso essa não tivesse lucros ou reservas suficientes para fazer frente à diminuição do seu patrimônio. Ou seja, apesar de as operações de incorporação no Brasil terem como um dos seus principais efeitos a atribuição de ações aos novos acionistas, não seria coerente haver atribuição de ações ao acionista da sociedade deficitária incorporada. ${ }^{175}$ Vimos, no entanto, que a figura do aumento de capital não é essencial à incorporação e que a participação dos sócios no capital social da incorporadora pode, em algumas situações, ser afastada. Nesses casos, portanto, não haveria relação de troca a ser negociada e os acionistas da incorporada não receberiam nem ações da incorporadora nem valor algum em função da conclusão da operação. $^{176}$

Por outro lado, no que se refere às operações de incorporação de ações, o aumento de capital parece ser obrigatório. Nos termos do $§ 1 .^{\circ}$ do art. 252 da Lei de S.A., a integração entre os acionistas da incorporadora e os acionistas que tiveram suas ações incorporadas se dá por meio do aumento de capital da sociedade incorporadora com a concomitante integralização de tal aumento mediante entrega das ações a serem

\footnotetext{
173 Cf. A. LAMY FILHO; J. L. BUlHões PedREIRA (Coord.), Direito das companhias, v. 2, cit., p. 1768.

174 Vide C. TOMAZElla, Proteção de acionistas e credores... cit., p. 119.

175 Idem, ibidem, p. 121.

176 C. TOMAZELla faz um paralelo com a hipótese de dissolução e liquidação de uma companhia nessa situação. Tais matérias poderiam ser decididas pelo mesmo quórum de maioria absoluta necessário para aprovação da incorporação da sociedade e, em tais casos, os acionistas não receberiam nenhum valor da sociedade na partilha de ativos. Dessa maneira, parece ser admissível que no caso de uma operação de incorporação também nada seja atribuído a tais acionistas (Proteção de acionistas e credores... cit., p. 122). Quanto à controvérsia relativa à essencialidade da participação dos sócios da incorporada na nova sociedade, vide o que dissemos no item 2.1.3 acima.
} 
incorporadas. ${ }^{177}$ N. EIZIRIK entende, nesse sentido, que o aumento de capital da companhia incorporadora decorre da incorporação de ações como ato complementar, fundamental e necessário à consumação da incorporação de ações, objetivando criar novas ações para serem entregues aos acionistas da companhia cujas ações foram incorporadas. ${ }^{178}$ No mesmo sentido, A. XAVIER defende que o aumento de capital é da essência da figura da incorporação de ações. ${ }^{179}$

Se houver efetivamente obrigatoriedade de aumento de capital, a questão da inexistência de relação de substituição de ações não existiria para as operações de incorporação de ações como aconteceria no caso das incorporações de sociedade deficitária. O problema aqui gira também em torno de se admitir que as ações a serem incorporadas possam ser avaliadas por valor equivalente a zero e, por isso, incorporadas sem que resultem aumento de capital para a incorporadora. Diferentemente do patrimônio de uma sociedade a ser incorporada, que corresponde a uma universalidade de direitos composta de direitos e obrigações pecuniários, as ações de uma sociedade não poderiam ter valor inferior a zero, ainda mais considerando a limitação de responsabilidade dos acionistas de uma sociedade anônima. Por essa razão, a hipótese de uma incorporação de ações sem aumento de capital aconteceria na remota hipótese de que as ações fossem avaliadas com valor equivalente exatamente a zero, situação bem mais incomum do que pode ocorrer na incorporação de sociedades. Embora em teoria essa situação não seja inadmissível, na prática dificilmente ocorreria o que, associado aos termos da lei, faz com que as incorporações de ações de fato só ocorram com aumento de capital na sociedade incorporadora e consequente estipulação de uma relação de troca de ações.

177 Lei das S.A.: “Art. 252 [...] $\S 11^{\circ}$ A assembléia-geral da companhia incorporadora, se aprovar a operação, deverá autorizar o aumento do capital, a ser realizado com as ações a serem incorporadas e nomear os peritos que as avaliarão; os acionistas não terão direito de preferência para subscrever o aumento de capital, mas os dissidentes poderão retirar-se da companhia, observado o disposto no art. 137, II, mediante o reembolso do valor de suas ações, nos termos do art. 230".

179 Incorporação de ações: natureza jurídica e regime tributário... cit., p. 123. Vide também C. M. M. SCHLIECKMANN, Aspectos societários da incorporação de ações... cit., p. 14. 


\subsubsection{Relação de Troca e Outros Valores Mobiliários}

Nas operações de incorporação surge certa dúvida sobre o tratamento a ser conferido a determinados valores mobiliários como as ações de fruição e a outros títulos híbridos ou conversíveis, como bônus de subscrição, partes beneficiárias e debêntures.

No caso de incorporações de sociedades, existe um tratamento especial conferido às debêntures emitidas pela sociedade incorporada previsto no art. 231 da Lei das S.A. De acordo com a previsão legal, a incorporação de companhia emissora de debêntures não poderá ocorrer antes de ser obtida a prévia aprovação dos debenturistas, a não ser que seja assegurado aos debenturistas que assim o desejarem o resgate de suas debêntures nos termos do $\S 1 .^{\circ}$ do mesmo art. 231. Aos debenturistas da sociedade incorporadora, não há tratamento especial previsto pela lei, cabendo a eles apenas o direito de oposição previsto no art. 232 da Lei das S.A. ${ }^{180}$

Quanto aos demais títulos especiais que conferem alguma espécie de participação nos lucros ou direito de conversão em ações aos seus titulares, como partes beneficiárias ou bônus de subscrição, diferentemente do que ocorre nas legislações estrangeiras, ${ }^{181}$ não há na Lei das S.A. nenhuma previsão específica sobre como eles deverão ser tratados no contexto de uma incorporação de sociedade. Aos titulares de tais títulos, portanto, resta apenas o direito de oposição como conferido a qualquer credor no contexto de operações de incorporação. ${ }^{182}$

Maiores dificuldades se apresentam ainda quando os títulos em questão, sejam eles debêntures, partes beneficiárias ou bônus de subscrição, são incompatíveis com o novo

180 É bem verdade que as escrituras de emissão de debêntures, no mais das vezes, já regulam os efeitos decorrentes de eventual operação de incorporação envolvendo a sociedade, de modo que, em geral, outras consequências são verificadas além daquelas previstas em lei.

181 Seguindo orientação do art. 15 da Diretiva 2011/35, as legislações europeias introduziram regras especiais para tratamento dos titulares de tais títulos com direitos especiais. Vide, exemplificativamente, o art. 101-D do Código de Sociedades Comerciais de Portugal e arts. 31-4 e 41-2 da Ley 3/2009 da Espanha. De acordo com as linhas gerais estabelecidas pela Diretiva 2011/35, os titulares de tais títulos devem ter na sociedade incorporadora direitos ao menos equivalentes àqueles que tinham na sociedade incorporada, salvo se a modificação de tais direitos tiver sido aprovada por uma assembleia dos portadores desses títulos (caso assembleia para tais títulos esteja prevista) ou individualmente por cada titular, ou ainda se esses portadores tiverem o direito de obter da sociedade incorporante o resgate de seus títulos.

182 Vide C. TOMAZElla, Proteção de acionistas e credores... cit., p. 156-157. 
tipo societário da sociedade resultante da incorporação. Nesses casos, o ideal seria que o próprio estatuto ou a escritura de emissão de tais títulos trouxessem previsão das consequências nas hipóteses de incorporação. Caso isso não ocorra, entendemos que o mais lógico seria que fosse oferecido aos titulares de tais títulos o resgate ou a conversão antecipada. $^{183}$

De qualquer maneira, em todos os casos em que tais títulos não forem resgatados, entendemos que a determinação da relação de troca deverá levar em conta a existência de tais títulos, seja porque foram antecipadamente convertidos e, portanto, seus titulares tornaram-se acionistas da companhia, seja porque a possibilidade futura de novos acionistas entrarem na sociedade certamente influenciará a distribuição dos resultados futuros e dos poderes políticos conferidos aos sócios das sociedades no momento da concretização da operação. Assim, como ensina A. VICARI, a presença de títulos conversíveis obriga as sociedades que emitiram tais títulos a deliberarem, no contexto da elaboração do projeto de fusão, uma modificação na relação de conversão de tais títulos sobre a base estabelecida pela relação de troca das ações. ${ }^{184}$ No mesmo sentido, C. TOMAZELLA entende que o protocolo deveria indicar o tratamento a ser dado aos titulares de tais títulos. ${ }^{185}$

Já no caso de uma operação de incorporação de ações, a exclusão de valores mobiliários híbridos justifica-se facilmente por uma interpretação literal do art. 252 da Lei das S.A., que fala exclusivamente em ações, sem incluir eventuais direitos de subscrição, debêntures conversíveis ou partes beneficiárias. Além disso, a razão técnica pela qual a lei restringe as operações de incorporação de ações somente às ações subscritas está ligada diretamente à estimativa que se faz da incorporada para fins de estabelecimento do valor de aumento de capital da incorporadora e determinação da relação de troca de ações. Nessas operações, o capital social da incorporada é que exerce papel central, e é por essa razão que o art. 252 da Lei das S.A. fala em "incorporação de todas as ações do capital social”. ${ }^{186}$

\footnotetext{
183 No mesmo sentido, vide C. TOMAZElla, Proteção de acionistas e credores... cit., p. 187.

184 Cf. A. VICARI, Gli Azionisti nella Fusione di Società, Milano: Giuffrè, 2004, p. 136.

185 Proteção de acionistas e credores... cit., p. 54.

186 Cf. E. F. DE PONTES, Incorporação de ações no direito brasileiro... cit., p. 66.
} 
Dessa maneira, não estão incluídos nas operações de incorporação de ação eventuais direitos de subscrição ou valores mobiliários estranhos ao capital social como, por exemplo, debêntures conversíveis, bônus de subscrição ou partes beneficiárias. Essas obrigações se mantêm perante a nova subsidiária integral mesmo após a conclusão da operação e, no caso de títulos convertidos, podem até mesmo afetar o status de subsidiária integral da incorporada. ${ }^{187}$

Não obstante, a existência de tais títulos pode afetar os valores da relação de troca das ações que serão afetadas pela operação de incorporação de ações. Em primeiro lugar, porque, caso a relação de troca tenha sido baseada puramente no valor de avaliação de tais ações, é de esperar que a existência de títulos conversíveis ou que dão direito aos resultados da companhia já tenha sido considerada e computada ao valor das ações. Além disso, mesmo que a relação de troca leve em conta outros fatores que não exclusivamente o valor das ações sendo incorporadas, a existência de quaisquer desses títulos deveria afetar a relação de troca, dado que eles poderão interferir na fruição pela incorporadora dos benefícios econômicos e políticos decorrentes das ações incorporadas.

No que tange às ações de fruição, a dúvida que surge é se, tendo sido integralmente amortizadas, integrariam ou não as operações de incorporação de ações. Entendemos nesse ponto que as ações amortizadas devem fazer parte do objeto das incorporações de ações como o restante das ações do capital social. Isso porque, como a amortização de ações no Brasil se opera sem que haja redução de capital (nos termos do § 2. ${ }^{\text {do art. }} 44$ da Lei das S.A.), na verdade, apesar do nome amortização, não chega a ser caracterizada uma liquidação antecipada da companhia, pois claramente o capital social não é afetado. ${ }^{188} \mathrm{O}$ acionista é, portanto, reembolsado, ${ }^{189}$ mas mantém o direito de continuar na companhia e de participar dos resultados futuros e do acervo patrimonial da companhia se houver sobras em eventual liquidação. Dada a natureza das ações de fruição no Brasil, entendemos que tais ações devem, sim, participar dos processos de incorporação

187 Idem, ibidem, p. 65-68.

188 Nesse sentido, vide M. CARvalhosa, Comentários à Lei de Sociedades Anônimas, v. 1, cit., p. 524; e E. F. DE PONTES, Incorporação de ações no direito brasileiro... cit., p. 67-68.

189 A natureza dos pagamentos a título de amortização não é isenta de controvérsias. Alguns os veem como natureza de dividendos e outros, com os quais concordamos, como reembolso de entradas. A discussão em questão é abordada de modo mais aprofundado em E. F. DE PONTES, Incorporação de ações no direito brasileiro... cit., p. 70-73. 
de ações. É possível, porém, que o acionista fruicionista tenha um desconto considerável na relação de troca de suas ações, até mesmo pelo fato de a amortização afetar o valor patrimonial da ação por se tratar de ação privilegiada que antecipou preferências no tempo. ${ }^{190}$

\subsection{Determinação da Relação de Substituição de Ações}

O modo da regulamentação da relação de substituição de ações pode variar significativamente de uma legislação societária para outra. Pode, por exemplo, ser considerada fora da autonomia contratual das partes e constituir mera declaração imposta às sociedades, cujo conteúdo vem já previamente disciplinado pela legislação ou, em sentido diametralmente oposto, pode ser encarada como elemento estritamente negocial das operações e sujeita à liberdade contratual das partes, aproximando-se mais à figura do preço de aquisição de um contrato de compra e venda. ${ }^{191}$

Se se entende que a determinação da relação de troca é como um "preço", sujeito à liberdade contratual das partes, tende-se a dar validade a qualquer tipo de incorporação independentemente das consequências aos demais sócios e, com isso, permite-se que a maioria possa dispor livremente dos direitos da minoria sem nenhuma limitação. No entanto, como vimos no item 2.1.1 acima, a relação de substituição não se trata propriamente de um preço negociado individualmente por cada um dos acionistas de acordo com seu interesse individual, e sim de uma substituição de bens a eles imposta nos termos do protocolo da operação aprovado pela maioria dos acionistas em assembleia, cujo requisito de validade está, portanto, sujeito ao atendimento de certos critérios e balizas impostas pela lei para permitir a redistribuição do patrimônio social entre os acionistas.

Por outro lado, aqueles que consideram que a determinação da relação de troca não deve ser objeto de nenhuma negociação, em geral, amarram o efeito da diluição da participação dos acionistas decorrente da conclusão dessas operações com o valor da participação originária de tais acionistas em cada uma das sociedades, em geral considerando o valor patrimonial das ações, de tal modo que esse valor originário é

\footnotetext{
190 Cf. Idem, ibidem, p. 73.

191 Nesse sentido, vide A. PÉREZ TroyA, La determinación... cit., p. 23-25 e 75-76; e C. TOMAZELLA, Proteção de acionistas e credores... cit., p. 64.
} 
utilizado como parâmetro para determinar o realinhamento das participações societárias na nova sociedade. Nesses casos, entende-se que os sócios devem receber na nova sociedade um valor idêntico àquele conferido por suas participações primitivas antes da conclusão da operação como modo de se ter uma operação justa, sendo inadmitidas atribuições de valor atual inferiores àquelas que antes detinham, ainda que com maiores possibilidades de rentabilidade no futuro. ${ }^{192}$ A vantagem dessa segunda posição é que ela impede que a maioria dos sócios possa dispor a seu livre-arbítrio da participação dos minoritários, mas, ao mesmo tempo, pode obstar que se realizem incorporações que, ainda que exijam um sacrifício patrimonial imediato, possam maximizar o valor da participação no futuro em função dos benefícios decorrentes da operação. ${ }^{193}$ É evidente também que essa posição tem sérias dificuldades em determinar qual seria o valor que deveria ser garantido aos acionistas pós-conclusão da operação, quais os critérios considerados para avaliação e o que estaria incluído nesse valor, como, por exemplo, expectativas futuras da sociedade ou apenas o valor patrimonial simulando a liquidação das sociedades naquele momento.

Em vista das dificuldades acima, é comum que as legislações adotem uma posição intermediária e eclética, segundo a qual se deve considerar o valor das participações dos acionistas ao mesmo tempo que se admite certa discricionariedade na determinação da relação de troca porque estariam mesclados nessa negociação fatores e critérios de índole objetiva e subjetiva, bem como elementos econômicos e extraeconômicos. ${ }^{194}$

O que em geral se vê, portanto, é que as legislações reconhecem a influência de fatores não econômicos nas operações de incorporação, como a habilidade de negociação das sociedades envolvidas em determinar a relação de troca que melhor lhe convenha, ao mesmo tempo que impõem certos limites e exigem critérios que justifiquem a relação de troca negociada. ${ }^{195}$ Dessa maneira, definem-se procedimentos que devem ser obrigatoriamente seguidos para determinação da relação de substituição e,

192 Vide F. ViCEnT CHUlí, apud A. PÉREZ TROYA, La determinación... cit., p. 24.

193 Idem, ibidem. É de questionar também se essa interpretação não levaria a uma subordinação do interesse social ao interesse de determinados acionistas, impedindo uma operação que traria benefícios no longo prazo.

194 Cf. R. LARgo Gil, apud A. PÉrez Troya, La determinación del tipo de canje... cit., p. 25. A possibilidade de outros fatores negociais entrarem em cena na definição da relação de troca e na extensão da obrigação de manutenção do valor para os acionistas será discutida mais adiante.

195 Vide C. TOMAZELla, Proteção de acionistas e credores... cit., p. 64. 
simultaneamente, preserva-se a liberdade das partes para determinar os termos e as condições dessas operações dentro de certos parâmetros. Assim, protegem-se os acionistas minoritários de uma redistribuição expropriatória das suas participações e, concomitantemente, permite-se a realização de operações que seriam impedidas caso a manutenção de certo valor de participação fosse condição para a validade de uma operação. $^{196}$

Em linha com esse posicionamento, a Diretiva 2011/35 entende que a determinação da relação de troca das ações é de competência dos administradores, mas exige, ao mesmo tempo, que seja divulgada uma série de informações, relatórios e demonstrações financeiras das companhias.

O art. 5. ${ }^{\circ}$ da Diretiva 2011/35 prevê que os administradores ou órgãos de direção das sociedades envolvidas elaborem um projeto escrito de fusão. Nesse projeto deve constar, obrigatoriamente, a relação de troca de ações e, se for o caso, a quantia em dinheiro atribuída aos acionistas. ${ }^{197}$

Em seguida, o art. 9..$^{\circ}$ da Diretiva 2011/35 impõe que os órgãos da administração ou de direção de cada uma das sociedades participantes na fusão elaborem um relatório escrito pormenorizado, explicando e justificando do ponto de vista jurídico e econômico o projeto de fusão assinado pelos órgãos de direção e administração das sociedades que participaram da fusão e, em especial, a relação de troca das ações. $\mathrm{O}$ relatório deve indicar ainda dificuldades especiais de avaliação, caso existam. ${ }^{198}$

196 A. PÉREZ TROYA, La determinación del tipo de canje... cit., p. 25.

197 “Art. 5. $^{-1}$. Os órgãos de administração ou de direcção das sociedades que participam na fusão elaboram um projecto escrito de fusão. 2. O projecto de fusão deve indicar, pelo menos: a) O tipo, a denominação e a sede social das sociedades participantes na fusão; b) A relação de troca das acções e, se for caso disso, a quantia em dinheiro atribuída aos accionistas; c) As modalidades de entrega das acções da sociedade incorporante; d) A data a partir da qual essas acções conferem o direito aos dividendos, bem como qualquer especialidade relativa a esse direito; e) A data a partir da qual as operações das sociedades incorporadas serão consideradas, do ponto de vista contabilístico, efectuadas por conta da sociedade incorporante; f) Os direitos assegurados pela sociedade incorporante aos accionistas que gozem de direitos especiais e aos portadores de títulos diferentes das acções, ou as medidas propostas relativamente a eles; g) Todas as vantagens especiais atribuídas aos peritos referidos no n. 1 do art. $10 .^{\circ}$ e aos membros dos órgãos de administração, de direcção, de vigilância ou de fiscalização das sociedades participantes na fusão."

198 “Art. 9. - 1. Os órgãos de administração ou de direcção de cada uma das sociedades participantes na fusão elaboram um relatório escrito pormenorizado, explicando e justificando do ponto de vista jurídico 
Na França, as previsões do art. 9. ${ }^{\circ}$ da Diretiva 2011/35 são seguidos pelo artigo R-236-5 do Code de Commerce, exigindo que o conselho ou diretoria explique o projeto de fusão de maneira detalhada do ponto de vista jurídico e econômico, notadamente no que tange à relação de troca e aos métodos de avaliação utilizados, os quais deverão ser consistentes com as sociedades avaliadas. Na Itália, o art. 2501-quater do Codice Civile exige que os administradores das sociedades participantes da fusão redijam relatório que ilustre do ponto de vista econômico e jurídico o projeto de fusão e, em especial, a relação de troca das ações, indicando os critérios de determinação da relação de troca e eventuais dificuldades na avaliação. Previsões equivalentes se encontram no art. 33 da Ley 3/2009 da Espanha, no art. 908 do Companies Act britânico, no art. 14 da Legge Federalle sulla fusioni, la scissione, la trasformazione e il trasferimento di patrimonio na Suíça e no art. 98/1.(e) e 3 do Código das Sociedades Comerciais de Portugal.

A exigência desses relatórios tem o intuito de fornecer aos acionistas informações completas e efetivas sobre a incorporação a ser aprovada, detalhando e esclarecendo os aspectos legais como, por exemplo, o funcionamento e os órgãos administrativos que compõem a companhia adquirida, e também os aspectos econômicos da operação, como a avaliação e o potencial econômico da companhia com quem se realiza a operação. Esse último esclarecimento, evidentemente, é fundamental para se determinar a relação de troca a ser estabelecida entre as empresas participantes da operação já que é ele que irá permitir avaliar o futuro desempenho da nova sociedade a ser formada, bem como possibilitar a comparação entre os patrimônios das duas companhias envolvidas.

Note-se, no entanto, que de todas as informações que devem ser prestadas pela administração, a única explicação e justificação que vem expressamente mencionada nos termos da Diretiva 2011/35 é aquela relativa à determinação da relação de troca das ações, a qual deve ser detalhadamente explicada do ponto de vista jurídico e econômico. ${ }^{199} \mathrm{~A}$ justificação de uma operação de incorporação deverá, portanto, necessariamente se basear sobre um duplo pronunciamento da administração: um mais genérico, que se refere à própria decisão de incorporação, e outro mais particular, que diz respeito exclusivamente à relação de troca. Isso não significa que sejam necessárias duas justificações independentes

e económico o projecto de fusão e, em especial, a relação de troca das acções. O relatório deve indicar, além disso, as dificuldades especiais de avaliação, caso existam. [...]."

199 Cf. European Communities Commission, Report on the Draft Convention... cit., p. 48. 
sob tais legislações, dado que existe uma relação íntima e inextricável entre a manifestação específica da relação de troca e a justificação da operação em si, pois é precisamente a relação de substituição proposta que determinará o grau de alteração do status quo dos sócios decorrentes da conclusão da operação de incorporação. Assim, para atendimento das exigências da Diretiva 2011/35, não seria suficiente uma justificação genérica da operação, sendo necessário, em qualquer caso, justificar que a participação concreta de cada sócio atribuída na sociedade resultante pós-operação não constitui uma redistribuição de recursos dos sócios de caráter expropriatório. ${ }^{200}$

Além dessa justificação detalhada da relação de troca, como veremos mais aprofundadamente no item 2.2.3 abaixo, o art. 10 da Diretiva 2011/35 exige que peritos independentes examinem o projeto de fusão e redijam relatório escrito destinado aos acionistas, declarando se, em sua opinião, a relação de troca é justa e razoável.

As previsões do art. 10 da Diretiva 2011/35, por sua vez, são seguidas, por exemplo, na Itália pelo art. 2501-sexies do Codice Civile, o qual exige que um ou mais peritos para cada sociedade elaborem relatório sobre a equidade da relação de troca, indicando o método ou métodos usados para a determinação da relação de substituição proposta e os valores resultantes da aplicação de cada um deles, bem como as dificuldades de avaliação. O relatório também deve conter um parecer sobre a adequação do método ou métodos utilizados para a determinação da relação de troca e a importância relativa atribuída a cada um deles na determinação do valor adotado. Os mesmos requisitos surgem em outros países como no art. 34 da Ley 3/2009 da Espanha, no artigo L 236-10 do Code de Commerce francês e art. 99/4 do Código das Sociedades Comerciais de Portugal.

Vê-se, assim, que, embora a Diretiva 2011/35 entenda que os administradores têm liberdade para negociar os termos da relação de troca, há uma preocupação especial em garantir que essa relação de troca seja amplamente justificada e divulgada pela administração e que os métodos utilizados para determiná-la sejam depois atestados por peritos independentes como justos e adequados para aquele caso, inclusive com a indicação da pertinência e da importância relativa do método utilizado para determinação da relação de troca.

200 Cf. A. PÉREZ TROYA, La determinación del tipo de canje... cit., p. 77. 
As diretrizes acima são seguidas, com algumas variações, por todos os países europeus analisados por este estudo, sendo umas ou outras mais ou menos restritivas no que tange à determinação da relação de troca. Legislações como as da Suíça e Espanha têm previsões mais rigorosas quanto à determinação da relação de troca, pois ambas exigem que ela esteja baseada no "valor real do patrimônio" das sociedades envolvidas e que os acionistas da incorporada recebam ações da incorporadora em proporção à sua antiga participação na incorporada tendo em conta o patrimônio das sociedades envolvidas. ${ }^{201}$ Ao contrário, a legislação francesa parece dar maior liberdade quanto ao modo e à vinculação da relação da substituição das ações, já que estipula que a aquisição da qualidade de sócios da sociedade resultante da operação se dá “dans le condition determinées par le contrat de fusion ou de scission". 202

Por sua vez, em Delaware, a negociação de uma operação de incorporação, incluindo a fixação da relação de substituição de ações, é deixada a critério da administração das sociedades, a qual é incumbida de negociar todos os termos da operação de acordo com o business judgment rule. ${ }^{203-204}$ Também não é expressamente exigida pela lei a interferência de peritos para avaliar algum aspecto da operação. ${ }^{205}$

201 Vide (i) Suíça - Art. 7 da Legge Federalle sulla fusioni, la scissione, la trasformazione e il trasferimento di patrimonio, que dispõe que os acionistas da sociedade incorporada têm direito a ações ou direitos corporativos no seio da sociedade incorporadora correspondentes às ações ou aos direitos detidos previamente, levando em conta o patrimônio das sociedades que se fundem, a repartição dos direitos de voto e quaisquer outras circunstâncias relevantes; e (ii) Espanha - arts. 24-1 e 25-1 da Ley $3 / 2009$ que estabelecem que os sócios das sociedades extintas se integrarão na sociedade resultante da fusão, recebendo um número de ações ou participações, ou uma quota, na proporção das suas respectivas participações naquelas sociedades e que a relação de troca se determinará sobre a base do valor real do patrimônio social. Ainda assim, veremos mais à frente, quando discutirmos os parâmetros de determinação das relações de troca, que nem mesmo tais previsões aparentemente mais rigorosas solucionam o problema por completo e tampouco eliminam o caráter negocial da sua determinação.

202 Code de Commerce: "Article L236-3 I. - La fusion ou la scission entraîne la dissolution sans liquidation des sociétés qui disparaissent et la transmission universelle de leur patrimoine aux sociétés bénéficiaires, dans l'état où il se trouve à la date de réalisation définitive de l'opération. Elle entraîne simultanément l'acquisition, par les associés des sociétés qui disparaissent, de la qualité d'associés des sociétés bénéficiaires, dans les conditions déterminées par le contrat de fusion ou de scission". No mesmo sentido, vide opinião de D. C. GONÇALVES, Fusão, cisão e transformação... cit., p. 136.

Vide S. M. BAINBRIDGE, Mergers and Acquisitions... cit., p. 57.

204 De origem jurisprudencial, o business judgment rule é regra norte-americana por meio da qual se presume que os administradores de uma companhia atuam com boa-fé, de maneira informada e no interesse social, de modo que os tribunais devem se abster de rever o mérito das decisões da administração. Para que as decisões da administração fiquem sujeitas ao critério do business judgment rule é preciso que se verifiquem alguns pressupostos: (i) exercício de julgamento pelo administrador, que deve sempre escolher praticar ou não praticar determinada medida, mas nunca abster-se de decidir; (ii) ausência de conflito de interesses entre a decisão sendo tomada e o administrador; (iii) ausência de 
Dessa maneira, a proteção dos acionistas na regulação da relação de troca repousa sobre os direitos fiduciários dos administradores, mais precisamente pela atuação dos administradores de boa-fé e de modo informado, com base em toda a documentação disponível, buscando o que acreditam ser o melhor para a companhia que administram e o melhor preço para os acionistas, ${ }^{206}$ associado ainda a amplo acesso a um Poder Judiciário eficiente e que facilita a contestação de tais operações pelos minoritários insatisfeitos. ${ }^{207}$ Nas operações de incorporação, os administradores devem buscar o melhor preço para as ações da incorporada, sendo que essa obrigação é verificada com base em dois componentes principais: (i) suficiência da informação à qual a administração teve acesso para apurar o real valor da companhia; e (ii) estruturação da operação de modo que o valor de aquisição da companhia incorporada tenha se aproximado o máximo possível do valor apurado. $^{208}$

$\mathrm{Na}$ verdade, sob as leis e decisões de Delaware, grande parte da proteção conferida aos acionistas em operações de incorporação se deve ao mecanismo dos appraisal rights conferidos pela lei. ${ }^{209}$ Os appraisal rights são uma espécie aproximada de direito de retirada com o intuito de possibilitar que os acionistas com direito de voto que

fraude ou ilegalidade; (iv) existência de alguma racionalidade econômica ou de negócios para a decisão; e (v) decisão informada (process due care), tomada de acordo com um processo adequado. Caso um acionista decida contestar a atuação da administração, caberá a ele o ônus de provar que os administradores, naquele determinado ato, agiram sem boa-fé ou em violação aos seus deveres de diligência e lealdade (cf. S. M. BAINBRIDGE, Mergers and Acquisitions... cit., p. 60-61; M. V. VON ADAMEK, Responsabilidade civil dos administradores de S/A e as ações correlatas, São Paulo: Saraiva, 2010, p. 129-131). Em alguns casos, porém, como veremos mais adiante no item 3.2, o critério de revisão de uma decisão de incorporação pode não ser a business judgment rule.

Como veremos no item 2.2.3 abaixo, embora não haja exigência expressa na lei, a contratação de peritos pelas companhias de Delaware é, no entanto, comum.

206 O requisito de se tomar uma decisão informada (process due care) analisando toda a informação que esteja disponível aos administradores foi especialmente importante no caso Smith v. Van Gorkom, Del. Supr. 488 A.2d 858 (Del. 1985). Esse polêmico caso, julgado em 1985, é ainda um dos principais parâmetros de discussão sobre os deveres fiduciários da administração, notadamente sob a óptica do business judgment rule e do dever de tomada de decisões informadas, tendo criado uma doutrina mais rigorosa em relação aos administradores com postura negocial mais agressiva ao sustentar que a business judgment rule não significa um escudo de proteção contra decisões mal informadas (vide S. M. BAINBRIDGE, Mergers and Acquisitions... cit., p. 64-65; R. ClARK, Corporate Law, Boston, Toronto: Little, Brown and Company, 1986, p. 128-129). No mesmo sentido, M. V. VON ADAMEK, Responsabilidade civil... cit., p. 129.

207 Operações dessa natureza podem ser contestadas por class actions no direito americano, o que barateia o custo desse tipo de contencioso para o acionista insatisfeito, isentando-o também do custo de advogados que serão remunerados com uma porcentagem dos danos apurados. Vide S. M. BAINBRIDGE, Mergers and Acquisitions... cit., p. 65; J. H. CHOPER; J. C. COFFEE, JR.; R. J. GILSON, Cases... cit., p. 984.

209 Vide DGCL $\$ 262$. 
manifestem sua dissidência a operações de fusão ou incorporação (as statutory mergers) realizem o desinvestimento por seu valor justo, recebendo o valor proporcional de sua participação na companhia antes de concretizada a operação (salvo certas exceções em que tal direito não se aplica). ${ }^{210}$ Exercido tal direito, o acionista dissidente deverá receber o valor justo de suas ações apurado em juízo sem considerar as perdas ou os ganhos decorrentes da transação ou eventuais descontos em razão de as ações serem de participação minoritária. ${ }^{211}$ Em direito americano, como discutiremos ao longo deste trabalho, os appraisal rights têm importante papel na recomposição do equilíbrio de uma operação de fusão, sendo uma possível estratégia de regulação dos interesses envolvidos nas operações de incorporação em lugar das típicas ações de responsabilidade ou simulações de negociações independentes.

Feita essa análise preliminar da regulamentação da relação de troca em outras legislações, passaremos a analisar os procedimentos impostos pela legislação brasileira e os possíveis limites estabelecidos à determinação da relação de troca no Brasil, sem deixar de compará-los de maneira mais sistemática com a regulação estrangeira quando pertinente.

210 Vide S. M. BAINBRIDGE, segundo quem os appraisal rights "give the shareholders who dissented from a merger the right to have the fair value of their shares determined and paid to them in cash, provided the shareholders comply with the convoluted statutory procedures" (Mergers and Acquisitions... cit., p. 97); R. CLARK segue na seguinte linha: "corporate statutes often give a shareholder who dissents from a certain major corporate transaction the right to be bought out by the company at a price reflecting the value of his shares as determined in a judicial proceeding. Typically, this right of appraisal is given in connection with mergers, sales or exchanges of substantially all assets of the corporation, and charter amendments that materially and adversely affect the rights of the dissenting shareholder" (Corporate Law... cit., p. 443). Vide também J. C. COFFEE, Jr., Transfer of Control and the Quest for Efficiency: Can Delaware Law Encourage Efficient Transactions while Chilling Inefficient Ones?, 21 Del. J. Corp. L. 359, 1996, p. 363; e D. KALANSKY, Incorporação de ações... cit., p. 60.

211 Os métodos de avaliação podem ser os mais diversos, mas é bastante famoso o Delaware Block Method, que considera três fatores de maneira isolada ou conjunta: preço de mercado, patrimônio líquido a preço de mercado e rentabilidade futura, embora esse método já seja considerado atualmente um pouco defasado desde a decisão da Suprema Corte de Delaware no caso Weinberger v. UOP (vide F. H. EASTERBROOK; D. R. FISCHEL, The economic structure of corporate law, Cambridge: Harvard University Press, 1996, p. 145; K. HOEFSTETTER, One size does not fit all: Corporate Governance for "Controlled Companies", Revised Draft, Harvard Law School, June 20, 2005 disponível em: <http://papers.ssrn.com/sol3/papers.cfm?abstract_id=802705>, acesso em: 17 ago. 2013, p. 48). 


\subsubsection{Critérios para Fixação da Relação de Substituição}

A primeira menção à relação de substituição das ações na Lei das S.A. aparece no inciso I do art. 224 da Lei das S.A., na disciplina geral das operações de incorporação. $^{212}$ De acordo com esse artigo, devem ser divulgados no protocolo de incorporação o número, a espécie e a classe das ações que serão atribuídas em substituição dos direitos de sócios que se extinguirão e os critérios utilizados para determinar as relações de substituição. Essa é a exigência feita pela legislação nacional em relação à determinação e à divulgação da relação de substituição de ações que, por constituir o elemento essencial das operações de incorporação, deve vir claramente definida no protocolo com o intuito de possibilitar que os acionistas avaliem a operação e formem juízo sobre a sua conveniência. Em seguida, a questão da relação de troca é tratada também no âmbito da justificação por meio dos incisos II e III do art. 225 da Lei das S.A. ${ }^{213}$

A Lei das S.A. não explicita a que se referem esses critérios para determinação da relação de troca das ações, mas a maior parte da doutrina entende tratar-se dos critérios de avaliação dos patrimônios das sociedades envolvidas que levaram à determinação da relação de substituição de ações. ${ }^{214}$

Os métodos de avaliação comumente utilizados para se determinar o valor de uma companhia são os seguintes: valor contábil, valor patrimonial a preços de mercado, cotação de bolsa das ações e fluxos de caixa futuros descontado. No entanto, tais critérios de avaliação de companhias são bastante discutíveis, com riscos envolvidos em cada um deles e podem ser estabelecidos de diversas maneiras, sendo que os próprios estudiosos de

212 Lei das S.A.: “Art. 224. As condições da incorporação, fusão ou cisão com incorporação em sociedade existente constarão de protocolo firmado pelos órgãos de administração ou sócios das sociedades interessadas, que incluirá:

I - o número, espécie e classe das ações que serão atribuídas em substituição dos direitos de sócios que se extinguirão e os critérios utilizados para determinar as relações de substituição; [...]".

213 Lei das S.A.: “Art. 225. As operações de incorporação, fusão e cisão serão submetidas à deliberação da assembléia-geral das companhias interessadas mediante justificação, na qual serão expostos: [...]

II - as ações que os acionistas preferenciais receberão e as razões para a modificação dos seus direitos, se prevista;

III - a composição, após a operação, segundo espécies e classes das ações, do capital das companhias que deverão emitir ações em substituição às que se deverão extinguir; [...]”."

214 Cf. A. LAmy Filho; J. L. Bulhões PedreiRA (Coord.), Direito das companhias, v. 2, cit., p. 17631764; N. EIZIRIK, A Lei das S/A comentada... cit., p. 226; e L. SILVA, O valor justo em incorporação de sociedade controladas, São Paulo: Almedina, 2011, p. 53-54. 
finanças podem ter dificuldade em determinar qual o critério mais adequado para apurar o valor de uma companhia em um caso concreto. ${ }^{215}$

O critério contábil, por exemplo, pode se justificar para companhias recémconstituídas e não operacionais, mas é muitas vezes criticado pelos seguintes fatores: contabilização de acordo com o princípio da competência e não caixa (o que pode tornar a contabilidade desbalanceada em alguns aspectos), relatórios contábeis com custos históricos, contas registradas por valor futuro (como as contas a receber), ativos possivelmente subestimados, ativos intangíveis não contabilizados e existência de muitas operações que não se refletem nas demonstrações financeiras (off-balance sheet). ${ }^{216}$ Por essa razão, o valor contábil é raramente utilizado para avaliação das companhias no mercado de capitais.

O valor de patrimônio líquido a preços de mercado é um método que busca simular o valor da companhia que seria obtido em uma liquidação ordenada, considerando cada item do ativo e do passivo da companhia mensurado, individualmente, por seu possível valor de venda ou reposição, a exemplo do que ocorreria na hipótese de liquidação, com exceção do goodwill que não é considerado para esse fïm. ${ }^{217}$ Esse critério pode ser favorável quando o valor patrimonial da companhia for superior ao valor da companhia em marcha, pois considera os benefícios líquidos futuros que o conjunto de ativos e passivos poderia gerar. No entanto, esse critério é muitas vezes considerado inadequado para avaliar uma companhia porque não considera o valor do negócio em funcionamento, restringindo-se aos seus ativos e passivos como se houvesse uma liquidação da companhia. ${ }^{218}$ Além disso, esse critério é menos representativo em sociedades cujo valor esteja baseado em ativos intangíveis que não constam no balanço,

215 Cf. A. DAMODARAM, Investment Valuation: Tools and Techniques for determining the Value of Any Asset. 2. Ed., New York: Wiley Finance, 2002, p. 1-2. Como se sabe, a ciência das finanças não é uma ciência exata e nem promete revelar o verdadeiro valor de uma companhia, pois as informações e premissas que levam ao cálculo do valor de uma companhia são dotadas de subjetivismo. No mesmo sentido, vide E. MARTINS, ao dizer que o valor de uma companhia depende tanto da companhia sendo analisada como do sujeito que promove a avaliação (Avaliação de empresas: da mensuração contábil à econômica, 5. ed., São Paulo: Atlas, 2006, p. 264).

216 L. SILVA, $O$ valor justo... cit., p. 66.

217 Cf. PAS CVM 08/05, rel. Dir. Eli Loria, j. 12.12.2007. No mesmo sentido, TJSP, 4. ${ }^{\text {a }}$ Câm., AC 219.3854/2, rel. Des. José Geraldo de Jacobina Rabello, j. 26.06.2008; e TJSP, 4. ${ }^{a}$ Câm., AC 516.357-4/0, rel. Des. José Geraldo de Jacobina Rabello, j. 26.06.2008; e L. SILVA, O valor justo... cit., p. 69.

218 Cf. voto da presidente Maria Helena dos Santos no julgamento do PAS CVM n. 25/03, rel. Dir. Eli Loria, j. 25.03.2008. 
como é o caso, por exemplo, de empresas prestadoras de serviço, nas quais o valor está principalmente alocado no posicionamento de mercado, carteira de clientes, know-how, marca etc.

A avaliação da companhia pelo valor das cotações de suas ações realiza-se pela multiplicação do número de ações existentes pelo valor da cotação de tais ações no mercado, a qual, em tese, refletiria o valor presente do fluxo de caixa da companhia dividido pelo número de ações da companhia. ${ }^{219}$ Esse critério é considerado por muitos como o mais perfeito, já que o valor apurado não decorre da opinião de um avaliador apenas, mas de todo o conjunto de participantes do mercado, o que lhe confere maior grau de objetividade. ${ }^{220}$ No entanto, a utilização desse critério só é válida em um mercado de valores mobiliários desenvolvido e eficiente, no qual haja um sistema de informação eficaz entre companhia e investidores e no qual determinada ação tenha alto índice de negociabilidade, pois, nesses casos, todas as informações sobre a companhia emitente, bem como sobre as ações emitidas, são de conhecimento do público e refletidas no preço das ações. $^{221}$ Caso o patrimônio sendo avaliado não seja representado por ações com negociações continuadas e em volume suficiente para que sejam representativas, o critério da cotação em bolsa perde sua justificativa perante os demais modos de avaliação do patrimônio. Esse motivo é o que fundamenta, por exemplo, a proibição de uso do critério de cotação em bolsa nas operações de incorporação envolvendo companhia aberta a não ser que referidas ações integrem índices gerais representativos de carteiras admitidas em negociação conforme dispõe a ICVM $319 .{ }^{222}$

Considerando que o atual mercado de capitais brasileiro não é perfeito e que nem todas as ações nele negociadas compõem índices que reflitam um alto grau de liquidez, é preciso ter cuidado e avaliar se o critério da cotação em bolsa realmente é o melhor parâmetro para a avaliação do valor de uma companhia. Além disso, outro cuidado necessário na adoção do critério de cotação de bolsas é eliminar variações atípicas do valor

219 Cf. F. H. EASTERBRoOK; D. R. FISChel, The Economic Structure... cit., p. 154; e L. SILVA, O valor justo... cit., p. 69.

220 Nesse sentido, o Parecer de Orientação CVM n. 5, de 3 de dezembro de 1979, adverte que o real valor econômico da ação que tem liquidez de mercado é determinado pela cotação de mercado. Nesse mesmo sentido, vide N. EIZIRIK, A Lei das S/A comentada... cit., p. 241.

221 A mesma lógica se aplica à fundamentação do preço de emissão de novas ações com base na cotação de bolsa das ações, conforme exposto no Parecer de Orientação CVM n. 1, de 27 de setembro de 1978.

222 Nesse sentido, vide N. EIZIRIK, A Lei das S/A comentada... cit., p. 241. 
da ação, até mesmo aqueles advindos do próprio anúncio da operação. Por essa razão, é comum encontrar nos protocolos a utilização da cotação média dos últimos 60 ou 90 noventa dias anteriores ao fechamento da operação.

Por fim, o critério do fluxo de caixa descontado consiste, em resumo, em avaliar a companhia de acordo com os fluxos de caixa livre futuros por ela gerados trazidos a valor presente por determinada taxa de desconto. ${ }^{223}$ Esse critério pode ser bastante relevante nas hipóteses em que as ações da companhia não são negociadas no mercado ou nos casos em que, mesmo num mercado eficiente, tenham ocorrido mudanças nas perspectivas das ações sem que delas tenha o mercado pleno conhecimento ou assimilado devidamente. ${ }^{224}$ Porém, mesmo sendo o critério mais recomendado pela literatura recente e tido como fundamental para apurar o valor de uma companhia, ${ }^{225}$ por ser um método de avaliação baseado na expectativa futura de geração de caixa de uma companhia, diversos fatores subjetivos entram em jogo nessa avaliação, tanto em relação aos prognósticos de geração de caixa das companhias como em relação à taxa de desconto a ser utilizada. Por essa razão, esse é o método de avaliação que pode gerar mais divergência entre os avaliadores $^{226} \mathrm{e}$, nesse contexto, administradores e avaliadores podem ser incentivados a agir de maneira oportunista em favor de uma das partes ou, até mesmo, em benefício do controlador em operações entre partes relacionadas. ${ }^{227}$

Há ainda uma série de outros métodos de avaliação de companhias à disposição da administração, como valor presente de dividendos, P/L de ações similares, capitalização de lucros, múltiplos de faturamento, múltiplos de fluxo de caixa, valor presente do Economic Value Added (EVA) e tantos outros modelos que tomam como base o fluxo de caixa descontado. ${ }^{228}$ Assim como os métodos mais comuns mencionados acima, esses critérios de avaliação têm seus prós e contras e também estão, em maior ou menor grau, sujeitos à subjetividade dos avaliadores e são passíveis de manipulação, sendo necessária

223 Cf. A. DAMODARAM, Investment Valuation... cit., p. 11-12.

224 Cf. Parecer de Orientação CVM n. 1, de 27 de setembro de 1978.

225 Cf. E. MARTins (ORG.), Avaliação de empresas... cit., p. 275.

226 F. H. EASTERBROOK e D. R. FISCHEL afirmam que esse método de avaliação é notoriamente incerto em função da estimativa positiva ou negativa do fluxo de caixa e da taxa de desconto que refletirá o risco do negócio a ser utilizada (The economic structure... cit., p. 155).

227 Vide nesse sentido L. SILVA, $O$ valor justo... cit., p. 73.

228 Vide nesse sentido E. MARTins (ORG.), Avaliação de empresas... cit., p. 265-284; e L. SILVA, O valor justo... cit., p. 73-74. 
uma avaliação minuciosa por parte da administração da companhia em cada caso concreto sobre qual critério escolher.

Feito esse breve exame dos possíveis critérios a serem utilizados para avaliação de companhias e dos principais riscos envolvidos em cada um deles, é importante aprofundarmos a análise do inciso I do art. 224 da Lei das S.A. que trata especificamente sobre a relação de troca das ações. De acordo com esse artigo, o protocolo deve estabelecer "o número, espécie e classe das ações que serão atribuídas em substituição dos direitos de sócios que se extinguirão e os critérios utilizados para determinar as relações de substituição". A análise atenta da redação desse artigo nos leva a três importantes conclusões, expostas a seguir.

A primeira delas é que não há na Lei das S.A. nenhuma exigência legal ou determinação especial quanto aos critérios de avaliação a serem utilizados para a determinação das relações de substituição, os quais poderão ser escolhidos livremente pelos administradores e acionistas das sociedades envolvidas de acordo com seu melhor entendimento e levando em conta o que entendem ser melhor para o atendimento do interesse social. ${ }^{229-230}$

A segunda conclusão é que, em nenhum momento, a Lei das S.A. exigiu que os patrimônios das sociedades envolvidas fossem avaliados pelo mesmo método para determinação da relação de substituição de ações, de modo que uma sociedade pode ser avaliada, por exemplo, pelo método do fluxo de caixa descontado, enquanto outra é avaliada pelo valor de suas ações no mercado. A definição do critério escolhido constitui, portanto, matéria negocial, prevalecendo a liberdade de contratar das companhias, cujas vontades serão expressas em assembleias gerais dos acionistas. A Procuradora Federal Especializada da CVM também se manifestou de acordo com esse entendimento por meio do Memo/PFE-GJU/186/04, de 3 de agosto de 2004, dizendo que a adoção dos parâmetros,

229 Cf. N. EIZIRIK, Temas de direito societário, Rio de Janeiro: Renovar, 2005, p. 321. Vide também PAS CVM n. 24/04, rel. Dir. Eli Loria, j. 31.07.2007, ao dizer que "em uma incorporação comum, os critérios de avaliação utilizados não encontram, em princípio, obstáculos legais e podem ser decididos pelos sócios ou administradores das sociedades".

230 Existem casos em que as avaliações são realizadas, inclusive, com base nas regras de avaliação e no registro de legislações estrangeiras, como foi o caso da incorporação interjurisdicional da Jantus S.L., sociedade espanhola, pela CPFL Energias Renováveis S.A., companhia aberta brasileira, aprovada em 26.03.2013 
tanto para avaliar o patrimônio da incorporada quanto para estabelecer a relação de troca, é informada pelo princípio da liberdade contratual e livremente pactuada pelas partes, sendo ainda possível o emprego de mais de um critério como modo de se alcançar um valor justo. $^{231}$

Por fim, a terceira conclusão que se tira da leitura do artigo é que, embora a maior parte da doutrina associe os critérios de determinação da relação de substituição de ações com os critérios de avaliação de cada uma das companhias, a Lei das S.A. jamais mencionou que tais critérios se referem, exclusivamente, à avaliação das respectivas companhias de maneira individualizada ou dos respectivos patrimônios como fez no caso do art. 226, esse, sim, mencionando a avaliação do patrimônio que formará o capital social da incorporadora.

Assim, é possível que outros critérios sejam levados em consideração. Entre eles, por exemplo, conforme lecionam A. LAMY FILHO e J. L. BULHÕES PEDREIRA, as projeções dos benefícios resultantes da unificação das sociedades envolvidas nas operações de incorporação e a consequente distribuição desses benefícios entre os acionistas das sociedades envolvidas, considerando a situação das sociedades após a conclusão da operação. $^{232}$

Incorporada e incorporadora podem, portanto, negociar a relação de troca que entenderem ser melhor, ainda que tal relação de troca não seja efetiva e diretamente baseada nas avaliações dos patrimônios das sociedades envolvidas e independentemente dos critérios de avaliação escolhidos para determinação do valor das respectivas sociedades. Por essa razão, a incorporada pode negociar procurando o melhor "preço", que pode ser, inclusive, menor que o valor de avaliação do seu patrimônio. A incorporadora, por sua vez, pode até "pagar" mais que o valor da avaliação apurado, pois pode incluir em

231 Cf. N. EIZIRIK, A Lei das S/A comentada... cit., p. 226; Vide também Processo CVM n. RJ 2007/4933, rel. SEP, j. 19.06.2007, em que o Colegiado confirmou a possibilidade de adoção de critérios diferenciados para fixação da relação de troca entre incorporadora e incorporada, caso em que para o Banco do Brasil S/A (incorporadora) foi utilizado o critério da cotação das ações no mercado de valores mobiliários, enquanto para o Banco do Estado de Santa Catarina S.A. e do BESC S.A. Crédito Imobiliário (incorporadas) foi aplicado o critério do fluxo do caixa descontado. Posteriormente, o Colegiado da CVM volta a confirmar esse ponto em nova consulta do Banco do Brasil S.A. no caso de incorporação do Banco do Estado do Piauí S.A. conforme Processo CVM n. RJ 2007/13175, rel. SEP, j. 12.11.2007.

232 Direito das companhias, v. 2, cit., p. 1764. 
sua análise fatores estranhos à companhia quando isoladamente analisada (economia de custos, poder de mercado, patentes complementares, liderança etc.). ${ }^{233}$

Neste tópico, vale relembrarmos ainda a interpretação das regras de avaliação para fixação do preço de emissão de novas ações conforme os critérios estabelecidos no $\S$ $1^{\circ}$ do art. 170 da Lei das S.A. (valor patrimonial, perspectivas de rentabilidade futura e cotação no mercado) aplicáveis aos aumentos de capital. ${ }^{234}$ Para esse propósito, a Lei das S.A. também não previu nenhuma obrigatoriedade na escolha de um ou outro critério, sendo facultado aos avaliadores utilizá-los de maneira isolada ou em conjunto com um dos demais critérios previstos pela legislação. ${ }^{235}$ A interpretação dominante desse dispositivo é que tais critérios não devem ser compreendidos como elementos estanques e absolutamente objetivos, e sim como parâmetros, balizas de orientação e elementos indicativos que devem ser levados em consideração pela administração para a fixação do preço de emissão de novas ações. $^{236}$

233 A ideia de que a negociação da relação de troca é baseada no princípio da liberdade contratual e não está diretamente ligada ao valor de avaliação das respectivas companhias consideradas de maneira isolada foi descrita de modo brilhante no voto do Diretor Pedro Oliva Marcilio de Sousa no âmbito do Processo CVM n. RJ 2007/4933, rel. SEP, j. 19.06.2007, que disse: "a Lei 6.404/76 não estabelece a necessidade de prévia avaliação das companhias, para que se determine a relação de substituição em incorporação de ações. Essa é uma decisão 'arbitrária', em sua acepção técnica, das administrações, que, no estabelecimento da relação de substituição, devem levar em conta o interesse das companhias que administram. [...] Assim, o incorporado pode negociar procurando o melhor 'preço', que pode ser, inclusive, menor que o preço pelo fluxo de caixa descontado ou o valor de mercado, desde que o processo de negociação tenha sido justo e desinteressado. Isso se dá, inclusive, porque a incorporação será decidida pelos próprios acionistas e não pela administração. (..) A incorporadora, por seu turno, pode até 'pagar' mais que o valor justo ou a avaliação pelo fluxo de caixa descontado ou o valor de mercado, pois pode incluir em sua análise fatores extracompanhia analisada isoladamente (economia de custos, poder de mercado, patentes complementares, liderança, etc...). O que importa, aqui, também, é um processo de negociação justo e desinteressado".

234 Tais critérios são utilizados de modo que as novas ações em aumento de capital sejam emitidas pelo seu valor econômico, evitando uma diluição injustificada dos acionistas que não exerceram seu direito de preferência, conforme exposto na própria exposição justificativa do anteprojeto da Lei das S.A.

235 Essa questão, inclusive, foi objeto do Parecer de Orientação CVM n. 1, de 27 de setembro de 1978, que, ao analisar a possiblidade de aplicação isolada ou cumulativa desses fatores para determinação do preço de emissão, entendeu que, em cada caso concreto, deverá haver prevalência de um dos três parâmetros sobre os demais, conforme o estágio de desenvolvimento do mercado de ações, bem como em função do comportamento de determinada ação no mercado (índice de negociabilidade).

236 Vide, por exemplo, M. R. PENTEADO ao dizer que "[s]obre esse problema, as opiniões acabaram por convergir para a interpretação de que os critérios constantes do dispositivo legal citado são "elementos indicativos', que devem ser justificadamente 'ponderados' para a fixação do preço de emissão" (Aumentos de capital das sociedades anônimas, São Paulo: Saraiva, 1988, p. 173). No mesmo sentido, E. L. TEIXEIRA e J. A. TAVARES GUERREIRO ensinam que "[o]s três fatores mencionados no questionado preceito servem como parâmetros para a fixação do preço de emissão, sem que um prepondere necessariamente sobre os demais" (Das sociedades anônimas no direito brasileiro... cit., p. 156-157). 
Dessa maneira, a utilização da expressão "tendo em vista" no art. 170, § 1. ${ }^{\circ}$, da Lei das S.A. confere à administração da companhia discricionariedade para fixar o preço de emissão das ações no aumento de capital, desde que não se promova uma diluição injustificada dos acionistas minoritários, ${ }^{237}$ sendo esse também o entendimento manifestado pela CVM. ${ }^{238}$ Além disso, a autarquia já decidiu que os critérios estabelecidos pela Lei das S.A. no art. 170, § 1. ${ }^{\circ}$, são meramente indicativos, sem que necessariamente vinculem a administração, acrescentando ainda que os laudos de avaliação eventualmente elaborados para determinar o valor de emissão da ação também não são vinculantes. ${ }^{239}$ A autarquia chegou a permitir, inclusive, que o preço de emissão de certas ações fosse baseado não no valor do laudo de avaliação da companhia, e sim em função da negociação independente entre os acionistas e credores da companhia que teriam sua dívida convertida em capital. ${ }^{240}$

Ora, se para a definição do preço de novas ações em aumentos de capital, para os quais a lei expressamente previu determinados critérios visando a impedir a diluição injustificada dos acionistas que não exercerem seu direito de preferência, a doutrina e a CVM têm entendido que existe ampla margem de discricionariedade conferida à administração, entendemos que essa margem de discricionariedade é ainda mais ampla nos

237 ' '[a] expressão legal 'tendo em vista' deve ser sublinhada. Ela não indica uma determinação precisa, do tipo 'pela média de tais e tais valores', ou então, 'por este ou aquele valor'. O 'ter em vista', no caso, significa levar em consideração, ou ter em conta; o que importa em conferir ao órgão societário que fixa o preço de emissão de ações uma certa latitude de apreciação, ou um perímetro decisório. Estamos, pois, diante de um poder discricionário, no sentido técnico da expressão em direito administrativo, poder esse delimitado por diretivas legais", cf. F. K. COMPARATO, A fixação do preço de emissão das ações no aumento de capital da sociedade anônima, Revista de Direito Mercantil Industrial, Econômico e Financeiro, n. 81, São Paulo: RT, 1991, p. 85. Também nesse sentido: "nenhuma lei jamais poderia impor um preço, ou um critério único para fixá-lo, tantas são as variáveis que influem, ou podem influir nessa decisão de mercado. Essa é zona da discricionariedade do administrador, e da assembleia geral, de seu direito de escolher entre alternativas, de tomar decisões que nenhuma lei pode invadir, pois são ditadas pelo mercado, sob pena de esclerosar a atividade econômica" (cf. A. LAMY FILHO, J. L. BUlHÕES PEDREIRA, A Lei das S.A. - Parte III - Pareceres, v. II, 2. ed., Rio de Janeiro: Renovar, 1996, p. 466-467). Ainda conforme esse entendimento: “o texto [do art. 170, $\S 11^{\circ}$ ] não contém um comando, de forma imperativa, pois se refere a três referenciais diversos, nunca coincidentes, contendo, apenas, parâmetros deixados à livre apreciação das empresas" (cf. A. LAMY FILHO; J. L. BULHÕES PEDREIRA, $A$ Lei das S.A. - Parte III - Pareceres... cit., p. 490). Conforme voto do então Presidente Marcelo Trindade no Processo CVM n. RJ 2004/3098, 25.01.2005.

Cf. Processo CVM n. RJ 2004/5476, rel. Dir. Marcelo Trindade, j. 01.03.2005, “o laudo, por si só, não é vinculante para a determinação do preço das novas ações, tendo em vista que outros fatores poderão ser também levados em consideração, o que se verificará caso a caso, e deverá, sempre, constar da proposta de aumento". No mesmo sentido vide PAS CVM n. RJ 2009/8316 ao dizer que "não há regra, na lei ou na regulamentação da CVM, que imponha a necessária adstrição do preço de emissão com a cifra exata do Laudo de Avaliação".

240 Vide PAS CVM n. RJ 2009/8316. 
casos de operações de incorporação, para os quais nem mesmo a indicação dos critérios de determinação da relação de troca a lei cuidou de indicar. Assim, julgamos ser plenamente defensável a utilização de um ou outro critério, a cumulação de um ou mais critérios e até mesmo a introdução de outros critérios que não estejam diretamente ligados à avaliação das companhias como geralmente comentado pela doutrina.

Como se vê, existe ampla liberdade para determinação da relação de troca das ações e da escolha dos critérios que a justificam, sendo o texto legal amplo o suficiente para possibilitar que aqueles que negociam o protocolo de incorporação encontrem o que melhor se ajusta para a avaliação das companhias e para a operação do ponto de vista negocial.

No entanto, apesar dessa liberdade, não se pode conceber que essas definições sejam realizadas de maneira totalmente arbitrária e injustificada pelos administradores das companhias.

Em primeiro lugar, a liberdade conferida aos administradores para deliberar sobre as relações de troca não os autoriza a escolher determinado critério que não tenha relação nenhuma com a companhia envolvida ou com as ações de sua emissão. ${ }^{241}$

Em segundo lugar, os administradores devem sempre ter em mente os prós e contras de cada método de avaliação das companhias, estando obrigados a justificar a pertinência do método escolhido e ter em consideração os riscos envolvidos em cada um deles, conforme discutimos acima. A verdade é que não é possível afirmar que apenas um critério é o mais adequado para todo e qualquer tipo de situação, porque não existem verdades absolutas nesse campo. Como vimos, nem mesmo o critério do fluxo de caixa descontado está livre de contestações dada a imensa subjetividade das projeções que serão utilizadas, de modo que apenas a análise casuística cotejada com a justificativa da administração é que poderá determinar se os critérios escolhidos foram ou não adequados e se acarretam ou não prejuízos indevidos aos acionistas minoritários. ${ }^{242}$

241 Cf. N. EIZIRIK, A Lei das S/A comentada... cit., p. 226.

242 Vide nesse sentido, N. EIZIRIK, A Lei das S/A comentada... cit., p. 226; e L. SILVA, O valor justo... cit., p. 75 . 
No mesmo sentido, a CVM já se manifestou dizendo que, em cada caso, devese buscar a adoção do critério que melhor avalie cada companhia envolvida e que, independentemente de os critérios adotados serem os mesmos ou não entre a sociedade incorporada e incorporadora, o que é fundamental é que os administradores das companhias envolvidas entendam e justifiquem que os critérios escolhidos são os que melhor avaliam as respectivas companhias. ${ }^{243}$

Em geral, nas companhias abertas, as avaliações propostas para deliberação das assembleias gerais se baseiam em estimativas de resultados futuros elaborados por empresas especializadas, ${ }^{244}$ mas, normalmente, o que se vê nas operações de incorporação é que a relação de troca propriamente dita é bem pouco justificada, contento apenas uma menção de que foi determinada mediante negociação independente entre as partes e, quando muito, justificada com base em uma confrontação simples entre o patrimônio da sociedade incorporadora e da incorporada. No entanto, além dos critérios escolhidos para efetuar a avaliação das companhias isoladamente consideradas, é necessário verificar se tais critérios são efetivamente suficientes para determinar a relação de troca proposta, pois é possível que ela não esteja baseada exclusivamente no laudo de avaliação das companhias isoladamente consideradas, mas também leve em conta as projeções dos benefícios resultantes da unificação das sociedades envolvidas nas operações de incorporação e a distribuição desses benefícios entre os sócios. Nesses casos, além da mera justificativa dos critérios escolhidos para avaliação das companhias, é fundamental que sejam esclarecidos que fatores são esses e que seja justificado o modo de rateio de tais benefícios entre os acionistas, explicitando os critérios que levaram à determinação da relação de substituição proposta para a operação e não apenas aqueles relativos à avaliação de cada companhia.

A importância e a necessidade de se realizar essa análise, além daquela relativa apenas aos patrimônios de cada uma das sociedades, serão analisadas com mais profundidade neste trabalho no item que aborda a justificação da operação e a comprovação de atendimento do interesse social.

\footnotetext{
243 Cf. Processo CVM n. RJ 2007/4933, rel. SEP, j. 19.06.2007.

244 Cf. A. LAMY FILho; J. L. BulhÕes PEdREIRA (Coord.), Direito das companhias, v. 2, cit., p. 1764.
} 


\subsubsection{Avaliação de Patrimônio ou Ações e Formação do Capital}

Um segundo aspecto intimamente relacionado à determinação da relação de substituição de ações refere-se à obrigatoriedade das avaliações dos patrimônios das sociedades envolvidas em operações de incorporação ou, no caso das operações de incorporação de ações, das ações a serem incorporadas. ${ }^{245}$ Nesse aspecto, as legislações podem fazer maiores ou menores exigências a respeito das avaliações dos patrimônios das companhias envolvidas, bem como podem dar maior ou menor importância aos valores resultantes de tais avaliações como balizador da relação de troca das ações.

No exterior, a Diretiva 2011/35 exige a avaliação dos patrimônios de todas as sociedades envolvidas visto que a relação de troca deve ser justificada do ponto de vista econômico e jurídico em relatório escrito pormenorizado preparado pelos órgãos de administração ou direção das sociedades envolvidas (salvo se houver dispensa dessa exigência por todos os acionistas e os portadores de outros títulos que confiram direito de voto de todas as sociedades que participam da operação). Além disso, esse relatório deverá também descrever as dificuldades especiais de avaliação encontradas para determinação da relação de substituição, caso existam. ${ }^{246}$ Não há, no entanto, nenhuma obrigatoriedade de utilização de um ou outro método de avaliação nos termos propostos pela diretiva, tampouco pelas legislações nacionais, as quais apenas incorporaram as previsões genéricas que nela constavam. ${ }^{247}$

O Estado de Delaware, por sua vez, tem legislação menos exigente no que trata da avaliação dos patrimônios envolvidos, dispensando a sua obrigatoriedade para que a administração possa propor a realização de uma incorporação. No entanto, para cumprir seus deveres fiduciários, os laudos de avaliação ainda assim são contratados já que a administração deve comprovar que teve informação suficiente para apurar o real valor da

245 Cf. L. SILVA, qualquer distorção na avaliação das companhias causará o desequilíbrio da relação entre as companhias envolvidas na operação porque, nessa hipótese, para que uma parte tenha vantagem, a outra necessariamente será prejudicada ( $O$ valor justo... cit., p. 51-52). Da mesma forma, W. BULGARELLI, ensina que a avaliação dos patrimonios tem importância fundamental para determinação do valor da troca das ações e que os acionistas da sociedade absorvida podem ser prejudicados pela subavaliação, manobrada pelos controladores que recebem em contrapartida certas vantagens pessoais (Fusões, Incorporações... cit., p. 165).

246 Vide art. 9. ${ }^{\circ}$ da Diretiva 2011/35.

247 Vide D. C. GONÇALVES, Fusão, cisão e transformação... cit., p. 142. 
companhia sendo incorporada e que a operação foi estruturada levando em conta esse valor.

No Brasil, em operações entre partes independentes, as únicas exigências feitas pela Lei das S.A. em relação à avaliação de patrimônios são que (i) o patrimônio líquido vertido em formação de capital social da incorporadora seja avaliado pelos peritos nomeados em assembleia geral e que o protocolo estabeleça os critérios de avaliação desse patrimônio, bem como a data a que será referida a avaliação e o tratamento das variações patrimoniais posteriores (conforme art. 224, III, da Lei das S.A.); ${ }^{248}$ e (ii) os peritos nomeados determinem que o valor do patrimônio líquido a ser vertido para a formação do capital social da incorporadora (conforme indicado no protocolo, nos termos do inciso $\mathrm{V}$ do art. 224 da Lei das S.A.) seja, ao menos, igual ao montante do capital a realizar na incorporadora (conforme art. 226 da Lei das S.A.). ${ }^{249}$ No caso das incorporações de ações, as ações que serão entregues para formação de capital social da incorporadora devem ser avaliadas pelos peritos nomeados em assembleia geral da incorporadora de acordo com os critérios de avaliação estabelecidos no protocolo (conforme art. 252, caput e $\S 1 .^{\circ} \mathrm{c} / \mathrm{c}$ art. 224, III, da Lei das S.A.) e, embora não haja previsão expressa na lei para aplicação do art. 226 da Lei das S.A., entende-se logicamente que também nesse caso os peritos deverão determinar que o valor das ações a serem incorporadas é, no mínimo, igual ao montante do capital a realizar da incorporadora.

No item acima fizemos breve exposição sobre os diferentes critérios que podem ser utilizados para avaliação de uma companhia e os riscos envolvidos em cada um deles, sendo que tais considerações também se aplicam para a escolha do critério que será

248 Lei das S.A.: “Art. 224. As condições da incorporação, fusão ou cisão com incorporação em sociedade existente constarão de protocolo firmado pelos órgãos de administração ou sócios das sociedades interessadas, que incluirá: [...]

III - os critérios de avaliação do patrimônio líquido, a data a que será referida a avaliação, e o tratamento das variações patrimoniais posteriores".

249 Lei das S.A.: "Art. 226. As operações de incorporação, fusão e cisão somente poderão ser efetivadas nas condições aprovadas se os peritos nomeados determinarem que o valor do patrimônio ou patrimônios líquidos a serem vertidos para a formação de capital social é, ao menos, igual ao montante do capital a realizar". 
utilizado para determinação do valor do patrimônio líquido ou das ações da incorporada vertidas para a incorporadora. ${ }^{250}$

Outra questão relevante do ponto de vista prático se refere à data-base para fins de avaliação do patrimônio líquido. Embora em um cenário ideal a data-base da avaliação devesse coincidir com a data da assembleia geral que aprova a incorporação, na grande maioria das vezes não há tempo hábil para que os avaliadores consigam realizar a avaliação do patrimônio a ser incorporado na mesma data em que se realiza a assembleia. Dessa maneira, o protocolo geralmente fixa uma data passada como a data-base da avaliação e o tratamento que será dado às variações patrimoniais posteriores a essa data. ${ }^{251}$

Uma vez indicados os critérios de avaliação no protocolo e a data-base da avaliação, se os peritos consideram tais critérios adequados, deverão proceder a uma única

250 Bastante comum para esses fins é a utilização do critério contábil em razão dos efeitos tributários que decorrem da reavaliação dos bens do patrimônio caso sejam utilizados outros critérios. Apesar disso, CARVALHOSA criticou a utilização do método do patrimônio líquido por entender que colide com o princípio da justa avaliação dos patrimônios envolvidos, sendo que a verdadeira proteção dos credores estaria na avaliação real dos patrimônios envolvidos. Além disso, argumenta que a Lei das S.A. exige a avaliação pelos peritos nomeados e, no caso, a avaliação pelo balanço dispensaria em absoluto a formação do laudo e a necessidade dos peritos, tornando a disposição legal inútil e sem conteúdo (Comentários à Lei de Sociedades Anônimas, v. 4, t. I cit., p. 264). Nesse ponto, discordamos do referido autor. $\mathrm{Na}$ falta de norma legal expressa que imponha a escolha de determinado critério de avaliação, bem como diante de expressa permissão conferida pela Lei das S.A. de que as partes convencionem o critério que lhes aprouver, não vemos fundamento para impedir a adoção do critério de patrimônio líquido contábil, prescrito, inclusive, para elaboração dos balanços das próprias companhias abertas. Além disso, a avaliação com base no valor de patrimônio líquido contábil requer que os peritos verifiquem se o balanço foi elaborado com observância dos critérios legais. Por fim, a Lei das S.A. não requer uma "justa avaliação" e tampouco exige que o laudo conclua por valores determinados pelos peritos segundo os critérios de sua escolha, mas apenas que a operação poderá ser efetivada nos termos negociados, ainda que os peritos considerem por qualquer razão que o patrimônio líquido vale mais do que o convencionado no protocolo ou determinado segundo os critérios de avaliação determinado (vide A. LAMY FILHO; J. L. BUlHõES PEDREIRA (Coord.), Direito das companhias, v. 2, cit., p. 1780-1781).

251 Embora não seja obrigatório, muitas vezes se utiliza como data-base a data do mesmo balanço que será utilizado para fins de apuração do fato gerador do Imposto de Renda, isto é, balanço de no máximo 30 (trinta) dias antes da data da deliberação dos acionistas, conforme art. 21, § 1. ${ }^{\circ}$, da Lei n. 9.249/1995. M. CARVALHOSA entende que há um pressuposto fático de que a administração da sociedade incorporada ou que tenha suas ações incorporadas entre a data-base do laudo e a data de conclusão da operação será extremamente conservadora e deverá praticar apenas os atos ordinários de gestão necessários à preservação do patrimônio social. Não podem, portanto, os administradores da sociedade incorporada praticar nenhum ato de administração extraordinária que possa alterar os bens, direitos e valores do patrimônio líquido existentes na data base e que muito provavelmente afetariam também a relação de troca de ações. No caso de agirem assim, tais administradores poderão ser responsabilizados por perdas e danos causados à incorporadora. (Comentários à Lei de Sociedades Anônimas, v. 4, t. I cit., p. 272). 
avaliação e declarar se o patrimônio líquido assim apurado é ou não ao menos igual ao montante do capital a realizar da incorporadora, nos termos do art. 226 da Lei das S.A. ${ }^{252}$

Porém, caso entendam que os critérios indicados no protocolo para avaliação não são adequados para apurar o valor do patrimônio ou das ações a serem incorporadas, os avaliadores devem realizar duas avaliações: a primeira para determinar o valor convencional do patrimônio líquido ou das ações a serem incorporadas de acordo com os critérios indicados no protocolo e uma segunda avaliação para determinar o valor que consideram correto segundo os critérios que julgam mais adequados para declarar que o valor convencionado satisfaz os requisitos do art. 226 da Lei das S.A. ${ }^{253}$

Caso o valor apurado pelos peritos seja ao menos igual ao valor do capital social a realizar, a operação poderá ser concretizada nos termos propostos pela administração. Em sentido contrário, caso o valor apurado pelos peritos seja inferior ao valor do aumento de capital social constante do protocolo, a operação não poderá se concretizar e a única solução é que haja modificação no protocolo para ajustar seus termos. $^{254}$

É possível ainda que as partes convencionem que nem todo o valor do patrimônio líquido a ser vertido ou das ações a serem incorporadas seja destinado à conta de capital social. Assim, caso tais valores sejam superiores ao valor do aumento de capital da sociedade incorporadora estipulado no protocolo, a operação de incorporação em questão poderá ser concretizada nos termos do protocolo e o valor excedente poderá ser tratado como ágio destinado à formação de reserva de capital, mediante fixação do preço de emissão das ações como quociente da divisão entre o valor do patrimônio líquido apurado e o número de ações a serem emitidas. ${ }^{255}$

252 Cf. N. EIZIRIK, A Lei das S/A comentada... cit., p. 240; e A. LAMY FILHO; J. L. BULHÕES PEDREIRA (Coord.), Direito das companhias, v. 2, cit., p. 1779.

253 Cf. A. LAMY Filho; J. L. Bulhões Pedreira (Coord.), Direito das companhias, v. 2, cit., p. 1779; e A. LAMY FILHO; J. L. BUlHÕES PEDREIRA, A Lei das S.A. (pressupostos, elaboração, aplicação)... cit., p. 669-670.

254 Cf. A. LAMY FILHO; J. L. BUlhÕes PedreiRA, A Lei das S.A. - Parte III - Pareceres... cit., p. 564.

255 Cf. A. LAMY FILHO; J. L. BULHÕES PEDREIRA (Coord.), Direito das companhias, v. 2, cit., p. 1783. Não há expressa previsão legal sobre o tratamento a ser dado ao patrimônio líquido da incorporada que excede o aumento de capital da incorporadora, prevalecendo, nessa matéria, o princípio da liberdade de contratar. Por essa razão, nas incorporações de sociedades, é possível que o valor de patrimônio 
Dessa maneira, vemos que o valor atribuído pelos avaliadores não precisa, necessariamente, coincidir com o valor do aumento de capital convencionado pelas partes no protocolo de incorporação nem utilizar os mesmos critérios que levaram à determinação da relação de troca.

Assim, as sociedades participantes podem convencionar livremente os critérios que determinam a relação de troca e aqueles que serão utilizados para determinar o valor do patrimônio líquido a ser incorporado, sem que haja na lei alguma imposição para uso de um critério predeterminado como vimos no item 2.2.1 acima. Por conseguinte, pode haver dois valores diferentes de patrimônio nas operações de incorporação: o convencional, ajustado pelas partes e que, em geral, resulta de critérios acordados ao longo das negociações, e o valor determinado pelos peritos avaliadores para os fins do art. 226 da Lei das S.A. ${ }^{256}$ É possível, inclusive, que a diferença nesses valores decorra da escolha de critérios de avaliação distintos, sendo um critério de avaliação utilizado para a determinação da relação de substituição das ações e outro, exclusivamente, para fins do art. 226 da Lei das S.A. ${ }^{257}$

Em resumo, de acordo com a Lei das S.A., basta que seja prestada, no protocolo, a informação sobre um dos critérios de avaliação do patrimônio líquido da companhia incorporada ou cujas ações serão incorporadas, bem como a data de sua

incorporado que exceder o montante destinado à formação do capital seja tratado como reserva de capital ou ainda como reserva de lucros da incorporadora caso tenha sido adotado o método da incorporação linha por linha (cf. N. EIZIRIK, A Lei das S/A comentada... cit., p. 241-242). Esse método consiste em agregar aos saldos das contas da incorporadora os saldos das mesmas contas que estavam registradas no balanço da incorporada. Assim, o patrimônio líquido é vertido com a classificação que está registrada na sociedade incorporada, sendo o valor do capital social utilizado na formação do capital da incorporadora e o excesso nas mesmas contas de reservas de capital ou reservas de lucros em que estiver escriturado. Nas incorporações de ações, o valor que exceder o montante de capital deverá ser tratado como reserva de capital uma vez que a falta de extinção da companhia cujas ações são incorporadas impede a utilização do método de incorporação linha a linha.

256 Vide A. LAMY FILHO; J. L. BulHõES PEDREIRA, A Lei das S.A. (pressupostos, elaboração, aplicação)... cit., p. 669. As partes podem, ainda, apenas consignar valores estimados que ficam posteriormente sujeitos à confirmação conforme critérios determinados no protocolo, nos termos do art. 224, parágrafo único, da Lei das S.A. O valor estimado não vincula as partes, mas serve apenas para permitir o desenvolvimento dos demais itens que deverão constar do protocolo. Nesses casos, os valores finais da operação serão aqueles que os peritos determinarem de acordo com os critérios estabelecidos.

257 Vide, por exemplo, incorporação de ações da MG Polímeros pela MG Poliéster relatada no Processo CVM n. RJ 2007/8844, rel. SEP, j. 23.07.2007, na qual a relação de troca foi baseada utilizando-se o valor econômico das companhias envolvidas, enquanto o aumento de capital foi baseado no valor patrimonial da companhia incorporada. 
avaliação, para que os peritos determinem se o valor do patrimônio ou das ações a serem incorporadas é, ao menos, equivalente ao capital a realizar da incorporadora. ${ }^{258}$

A utilidade das avaliações de patrimônio ou das ações a serem incorporadas, portanto, foi limitada a garantir que o aumento de capital na incorporadora seja, de fato, integralizado com bens que correspondam ao valor do aumento de capital proposto. Nesse ponto, o foco da regulação não foi estabelecer parâmetros para determinação da relação de substituição, mas garantir efetividade ao princípio da realidade do capital social tal como ocorre na formação de capital em bens, impedindo que o patrimônio líquido incorporado ou as ações incorporadas sejam integrados ao capital social da incorporadora por valor superior ao real. ${ }^{259}$

Assim, a exigência do art. 226 da Lei das S.A. se justifica para proteção dos credores com o intuito de assegurar a integridade do capital social e evitar que terceiros que negociam com a companhia sejam induzidos em erro por conta de um valor inverídico de capital social. ${ }^{260}$ Por essa razão, estabelece o art. 226 da Lei das S.A., como condição resolutiva das operações de incorporação, a necessidade de que os peritos nomeados determinem que o valor do patrimônio líquido a ser vertido para a formação do capital social da incorporadora seja, ao menos, igual ao montante do capital a realizar, valendo o mesmo para as operações de incorporação de ações, em que o valor das ações incorporadas deve ser, no mínimo, equivalente ao valor do aumento do capital social a realizar da incorporadora. $^{261}$

258 N. EIZIRIK, A Lei das S/A comentada... cit., p. 227.

259 Nesse sentido, A. LAMY FILHO e J. L. BULHÕES PEDREIRA afirmam que a avaliação do patrimônio líquido da incorporada tem a mesma finalidade e obedece aos mesmos princípios da avaliação regulada pelo art. $8 .^{\circ}$ da Lei das S.A. referente à subscrição de capital em bens e tem como objetivo impedir que o bem forme o capital social da incorporadora por valor superior ao real. Ainda, se as partes acordarem em transferi-lo por valor inferior ao real, acrescentam os autores que não há nenhuma objeção a ser feita, pois quanto mais subavaliado estiver o bem ou o patrimônio líquido, maior é a garantia dos credores, que é a razão de ser do requisito legal de avaliação (A Lei das S.A. (pressupostos, elaboração, aplicação)... cit., p. 668-669).

260 Vide A. LAMY FILHO; J. L. BUlHÕes PEDREIRA, A Lei das S.A. (pressupostos, elaboração, aplicação)... cit., p. 669; e também em Direito das companhias, v. 2, cit., p. 1778. Da mesma maneira, M. CARVALHOSA e N. EIZIRIK ensinam que o art. 226 tem o intuito de evitar o aguamento do capital social e a emissão de ações sem lastro, ou seja, ações sem a necessária equivalência no patrimônio social, com o objetivo de proteger os interesses dos credores (Estudos de direito empresarial... cit., p. 201).

261 No caso de ações emitidas com ágio, deve-se entender que é necessário os peritos apurem que o valor do patrimônio líquido é ao menos igual ao montante resultante do preço de emissão das ações multiplicado pelo número de ações emitidas, isto é, o valor do capital social somado à reserva de capital formado com 
No que se refere à relação de troca nas operações de incorporação, no entanto, a Lei das S.A. dispensou a elaboração de qualquer laudo de avaliação por peritos para sua determinação, entendendo não ser necessário que fosse determinada mediante critérios de avaliação preestabelecidos ou com base em laudos elaborados por especialistas. A avaliação do patrimônio da incorporada ou das ações a serem incorporadas tem a finalidade de apurar o montante do aumento de capital da incorporadora e não se confunde com a fixação da relação de troca das ações dos acionistas da sociedade incorporada. ${ }^{262}$ Nesse sentido, demonstrando que o valor do aumento de capital não se relaciona com a relação de substituição de ações, CARVALHOSA e EIZIRIK ensinam que "a relação de substituição de ações dos minoritários dar-se-á com base na avaliação comparativa dos dois patrimônios, e não no montante do capital". ${ }^{263}$

Nossa Lei das S.A. tampouco estabeleceu a necessidade de que as avaliações realizadas pelos peritos compreendessem tanto o patrimônio da incorporadora como o da incorporada para determinação da relação de troca e para concretização das operações de incorporação. Para esse fim, portanto, não se confrontam os patrimônios da sociedade incorporadora e incorporada (avaliação relativa), ${ }^{264}$ de modo que não é necessário que os peritos independentes façam uma avaliação de todas as companhias envolvidas em operações de incorporação, mas apenas daquele patrimônio destinado à formação do capital da sociedade incorporadora, deixando a determinação da relação de troca aos critérios da administração ou daqueles que a negociam. ${ }^{265}$

A justificativa dada para a não exigência da avaliação relativa dos dois patrimônios é que, à míngua dessa avaliação relativa, não se desamparam os acionistas, que poderiam sempre se socorrer das regras da subscrição in natura ou ainda exercer o direito de recesso. ${ }^{266}$ No entanto, apesar de tais regras serem de fato aplicáveis, para efeitos da determinação da relação de troca, acreditamos que as regras da subscrição in natura

ágio (cf. A. LAMY Filho; J. L. BUlhões PEDREIRA (Coord.), Direito das companhias, v. 2, cit., p. 1774).

Cf. N. EIZIRIK, A Lei das S/A comentada ... cit., p. 400.

Cf. Estudos de direito empresarial... cit., p. 202.

264 E. L. TeiXeira; J. A. TAvares Guerreiro, Das Sociedades Anônimas... cit., p. 667; e L. G. P. B. LEÃES, Incorporação de companhia controlada... cit., p. 91.

265 É evidente e, na verdade, bastante usual que o protocolo estipule a avaliação dos dois patrimônios envolvidos como modo de verificação da relação de troca determinada.

266 L. G. P. B. LEÃES, Incorporação de companhia controlada... cit., p. 91. 
pouco auxiliam, pois, como vimos, o valor do aumento de capital não necessariamente corresponde ao valor utilizado para a determinação da relação de troca. O direito de recesso, por sua vez, além de limitado aos acionistas da incorporada no caso de incorporações de sociedades, tem outras limitações referentes, inclusive, ao próprio valor de reembolso, que fazem com que ele não seja considerado um mecanismo de tutela suficiente para os proteção dos acionistas minoritários. ${ }^{267}$

Por fim, a CVM também já ratificou esse posicionamento, ao afirmar que a Lei das S.A. não estabelece a necessidade de prévia avaliação das companhias para que se determine a relação de substituição em operações de incorporação. Essa é uma decisão “arbitrária”, em sua acepção técnica, das administrações, que, no estabelecimento da relação de substituição, devem levar em conta o interesse das companhias que administram. ${ }^{268}$

\subsubsection{Parecer do Conselho Fiscal ou de Peritos}

Discutidas as principais regras relativas aos critérios que determinam a relação de substituição de ações e o papel da avaliação das companhias previstas na Lei das S.A., é importante analisarmos o envolvimento de conselheiros fiscais ou peritos nas operações de incorporação como pessoas que podem analisar, de modo imparcial, a viabilidade dos termos e das condições da operação, bem como diminuir o risco potencial de que a operação seja estabelecida em critérios injustos, porém imperceptíveis para os acionistas que não têm conhecimento técnico suficiente para compreendê-los. ${ }^{269}$

267 Abordaremos as limitações do direito de recesso no item 3.2.3 deste trabalho quando tratarmos dos motivos que levaram a CVM a editar o PO CVM 35.

268 Cf. Processo CVM n. RJ 2007/4933, rel. SEP, j. 19.06.2007.

269 Cf. C. TOMAZELla, Proteção de acionistas e credores... cit., p. 53. Sobre o papel do Conselho Fiscal como órgão de proteção dos acionistas minoritários contra abusos do controlador vide W. BULGARELLI, Apontamento sobre o Conselho Fiscal na reforma da Lei $n^{\circ}$ 6.404/76, in: W. BULGARELli (Coord.), Reforma da Lei das Sociedades por Ações, São Paulo: Pioneira, 1998, p. 181-182. 
No que tange ao envolvimento dos conselheiros fiscais, o inciso III do art. 163 da Lei das S.A. impõe o dever de o Conselho Fiscal, caso instalado, manifestar-se sobre as propostas de incorporação elaboradas pelos órgãos da administração. ${ }^{270}$

A letra da lei é bastante genérica, prevendo a obrigatoriedade de "opinar" sobre a proposta da administração, sem detalhar expressamente o escopo e a amplitude de sua análise ou mesmo o conteúdo dessa opinião.

A princípio, entende-se que a função do Conselho Fiscal é fiscalizar os atos dos administradores e o cumprimento dos seus deveres legais e estatutários sob o aspecto da sua conformidade com a lei e com o estatuto social, sem, no entanto, se imiscuir nos atos de gestão de competência do Conselho de Administração ou da Diretoria. Dessa maneira, a fiscalização do Conselho Fiscal não compreende a apreciação do conteúdo da gestão societária, ou seja, não inclui o julgamento e a manifestação a respeito do mérito e da conveniência das decisões empresariais tomadas pelos administradores, mesmo quando o conselho opina sobre as matérias previstas no inciso III do art. 163 da Lei das S.A., entre elas as operações de incorporação. ${ }^{271}$ Em sentido contrário, M. R. PENTEADO defende que os pareceres do Conselho Fiscal são documentos que expressam não apenas a opinião de seus membros no que diz respeito à legalidade da operação, mas também de sua conveniência e oportunidade. ${ }^{272}$

Como se vê, o escopo da análise a ser desempenhada pelo Conselho Fiscal não é livre de controvérsias. Além disso, traçar a linha tênue que separa a análise da legalidade dos atos dos administradores de uma análise do mérito e da conveniência da decisão não é

270 Lei das S.A.: “Art. 163. Compete ao conselho fiscal: [...]

III - opinar sobre as propostas dos órgãos da administração, a serem submetidas à assembléia-geral, relativas a modificação do capital social, emissão de debêntures ou bônus de subscrição, planos de investimento ou orçamentos de capital, distribuição de dividendos, transformação, incorporação, fusão ou cisão".

271 Cf. A. LAmy Filho; J. L. Bulhões PedreIRA (Coord.), Direito das companhias, v. 1, cit., p. 12741275; M. CARvalhosA, Comentários à Lei de Sociedades Anônimas, v. 3, cit., p. 446; e J. W. LUCENA, que entende que o Conselho Fiscal deve restringir a sua manifestação à parte técnica da operação, sua legalidade e regularidade, sem analisar sua conveniência e oportunidade (Das sociedades anônimas comentários à lei, v. 2, Rio de Janeiro: Renovar, 2009, p. 727).

272 Aumentos de capital das sociedades anônimas... cit., p. 179-180. 
também uma tarefa fácil e cristalina em todos os casos. ${ }^{273}$ Como determinar que os administradores estão cumprindo seu dever de diligência e atuando no interesse da companhia sem entrar no mérito da questão?

Por essas razões, é bastante difícil determinar com precisão o papel que o Conselho Fiscal teria em uma operação de incorporação no que diz respeito à relação de troca de ações. A princípio, a própria decisão sobre a realização da incorporação e a determinação da relação de substituição de ações são questões negociais que estão dentro do escopo de decisão da administração. Nessa linha, portanto, o parecer do Conselho Fiscal dificilmente poderia avaliar a conveniência da realização da operação de incorporação e o atendimento do interesse social, o qual, como veremos adiante, está intimamente ligado com a determinação da relação de substituição de ações a ser proposta aos acionistas.

Além disso, na qualidade de um documento meramente opinativo, o parecer do conselho fiscal não vincula nem cerceia a deliberação a ser tomada pela assembleia geral, a qual detém poderes soberanos para aprovar a operação, ainda que haja parecer desfavorável dos membros do Conselho Fiscal. ${ }^{274}$ Por fim, não se deve esquecer que o funcionamento do Conselho Fiscal é facultativo, o que restringe ainda mais a amplitude do desempenho de suas funções.

Por essas razões, vê-se que a atuação do Conselho Fiscal como órgão que garanta uma relação de troca adequada aos seus acionistas é restrita, não apenas pelo funcionamento facultativo do Conselho Fiscal, mas também pelo questionamento em relação aos seus poderes e a sua competência para eventual questionamento da relação de troca proposta para uma operação.

Passemos agora à análise do papel dos peritos nas operações de incorporação.

273 M. CARVAlHoSA, por exemplo, diz caber ao conselheiro inspecionar os documentos contábeis da companhia para verificar a consonância com o interesse e objetivos sociais (Comentários à Lei de Sociedades Anônimas, v. 3, cit., p. 450).

274 Nem por isso o parecer do conselho fiscal deixa de representar documento essencial ao regular desenvolvimento do procedimento relativo às operações de incorporação, integrando o conjunto de informações que devem ser colocadas à disposição dos acionistas para que possam melhor exercer seus direitos de voto na assembleia geral. Além do parecer disponibilizado aos acionistas, ao menos um membro do conselho fiscal deve comparecer à assembleia geral para responder aos pedidos de esclarecimento formulados pelos acionistas, sendo que sua ausência pode invalidar o conclave a menos que os acionistas, de maneira unânime, dispensem o seu comparecimento. 
Em vista do princípio da realidade do capital social, os bens incorporados ao patrimônio da incorporada serão avaliados por três peritos ou empresa especializada indicados por qualquer acionista ou pela administração da incorporadora, os quais deverão ter acesso à sede da companhia alvo com o propósito de elaborar o laudo de avaliação. Tal laudo deverá ser fundamentado, indicar os critérios de avaliação utilizados e ser instruído com os documentos relativos aos bens avaliados, incluindo uma descrição pormenorizada dos bens, dos direitos, das obrigações e das responsabilidades que compõem o patrimônio da sociedade que será incorporada ou que terá suas ações incorporadas, seguindo os procedimentos de avaliação previstos no art. 8. $^{\circ}$ da Lei das S.A. Assim, as assembleias gerais que aprovarem os laudos terão elementos detalhados de informações com indicação pormenorizada de todos os elementos que foram utilizados na elaboração dos documentos a serem examinados.

No direito brasileiro, portanto, a função dos peritos independentes é avaliar o patrimônio a ser incorporado e determinar se os critérios de avaliação estabelecidos no protocolo são adequados para esse fim. Estando de acordo com os critérios escolhidos, sua função se encerra na conclusão da avaliação da sociedade incorporada ou das ações a serem incorporadas e na declaração de que o valor do patrimônio líquido ou das ações assim apurado é ou não ao menos igual ao montante do capital a realizar da incorporadora, conforme dispõe o art. 226 da Lei das S.A. Em resumo, a função de tais peritos é assegurar a integridade do capital social da incorporadora. ${ }^{275-276}$

Em contrapartida, a Diretiva 2011/35 confere atribuições muito mais amplas e relevantes aos peritos no processo de incorporação, os quais devem se pronunciar expressamente sobre a relação de substituição de ações com o intuito de garantir que ela seja devidamente justificada e que os métodos utilizados para determiná-la são justos e adequados.

275 Cf. N. EIZIRIK, A Lei das S/A comentada... cit., p. 240.

276 Importante lembrar que os avaliadores respondem ainda perante a companhia, acionistas e terceiros por culpa ou dolo na avaliação dos bens, nos termos do art. 8..$^{\circ}$ da Lei das S.A. Sobre esse ponto, E. F. DE PONTES faz crítica à falta de tratamento específico para laudos de avaliação exigidos pela nossa legislação para diferentes fins. Para o autor, o laudo mencionado no art. 8. ${ }^{\circ}$ da Lei das S.A. tem finalidade absolutamente diferente daquele laudo de avaliação elaborado para determinação da relação de substituição de ações e trata-se de um grande equívoco aplicar o regime do laudo do art. 8..$^{\circ}$, principalmente o regime das responsabilidades do $\S 6 .^{\circ}$, para os demais laudos previstos na Lei das S.A. (Incorporação de ações no direito brasileiro... cit., p. 120-126). 
Para isso, já vimos que o art. 10 da Diretiva 2011/35 exige que peritos independentes examinem o projeto de fusão e redijam relatório escrito destinado aos acionistas, declarando se, em sua opinião, a relação de troca é justa e razoável. ${ }^{277}$ Esse relatório, naturalmente, não será preparado de maneira automática e mecânica, já que a determinação da relação de troca é produto da escolha de várias alternativas, de decisões sobre os diferentes métodos e ponderação dos resultados obtidos com tais cálculos. ${ }^{278}$ Para efetuar essa declaração, portanto, os peritos devem, pelo menos: (i) indicar o método ou métodos seguidos para a determinação da relação de troca proposta; (ii) indicar se tais métodos são adequados ao caso concreto para se chegar o mais próximo possível ao valor real das sociedades envolvidas; e (iii) mencionar os valores a que cada um desses métodos conduz, dando parecer sobre a importância relativa concedida a esses métodos na determinação do valor fixado. A redação do artigo tenta cobrir, assim, os fatores essenciais sobre os quais se baseia a relação de troca com a intenção de permitir que os acionistas possam analisar as avaliações feitas mediante explicações sobre os critérios que foram utilizados. Dando conta ainda das possíveis variáveis que são levadas em consideração nos processos de avaliação de empresas e, portanto, da determinação da relação de troca, o art. 10 exige ainda que sejam divulgadas as dificuldades especiais de avaliação.

Como se vê, sob o direito europeu, com o intuito de proteger os acionistas das companhias envolvidas, a solidez da relação de troca deve ser atestada por peritos independentes por meio dos seus relatórios apresentados aos acionistas. Além disso, tais peritos devem ser independentes e experientes e, por isso, exige-se que sejam previamente reconhecidos por uma autoridade judicial ou administrativa. ${ }^{279}$ Para que possam realizar seu trabalho de maneira adequada, cada perito tem o direito de obter das sociedades

277 “Artigo 10. ${ }^{\circ}$ - 1. Relativamente a cada uma das sociedades participantes na fusão, um ou mais peritos independentes destas, designados ou reconhecidos por uma autoridade judicial ou administrativa, examinam o projecto de fusão e redigem um relatório escrito, destinado aos accionistas. Contudo, a legislação de um Estado-Membro pode prever a nomeação de um ou vários peritos independentes para todas as sociedades participantes na fusão, se esta nomeação for feita por uma autoridade judicial ou administrativa, a pedido conjunto das sociedades. Estes peritos podem ser pessoas singulares ou colectivas ou sociedades, consoante a legislação de cada Estado-Membro. 2. No relatório referido no n.. ${ }^{\circ}$ 1, os peritos devem sempre declarar se, em sua opinião, a relação de troca de acções é justa e razoável. Esta declaração deve, pelo menos: a) Indicar o método ou métodos seguidos para a determinação da relação de troca proposta; b) Indicar se tal ou tais métodos são adequados ao caso concreto e mencionar os valores a que cada um desses métodos conduz, dando parecer sobre a importância relativa concedida a esses métodos na determinação do valor fixado. O relatório deve indicar, além disso, as dificuldades especiais de avaliação, caso existam. [...]."

278 Cf. European Communities Commission, Report on the Draft Convention... cit., p. 122.

279 Cf. European Communities Commission, Report on the Draft Convention... cit., p. 49. 
participantes todos os documentos e informações de que careça para elaborar seu relatório, sendo que um relatório diferente deverá ser preparado para cada sociedade. ${ }^{280}$ A existência de dois relatórios distintos justifica-se precisamente porque os acionistas de cada companhia devem se sentir satisfeitos com a relação de troca ao avaliar a documentação preparada separadamente para cada companhia. ${ }^{281}$

Diferentemente do que ocorre no Brasil e na Europa, sob a regulamentação de Delaware, não é exigida a interferência de peritos para avaliar aspecto algum da operação. No entanto, em virtude do posicionamento da jurisprudência, é comum que sejam contratados pareceres de auditores ou de bancos de investimento para embasar a negociação conduzida pelos administradores, uma vez que as cortes de Delaware já decidiram que a negociação de venda de uma companhia sem que os administradores saibam seu valor intrínseco constitui infringência ao dever de diligência. ${ }^{282}$

\subsubsection{Relação de Troca e Liberdade Contratual}

Como vimos nos itens precedentes, não há na lei brasileira exigência legal ou determinação especial quanto aos critérios a serem utilizados para estabelecimento das relações de substituição, os quais poderão ser escolhidos livremente pelos administradores e acionistas das sociedades envolvidas. A Lei das S.A. também não exige, nem no protocolo nem na justificação da operação, que a relação de troca seja determinada mediante elaboração de laudos feitos por peritos independentes ou que a avaliação dos peritos inclua os patrimônios das sociedades incorporadora e incorporada. Ainda, quando a administração ou aqueles que negociam tais operações elaboram laudos para incorporadora

280 Cf. Commission of the European Communities, Proposal to a Third Council directive to co-ordinate the safeguards which Member States require of companies as defined in Article 58, paragraph 2, of the Treaty in order to protect the interests of members and other parties in mergers of joint-stock companies, 16.06.1970, disponível em: <http://aei.pitt.edu/8620/1/8620.pdf>, acesso em: 5 abril 2013, p. 7-8.

281 Cf. European Communities Commission, Report on the Draft Convention... cit., p. 50.

282 Nesse sentido, vide o caso Smith v. Van Gorkom 488 A.2d 858 (Del. 1985), que discute o duty of care para que a administração tenha base para saber se o preço pago em uma operação é ou não justo. Mesmo tendo a decisão do caso dito que a contratação de uma avaliação independente não é essencial para que os administradores cheguem a uma decisão informada, ela acabou dando origem à contratação de fairness opinions pelos administradores para todas as operações como modo de cumprimento dos seus deveres fiduciários (vide R. J. GILSON; B. S. BLACK, The Law and Finance of Corporate Acquisitions, 2. ed., New York: Foundation Press, 1995, p. 1039). Não por outra razão, o caso Van Gorkom é às vezes mencionado como "Investment Bankers' Full Employment Act". Vide também o caso Sealy Mattress Co. v. Sealy, Inc., Del. Ch., 532 A.2d 1324 (1987) no mesmo sentido. 
e incorporada, não há nenhuma exigência de homogeneidade nos critérios de avaliação de tais patrimônios, ficando a cargo da administração eleger aqueles que melhor representarem seus interesses. ${ }^{283}$

Note-se, portanto, que a legislação brasileira endereçou a questão da relação de troca com base no princípio da liberdade contratual das partes, aceitando sua natureza negocial, segundo a qual as companhias são livres para estabelecer as bases das operações societárias e disciplinar os seus termos em todos os seus aspectos segundo juízos de oportunidade e conveniência. $^{284}$

A determinação da relação de substituição das ações pertence, portanto, à ordem de direito privado, inserida na esfera da liberdade contratual das sociedades, razão pela qual a legislação se isentou de prescrever qualquer critério ou parâmetro obrigatório para sua determinação. De acordo com A. LAMY FILHO e J. L. BULHÕES PEDREIRA, as relações de troca "são livremente negociadas e ajustadas pelas duas sociedades. São aspectos do negócio que só interessam às sociedades e seus sócios, porque somente para eles têm implicações patrimoniais. Prevalece, na negociação e estipulação dessas condições, o princípio da liberdade contratual", ${ }^{285-286}$

Da mesma maneira como ocorre no Direito Comparado, entre nós, a preocupação do legislador, assim como da CVM, volta-se muito mais para a proteção dos acionistas minoritários e investidores nas operações entre companhia controladora e

283 Vide N. EIZIRIK, A Lei das S/A comentada... cit., p. 226. Vide também Processo CVM n. RJ 2007/4933, rel. SEP, j. 19.06.2007.

284 Cf. A. LAMY FILHO; J. L. BUlHÕes PEDREIRA, A Lei das S.A. (pressupostos, elaboração, aplicação)... cit., p. 667. Vide também PAS CVM n. 10/00, rel. Dir. Luiz Antonio de Sampaio Campos, j. 08.07.2004.

285 A. LAMY FILHO; J. L. BULHÕES PEDREIRA, A Lei das S.A. (pressupostos, elaboração, aplicação)... cit., p. 667. Vide também L. L. CANTIDIANO, Análise crítica do Parecer de Orientação CVM 34, Revista de Direito Bancário e do Mercado de Capitais, n. 41, São Paulo: RT, 2008, p. 136. Com a devida vênia, ousamos discordar dessa afirmação no que diz respeito à relação de troca não ter nenhum efeito sobre terceiros, como veremos a seguir ainda neste item.

286 Quanto ao argumento de que a relação de troca não tem implicações apenas patrimoniais, mas também políticas, deve-se, na verdade, levar em conta que mesmo os direitos políticos dentro das sociedades anônimas são disponíveis e têm caráter econômico. O poder de controle é uma modalidade de poder econômico e o voto dentro das companhias defende interesses puramente patrimoniais, sendo, por isso mesmo, disponível. Diferentemente ocorre com o voto político, pois este é exercício de cidadania e instrumento para influir nas decisões que afetam a pessoa em si mesmo e, por conta disso, indisponível (cf. G. D. C. PEREIRA, Alienação do poder de controle acionário, São Paulo: Saraiva, 1995, p. 4). 
controlada ou entre sociedades sob controle comum - as chamadas "partes relacionadas" do que para a regulação das operações entre partes independentes. ${ }^{287}$

Entre partes relacionadas, uma vez que o controlador decide a conveniência e os termos da incorporação em todas as sociedades envolvidas, são necessárias medidas especiais de proteção aos acionistas minoritários, ${ }^{288}$ as quais serão objeto de análise específica no item 3.2 adiante.

Por outro lado, tratando-se de companhias com controladores diversos, as operações de incorporação se resolvem como resultado de negociações em que os vários aspectos em jogo são livremente ponderados, após as devidas e necessárias avaliações patrimoniais, afinal aprovadas pelas maiorias distintas dos sócios que vão compartilhar o patrimônio comum decorrente da incorporação. ${ }^{289}$

Nesse mesmo sentido, a CVM já decidiu que

na operação isolada de incorporação de ações as sociedades envolvidas são livres para estabelecer a relação de troca que melhor lhes aprouver. Quando as sociedades envolvidas na operação encontram-se sobre controle acionário diverso, ou bem as partes chegam a um acordo quanto à relação de troca que deve prevalecer, ou o negócio pretendido por ambas não chega a ser consumado. ${ }^{290}$

Essa estratégia de regulação aplicável às operações de incorporação entre partes independentes foi escolhida pela Lei das S.A. assentada no pressuposto de que os administradores e acionistas controladores de cada uma das sociedades buscarão negociar os termos da operação da maneira mais conveniente para os seus interesses e dos acionistas minoritários - os quais deveriam ser idênticos nesses casos -, i.e., buscar a relação de troca mais interessante possível. Para isso, pressupõe-se que buscarão a melhor avaliação dos seus respectivos patrimônios sociais, discutirão intensamente sobre os métodos mais

287 Cf. N. EIZIRIK, A Lei das S/A comentada... cit., p. 212.

288 Idem, ibidem, p. 250.

289 A. LAMY FILHO; J. L. BUlHÕES PEDREIRA, A Lei das S.A. (pressupostos, elaboração, aplicação)... cit., p. 679 .

290 Vide voto vencedor do então presidente da CVM Luiz Leonardo Cantidiano no Processo CVM n. RJ 2003/12770, rel. SEP, j. 26.12.2003. 
adequados de avaliação das demais sociedades envolvidas e terão, como consequência, a valorização das suas respectivas ações e da relação de troca de suas ações. Dessa maneira, a determinação da relação de troca se dará como decorrência natural do processo de negociação, o que não ocorreria nas operações entre "partes relacionadas". 291

Assim, ao defender seus próprios interesses como acionista na busca do maior valor e das condições mais vantajosas, cada controlador, ao menos em tese, automaticamente também protegeria o interesse dos minoritários. ${ }^{292}$ Esse pressuposto alinha-se, inclusive, com a própria natureza jurídica da incorporação sob seu aspecto contratual. Como se viu acima, a natureza contratual do instituto pressupõe um conflito de interesses que se resolve para formar o contrato base que regulará as incorporações, sendo que, de um lado, uma das sociedades buscará se compenetrar na outra transmitindo seu patrimônio e sócios pelo maior valor possível, enquanto a outra visará à ampliação do seu patrimônio diminuindo o mínimo possível sua parcela de participação no patrimônio unificado das companhias. É, portanto, na negociação da relação de troca que os aspectos contratuais da incorporação e o conflito de interesses entre as duas sociedades, ambos da natureza dessas operações, encontram-se no seu ápice.

Na prática, portanto, tratando-se de companhias com controladores diversos, a operação de incorporação nada mais é do que o resultado de um longo processo de negociação em que os vários aspectos em jogo são ponderados e afinal aprovados pelas maiorias distintas dos sócios que irão, a partir daquele momento, partilhar o patrimônio comum que decorre da incorporação.

Embora a mesma abordagem tenha sido seguida na União Europeia de acordo com as diretrizes impostas pela Diretiva 2011/35, segundo a qual a determinação da relação de troca das ações também fica a cargo da negociação entre os administradores, vimos que as legislações europeias preocupam-se especificamente com a questão da relação de substituição de ações de maneira muita mais acertiva do que aquela verificada

291 Cf. N. EIZIRIK, A Lei das S/A comentada... cit., p. 226-227.

292 Vide R. V. RIBEIRO, Incorporação de companhia controlada, in: W. J. WARDE JR. (Org.), Fusão, cisão, incorporação e temas correlatos, São Paulo: Quartier Latin, 2009, p. 111. Vide também ata de reunião extraordinária do Colegiado da CVM no Processo CVM n. RJ 2000/6117, j. 23.02.2001 que afirma: "Quando não existe tal relação [de controle] é evidente que a negociação da incorporação pressupõe a defesa dos interessados da incorporada por seus controladores e administradores". 
na legislação nacional quando regulam os relatórios exigidos pela administração, pelos peritos e nas regras de avaliação das companhias envolvidas. Muito do que existe no direito estrangeiro, entendemos, deveria ser aproveitado no Brasil.

Além disso, a apreciação e a aprovação da relação de troca pela assembleia geral de acionistas parecem justificar ainda mais a liberdade contratual e a margem de negociação conferida aos administradores ou àqueles que negociam os termos de tais operações. Como órgão máximo da companhia e hierarquicamente superior aos demais, a assembleia geral tem competência para decidir todos os negócios relativos ao objeto da companhia e tomar as resoluções que julgar convenientes em benefício do interesse social (conforme art. 121 da Lei das S.A.). ${ }^{293}$ Dessa maneira, uma vez definida a relação de substituição e apresentada no protocolo aos acionistas das sociedades envolvidas, cabe a eles unicamente analisá-la e fazer um juízo sobre a sua conveniência, aprovando a operação se entenderem que a relação de substituição é apropriada, ou rejeitando-a, se discordarem dos termos propostos, podendo ainda se retirar da companhia incorporada recebendo o valor de reembolso. ${ }^{294}$

Nesse sentido, A. LAMY FILHO e J. L. BULHÕES PEDREIRA lecionam que

[a] vontade de cada sociedade é expressa pela maioria dos seus acionistas, reunidos em Assembléia Geral Extraordinária, que ao aprovarem o protocolo de incorporação [...] fazem um juízo coletivo sobre (a) a contribuição de cada sociedade para o capital próprio e a rentabilidade da incorporadora após a incorporação [...], e (b) a distribuição, entre os conjuntos de sócios de cada uma, dos benefícios econômicos que fundamentam a operação, tais como economias de escala, aumento de eficiência e melhoria da posição de mercado. ${ }^{295}$

Entretanto, ainda que a assembleia geral convalide uma relação de substituição prejudicial, entendemos ser possível o questionamento da validade da operação, pois a relação de troca, sendo um processo que envolve a troca de valores mobiliários a cargo da administração e em nome de todos os seus acionistas, não pode ser considerada como um direito patrimonial disponível tal como ocorre nas contraprestações de outros contratos que

\footnotetext{
293 Cf. N. EIZIRIK, A Lei das S/A comentada... cit., p. 232.

294 Nesse sentido, vide PAS CVM n. 24/04, rel. Dir. Eli Loria, j. 31.07.2007.

295 Direito das companhias, v. 2, cit., p. 1762.
} 
tenham a natureza de permuta, sobretudo nas companhias abertas. Em primeiro lugar, pela própria peculiaridade do processo de negociação que é, geralmente, conduzido pela administração no interesse de todos os acionistas e sujeito, portanto, a toda gama dos deveres fiduciários de administração que impedem uma atribuição de valor aleatório para as ações. Em segundo lugar, porque não apenas os direitos dos acionistas são afetados, mas também o próprio mercado via, por exemplo, contratos derivativos que tenham a ação em questão como índice ou parâmetro de valor e em relação aos quais nem a administração nem os acionistas detêm controle algum. A aprovação de uma relação de troca ruim, fazendo com que o preço de uma ação caia, pode, portanto, afetar terceiros alheios ao âmbito privado da negociação. ${ }^{296}$

Cabe aqui, no entanto, uma ressalva fundamental: embora a nossa legislação societária tenha, a princípio, inserido a determinação da relação de substituição com base na liberdade contratual, essa liberdade não é irrestrita e desprovida de qualquer outro parâmetro ou sujeita ao livre-arbítrio das partes. Como vimos, a relação de substituição de ações não corresponde a um "preço" puro que pode ser determinado discricionariamente entre as partes envolvidas. Além de todas as informações que devem ser divulgadas aos acionistas relativas aos critérios utilizados para a sua determinação e da necessidade de se seguir um procedimento específico previsto em lei, a nossa Lei das S.A. também estabelece outros parâmetros que acabam por restringir a liberdade de determinação da relação de substituição de ações, exigindo sua devida justificação aos acionistas. Vistas até aqui as principais regras previstas para regular os negócios de incorporação, exploraremos os demais limites impostos pela nossa lei para a determinação da relação de troca nos itens a seguir.

\subsection{Limites à Determinação da Relação de Substituição de Ações}

Em apertada síntese, vimos que nas operações de incorporação (i) prevalece o princípio da liberdade contratual na determinação da relação de substituição das ações, sendo as companhias livres para estabelecer as bases das operações de incorporação e escolher os critérios que serão utilizados para a determinação das relações de substituição;

296 Nesse mesmo sentido, vide E. F. DE PONTES, Incorporação de ações no direito brasileiro... cit., p. 4243. 
(ii) a avaliação dos patrimônios das companhias envolvidas, por sua vez, preocupa-se muito mais em assegurar a integridade do capital social da incorporadora do que em oferecer parâmetros que auxiliem a definição da relação de substituição; e (iii) o papel dos peritos e conselheiros fiscais na análise e determinação da relação de substituição é bastante reduzido, principalmente quando comparado com o papel que os peritos têm nas legislações estrangeiras. Vê-se, dessa maneira, que a Lei das S.A. deixou as sociedades bastante livres para convencionarem tanto a relação de substituição das ações como o valor a ser atribuído ao patrimônio líquido da sociedade a ser incorporada.

Diante da ampla liberdade conferida pela lei societária brasileira às partes que negociam uma operação de incorporação e em vista da possibilidade de haver comportamentos oportunistas por parte dos administradores e acionistas controladores, a ideia dos itens seguintes é explorar outros limites impostos pela Lei das S.A. para a determinação da relação de substituição das ações.

Evidentemente que a imposição da operação sobre os demais acionistas só é válida se forem obedecidos os requisitos e as balizas impostas pela lei, de modo que a proteção dos acionistas minoritários em operações de incorporação decorre, na verdade, de um conjunto de exigências simultâneas, dada a inutilidade de mecanismos únicos de proteção, como a mera exigência de cumprimento do interesse social ou a utilização dos balanços para determinação do valor das sociedades envolvidas. ${ }^{297}$

LAMY FILHO e BULHÕES PEDREIRA lecionam que, como em qualquer negócio típico, prevalece nas incorporações a liberdade de contratar, limitada por normas cogentes ou dispositivas. ${ }^{298}$ Para a contratação da relação de substituição de ações os limites são apenas os indispensáveis à proteção dos interesses dos sócios minoritários e à preservação da realidade do capital social. ${ }^{299-300}$ N. EIZIRIK, por sua vez, complementa dizendo que a

297 Nesse sentido, vide W. BULgaRelli, A incorporação das sociedades anônimas, São Paulo: Universitária de Direito, 1975, p. 217.

298 A. LAMY FILHO; J. L. BULHÕES PEDREIRA (Coord.), Direito das companhias, v. 2, cit., p. 1748.

299 A Lei das S.A. cit., p. 668.

300 No mesmo sentido, N. EIZIRIK destaca como normas cogentes que se aplicam a todas as operações de incorporação aquelas que visam a, sobretudo, definir o objeto e os principais requisitos dessas operações, bem como proteger os interesses dos acionistas e de terceiros. Segundo o autor, são exemplos de tais regras aquelas que regulam a definição da condição do negócio no protocolo e na justificação 
liberdade de contratar aplicável às relações de substituição é limitada pelo dever que a Lei das S.A. impõe aos acionistas controladores das sociedades envolvidas de exercerem seu poder de controle no interesse social e abstendo-se de promover operações com vistas à obtenção de vantagens indevidas, conforme consta no art. $117, \S 1 .^{\circ}$, da Lei das S.A..$^{301}$

Também nesse sentido já se manifestou a CVM, dizendo que a Lei das S.A. estabeleceu para as matérias previstas no protocolo o princípio da ampla liberdade de contratar, ressalvadas apenas as disposições relativas ao interesse social das sociedades envolvidas, e a proteção de credores e acionistas minoritários, conforme se vê inclusive da necessidade da justificação prevista no art. 225 da Lei das S.A. ${ }^{302}$

Os itens a seguir explorarão, justamente, esses limites. Os preceitos neles estudados, principalmente as questões relativas à necessidade de atendimento do interesse social, ao abuso de poder de controle, aos deveres fiduciários dos administradores e ao tratamento equitativo dos acionistas servirão também de base para a discussão de casos especiais de determinação de relação de substituição nos capítulos seguintes.

\subsubsection{Preservação da Realidade do Capital Social}

A questão da preservação da realidade do capital social foi explorada no item 2.2.2 acima quando tratamos da avaliação do patrimônio líquido da incorporada em vista da exigência imposta pelo art. 226 da Lei das S.A., valendo essa regra também para a avaliação de eventuais ações sendo incorporadas.

Como vimos, as operações de incorporação implicam, em geral, aumento de capital social e emissão de ações de acordo com a relação de troca determinada (salvo no caso de utilização de ações em tesouraria). Por força do que dispõe o art. 226 da Lei das S.A., a operação somente pode ser concluída nas condições ajustadas no protocolo se os peritos entenderem que o valor do patrimônio líquido da incorporada ou das ações que serão incorporadas é, ao menos, igual ao montante do capital social a ser formado. O que

apresentada às assembleias gerais e disciplinam a avaliação dos patrimônios líquidos que formarão o capital social (A Lei das S/A comentada... cit., p. 213).

301 A Lei das S/A comentada... cit., p. 227.

302 PAS CVM n. 10/00, rel. Dir. Luiz Antonio de Sampaio Campos, j. 08.07.2004. 
nos interessa discutir neste item, entretanto, é até que ponto as regras de avaliação e o princípio da realidade do capital social podem ser vistos como limites impostos à determinação da relação de troca contratada e uma forma de proteção aos acionistas, principalmente aos acionistas da incorporadora. ${ }^{303}$

Já demonstramos neste trabalho que, embora seja obrigatória e indispensável a avaliação do patrimônio líquido ou das ações incorporadas que formarão o capital social da incorporadora, essa exigência do art. 226 da Lei das S.A. se justifica para proteção dos credores com o intuito de assegurar a integridade do capital social. O propósito dessa regra, portanto, não foi estabelecer parâmetros para determinação da relação de substituição, e sim garantir efetividade ao princípio da realidade do capital social tal como ocorre na formação de capital em bens, impedindo que o patrimônio líquido incorporado ou as ações incorporadas sejam integrados ao capital social da incorporadora por valor superior ao real.

Em outras palavras, o valor do aumento do capital social da incorporadora e o valor pelo qual o patrimônio líquido da incorporada ou as ações sendo incorporadas serão vertidos para formação desse capital, ambos diretamente dependentes da avaliação realizada pelos peritos exigidos por lei, não têm influência direta na definição da relação de substituição. ${ }^{304}$ A relação de troca, especificando o número, a espécie e a classe das ações que serão emitidas pela sociedade incorporadora, decorre, direta e exclusivamente, da negociação entre as sociedades envolvidas, independentemente dos resultados decorrentes da avaliação do patrimônio da incorporada, do valor das ações a serem incorporadas ou, ainda, do valor do aumento do capital a ser realizado na sociedade incorporadora.

Por essa razão, a regra de avaliação e o princípio da realidade do capital social funcionam muito mais como um limitador à realização da própria operação do que como uma baliza para determinação da relação de substituição das ações propriamente dita. Isto é, essas regras podem impedir que a operação seja sequer concluída caso fique

303 Vide C. TOMAZELLA ao dizer que "[enquanto] os acionistas da sociedade incorporadora parecem ser protegidos pelas regras de avaliação do patrimônio da incorporada, os acionistas da incorporada o são pelos parâmetros impostos para a fixação da relação de substituição de ações" (Proteção de acionistas... cit., p. 64).

304 Cf. A. LAmy Filho e J. L. BUlhões PedReira lecionam que o que determina os direitos de participação das ações no capital social da incorporadora é o número, espécie e classe das ações que substituirão as ações extintas, e não o valor do aumento de capital nem o valor pelo qual os patrimônios são vertidos para a formação do capital (Direito das companhias, v. 2, cit., p. 1763). 
demonstrado que os bens incorporados não correspondem ao valor do aumento de capital, mas não funcionam precisamente como um parâmetro definidor da relação de troca de ações. $^{305}$

Dessa maneira, mesmo que a lei exija que os peritos confirmem o valor do patrimônio da incorporada ou das ações incorporadas, não há aí nenhuma proteção aos acionistas da incorporadora no sentido de lhes assegurar uma relação de troca satisfatória, pois poderão ser emitidas tantas ações aos acionistas ingressantes quanto aquelas que forem determinadas pela relação de substituição negociada. Exemplificativamente, é possível se pensar em um aumento de capital na incorporadora no valor de R \$100,00, com emissão de 100 novas ações, ou o mesmo aumento de $\mathrm{R} \$ 100,00$, porém com emissão de 200 novas ações, a depender do que tiver sido negociado na relação de troca com a sociedade incorporada ou que tenha suas ações incorporadas. Em ambos os casos, o papel dos peritos estaria cumprido nos termos do art. 226 da Lei das S.A. se comprovassem que os bens sendo incorporados valem $\mathrm{R} \$ 100,00$, independentemente do número de ações sendo emitidas na sociedade incorporadora, bem como estaria plenamente atendido o princípio da realidade do capital social.

Essa desvinculação entre a relação de substituição de ações e o aumento de capital é possível porque, a nosso entender, nas operações de incorporação, as novas ações emitidas em favor dos acionistas ingressantes não precisam ter seu preço de emissão fixado com base nos critérios estabelecidos no $\S 1 .^{\circ}$ do art. 170 da Lei das S.A., ${ }^{306}$ e sim obtido pela divisão (i) do valor apurado para o patrimônio líquido incorporado ou para as ações sendo incorporadas, determinado pelos peritos de acordo com os critérios indicados no

305 Corroborando também a desvinculação entre as regras de avaliação e formação de capital e a relação de troca das ações, vide L. A. BIANCHI quando diz que "l'aver riconosciuto fondamento alla preoccupazione in merito alla effettività del capitale post fusione non implica anche, a nostro avviso, che la stima del concambio debba ritenersi rigidamente vincolata ai valori contabili e non possa viceversa assumere valori diversi" (Il Giudizio di "Congruità" del Rapporto di Cambio nella Fusione, Universitá degli Studi di Trento, 1993, p. 116).

306 De acordo com a exposição justificativa do anteprojeto convertido na Lei das S.A., as regras referentes a preço de emissão de novas ações visam a impedir a diluição injustificada dos minoritários que não exerceram seu direito de preferência em um aumento de capital, exigindo que as novas ações emitidas nesses casos tenham preço de emissão justificado e compatível com o valor econômico da ação da companhia. Dessa maneira, os acionistas que não subscreveram o aumento de capital serão diluídos, mas terão a garantia de que aqueles que aumentaram suas participações na companhia pagaram valor correspondente e justificável para incrementar sua participação no capital social. 
protocolo, pelo (ii) número de ações a serem emitidas, de acordo com a relação de troca negociada. $^{307}$

Parece bastante evidente que, se o número de ações a serem criadas em função da relação de troca já é previamente conhecido em função do protocolo firmado, e também já é determinado o valor do aumento do capital social que deverá ser realizado para fazer frente ao patrimônio vertido para a incorporadora, o preço de emissão das novas ações só pode ser uma decorrência desses dois fatores, obtido por uma conta matemática de divisão entre esses montantes, mas não em função dos critérios do $§ 1 .^{\circ}$ do art. 170 da Lei das S.A. Tais critérios se aplicam, justamente, quando o número de ações que deverão ser emitidas em um aumento de capital é ainda desconhecido, o qual será então determinado pelo preço de emissão com o objetivo de evitar a diluição injustificada dos acionistas que não exercerem a preferência.

Não obstante, diversos autores já se manifestaram no sentido de que as regras que regulam o preço de emissão de novas ações em aumento de capital se aplicam às novas ações emitidas em decorrência da implementação de uma operação de incorporação. Nesse sentido, A. XAVIER defende expressamente que o aumento de capital da sociedade incorporadora com as ações a serem incorporadas deve obedecer às regras gerais que regulam o preço de emissão das ações. ${ }^{308}$ No mesmo sentido, WALFRIDO J. WARDE JR. ressalta que o Parecer de Orientação CVM n. 1, de 27 de setembro de 1978, o qual trata sobre a inteligência do art. $170, \S 1 .^{\circ}$, da Lei das S.A., exerce importante papel para limitar a diluição dos minoritários da incorporadora nos casos de incorporações reversas. ${ }^{309}$

Se as regras de preço de emissão fossem aplicáveis às operações de incorporação, poderíamos, de fato, afirmar que haveria alguma proteção aos acionistas da

307 Cf. A. LAMY FILHO; J. L. BUlHÕES PEDREIRA (Coord.), Direito das companhias, v. 2, cit., p. 1783. No caso das ações com valor nominal, a vedação prevista no art. 13 da Lei das S.A. de que tais ações não possam ser emitidas por valor inferior ao valor nominal, poderia representar um limite à livre emissão de tantas ações quanto for determinado pela relação de troca já que já existe um preço de emissão mínimo determinado pela lei. No entanto, o desuso de tais ações com valor nominal torna a questão menos relevante na nossa análise.

308 A. XAVIER, Incorporação de ações: natureza jurídica e regime tributário... cit., p. 136.

309 Os poderes manifestos no âmbito da empresa societária e o caso das incorporações: a necessária superação do debate pragmático-abstracionista, in: R. R. M. DE CASTRO; L. A. N. DE MOURA AZEVEDO (Coord.), Poder de controle e outros temas de direito societário e mercado de capitais, São Paulo: Quartier Latin, 2010, p. 67. 
sociedade incorporadora no que tange à relação de troca em si, pois o número de ações da incorporadora a ser emitido estaria limitado ao valor do capital social a ser aumentado, dividido pelo preço de emissão das novas ações. No entanto, entendemos não ser esse o caso.

Em primeiro lugar, porque esse pensamento atenta contra a própria lógica da operação, na qual a relação de troca é negociada previamente entre as companhias de acordo com critérios próprios, independentes dos critérios de preço de emissão para novas ações da incorporadora. $\mathrm{O}$ que as partes definem no protocolo é a relação de troca das ações, as regras para avaliação do patrimônio líquido ou das ações sendo incorporadas e o valor do aumento de capital da incorporadora, conforme previsto no art. 224 da Lei das S.A. Definidos tais pontos, o preço de emissão das ações da companhia incorporadora será naturalmente obtido como consequência de tais valores. Nesse sentido, A. LAMY FILHO e J. L. BULHÕES PEDREIRA também defendem que

[a]s sociedades, partes do negócio, têm liberdade de contratar a relação de substituição de ações, o preço de emissão das ações a serem criadas e a parcela desse preço destinada à formação do capital social, mas essa liberdade tem por limite a norma do art. 226 da LSA, segundo a qual a operação somente poderá ser efetivada nas condições constantes do protocolo ou da justificação se os peritos nomeados determinarem que o valor do patrimônio líquido a ser vertido para a formação do capital social é, ao menos, igual ao montante do capital a realizar" (grifos nossos). ${ }^{310}$

Em segundo lugar, não há em nenhuma passagem da Lei das S.A. exigência para que os critérios do art. 170, § 1. ${ }^{\circ}$, sejam seguidos para a emissão de ações decorrentes de operações de incorporação. Pelo contrário, vimos que a Lei das S.A. deixou as sociedades livres para negociar e ajustar a melhor relação de troca que entendam cabível. O que existe na lei são regras de preço de emissão para aumentos de capital, o que, como discutimos aqui, tem natureza absolutamente distinta das operações de incorporação. ${ }^{311} \mathrm{O}$ aumento de capital é consequência da incorporação, cuja deliberação necessariamente

310 Direito das companhias, v. 2, cit., p. 1774.

311 G. FERRI não menciona expressamente a questão do preço de emissão, mas, ao discutir os aumentos de capital em operações de fusão, afirma categoricamente que nesses casos não se colocam os problemas que se enfrentam quando o aumento de capital é o unico fim desejado (Le Società... cit., p. 691). 
preordenou, ${ }^{312}$ mas não corresponde às operações de incorporação e pode, em muitos casos, ser até mesmo dispensável quando houver atribuição de ações em tesouraria ou quando a própria operação não implicar por si só um aumento de capital. ${ }^{313}$ Além disso, nas operações de incorporação não há, justamente, direito de preferência a ser exercido pelos acionistas da sociedade incorporadora que, caso fosse renunciado, necessitaria da proteção adicional do preço de emissão que foi, justamente, a razão da norma prevista no $\S$ $1^{\circ}$ do art. 170 da Lei das S.A. ${ }^{314}$

Há ainda mais argumentos. Os critérios de preço de emissão foram estabelecidos para evitar a diluição injustificada dos acionistas ao determinar o valor econômico da ação que será emitida por uma única companhia, individualmente considerada. Se tais critérios fossem utilizados para a emissão de novas ações decorrentes da incorporação, certamente não deveríamos ter como base apenas o patrimônio e os negócios da incorporadora, e sim o patrimônio e/ou prognóstico de resultados da companhia que resultasse da conclusão da operação de incorporação, o que claramente demonstra que o aumento de capital na incorporadora não pode ser tratado como um aumento de capital comum, com as regras de preço de emissão que levassem em conta apenas os aspectos da incorporadora como se não existisse uma operação de incorporação.

Além disso, caso estivéssemos discutindo uma operação de fusão - instituto do qual, frise-se, entendemos que a incorporação é espécie -, a questão das regras de preço de emissão para aumento de capital jamais seria levada em consideração pelo simples fato de que, em tais operações, não há aumento de capital, e sim formação de nova sociedade cujo patrimônio será distribuído entre os sócios de acordo com a relação de troca negociada, essa, sim, inalterada independentemente de estarmos tratando de uma operação de incorporação ou de fusão, o que demonstra a unicidade do instituto e sua independência do aumento de capital.

312 F. C. PONTES DE MIRANDA, Tratado de direito privado, t. LI cit., p. 74.

313 Também no direito português R. VENTURA já se pronunciou dizendo que "o simples fato de também neste caso haver uma aquisição patrimonial não é bastante para justificar a aplicação, de princípio, do regime do aumento de capital por entradas autônomas" e que "não há analogia alguma entre o regime das entradas, em dinheiro ou espécie, e a transmissão do patrimônio da sociedade incorporada" (Fusão, cisão, transformação... cit., p. 68 e 70). M. CARVALHOSA e N. EIZIRIK, por sua vez, defendem que as disposições do art. 252 da Lei das S.A. regulam inteiramente a matéria de incorporação de ações e não aquelas do art. 170 do mesmo diploma legal dado que elas não se confundem com a subscrição de capital em bens (Estudos de direito empresarial... cit., p. 87).

314 Vide também nesse sentido R. VENTURA, Fusão, cisão, transformação... cit., p. 71. 
Por fim, sabemos que a legislação societária não exigiu a avaliação da companhia incorporadora como requisito para permitir a concretização das incorporações e seria desarrazoado, portanto, inferir que o preço de emissão das novas ações emitidas pela incorporadora tivesse que se basear em alguns dos critérios do $\S 1 .^{\circ}$ do art. 170 da Lei das S.A. É verdade que a Lei das S.A. também não exige laudos de avaliação para a definição do preço de emissão de novas ações, mas, na prática, sabemos que tais laudos ou, pelo menos, uma avaliação conduzida pela administração são necessários para que se possa definir o preço de emissão das novas ações em aumentos de capital, já que cabe à administração justificar pormenorizadamente os critérios econômicos que levaram à definição do preço de emissão nos termos do $§ 7 .^{\circ}$ do art. 170 da Lei das S.A. ${ }^{315}$

Conforme nosso entendimento manifestado acima, também já decidiu a CVM ao dizer que os critérios e parâmetros contidos no art. 170 da Lei das S.A. para definição do preço de emissão de novas ações não se impõem na hipótese de incorporação, prevalecendo a liberdade das partes de ajustarem a relação de substituição conforme juízo de conveniência e oportunidade. ${ }^{316}$

É inegável, no entanto, que existe profunda correlação entre a relação de troca e a avaliação dos patrimônios das sociedades envolvidas nas operações de incorporação. É possível, portanto, que na conclusão da operação se chegue a um número de ações a serem emitidas pela incorporadora e um preço de emissão próximo ao que seria obtido se um dos critérios do preço de emissão previsto no $\S 1 .^{\circ}$ do art. 170 tivesse sido utilizado, notadamente se considerarmos que em ambas as hipóteses a incorporadora pode utilizar o mesmo método de avaliação para apurar seu valor econômico. Isso não quer dizer, no entanto, que as regras de preço de emissão de ações em aumentos de capital tenham que ser seguidas ou que os critérios de avaliação da incorporadora para determinação da

315 Nesse ponto, vide, inclusive, a opinião de M. CARVALHOSA, que chega a dizer ser obrigatória a elaboração de laudo técnico externo e independente como condição de validade para emissão de ações com base na perspectiva de rentabilidade futura (Comentários à Lei de Sociedades Anônimas, v. 3, cit., p. 531).

316 Cf. PAS CVM n. 10/00, rel. Dir. Luiz Antonio de Sampaio Campos, j. 08.07.2004, ao dizer que: "o primeiro [equívoco] diz respeito a eventual vinculação à relação de substituição (ou relação de troca) aos critérios do art. 170 da Lei n. 6.404/76 que trata do preço de emissão das ações para efeito de aumento de capital, pós-subscrição de novas ações. [...] Este critério e os parâmetros ali contidos não se impõem na hipótese de incorporação. Nessas operações, como já visto, prevalece a liberdade das partes de ajustarem a relação de substituição, conforme juízo de conveniência e oportunidade". 
relação de substituição tenham que estar adstritos àqueles previstos no $\S 1 .^{\circ}$ do art. 170 ou, ainda, que outros fatores não possam entrar em jogo na formação da relação de troca, independentemente da avaliação da incorporadora.

Em vista do que expusemos acima, entendemos que a regra do art. 226 da Lei das S.A. e o princípio da realidade do capital social justificam-se plenamente para proteção dos interesses de terceiros credores, mas pouco ou nada auxiliam na proteção dos interesses dos acionistas das companhias envolvidas em não serem diluídos diante de uma relação de troca ruim.

\subsubsection{Proteção dos Interesses dos Minoritários}

Dando continuidade aos limites para determinação da relação de substituição de ações, passaremos à análise de outras normas que atuam em função dos interesses dos minoritários para analisar como elas podem influenciar a determinação da relação de troca das ações, notadamente a necessidade de atendimento do interesse social.

\subsubsection{Justificação e Interesse Social}

O poder dado à maioria acionária de aprovar as operações de incorporação e redefinir os direitos de todos os sócios não é, evidentemente, absoluto, mas está subordinado à necessária comprovação do caráter justificado dessa decisão, uma vez que ela implica a diluição da participação dos demais sócios e altera significativamente os direitos dos acionistas. ${ }^{317}$

Essa necessidade de justificação ex ante da operação não é apenas a contrapartida lógica do poder conferido à maioria para modificar o direito de todos os sócios, mas serve também, juntamente com as demais informações que devem ser colocadas à disposição dos acionistas, como importante instrumento de controle social

317 Cf. A. PÉRez Troya, La determinación del tipo de canje... cit., p. 40 e 48. E. F. DE PONTES em seu trabalho fala que um dos axiomas das operações de incorporação é que ela seja promovida mediante uma motivação juridicamente justificada (Incorporação de ações no direito brasileiro... cit., p. 32). 
sobre a decisão que poderá ser posteriormente utilizado pelos minoritários para avaliarem a operação proposta e proporem eventuais contestações aos seus termos.

Para atender a esse fim, a Lei das S.A. exige que o protocolo seja submetido às assembleias gerais das sociedades interessadas acompanhado da justificação, prevista no art. 225 da Lei das S.A. ${ }^{318}$

Enquanto o protocolo tem natureza eminentemente técnica e de negócio jurídico, a justificação, também elaborada pelos representantes das sociedades, constitui uma espécie de "exposição de motivos" da operação cuja função é fornecer às assembleias gerais informações que auxiliarão os acionistas a avaliarem as estipulações do protocolo e os termos da operação proposta. É na justificação também que os acionistas preferencialistas avaliarão a argumentação e a justificativa para eventuais modificações dos direitos de suas ações preferenciais, caso tais alterações sejam propostas no escopo da operação. $^{319}$

Embora seja na justificação que se encontram os fundamentos que embasam a celebração de uma operação de incorporação, esse documento é tratado com bastante descaso pela doutrina e pela prática societária. Por facilidade e economia, a justificação é geralmente redigida de maneira burocrática, meramente para atender a uma exigência legal, e vem consolidada integralmente no protocolo de incorporação em vez de ser apresentada como documento em separado para cada sociedade. ${ }^{320}$ Nesse ponto, a Lei das S.A. também é criticável, pois coloca como condição da conclusão das operações de incorporação a aprovação apenas do protocolo, nada falando sobre a aprovação da justificação (conforme art. 227, $\S 1^{\circ} .^{\text {) }}$ ou em que momento tal documento deve ser submetido para aprovação das assembleias gerais das companhias envolvidas, reforçando o demérito que a prática negocial vem conferindo ao documento. ${ }^{321}$

318 Cf. N. EIZIRIK, A Lei das S/A comentada... cit., p. 233.

319 Cf. A. LAMY FILHO; J. L. BUlHÕES PEDREIRA (Coord.), Direito das companhias, v. 2, cit., p. 1760.

320 Nessa mesma linha, R. VENTURA afirma que cada sociedade deveria receber seu próprio documento de justificação que desse as razões específicas para aquela sociedade, já que tais justificativas deveriam ser necessariamente diversas para cada uma delas (Fusão, cisão, transformação... cit., p. 78).

321 Vide nesse sentido comentários de E. F. DE PONTES, Incorporação de ações no direito brasileiro... cit., p. 35-37. O autor defende que a justificação deveria ser pressuposto jurídico-axiomático da operação de incorporação, de modo que devesse ser tratada como condição para a realização da operação e 
Entre as informações que devem constar na justificação, exige o art. 225 da Lei das S.A. que constem (i) os motivos ou fins da operação, e o interesse da companhia na sua realização; (ii) as ações que os acionistas preferenciais receberão e as razões para a modificação dos seus direitos, se prevista; (iii) a composição, após a operação, segundo espécies e classes das ações, do capital das companhias que deverão emitir ações em substituição às que se deverão extinguir; e (iv) o valor de reembolso das ações a que terão direito os acionistas dissidentes. Entre elas, certamente a principal função da justificação é dar informações aos acionistas sobre os motivos ou fins da operação a fim de demonstrar que ela atende aos interesses da companhia, ${ }^{322}$ de modo que fique claro o motivo que levou a companhia a propor a operação à assembleia geral e a proteção de um interesse legítimo da companhia. Os fins ou motivos da operação podem ser diversos, de ordem econômica ou estratégica, como redução de custos, economias de escala, diversificação da produção, distribuição em escala global de produtos ou serviços, sinergias entre as sociedades, ocupação de novos mercados, compartilhamento de atividades e recursos, economias de impostos, aproveitamentos de créditos fiscais, entre outros. ${ }^{323}$

De todo modo, o fundamental, em qualquer caso, é ficar demonstrado na justificação que a operação, seja por motivos de ordem econômica ou estratégica, está sendo realizada para atender ao interesse social, deixando claro quais os motivos pelos quais a operação pretendida mantém ou altera a missão e os objetivos da companhia e a razão pela qual essa alteração ou manutenção atua no melhor interesse da companhia. ${ }^{324}$ Isso, aliás, é evidente, porque o conteúdo de todas as deliberações em assembleia é balizado pela complexa e genérica noção do interesse da companhia, já que é no interesse

autorização societária para que então as administrações das companhias pudessem firmar o protocolo. Para esse fim, a justificação deveria constituir documento em separado e ser submetido à aprovação pela assembleia geral à parte do protocolo, e não de maneira unificada como vem sendo feito de modo sistemático na prática societária, abrindo espaço para cometimento de abusos. Vide também I. MUNIZ; A. CASTEllo BRANCO, Fusões e aquisições... cit., p. 127. Não obstante, a maioria da doutrina admite que a justificação e o protocolo sejam apresentados de maneira conjunta e num mesmo momento para aprovação dos acionistas, sem sequer cogitar a separação de tais documentos (vide N. EIZIRIK, A Lei das S/A comentada... cit., p. 233; A. LAMY FILHO; J. L. BULHÕES PEDREIRA, A Lei das S.A (pressupostos, elaboração, aplicação)... cit., p. 244; e M. CARVALHOSA, Comentários à Lei de Sociedades Anônimas, v. 4 , t. I cit., p. 253 e 266).

322 Cf. A. LAMY FILHO; J. L. BUlHÕes PedReIRA (Coord.), Direito das companhias, v. 2, cit., p. 1760; e N. EIZIRIK, A Lei das S/A comentada ... cit., p. 233.

323 Cf. N. EIZIRIK, A Lei das S/A comentada... cit., p. 234.

${ }^{324}$ E. F. DE PONTES, Incorporação de ações no direito brasileiro... cit., p. 38. A. PÉREZ TROYA completa dizendo que somente a incorporação devidamente justificada legitima a diluição da participação de todos os sócios e apenas se cumprida essa exigência é que se justifica a inexistência do direito de preferência na incorporadora (La determinación del tipo de canje... cit., p. 48). 
da companhia que deve ser proferido o voto dos acionistas nas assembleias conforme disposto no art. 115 da Lei das S.A. Portanto, o exame de qualquer das técnicas de reorganização deve, sempre, ser feito à luz da noção nuclear do interesse social. ${ }^{325}$

De maneira muito resumida, sabemos que o interesse social pode ser definido como o interesse dos sócios enquanto sócios (uti socii) para realização do escopo comum da sociedade. ${ }^{326}$ Esse interesse comum é aquele que transcende os interesses individuais (uti singuli) dos acionistas e se consolida em um interesse que abrange a todos eles enquanto permanecerem na condição de sócios, ${ }^{327}$ ainda que tal interesse não possa colidir com o interesse geral da coletividade. ${ }^{328}$

Por ser uma comunhão voluntária de interesses, a sociedade por si só já constitui uma comunhão de escopo. Essa comunhão de escopo se coordena com um interesse comum a todos os participantes de modo que, em cada participante, pode-se identificar um interesse extrassocial e um interesse que, embora seja próprio de cada um, é comum a todos. ${ }^{329} \mathrm{O}$ interesse comum que une os sócios é, justamente, a realização do escopo social, abrangendo o escopo-meio, que é o exercício da empresa consagrado no objeto da sociedade, e o escopo fim, que é a obtenção de lucro e sua distribuição entre os sócios. $^{330}$

Por essa razão, o interesse social pode se desdobrar em várias etapas: interesse de que o patrimônio da sociedade seja utilizado para consecução do objeto social, interesse

325 Vide, nesse sentido, L. G. P. B. LEÃES, Incorporação de companhia controlada... cit., p. 89.

Não se pretende realizar um estudo vasto e aprofundado das inúmeras posições e escolas que procuram definir o interesse social, o que seria absolutamente inviável para o escopo deste trabalho. A definição que apresentamos aqui é apenas uma noção do conceito que será instrumental para a verificação do interesse social em operações de reorganização societária e para a análise que se fará nos demais trechos deste trabalho, deixando de lado a longa discussão entre as diferentes correntes de institucionalistas e contratualistas.

327 É possível que os sócios tenham outros interesses comuns, mas que não digam respeito a sua qualidade de sócios, como, por exemplo, sócios que sejam todos membros de uma mesma família. Tais interesses que não dizem respeito à condição de sócio não estão compreendidos na ideia de interesse social (E. VALlADÃo A. e N. FRANÇA, Conflito de interesses, São Paulo: Malheiros, 1993, p. 58).

328 L. G. P. B. LEÃES, Comentários à Lei de Sociedades Anônimas, v. 2, São Paulo: Saraiva, 1980, p. 248; e E. VALlADÃO A. e N. FRANÇA, Conflito de interesses, cit., p. 56-57. No mesmo sentido, A. LAMY FILHO e J. L. BULHÕES PEDREIRA entendem que prevalece um interesse contratualista-organizacional, segundo o qual, embora o interesse social se identifique com o interesse dos sócios, requer que o acionista controlador exerça o poder de controle tendo em vista a função social da empresa (Direito das companhias, v. 1, cit., p. 403). 
para obtenção de lucros e interesse para divisão dos lucros entre os sócios. ${ }^{331}$ Pergunta-se, portanto, se o legislador brasileiro teria privilegiado um desses interesses em detrimento dos demais, notadamente em vista de normas de caráter institucional da empresa admitidas pela nossa Lei das S.A. A análise da Lei das S.A. nos mostra, todavia, que essas normas de caráter institucionalista coexistem com regras que detalham a distribuição de dividendo mínimo obrigatório e regulamentam a criação de reservas pela companhia, de modo que entendemos não ter havido uma escolha óbvia pelo legislador de qual interesse a companhia deveria privilegiar, seja a máxima eficiência produtiva da empresa ou a obtenção de lucros para distribuição de dividendos. Por essa razão, o interesse social abrange qualquer interesse que diga respeito à causa do contrato de sociedade, seja um interesse para melhorar a eficiência da empresa, a maximização dos lucros ou a maximização dos dividendos, ${ }^{332}$ mas sempre levando em conta que o interesse final é a obtenção e maximização de lucros a serem distribuídos entre os acionistas. ${ }^{333}$

O interesse social deve, então, atender aos interesses externos da sociedade apenas na medida em que tais interesses não conflitem com os objetivos presentes e futuros dos sócios, que são os de maximizar a prosperidade, rentabilidade e distribuição equitativa dos resultados da sociedade em longo prazo. ${ }^{334}$

Feita essa breve introdução sobre a noção de interesse social, é fundamental então explorarmos como esse conceito pode, de alguma maneira, afetar a determinação da relação de substituição de ações já que impede a negociação de uma relação de troca que se mostre contrária a ele. Isso porque, considerando os impactos profundos que as operações

331 Cf. F. Galgano, Tratatto di Diritto Commerciale e di Diritto Pubblico Dell'Economia, La Società per Azioni, Padova: Cedam, 1984, v. 7, p. 57-58.

332 Cf. E. VAlladẽo A. e N. FRANÇA, Conflito de interesses, cit., p. 59-62.

333 Cf. Fran MARTins, Comentários à Lei de Sociedade Anônima, v. 2, t. I, 2. ed., Rio de Janeiro: Forense, 1984, p. 77-78; e A. LAMY FILHO; J. L. BULHÕES PEDREIRA (Coord.), Direito das companhias, v. 1, cit., p. 1114. Ver também L. MENGONI, ao dizer que não é possível distinguir o interesse social do interesse dos sócios, no qual sobreleva o intuito comum de, por meio da sociedade, obter maior rentabilidade com o mínimo de investimentos necessários (Appunti per una revisione della teoria sul conflitto di interessi nelle deliberazioni della società per azioni, Rivista delle Società, 1956, p. 442). Ainda, vide M. CARvalhosa, Comentários à Lei de Sociedades Anônimas, v. 2, cit., p. 460.

334 Nesse sentido, E. S. MUNHOZ, Desafios do direito societário na companhia aberta: avaliação dos sistemas de controle diluído e concentrado, in: L. S. ARAGÃO; R. R. M. DE CASTRO (Org.), Direito societário - desafios atuais, São Paulo: Quartier Latin, 2008, p. 134. Essa concepção acaba por, inclusive, aproximar o contratualismo do institucionalismo, já que não há mais a preocupação somente com o sócio atual da empresa, mas também com interesses externos que futuramente poderão ser internalizados. No mesmo sentido, vide M. CARVAlHosA, Comentários à Lei de Sociedades Anônimas, v. 2, cit., p. 456. 
de incorporação têm sobre as sociedades, não basta uma justificação genérica da decisão afirmando sua congruência com o interesse social. Mais do que isso, é necessário justificar o interesse social em cada operação proposta e demonstrar que a participação que se atribui aos sócios no complexo unificado das sociedades não constitui uma redistribuição de recursos de caráter expropriatório aos minoritários. ${ }^{335}$ É o que pretendemos discutir nos itens a seguir.

\subsection{Critérios para Atendimento do Interesse Social em Operações de Incorporação}

Para uma primeira corrente mais tradicional, o interesse social nas operações de incorporação identifica-se com a conservação do patrimônio originalmente detido pelos acionistas, garantido por meio da congruência da relação de troca estabelecida em tais operações. Portanto, para que uma operação de incorporação possa ser considerada em consonância com o interesse social, sua concretização deve conferir aos sócios das sociedades envolvidas o mesmo patrimônio que detinham antes da realização da operação, proporcionalmente atribuídos na sociedade incorporadora. ${ }^{336}$

De outro lado, uma segunda corrente critica essa imposição considerando que equiparar o interesse social apenas à manutenção do patrimônio dos sócios é demasiadamente restritivo, além de poder, em algumas hipóteses, prejudicar a busca da maximização dos benefícios dos acionistas. De acordo com essa posição, o atendimento ao interesse social exige que uma operação de incorporação possa ser realizada apenas se os lucros ou fluxos de caixa da sociedade pós-fusão forem proporcionalmente maiores do que aqueles das sociedades originárias. ${ }^{337-338}$

335 Nas palavras de A. PÉREZ TROYA, La determinación del tipo de canje... cit., p. 77. A autora complementa ainda dizendo que as operações de fusão, embora sejam um excelente mecanismo de crescimento, não significam que se realizem sem contrapartidas para os acionistas, pois, ainda que não exijam necessariamente contrapartidas financeiras, o redimensionamento empresarial vem a custo da diluição da participação acionária na sociedade resultante (idem, p. 15).

336 Nesse sentido, vide, por exemplo, C. SAntagata, La Fusione Tra Società... cit., p. 273 e ss. Vide também a exposição de A. VICARI sobre diversos autores que adotam essa posição mais tradicional (Gli Azionisti... cit., p. 2).

337 Cf. A. VICARI, Gli Azionisti... cit., p. 3-4. 
Essa segunda tese é criticada por algumas razões. Em primeiro lugar, pela dificuldade de se verificar, no momento da realização da operação, se os benefícios esperados pelos administradores em suas avaliações poderão ser de fato realizados e, portanto, se tais administradores cumpriram seus deveres fiduciários de buscar a melhor operação da companhia. Em segundo lugar, porque o interesse social poderia nesses casos ser definido em termos genéricos, abrindo a possibilidade de se buscar uma maximização dos resultados tanto de longo prazo quanto de curto prazo. ${ }^{339}$

A. VICARI, por sua vez, em análise mais detalhada, identifica o interesse social nas operações de incorporação como aquele ligado à maximização da rentabilidade do acionista na sociedade. ${ }^{340}$ Embora essa definição, a princípio, não se afaste da noção genérica de interesse social que discutimos acima, continua o autor dizendo que essa maximização de rentabilidade se assenta sobre dois pressupostos: (i) em primeiro lugar, o aumento da capacidade da sociedade de produzir lucros ou fluxos de caixa futuros que sejam superiores ao que seria alcançado se as sociedades continuassem atuando de maneira separada; $;^{341}$ e (ii) em segundo lugar, a conservação (e tentativa de aumento) da quota

338 A questão de ser mais adequado para assegurar a maximização dos benefícios aos acionistas tentar garantir o aumento dos lucros ou o aumento dos fluxos de caixa é uma questão ainda largamente debatida na doutrina de finanças. Aqueles que sustentam a utilidade da mensuração dos lucros dizem que mesmo fluxos de caixa positivos podem ser acompanhados de uma perda contábil e econômica. Por outro lado, aqueles que sustentam a tese da utilização dos fluxos de caixa criticam justamente o aspecto contábil da apuração dos lucros, sujeitos a uma série de escolhas por parte dos contadores e influenciados pelos princípios contábeis, sendo, de certa maneira, uma medida arbitrária.

339 Cf. A. VICARI, Gli Azionisti... cit., p. 5-6.

340 Cf. A. VICARI, Gli Azionisti... cit., p. 7. Vide também nesse sentido F. SCARDUlla, que identifica o interesse social como "il proposito delle singole società che decidono di fondersi si identifica con l'intento di assicurarsi, con la fusione, una maggiore produttività e quindi, in definitiva, di realizzare, con essa, l'interesse sociale" (La Transformazione e la fusione delle società, Milão: Giuffrè, 1989, p. 313); e também em sentido semelhante L. MENGONI, Appunti per una revisione... cit., p. 442.

341 Para apurar se houve ou não uma maximização da rentabilidade dos acionistas, o autor sugere utilizar como parâmetro o aumento do valor das ações, em vez de avaliar, em cada caso, se há ou não expectativa de aumento de lucros ou fluxos de caixa. Essa proposta tornaria mais palpável a discussão sobre o atendimento do interesse social em tais operações porque o valor das ações decorre de uma análise feita por todo o mercado e, portanto, não ficaria restrita às opiniões dos administradores envolvidos na operação. Além disso, a adoção desse critério resolveria tanto o problema da questão da escolha da taxa que seria utilizada para desconto dos valores de lucro e fluxo de caixa futuros como também a necessidade de se considerar o perfil de risco de cada empresa, papel que seria já desempenhado pelo mercado. Haveria, assim, uma inversão do ônus da prova segundo a qual, constatada uma redução do valor das ações, presumir-se-ia uma lesão ao interesse social de maximização da rentabilidade dos acionistas e caberia aos administradores demonstrar, em sede judicial, com base em construções técnicas alterativas, que a operação gerará benefícios aos acionistas, muitas vezes decorrentes de informações que são detidas pelos administradores e foram negligenciadas pelo mercado (A. VICARI, Gli Azionisti... cit., p. 20). Embora esse posicionamento seja bastante eficaz do ponto de vista prático, pois traz um critério objetivo sobre como mensurar se houve ou não aumento da rentabilidade dos acionistas, é inegável que também gera uma série de outros problemas. O primeiro 
proporcional de participação dos sócios na sociedade pós-incorporação ou, em outras palavras, a existência de uma relação de troca adequada e tendencialmente "máxima", conforme detalharemos em seguida. ${ }^{342}$

Ao contrário, caso não haja nenhuma alteração na capacidade da sociedade de produzir lucros ou fluxos de caixa incrementais ou caso seja fixada uma relação de troca mínima ou que seja tendencialmente "mínima", não se caracterizaria a maximização da rentabilidade dos acionistas e, portanto, restaria desatendido o interesse social. ${ }^{343}$

Nesse ponto, é verdade que poderiam ser feitas objeções no sentido de que a necessidade de maximização da rentabilidade ou do valor das ações como critérios necessários para que seja comprovado o atendimento ao interesse social não decorre da lei nem dos princípios gerais que regem as operações de incorporação e que, portanto, estariam sendo criadas restrições a esse tipo de operação sem fundamento legal. No entanto, entendemos que esse argumento não se mostra compatível, primeiramente, com o princípio básico de finanças, de acordo com os quais as operações de fusões e aquisições devem necessariamente criar valor para os acionistas. ${ }^{344}$ Em segundo lugar, essa posição tampouco se coaduna com os princípios do direito societário que regem também as operações de incorporação e segundo os quais o acionista controlador e os administradores

deles é que a utilização do mercado como avaliador da operação de fusão e do preço das ações só funcionaria para as companhias que têm suas ações cotadas nas bolsas. O segundo é que diversos outros fatores podem influenciar a cotação das ações de uma companhia de modo que seria bastante difícil dizer se o preço de tais ações reflete unicamente a avaliação do mercado sobre a operação em questão ou se leva em conta outros fatores que podem estar influenciando o preço das ações. Nesse caso, o fato de ficar a cargo dos administradores comprovarem em juízo os benefícios esperados com a operação poderia, inclusive, desestimular que algumas operações benéficas fossem realizadas por receio dos administradores de serem cobrados por uma manutenção do valor das ações no mercado. Por fim, o aumento do valor das ações não é uma medida perfeita para avaliar os ganhos de eficiência produzidos com a operação por uma série de razões: primeiramente porque se os investidores já esperarem que determinada companhia se torne parte de uma operação, a reação do preço das ações irá capturar apenas uma parte desses ganhos; segundo, porque nem sempre as avaliações do mercado são realizadas de maneira isenta; terceiro porque diversas crises já demonstraram a fragilidade do pressuposto dos mercados eficientes em que existe perfeita correlação entre o valor das ações e o aumento dos fluxos de caixa futuros das empresas (cf. R. J. GILSON; B. S. BLACK, The Law and Finance... cit., p. 262).

342 Cf. A. VICARI, Gli Azionisti... cit., p. 8.

343 Cf. A. VICARI, Gli Azionisti... cit., p. 9.

344 Vide nesse sentido R. A BREALEY; S. C. MYERS. Segundo os autores, a primeira consideração a ser feita em uma operação de incorporação é se há ou não um ganho econômico com a fusão, o qual apenas existe se as duas empresas juntas valerem mais do que separadas. Apenas se existir esse ganho haverá uma justificação econômica para realização da incorporação (Principles of Corporate Finance, 7th ed, McGraw-Hill, 2003, p. 929). Vide também nesse sentido O. E. WILLIAMSON, Mergers, acquisitions, and leveraged buyouts: an efficiency assessment, in: L. A. BEBCHUK, Corporate Law and Economic Analysis, Cambridge: Cambridge University, 1990, p. 3-4. 
devem atuar no interesse da companhia e gerir a sociedade com o escopo de gerar lucros, abstendo-se de promover operações que não tragam nenhum benefício para os acionistas. $^{345}$

Alinhada com o entendimento acima e fazendo uma justaposição entre os aspectos jurídicos e econômicos de uma operação de incorporação, A. PÉREZ TROYA entende que uma operação de incorporação atende ao interesse social quando a decisão for tomada em benefício de todos os sócios e no seu interesse comum e, portanto, que essa decisão possa ser considerada como uma medida adequada, necessária e proporcional para alcançar o fim a que se propõe. Em outras palavras, é necessário que fique demonstrada a congruência entre a busca do interesse da sociedade e a realização de uma operação de incorporação como meio para se alcançá-lo. ${ }^{346}$

Os critérios sugeridos pela autora permitem, de certa maneira, criar um quadro de análise das operações de incorporação que em muito coincide com aquele utilizado sob a perspectiva econômica para determinar o caráter eficiente ou ineficiente de tais operações. Do ponto de vista econômico, a avaliação da eficiência ou ineficiência de uma operação de incorporação resume-se, basicamente, a dois fatores. Em primeiro lugar, é necessário que a operação de incorporação traga algum tipo de sinergia ou benefício, ${ }^{347}$

345 Vide nesse sentido A. VICARI, Gli Azionisti... cit., p. 17. Corroborando essa posição, L. A. BIANCHI diz que o ordenamento jurídico enxerga a operação de incorporação como instrumento de criação de valor e não como uma técnica societária neutra a serviço de qualquer necessidade (Il Giudizio di “Congruità”... cit., p. 170).

346 Cf. A. PÉREZ TROYA, La determinación del tipo de canje... cit., p. 55.

347 Cabe aqui um pequeno esclarecimento sobre a utilização do termo "sinergia" ou da expressão "ganhos de sinergia", largamente utilizados no contexto de operações de incorporação. Cf. bem salientou E. F. DE PONTES, embora o termo ou a expressão não tenha nenhum significado jurídico específico, tem conteúdo técnico do ponto de vista da administração estratégica, o qual evidencia um compromisso preciso da administração com seus acionistas e com a companhia. Para se falar em sinergias, é necessário que a administração tenha em mente o conteúdo que essa ferramenta de gestão estratégica quer efetivamente dizer. Para se entender as sinergias, é necessário antes falar em missão, metas e objetivos de uma organização. Missão é a maneira e o método pelo qual o lucro da organização é buscado observando-se as influências de cada um dos constituintes societários (stakeholders) nas tomadas de decisão pela organização. Com base na missão definida, a organização traçará as suas metas e objetivos, que traduzem o modo como cada missão desenhada será implementada pela administração. Tais objetivos dividem-se em quatro categorias (i) performance; (ii) administração de riscos; (iii) objetivos sociais e filantrópicos, e, por fim, (iv) as sinergias. As sinergias, por sua vez, como um dos objetivos que devem ser buscados pela administração da sociedade, dividem-se em três outras espécies: (i) sinergias de natureza administrativa; (ii) sinergias de natureza funcional; e (iii) sinergias de natureza estratégica. Sinergias são compartilhamento de recursos entre áreas distintas de uma mesma empresa, mas esse compartilhamento não é, em todas as oportunidades, desejável. Pelo contrário, o compartilhamento de recursos também deve seguir os princípios da ciência da administração, sendo aplicados e calculados de maneira cuidadosa, sem precisarem ser buscadas a qualquer custo e a qualquer 
isto é, traga alguma vantagem e gere algum valor que não existiria caso as sociedades funcionassem de maneira isolada. ${ }^{348}$ Desse modo, uma operação de incorporação gera

tempo, sob risco de perdas futuras em competitividade. As empresas (ou, tecnicamente, as strategic business areas (SBA) das empresas) deverão escolher se preferem trabalhar com nível zero de sinergias (caso em que são chamadas de conglomerate firms em que a sinergia é evitada para que se extraia o máximo de cada SBA) ou se operarão com elevado grau de sinergia entre as diferentes strategic business areas (as chamadas synergistic firms nas quais se busca a coerência entre as diferentes SBA), sendo essa uma decisão a ser tomada pela administração junto com os acionistas e demais stakeholders. Em cada organização, existe um nível máximo de sinergias aceitável e a ser buscado (maximum acceptable sinergy level), além do qual elas passam a ser indesejadas. As sinergias, portanto, são modelos de negócios estabelecidos pela empresa junto com seus acionistas, fornecedores, credores e outros stakeholders, operacionalizada por meio de metas e objetivos para a administração. Dito isso, entendemos que uma operação de incorporação que invoque ganhos de sinergias como justificativa deve ser explicada e pormenorizada perante as metas e os objetivos traçados pela administração, por exemplo, no contexto de uma empresa que haja escolhido como meta trabalhar com nível baixo de sinergias (conglomerate firms) ou que já tenha ultrapassado o seu nível máximo de sinergias. Inclusive, o uso de sinergias como justificativa para concluir uma operação de incorporação já levou inúmeros conglomerados a uma perda de valor que deveria ter sido antevista pelos administradores, bem como existem inúmeros estudos de casos práticos de discussões judiciais em casos de sinergia que não se materializaram ou que não estavam alinhadas com o modelo de negócios das companhias envolvidas e que deveriam ter sido antevistas pelos administradores (Cf. I. ANSOFF; E. MCDONNEL, Implanting Strategic Management, 2. ed., Harlow, Essex: Prentice Hall, 1990, p. 132 e ss.; E. F. de Pontes, Incorporação de ações no direito brasileiro... cit., p. 35 e 36; Y. AHMUD; B. LEV, Risk Reduction as a Managerial Motive for Conglomerate Mergers, in: R. ROMANO, Foundations of Corporate Law, Nova York: Foundation Press, 2003, p. 232-233; e P. A. GAUGHAN, Merger, Acquisition and Corporate Restructutrings, 5 ed., Hoboken, NJ: Wiley \& Sons, 2011, p. 132-145). Por essa razão, entendemos que muitas vezes, quando os autores se referem à necessidade de demonstrar que a operação trará ganhos de sinergia, na verdade, referem-se não ao conceito técnico de sinergia, mas à necessidade de demonstrar a capacidade de haver qualquer vantagem ou benefício que gere valor adicional ao acionista. Nesse sentido, A. PÉREZ TROYA define as sinergias como a situação em que a soma de duas ou mais partes é maior do que as contribuições individuais e, por conseguinte, decorreria um resultado sinérgico de uma operação de incorporação de duas ou mais sociedades quando se formar um complexo de valor superior à soma das entidades envolvidas na operação. Essa criação de valor, que se projetará sobre o valor de mercado do complexo unificado, resultará do incremento de benefícios ou vantagens gerados pela integração em comparação com o funcionamento separado de cada sociedade (La determinación del tipo de canje... cit., p. 18).

348 Explicando a razão pela qual se realizam as operações de incorporação ou fusão, A. PÉREZ TROYA expõe que tais operações de justificam pela possibilidade de se conseguir um efeito de sinergia e as repercussões positivas de tais efeitos sobre os sócios das sociedades participantes (La determinación del tipo de canje... cit., p. 17). R. F. BRUNER, por sua vez, diz que as sinergias devem ser o foco central de qualquer operação de fusão ou incorporação por quatro razões: (i) a criação de valor decorrente das sinergias deve ser o objetivo fundamental de se realizar tais operações; (ii) antecipação da reação do mercado ao anúncio da operação em função das sinergias esperadas; (iii) desenvolvimento de estratégias de divulgação de tais sinergias aos investidores; e (iv) desenvolvimento da estratégia de integração das sociedades pós-operação depende das sinergias identificadas (Applied Mergers \& Acquisitions, New Jersey: Wiley Finance, 2004, p. 326-327). Graficamente, o resultado das sinergias pode se resumir à conhecida fórmula em que " $2+2=5$ ", expressando os efeitos multiplicativos e não meramente aditivos que podem ser gerados pelas operações de incorporação (cf. J. F. WESTON, The Determination of Share Exchange Ratios in Mergers, in: W. W. ALBERT; J. E. SEGALL, The corporate merger, Washington: Beardbooks, 2003, p 130). Essas vantagens podem ser as mais diversas, podendo ser representadas por novas oportunidades de investimentos, vantagens econômicas, aproveitamento de capacidades de gestão, economias de escala, economias decorrentes de integração vertical, integração de recursos complementares entre as empresas ou eliminação de ineficiências, principalmente decorrentes de má administração (vide R. A BREALEY; S. C. MYERS, Principles of Corporate Finance ... cit., p. 930-934). São, portanto, diversos os tipos de sinergias que podem ser obtidos em uma operação de incorporação, tendo a literatura usualmente as dividido entre: (i) sinergias operacionais, que são aquelas que 
valor aos seus acionistas apenas se as duas companhias envolvidas valerem mais juntas do que separadas e, por essa razão, a operação de incorporação que é incapaz de gerar qualquer benefício é, de pronto, considerada ineficiente sob a óptica econômica. ${ }^{349}$

A eficiência de uma operação de incorporação não decorre, no entanto, apenas do fato de poderem ser verificadas sinergias caso a operação seja concluída. Como segundo fator, é ainda necessário se verificar que não existem projetos alternativos que ofereçam maiores vantagens ou benefícios aos acionistas do que aqueles trazidos pela operação de incorporação. Assim, ainda que a operação de incorporação possa gerar algum benefício sinérgico para as sociedades, não será considerada eficiente se existirem alternativas aos acionistas que pudessem gerar maiores benefícios de modo que ambos os requisitos são condições sine qua non para que se comprove o caráter de eficiência de uma operação de incorporação.

Dessa análise, vê-se que uma operação de incorporação poderá ser considerada eficiente quando sua realização implicar a maximização da riqueza dos sócios (ou da rentabilidade dos sócios) de cada uma das sociedades que participam na operação. Essa maximização se dará quando forem cumpridas ambas as condições acima, isto é, quando a incorporação em questão, além de implicar uma vantagem aos acionistas, também constitua a opção mais vantajosa se comparada a outras possibilidades disponíveis para a administração. ${ }^{350}$

possibilitam aproveitar economias de escala (redução dos custos em função da quantidade produzida) ou economias de alcance (redução dos custos em função da complementaridade dos recursos); (ii) sinergias financeiras, que estão ligadas à criação de valor decorrente da redução da flutuação dos resultados de uma companhia por meio de uma diversificação de seus investimentos em diversos mercados; e (iii) sinergias competitivas, que possibilitam alcançar os objetivos da estratégia empresarial com um custo menor de desenvolvimento interno ou aquelas decorrentes do aumento do poder de mercado de uma organização (vide nesse sentido, R. J. GILSON; B. S. BLACK, The Law and Finance... cit., p. 258; e A. PÉREZ TROYA, La determinación del tipo de canje... cit., p. 18).

349 R. ROLL, por exemplo, expõe a situação de maneira bem clara: "If there were no value at all in takeovers, why would firms make bids in the first place? They should realize that any bid above the market price represents an error" (The Hubris Hypothesis of Corporate Takeovers, in: R. ROMANO, Foundations of Corporate Law, Nova York: Foundation Press, 2003, p. 234). No mesmo sentido, J. F. WESTON, The Determination... cit., p 130; e S. SCHWARTZ, Merger Analysis as a Capital Budgeting Problem, in: W. W. ALBERT; J. E. SEGALL, The corporate merger, Washington: Beardbooks, 2003, p. 140. Na prática, segundo R. J. GILSON e B. S. BLACK, os dados empíricos sustentam a conclusão de que na média as operações de fusão e incorporação aumentam o valor das sociedades combinadas e que as sinergias são as explicações para a maioria dos ganhos partilhados pelas sociedades (The Law and Finance... cit., p. 309).

350 Vide nesse sentido, A. PÉREZ TROYA, La determinación del tipo de canje... cit., p. 56. 
Esses parâmetros, utilizados para julgar a eficiência de uma operação de incorporação, coincidem, justamente, com os critérios de adequação e necessidade cuja utilização a autora propõe para avaliar a validade de determinada operação e sua identificação com o interesse social das sociedades.

Sob o primeiro aspecto, uma operação de incorporação poderá ser considerada uma medida adequada quando satisfizer o interesse social de maximização da riqueza dos sócios. O parâmetro de adequação não exige que a incorporação seja a única medida que permita alcançar o interesse social, e sim que seja uma das medidas capazes de atingir os objetivos e fins que são de interesse da sociedade. Esse critério, portanto, associa-se ao requisito mais elementar de todos, qual seja, pressupor um efeito de sinergia na operação, na ausência do qual a operação em questão nem poderá ser considerada eficiente, tampouco válida, já que traria como única consequência uma alteração no status quo do acionista sem nenhuma justificativa em contrapartida. ${ }^{351}$ A obtenção de um efeito de sinergia é, portanto, capaz de explicar por que os sócios levarão a cabo uma operação de incorporação que implicará uma diminuição relativa na sua participação no capital social da sociedade resultante. Pelo contrário, se não existir nenhuma vantagem ou benefício previsível, não haverá razão para que se dê seguimento a uma operação que levará à diluição da participação dos sócios. ${ }^{352}$

Corroborando essa visão, R. CLARK defende justamente que a restrição à liberdade do minoritário incorporado e o consequente realinhamento de sua participação societária são justificáveis na medida em que estejam sendo implementadas operações que gerem valor para o acionista, de modo que, em tais casos, os acionistas devem se sujeitar à decisão do controlador. ${ }^{353}$

Não é suficiente, no entanto, assegurar que a operação de incorporação é adequada conforme os parâmetros acima para que se possa considerá-la válida, assim

351 Idem, ibidem, p. 57. Vide também L. A. BIANCHI ao dizer que a alteração no status socii dos acionistas somente se justifica e encontra fundamento na consideração da operação de incorporação como instrumento técnico para perseguimento das finalidades que se reputem meritórias da tutela do ordenamento jurídico, o que, em tais operações, se traduz como um instrumento de criação de valor e maximização dos resultados da sociedade (Il Giudizio di “Congruità”... cit., p. 190).

352 Idem, ibidem, p. 19.

353 Corporate Law... cit., p. 506. 
como não se pode considerar como eficiente uma operação apenas por gerar um efeito de sinergia. Nesse ponto, entra em cena justamente o segundo critério a ser considerado, i.e., o da necessidade da operação. Para que uma decisão de promover uma operação de incorporação possa ser considerada como justificada e, consequentemente, válida, deve ser também uma medida necessária. A avaliação sob o critério da necessidade exige um juízo de congruência entre meios e fins, examinando-se, em cada caso, se não haveria uma alternativa melhor do que a incorporação para satisfazer o interesse social, ou, em outras palavras, certificando-se de que a operação de incorporação pretendida é o melhor meio para lograr o interesse social. Esse critério, obviamente, identifica-se com o segundo requisito necessário para se determinar a eficiência de uma operação de incorporação sob a perspectiva econômica, pois, na medida em que determinada operação não seja necessária, também não será eficiente se existirem alternativas melhores para conferir as mesmas vantagens aos acionistas e que gerem menores custos. ${ }^{354}$

Da conjugação dos fatores acima se vê que uma operação de incorporação poderá ser considerada válida apenas se conduzir a uma maximização da rentabilidade dos sócios de todas as sociedades envolvidas. ${ }^{355}$ Naturalmente, a ausência de vantagens advindas da operação, ou a existência de outras medidas que tragam maiores benefícios aos acionistas sem prejudicar os direitos de participação dos sócios, faria com que determinada operação de incorporação fosse considerada inadequada ou dispensável, ou, em outras palavras, inválida, porque não conduz à maximização da riqueza dos sócios. ${ }^{356}$

354 Cf. A. PÉREZ TROYA, La determinación del tipo de canje... cit., p. 57.

355 Nesse ponto, na literatura americana, é bastante comum vermos críticas às operações que beneficiam apenas os acionistas da incorporada, enquanto prejudicam os acionistas da incorporadora que acabam "pagando demais" pela conclusão da operação. Vide, por exemplo, R. A. BREALEY; S. C. MYERS, Principles of Corporate Finance... cit., p. 952-953; R. ROLL, The Hubris Hypothesis... cit., p. 233; M. C. JENSEN; R. S. RUBACK, demonstrando que a média dos retornos das empresas que adquirem outras (seja por tender offer ou por mergers) é significante menor do que a média dos retornos das ações incorporadas, sendo próximo de zero ou negativo quando se analisam apenas as fusões propriamente ditas (Market for Corporate Control: Scientific Evidence, in: R. ROMANO, Foundations of Corporate Law, Nova York: Foundation Press, 2003, p. 237-238); e, por fim, S. M. BAINBRIDGE, Mergers and Acquisitions... cit., p. 45-46.

356 Cf. A. PÉREZ Troya, La determinación del tipo de canje... cit., p. 58. Essas condições de validade das operações de incorporação dariam conta, portanto, de fazer a correspondência entre a validade jurídica da operação com sua função econômica, já que garantiriam a realização de operações economicamente eficientes ao mesmo tempo que descartariam incorporações ineficientes. No mesmo sentido, L. A. BEBCHUK diz que "from the perspective of efficiency, it is desirable that acquisition attempts survive if and only if the acquisition would produce efficiency gains" (Toward Undistorted Choice and Equal Treatment in Corporate Takeovers, 98 Harv. L. Review, 1984-1985, p. 1701). 
Por fim, é necessário ainda mais um cuidado a fim de garantir a validade de tais operações. Embora nenhuma incorporação ineficiente do ponto de vista econômico deva ser considerada válida juridicamente, nem toda operação economicamente eficiente é de pronto válida do ponto de vista jurídico, o que demonstra a limitação dos aspectos econômicos como os únicos necessários para dar conta da justificação de tais operações.

Para assegurar a validade de uma operação, é ainda preciso que ela possa ser considerada como uma medida proporcional levando em conta todos os interesses envolvidos na operação. O objetivo dessa análise é comparar os efeitos positivos da conclusão da operação contrastando-os com os efeitos negativos decorrentes do sacrifício dos direitos dos sócios das sociedades participantes que veem suas participações no capital social e seus direitos como acionistas drasticamente alterados com a conclusão da operação. Assim, uma incorporação deverá ser considerada válida quando, além de constituir uma medida adequada e necessária para atendimento do interesse social, os benefícios decorrentes da conclusão da operação superem os efeitos que tais operações projetam sobre os direitos individuais dos sócios. Dessa maneira, ainda que uma operação de incorporação seja eficiente, pode ser considerada inválida se o sacrifício individual que se exige dos sócios estiver fora de proporção quando comparado às vantagens advindas da operação, como poderia ocorrer nos casos em que os benefícios esperados da operação sejam relativamente escassos quando comparados a uma drástica modificação do status quo dos acionistas. ${ }^{357}$

Sendo assim, quanto maiores forem os benefícios sinérgicos esperados com a conclusão da operação, mais tolerável será a alteração aos direitos dos sócios, ao passo que quanto menores forem as vantagens esperadas, menos tolerável será que se alterem os direitos individuais dos sócios das sociedades participantes na operação. Não por outra razão, a justificação das operações de incorporação deverá ser maior e mais detalhada quanto maior for a redefinição dos direitos dos sócios afetados, como a perda de direitos de minoria, perdas de vantagens conferidas por eventuais ações preferencias ou ainda troca de controle resultantes dessas operações. ${ }^{358}$

\footnotetext{
357 Idem, ibidem, p. 59.

358 Nesse sentido, a jurisprudência de Delaware adota critérios mais rigorosos de revisão quando as operações de incorporação envolvendo companhias de capital disperso resultam em uma companhia que
} 
Ao lado da necessidade de maximização dos lucros ou fluxos de caixa em função dos benefícios gerados com a operação, passemos agora à análise do segundo aspecto que determina o atendimento ao interesse social: a conservação e tentativa de aumento da quota proporcional de participação dos sócios na sociedade formada após a conclusão da operação, analisando qual a extensão dessa exigência de acordo com a nossa legislação. ${ }^{359}$

Não é incomum encontrar referências na doutrina e em decisões da CVM de que "o princípio da incorporação é o de que os acionistas da sociedade incorporada passem a deter na sociedade incorporadora o mesmo valor que possuíam antes da incorporação, de tal sorte que cada acionista da sociedade resultante da incorporação deve receber, após a reunião dos patrimônios, o mesmo valor que possuía nas sociedades antes da incorporação". ${ }^{360}$ No mesmo sentido, CARVALHOSA entende que "é pelo valor comparativo das ações da sociedade cujas ações serão incorporadas e das ações da incorporadora que far-se-á a substituição dos títulos detidos pelos acionistas minoritários. Estabelece-se, assim, a justa contrapartida em ações de valor equivalente na sociedade incorporadora". 361 De acordo com esse entendimento, portanto, a relação de troca deveria ser atribuída em função dos patrimônios das sociedades incorporadora e incorporada, atribuindo a todos os sócios uma quota de participação no capital da sociedade pós-incorporação proporcionalmente idêntica àquela possuída nas sociedades originárias individualmente

tenha um novo controlador que consolide o poder de controle conforme o caso Paramount Communications, Inc. v. QVC Network, Inc. No mesmo sentido A. VICARI defende que nesses casos os administradores estão obrigados a negociar a relação de troca tendencialmente máxima (Gli Azionisti... cit., p. 71).

359 A tese da necessidade de conservação da participação proporcional é às vezes criticada por autores que sustentam que o interesse de todos os sócios na conservação de sua quota proporcional na sociedade pós fusão não corresponde ao interesse social, e sim a um interesse individual de cada acionista e que, portanto, a fixação de uma relação de troca inadequada geraria apenas uma lesão a um interesse individual. Essa ideia baseia-se, na verdade, no pressuposto de que quaisquer conflitos relativos às relações de troca não se dão no plano das sociedades, e sim dos acionistas. A essa posição se contrapõe a ideia de que se pode equiparar um dano à sociedade ao dano ao interesse comum ao patrimônio dos sócios e, dessa maneira, encontraremos, sim, um prejuízo à sociedade na redução da produtividade de seu capital social após a realização da incorporação. Assim, o dano individual dos sócios é, na verdade, um reflexo do dano ao interesse social (vide A. VICARI, Gli Azionisti... cit., p. 21-22).

360 Vide voto de Luiz Leonardo Cantidiano no Processo CVM n. RJ 2003/12770, rel. SEP, j. 26.12.2003. Vide também N. J. PARENTE, Maioria não basta, Revista Capital Aberto, São Paulo: Capital Aberto, fev. 2007, p. 52; D. KALANSKY, Incorporação de ações... cit., p. 51; e L. SILVA, O valor justo em incorporação... cit., p. 62.

361 M. CARVAlhosa; N. EIZIRIK, Estudos de direito empresarial... cit., p. 124. Vide também N. EIZIRIK, Temas de direito societário... cit., p. 320. 
consideradas de acordo com os valores comparativos das avaliações das sociedades envolvidas.

Esse tipo de relação de substituição de ações pode ser chamado de relação de troca "pura" ou "teórica" por ser aquela estabelecida mediante reconstrução dos patrimônios das sociedades participantes antes de sua conclusão da operação, sem levar em conta os diferentes interesses das sociedades, as partes envolvidas e as forças da negociação entre elas. ${ }^{362}$

A nosso ver, no entanto, o entendimento de que a validade de uma operação de incorporação requeira que ela seja desenhada tendo em conta uma relação de troca pura parece difícil de ser sustentado por uma série de razões. Em primeiro lugar, e acima de tudo, porque esse entendimento descarta desde logo toda a argumentação que fizemos acima a respeito da necessidade de que as operações de incorporação gerem benefícios para os acionistas para que possam ser válidas. Se a relação de substituição devesse ser determinada apenas com base no valor dos patrimônios das sociedades individualmente consideradas, pareceria dispensável toda a análise dos benefícios resultantes da operação de incorporação e sua forma de distribuição entre os acionistas, o que, como vimos, é também um dos requisitos para validade de qualquer operação de incorporação. Mais do que isso, admitir operações de incorporação que tenham que necessariamente garantir o mesmo "valor" aos acionistas poderia fazer com que operações ineficientes fossem consideradas válidas, pois seria possível legitimar operações que não geram nenhum valor aos acionistas apenas porque foi mantido o "valor" das suas respectivas participações. ${ }^{363}$

Em segundo lugar, a utilização desse critério não parece se adaptar à larga aceitação de que a relação de troca está sujeita ao princípio da liberdade contratual discutida nos capítulos antecedentes, a qual não se reduz apenas à liberdade das partes na escolha dos critérios de avaliação de cada companhia, mas inclui também a possibilidade de que outros critérios e fatores sejam utilizados para determinar os termos da relação de troca, inclusive aqueles que levem em conta os benefícios gerados com a operação e a maneira de distribuição entre os sócios.

\footnotetext{
362 Cf. L. A. BIANCHI, Il Giudizio di "Congruità"... cit., p. 96; e L. GUATRI, apud A. VICARI, Gli Azionisti... cit., p. 8.

363 Cf. A. PÉReZ TROYA, La determinación del tipo de canje... cit., p. 26.
} 
Do contrário, adotada a posição que defende uma relação de troca pura, uma vez feitas as devidas avaliações das companhias, estaríamos reduzindo a determinação da relação de substituição de ações apenas a uma operação matemática de proporcionalidade, não condizente, portanto, com a lógica da liberdade contratual e com o caráter negocial da sua determinação o que, inclusive, corresponde ao aspecto negocial mais intenso das operações de incorporação e que marcam justamente a sua natureza jurídica. ${ }^{364}$

Por fim, vimos que não há nenhuma exigência expressa pela Lei das S.A. de que haja avaliação por peritos de ambos os patrimônios envolvidos na operação. Dessa maneira, dispensadas as avaliações de todas as companhias envolvidas pela própria Lei das S.A., não parece ser cabível defender a exigência de que a relação de troca tenha que ser, necessariamente, estabelecida com base na comparação entre tais patrimônios. ${ }^{365}$ Além disso, é possível que o método de avaliação da companhia resultante seja distinto daqueles utilizados para avaliar as companhias envolvidas na operação de incorporação. Como garantir, então, uma manutenção do valor que os acionistas detinham nas companhias antes da conclusão da operação na sociedade resultante do negócio de acordo com os critérios previamente utilizados?

A análise dos pontos acima nos mostra, portanto, o aspecto secundário que as avaliações dos respectivos patrimônios das sociedades têm na determinação da relação de substituição de ações. Embora tais avaliações sejam necessárias para justificar a relação de troca e indubitavelmente influentes nessa negociação, a determinação da relação de troca

364 Cf. F. SCARDULLA, não se deve afirmar com fundamento "che a base del rapporto di cambio si ponga 'il raffronto obiettivo tra le situazioni patrimoniali' e che esso sia frutto di 'un calculo matematico che non deve lasciare adito ad alcuna discrezionalità', basato sulle risultanze delle situazione patrimoniali delle singole società, per cui l'esattezza del rapporto di cambio consisterebbe nella congruità dello stesso rispeto alla situazione patrimoniale. Così argomentando si dimentica che se 'si riconosce l'autonomia dei soci nel valutare l'affare', questa autonomia [...] deve trovare fondamento oltre che nella verifica della congruità, basata sull'esattezza dei dati puntualizzatti nella situazione patrimoniale [...], anche nella possibilità di una valutazione discrezionale del rapporto di cambio" (La Transformazione... cit., p. 390-391).

365 Nesse ponto, é preciso mencionar a posição de CARVALHOSA de que o fundamental é que haja avaliações conjuntas e contemporâneas dos dois patrimônios, utilizando-se, rigorosamente, no mesmo período, o idêntico critério para ambas as avaliações, de modo que permita uma justa e equânime relação de substituição (M. CARVALHOSA; N. EIZIRIK, Estudos de direito empresarial... cit., p. 124). Vide também N. J. PARENTE, Maioria não basta... cit., p. 52. No direito português, R. VENTURA chega a afirmar que a imposição da relação de troca sobre os acionistas deve se basear no valor real das participações (Fusão, cisão, transformação... cit., p. 78). No mesmo sentido D. C. GONÇALVES, Fusão, cisão e transformação... cit., p. 145, embora ambos os autores não definam precisamente o que seja esse valor real. 
não decorre imediatamente do confronto simples entre patrimônios da incorporada e incorporadora. ${ }^{366}$

Seguindo essa linha de raciocínio, dissemos acima que A. VICARI entende que o atendimento ao interesse social exige a determinação de uma relação de troca adequada e tendencialmente "máxima". Vê-se aqui, de pronto, que a menção a uma relação de troca tendencialmente "máxima" opõe-se, justamente, à chamada relação de troca "pura" ou "teórica". Em tais casos, reconhecem-se os interesses conflitantes das sociedades envolvidas e suas habilidades de negociação que podem fazer com que as partes se descolem da relação de troca pura e fixem uma relação de troca "efetiva" ou "negocial".

Essa relação efetiva, por sua vez, deriva de um confronto de interesses no qual as partes, em primeiro lugar, colocam lado a lado seus argumentos e seu poder de negociação e, em segundo lugar, valem-se de outras avaliações com base em pressupostos por ela construídos e que podem induzir ou convencer a outra parte a aceitar uma relação de troca diferente da relação de pura. Ainda, a relação de troca pode ser muitas vezes afetada pelas diferentes expectativas negociais que os grupos de controle tenham das sociedades envolvidas na incorporação, de modo que seu valor efetivo resultará do confronto das avaliações de cada sociedade de maneira que favoreça uma ou outra sociedade envolvida na operação. ${ }^{367-368}$

$\mathrm{O}$ atendimento ao interesse social, portanto, requer que seja estabelecida uma quota de participação proporcional dos sócios que seja tendencialmente máxima para cada sociedade, mas sem a exigência de que exista uma confrontação pura dos valores dos patrimônios sociais na determinação da relação de substituição de ações. ${ }^{369}$

366 Cf. L. A. BIANCHI, Il Giudizio di “Congruità”... cit., p. 94. Em outra passagem, o autor defende que a atribuição do valor da relação de troca não depende de técnicas neutras de avaliação de patrimônio, mas leva em conta a relação entre os sócios e a conciliação dos diferentes interesses sociais das empresas (idem, p. 156).

367 Cf. L. A. BIANCHI, Il Giudizio di "Congruità"... cit., p. 96; e L. GUATRI, apud A. VICARI, Gli Azionisti... cit., p. 8 .

368 Uma relação de troca diferente do que seria uma relação de troca pura também pode ser obtida justamente em uma situação em que não há nenhuma negociação, isto é, em situações entre companhias controladoras e controladas em que a ausência de autonomia de uma das partes acaba distanciando-a do que seria uma relação de troca pura baseada no confronto do seu patrimônio. Tais problemas serão analisados adiante no item 3.2.

369 A. VICARI, Gli Azionisti... cit., p. 8-9 e 134-135. 
Cabe então indagar em que hipóteses a negociação de uma relação de troca mínima ou tendencialmente mínima - seja porque o patrimônio da sociedade é subavaliado, seja pelo fato de que os sócios das sociedades receberam uma quota de participação inferior àquela que têm direito - pode ser tida como válida e alinhada com o interesse social. Como dito acima, o aumento da rentabilidade dos acionistas necessário para assegurar o atendimento ao interesse social pode decorrer tanto de um aumento de sua quota proporcional de participação na sociedade resultante quanto do aumento da capacidade da sociedade resultante de produzir lucros ou fluxos de caixa futuros. Assim, a negociação de uma relação de troca mínima ou tendencialmente mínima pode ser considerada legítima sob a condição de que ainda assim seja garantido um retorno à sociedade que a concedeu (em termos de maiores lucros ou fluxos de caixa futuros) marginalmente superior à diminuição de sua participação na sua quota proporcional decorrente da fixação de uma relação de troca mínima, de modo que a perda na quota proporcional seja compensada pelo incremento dos seus benefícios futuros, levando de qualquer maneira à maximização da rentabilidade do acionista. ${ }^{370}$

Seguindo essa linha de raciocínio, A. SEQUEIRA MARTIN argumenta que existe certa discricionariedade dos administradores para elaborar a relação de troca das ações, ainda que essa discricionariedade deva estar embasada em critérios lógicos e condicionados a uma valoração real de todos os patrimônios sociais. Dessa maneira, uma operação de incorporação não poderia ser impugnada apenas por uma disparidade nos critérios de avaliação utilizados, nem muito menos por falta de uma correspondência matemática com o valor das avaliações das sociedades comparadas com a avaliação da sociedade resultante da incorporação ou tampouco por existir certo grau de subjetividade na avaliação dos patrimônios, sempre que essa discricionariedade seja marginal e a relação de troca tenha tomado como base o valor patrimonial real, independentemente dos critérios que tenham sido utilizados. ${ }^{371}$

$370 \quad$ Idem, ibidem, p. 75-76.

371 Nas palavras do autor: "Existe, pues, una certa discrecionalidad de los administradores al elaborar el tipo de canje, si bien es certo que há de sustentarse em criterios lógicos, condicionados a elaborar uma valoración real de los patrimonios sociales [...], que eliminam cualquer arbitrariedaded" e continua dizendo que "la aprobación del acuerdo de fusión no podría así ser impugnado simplesmente por disparidade con los criterios de valoración utilizados [...], ni mucho menos por una falta de correspondencia matemática con el valor que se desprenda del balance ordinário o del balance de fusión, y ni siquiera por existir un certo grado de subjetividade en la valoración del patrimonio, siempre que la 
SANTAGATA, por sua vez, embora defenda que a relação de troca deva ser inferida da situação patrimonial das sociedades e que os sócios devem ser tutelados nos casos em que há lesão ao seu patrimônio quando a relação de troca acarretar uma participação na sociedade incorporadora menor do que aquela que resultaria da efetiva relação de valores entre o patrimônio das sociedades que se fundem, ${ }^{372}$ admite que uma divergência no valor patrimonial é admissível em relação àquelas variações que são dependentes da diversa utilidade que os bens concretos poderão revestir em relação à nova composição patrimonial que se realiza como efeito da incorporação. ${ }^{373}$ Dessa maneira, embora o autor seja, a princípio, defensor de uma relação de troca pura, admite expressamente que algumas diferenças podem existir em função das especificidades da operação e da utilização dos bens da sociedade no contexto da nova sociedade.

Nesse ponto, é bastante interessante avaliar as discussões havidas na Espanha em que o art. 25-1 da Ley 3/2009 estabelece, sem nenhuma correspondência com a Diretiva 2011/35, que a relação de troca "se determinará sobre a base do valor real do patrimônio social", dando a entender que as operações de incorporação deveriam ser construídas com base em uma relação de troca pura. ${ }^{374}$

Interpretando essa disposição de lei, há aqueles que entendem que a relação de troca pode ser livremente convencionada entre as diferentes sociedades como se a

discrecionalidad sea marginal y el tipo de canje haya tomado como base determinante el valor patrimonial real [...] e independentemente de cuáles hayan sido los criterios utilizados, que, además, no tienen tampoco por qué ser los mismos para todas las sociedades" (apud A. PÉREZ TROYA, La determinación del tipo de canje... cit., p. 25). No mesmo sentido, LARGO entende que "la relación de canje no es únicamente el cociente que resulta de dividir para cada sociedade de las que concurran en la fusión el número de acciones, participaciones o cuotas sociales en general, de la sociedad absorbente o de nueva creación que se le asignan, por el número de las propias; para la fijación de la relación de canje se toman en consideración otros factores que son objeto de negociación. Se entremezclan, pues, como se ha quedado señalado, criterios de índole objetiva con otros de matiz subjetivo. En todo caso, la base determinante deberá ser el valor patrimonial real (...) con independencia de los demás criterios utilizados" (apud A. PÉREZ TROYA, La determinación del tipo de canje... cit., p. 79). Vide também L. A. BIANCHI, Il Giudizio di “Congruità”... cit., p. 69 e G. TANTINI, Transformazione e Fusione... cit., p. 309310.

372 Para o autor, essa lesão poderia decorrer da má avaliação dos patrimônios das sociedades que participam da operação ou da fixação de uma relação de troca divergente daquela que resultaria da situação patrimonial das sociedades (La Fusione Tra Società... cit., p. 279-280).

373 La Fusione Tra Società... cit., p. 282-283.

374 Ley 3/2009: "Artículo 25 Tipo de canje - 1. En las operaciones de fusión el tipo de canje de las acciones, participaciones o cuotas de las sociedades que participan en la misma debe establecerse sobre la base del valor real de su patrimonio". Disposições semelhantes são encontradas na lei suíça como já apontamos, em relação a qual entendemos valer a análise feita pela doutrina espanhola dada a semelhança das disposições. 
legislação não tivesse imposto nenhum critério efetivo para a avaliação recíproca dos patrimônios, seja ela valor patrimonial ou outro qualquer, aqueles que entendem que a determinação da relação de substituição pode ser influenciada por critérios subjetivos sempre que tais critérios tenham papel secundário ou residual, apoiando-se na letra do artigo da lei que diz que a relação de troca deve ser construída "sobre a base" do valor real, de modo que o patrimônio das sociedades deve ser o parâmetro básico ou principal, mas sem que sejam excluídos outros critérios residuais, aqueles que entendem que essa norma, na verdade, inseriu um critério obrigatório de avaliação do patrimônio de modo que chegue a "um valor real" (geralmente usando o valor de patrimônio líquido ou patrimônio líquido ajustado) e aqueles que entendem que o valor dos patrimônios deve ser considerado nas avaliações que justificarão as relações de troca como fruto da convergência do interesse social. $^{375}$

Como se pode observar, mesmo nesse caso, em que a legislação foi bastante mais específica do que o usual no que tange à determinação da relação de troca, há extensa discussão sobre a correta interpretação da lei, não sendo evidente para todos os autores que a relação de troca decorra diretamente de um simples cálculo aritmético que leve em conta apenas o valor dos patrimônios envolvidos.

Em vista de todo o exposto, entendemos que a liberdade na determinação da relação de substituição de ações possibilita que a companhia incorporada possa negociar procurando a melhor avaliação do seu patrimônio, mas sem que uma negociação que considere seu patrimônio por valor inferior àquele que seja apurado mediante a avaliação dos peritos seja necessariamente inválida e abusiva. De outro lado, a sociedade incorporadora pode até considerar o valor do patrimônio incorporado como superior àquele apurado pela avaliação para determinar a relação de troca aplicável, pois pode entender que

375 Para as diferentes interpretações desse artigo, vide A. PÉREZ TROYA, La determinación del tipo de canje... cit., p. 77-94. Vide também J. SANCHEZ OLIVÁN, que entende que a imposição da lei espanhola é restritiva demais e, embora não seja possível desconsiderar o valor das avaliações, existem outros critérios subjetivos que podem ser considerados, além do fato de as próprias avaliações não serem totalmente objetivas (La fusión de sociedades. Estudio económico, jurídico y fiscal, 3. ed., Madrid: Editoriales de Derecho Reunidas, 1991, p. 124). 
a operação se justifica em vista de fatores estranhos à companhia incorporada quando isoladamente analisada ou em função de sinergias que decorrerão da própria operação. ${ }^{376}$

Assim, é possível que os sócios recebam ações da sociedade resultante que tenham valor patrimonial inferior ao valor que detinham anteriormente à concretização da operação, desde que esse valor esteja justificado em atenção ao interesse social. Da mesma maneira, também não há garantia de manutenção de um valor determinado caso tenham sido utilizados outros critérios para avaliação das companhias isoladas, pois a nova participação social pode exigir outros critérios de avaliação coerentes com a inserção dos sócios em nova perspectiva empresarial resultante da operação de incorporação.

Os sócios minoritários não têm, portanto, direito de manter inalterada a sua participação proporcional no capital social da sociedade resultante da operação e tampouco de manter intacto o valor absoluto de sua participação sob qualquer critério de avaliação que tenha sido utilizado. A proteção dos acionistas decorre, na verdade, da proibição de que sejam promovidos abatimentos injustificados de sua participação com a conclusão da operação, i.e., abatimentos que não estejam alinhados com o interesse social de maximização da rentabilidade dos sócios. Em outras palavras, os sócios têm direito a uma justa determinação do valor de sua participação na sociedade resultante, mas sem que isso signifique que devam, necessariamente, manter inalterada a própria posição patrimonial. ${ }^{377}$

Dessa maneira, parece carecer de fundamento o entendimento que subordina tais operações a uma leitura restritiva da lei, interpretando-a como se houvesse obrigatoriedade de equivalência dos patrimônios antes e depois da operação e impedimento de haver troca de ações por outras de valor imediatamente inferior sob os mesmos critérios ou que não siga uma divisão matemática do valor comparativo dos patrimônios das sociedades considerados de maneira isolada.

376 Cf. F. SCARDULLA, La Transformazione... cit., p. 395.

377 Nesse sentido, A. PÉrez Troya, La determinación del tipo de canje... cit., p. 93. Vide também L. A. BIANCHI, Il Giudizio di “Congruità”... cit., p. 167. Ainda, conforme sentença do Tribunal de Perugia, "na verdade, a mesma natureza jurídica da fusão e a variedade das articulações que compõem a operação impedem estabelecer de maneira axiomática que os sócios devam manter inalterada a própria posição patrimonial, como se a fusão não existisse" (apud A. PÉREZ TROYA, La determinación del tipo de canje... cit., p. 94). 
O que se deve exigir em qualquer caso é uma decisão tendente à maximização da rentabilidade dos sócios de modo que se possa considerar justificada a alteração das suas participações e dos seus direitos, sabendo-se, ao mesmo tempo, que a manutenção do valor inicial da participação não necessariamente garante a maximização da rentabilidade dos investimentos realizados pelos sócios. ${ }^{378}$

É evidente, no entanto, que essa busca pela maximização da rentabilidade deve fazer com que, sob algum critério de avaliação escolhido pela administração, as participações dos sócios tenham valor superior ao que teriam se não fosse realizada a operação de incorporação. Isso não significa dizer, por outro lado, que os acionistas têm direito a um determinado valor por eles detido antes da conclusão da incorporação. Sob esse enfoque, a doutrina que advoga a manutenção do valor das participações ou, ainda, do valor real das participações peca por dois motivos: o primeiro deles por não considerar os efeitos da própria operação sobre o valor das ações dos acionistas; o segundo, por raramente esclarecer a que valor real se referem, sem deixar claro se esse valor deveria ser apurado sob os mesmos critérios que foram utilizados para avaliar a sociedade a que antes pertenciam ou se outros critérios poderiam entrar em cena para avaliação após a realização da incorporação.

\subsection{Determinação da Relação de Substituição como Convergência dos Interesses Sociais}

No item anterior, discutimos como a noção de interesse social deve ser utilizada como fundamento de validade das operações de incorporação e como se pode analisá-lo de maneira mais concreta nas operações de incorporação. É necessário, agora, arrematar como essa noção funciona como delimitadora dos parâmetros da relação de troca.

378 Sobre esse ponto, R. M. ALLAN justifica a diminuição transitória do valor patrimonial do investimento com base nas sinergias esperadas de aquisições bem-sucedidas, de modo que a empresa resultante deve gerar resultados melhores do que a soma dos resultados das empresas operando de maneira isolada, demonstrando que a manutenção do investimento atual dos sócios não necessariamente leva a melhores decisões de investimento (Expansion by Merger, in: W. W. ALBERT; J. E. SEGALL, The corporate merger, Washington: Beardbooks, 2003, p. 106). Na mesma linha, F. SCARDULLA, ao defender que os sócios podem "accettare um concambio che potrebbe apparire per alcuni di essi sacrificale ma che, in realtà, si rivela conveniente [...] nella consapevolezza di un'accettazione calcolata di un minore temporaneo vantaggio in previsione de maggiori profitti futuri” (La Transformazione... cit., p. 392). 
Na linha da argumentação de A. PÉREZ TROYA, a ideia de interesse social e a correspondente necessidade de maximização da rentabilidade dos sócios têm particular relevância na determinação da relação de substituição porque, ainda que não sejam suficientes para determinar, por si sós, a relação de troca concreta, são fundamentais para delinear uma "relação de troca limite" para cada sociedade, de modo que, se a sociedade incorporadora entrega mais de suas ações, ou se a sociedade incorporada ou cujas ações são incorporadas admite menos ações em troca daquelas que entrega, a modificação do status quo do acionista pode não ser tolerável tendo em vista que o "custo" de realização daquela operação não tem uma contrapartida justificada. ${ }^{379}$

Essa premissa fixa, em consequência, uma banda de possíveis relações de troca que se delimita, de um lado, em torno do máximo de ações que a sociedade incorporada (ou que tem suas ações incorporadas) pode entregar em troca de uma ação da sociedade resultante e, do outro lado, o mínimo de ações que a incorporadora deverá exigir da incorporada (ou da sociedade que têm suas ações incorporadas) em troca de uma ação sua.

A concretização das respectivas relações de troca limite não deve derivar da mera aplicação de um ou vários métodos de avaliação destinados a apurar o valor de cada sociedade isoladamente, ainda que, ao mesmo tempo, não possa prescindir totalmente de tais avaliações. Para esses fins, considerando que o processo de integração das sociedades deve gerar um complexo unificado de valor superior à soma de todas as sociedades isoladas, será também necessário ter em conta nessa determinação dois tipos de avaliação adicionais. A primeira delas para determinar o incremento previsto como resultado da concretização da operação e uma segunda avaliação para apurar as possíveis vantagens decorrentes de outras operações alternativas à operação de incorporação proposta. ${ }^{380}$

Nesse sentido, vale retomarmos aqui o que dissemos no item 2.2.1 em relação aos critérios que podem ser utilizados para justificar a relação de troca proposta, os quais podem também levar em conta as projeções dos benefícios resultantes da unificação e na distribuição desses benefícios entre os acionistas das sociedades envolvidas conforme cada

379 A. PÉrez Troya, La determinación del tipo de canje... cit., p. 87-95. A noção de uma relação de troca "limite" também é seguida por K. BITZER, Probleme der Prufüng des Umtauschverhältnisses bei aktienrechtlichen Verschmelzungen, Pfaffenweiler: Centaurus-Verlagsgesellschaft, 1987, p. 48 e ss. 
sociedade gere tais benefícios. A nosso entender, como modo de justificar o atendimento ao interesse social e a necessidade de demonstrar que as operações de incorporação levam a uma maximização da rentabilidade dos acionistas, a determinação da relação de troca não só pode, como necessariamente deve, em todos os casos, considerar os patrimônios das sociedades de maneira conjunta e a distribuição dos benefícios resultantes dessa associação entre os acionistas. Entendemos, portanto, que as expectativas de benefícios futuros, bem como eventuais efeitos negativos da conclusão da operação, devem ser levados em conta na hora de determinação da relação de troca de ações, de forma a considerar a redistribuição do patrimônio em vista dos resultados esperados na sociedade após a conclusão da operação. ${ }^{381}$

A primeira avaliação, portanto, terá o papel de obrigar cada uma das sociedades a instituir uma "relação de troca limite" que permita demonstrar a participação de seus sócios também no incremento esperado do valor das sociedades após a concretização da operação. Essa exigência, inclusive, impõe limites à discricionariedade da maioria acionária na determinação da relação de troca, contestando as posições segundo as quais a relação de troca pode ser determinada de acordo com o livre-arbítrio das sociedades, prejudicando a tutela dos interesses dos minoritários em tais operações. ${ }^{382}$

Assim, e como consequência desse posicionamento, é possível que o máximo que a sociedade incorporada (ou que tenha suas ações incorporadas) possa estar disposta a entregar e o mínimo que a incorporadora deva exigir na concretização de uma operação de incorporação podem ser valores distintos do que resultaria se fossem somente consideradas as avaliações de cada uma das sociedades de modo independente. ${ }^{383}$

381 Nesse sentido, vide L. A. BIANCHI, Il Giudizio di “Congruità”... cit., p. 193. Vide também R. F. BRUNER que, ao discutir diferentes modelos para definição da relação de troca, diz que "the overarching implication of these models is that one must have a view about the value of the new firm" (Applied Mergers \& Acquisitions... cit., p. 589); R. LARGO GIL apud A. PÉREZ TROYA, La determinación del tipo de canje... cit., p. 27; e V. BRUDNEY, quando comenta a justiça da relação de troca das ações afirmando que "in the absence of any basis for identifying, quantifying, and compensating for the contribution (...) of each company to the combined venture, substantive equality is best effected by requiring each enterprise to share with the other in the proportion in which each contributes value to the new venture" (Equal Treatment of Shareholders in Corporate Distributions and Reorganizations, 71 Cal. L. Rev., 1983, p. 1103).

382 Cf. A. PÉREZ TROYA, La determinación del tipo de canje... cit., p. 89.

383 Idem, ibidem, p. 90. 
É verdade também que não se exclui de pronto a possibilidade de que a relação de troca seja determinada na proporção dos patrimônios de cada uma das sociedades envolvidas consideradas independentemente, desde que se comprove que essa distribuição não é infundada, pois, em tese, significaria que ambas as sociedades envolvidas participaram dos benefícios da operação de maneira proporcional aos seus atuais patrimônios contribuídos. Não obstante, na ausência de uma justificação adequada, essa determinação pode ser tão arbitrária como a decisão de distribuir aritmeticamente em partes iguais os efeitos das sinergias resultantes da operação. ${ }^{384}$

A segunda avaliação, por sua vez, deve também contribuir para a concretização das relações de troca limites uma vez que o máximo de ações que os sócios da incorporada podem entregar em troca das ações da incorporadora será menor quanto maiores forem as vantagens obtidas com projetos alternativos, ao mesmo tempo que o mínimo de ações que a incorporadora deve exigir em troca de uma ação sua será maior quanto mais elevados forem os benefícios esperados dos demais projetos. ${ }^{385}$ Dessa maneira, essa segunda avaliação exige contrastar os custos para os sócios decorrentes de tais projetos com os custos da operação de incorporação pretendida, de maneira que, quando existirem alternativas de igual rentabilidade, porém com menores custos, o máximo de ações a serem entregues pela incorporada será menor, bem como o mínimo de ações que a incorporadora deve exigir em troca das suas ações será maior.

Feitas tais análises, cada uma das relações de troca limite apuradas pelas sociedades envolvidas constituirá um parâmetro a partir do qual as operações de incorporação poderão ser realizadas em atendimento ao interesse social já que asseguram que o "custo" da operação tem uma contrapartida justificada, ou, o que dá no mesmo, tende a maximizar a rentabilidade das respectivas participações dos sócios envolvidos. ${ }^{386}$

Evidentemente que os limites da relação de troca, ainda que expressem os critérios de equivalência mínima dentro dos quais a incorporação é justificável, não concretizam a relação de troca específica sob a qual os sócios estão efetivamente dispostos

\footnotetext{
384 A. PÉREZ TROYA, La determinación del tipo de canje... cit., p. 90.

385 Quanto a essa segunda avaliação para determinação do custo de oportunidade, vide S. SCHWARTZ, Merger Analysis... cit., p. 140-143.

386 Cf. A. PÉREZ Troya, La determinación del tipo de canje... cit., p. 91.
} 
a aprovar a operação. Dentro dos respectivos parâmetros limites, a sociedade incorporada (ou que tenha suas ações incorporadas) pode desejar entregar menos de sua participação e a sociedade incorporadora pode exigir mais em troca da entrega de suas ações do que o mínimo estabelecido pela relação de troca limite que atenda aos respectivos interesses sociais de conduzir a uma maximização da rentabilidade dos acionistas. Nesse sentido, a relação de troca ideal para cada uma das sociedades será aquela que se concretize o mais longe possível da sua relação de troca limite. Na prática, porém, esse cálculo estará sempre condicionado pela relação de troca que faz com que a operação seja também justificada para a outra sociedade envolvida. ${ }^{387}$

O que se vê, portanto, é que o critério do interesse social e da necessária tendência de maximização da rentabilidade para o acionista definirá uma relação de troca máxima para uma sociedade que trará o maior benefício pelo menor custo, mas a qual estará sempre em função da relação de troca mínima exigida pelas demais sociedades. Dessa maneira, em cada operação de incorporação, delimitar-se-á um intervalo dentro do qual qualquer relação de troca que seja efetivamente negociada seria aceitável e justificável. $^{388}$

Nesse sentido, a existência para cada sociedade de um critério de equivalência mínimo que deva ser respeitado e de um critério de equivalência máximo a que tal sociedade possa almejar evidencia, finalmente, que a determinação da relação de troca surgirá de um conflito de interesses entre as sociedades envolvidas, cuja resolução requer um acordo de caráter negocial a fim de concretizar, dentro do intervalo de relações de troca aceitáveis, a relação de troca efetiva perante a qual as sociedades estão dispostas a levar adiante a incorporação. ${ }^{389}$

387 Essa ideia corrobora justamente a noção de se buscar uma relação de troca "tendencialmente máxima" que discutimos acima, a qual se identifica por ser aquela que, em comparação com o todo, busca a cada aporte por parte de seus acionistas aumentar a sua participação em relação ao patrimônio total das sociedades pós-incorporação (vide L. A. BIANCHI, apud A. VICARI, Gli Azionisti... cit., p. 8).

388 Nesse sentido, vide L. A. BIANCHI ao defender que existe uma ampla faixa de valores negociáveis entre um mínimo e um máximo, todas podendo ser consideradas como adequadas (apud A. VICARI, Gli Azionisti... cit., p. 8).

389 Cf. A. PÉREZ TROYA, La determinación del tipo de canje... cit., p. 92. No mesmo sentido A. VICARI, discutindo a possibilidade de atribuição de um sobrevalor aos acionistas da incorporada, defende a legitimidade da medida desde que esse prêmio "venga fissato, per quanto i senso favorelle alla società contraparte, comunque ad un livello superiore al valor 'negoziale' qualificabile como 'minimo' per la 
Logicamente, o conflito entre as sociedades será mais evidente e intenso quanto mais distantes forem os limites respectivos e menos intensos quanto mais próximos forem tais limites entre incorporadora e incorporada. $\mathrm{O}$ acordo negocial que venha a resolver esse conflito de interesses subjacente e do qual resultará a relação de troca concreta reflete, portanto, o ponto de convergência dos interesses distintos de todas as sociedades que participam da operação de incorporação, isto é, concretiza a relação de troca em relação a qual, legitimamente, os controladores de todas as sociedades entendem que é preferível que a incorporação se realize a que não se celebre. ${ }^{390}$

A posição acima corrobora o entendimento de que a relação de troca não se trata propriamente de um preço, o qual pode ser livremente negociado de maneira discricionária e subjetiva, mas também não se trata de mera declaração da maioria cujo conteúdo já foi predeterminado pela lei. É, na verdade, resultante de um caráter negocial uma vez que, como se viu, baseia-se na liberdade contratual entre as partes de determinar a relação de troca que melhor lhes convier, embora a sua subordinação a um limite determinado impeça que possa responder a outros interesses que não os da própria sociedade. Nesse sentido, ao mesmo tempo que se garante uma adequada tutela dos interesses dos minoritários, a operação não deixaria de constituir uma decisão de caráter empresarial, que não é alheia ao risco que qualquer decisão desse tipo apresenta. ${ }^{391}$

Dessa conclusão, decorre outra consequência importante: diferenciar o âmbito de atuação do controlador que não pode ser objeto de revisão judicial, haja vista que se

società che lo attribuisce: corretamente si è rilevato che in questo caso il concambio può essere qualificato como congruo ed il premio è strettamente riconducibile all'ambito delle concessioni che le società possono farsi reciprocamente nel quadro delle trattative funzionali alla determinazione del rapporto di cambio "negoziale"' (Gli Azionisti... cit., p. 76). R. F. BRUNER por sua vez defende a negociação da relação de troca dentro dos intervalos aceitáveis para ambas as companhias em direção ao que seja o "sweet spot" ou "win win situation" para ambas as companhias (Applied Mergers... cit., p. 590).

390 Cf. A. PÉRez Troya, La determinación del tipo de canje... cit., p. 92. No mesmo sentido, S. M. BAINBRIDGE expõe o caráter negocial da relação de troca dentro de determinado intervalo da seguinte maneira: "the acquirer typically will pay a control premium in an acquisition. There is no single right answer of how much of a premium should be paid in any given case. Instead, there will be a range of values that a buyer would be willing to offer and a range of values that a seller would be willing to accept. Assuming the two ranges overlap, where the parties end up will be solely a matter of negotiation. Given the importance of that issue, of course, those negotiations typically will be undertaken by the respective companies' CEOs, with input from financial advisors, and supervision by the board of directors" (Mergers and Acquisitions... cit., p. 73).

391 Cf. S. SCHWARTZ, Merger Analysis as a Capital Budgeting Problem... cit., p. 139-143; e J. F. WESTON, The Determination of Share Exchange Ratios... cit., p. 138. 
trata de uma decisão empresarial e sujeita a um juízo de oportunidade, e as decisões que podem estar sujeitas a alguma forma de controle externo por parte de terceiros. Nesse sentido, o direito que assiste aos sócios minoritários é o de solicitar que se analise se a relação de troca está ou não devidamente justificada, ou, mais concretamente, se está ou não dentro do intervalo dentro do qual qualquer relação de troca poderia justificar a alteração do status quo dos demais sócios. Assim, por mais que a relação de troca contratada possa não parecer a melhor para determinado acionista, se é possível justificar que ela está dentro do intervalo de relações de troca aceitáveis para aquela operação, não deveria haver revisão dos termos da operação sob pena de se estar interferindo em uma decisão de cunho puramente empresarial.

Sob a óptica econômica, BREALEY e MYERS explicam de forma bastante didática como as operações de incorporação devem necessariamente gerar valor para os acionistas e como os benefícios das sinergias decorrentes da operação podem ser divididos entre as diferentes companhias de maneira que ainda representem ganhos para todos os envolvidos. Em resumo, explicam os autores que os ganhos esperados com a incorporação devem ser comparados com o custo da aquisição da companhia alvo pela incorporadora. Para facilitar, os autores consideram uma cash out merger e definem como custo de aquisição o valor pago pela incorporadora para adquirir as ações da incorporada deduzido do valor de mercado da incorporada, i.e., o custo de aquisição corresponderia ao prêmio pago pela incorporadora. Exemplificativamente, consideremos que determinada incorporação tenha ganhos esperados de $\$ 100$ e um custo de aquisição de $\$ 50$. Nesse caso, os acionistas da incorporada já tiveram uma maximização do valor das suas ações ao realizar um ganho de $\$ 50$, correspondente ao prêmio pago a eles pela incorporadora. A diferença dos outros $\$ 50$, portanto, são os ganhos que seriam percebidos pelos acionistas da incorporadora com a conclusão da operação. ${ }^{392}$ Dessa análise se tiram duas importantes conclusões. A primeira delas é que qualquer ganho percebido pelos acionistas da incorporada seria, sob a perspectiva econômica, um custo para a incorporadora, que tem os seus ganhos diminuídos já que aumenta o pagamento feito aos acionistas da incorporada. ${ }^{393}$ A segunda conclusão é que a margem de negociação admitida está justamente na divisão entre as sociedades envolvidas dos ganhos esperados com a aquisição, pois, ainda que o

\footnotetext{
392 Vide R. A BREALEY; S. C. MYERS, Principles of Corporate Finance... cit., p. 938-939.

393 Cf. R. A BREALEY e S. C. MYERS, "their gain is your loss" (Principles of Corporate Finance... cit., p. 938).
} 
custo de aquisição fosse de $\$ 60$, a incorporadora teria um ganho de $\$ 40$ com a conclusão da operação, o que levaria de toda maneira a uma maximização do valor dos seus acionistas. Essa possibilidade demonstra, justamente, o intervalo permitido dentro do qual é possível que qualquer relação de troca seja negociada em atendimento ao interesse social, exatamente como expusemos acima sob a óptica jurídica da questão. ${ }^{394}$ É nesse sentido que F. SCARDULLA defende que a discricionariedade da determinação da relação de troca de ações se dá, justamente, em relação ao aspecto dinâmico da operação, i.e., aquele que considera os dois patrimônios envolvidos de maneira conjunta e a interação dos ativos após a realização da operação tendo em conta o desenvolvimento da empresa. ${ }^{395}$

Restariam desqualificadas, portanto, as operações que podem ser consideradas como ineficientes do ponto de vista econômico, como são aquelas que não geram nenhum efeito de sinergia e, portanto, não tendem a maximizar a rentabilidade dos sócios. Nesses casos, a única consequência da realização da incorporação seria a diluição da participação dos acionistas, isto é, existiria um "custo" sem nenhuma contrapartida justificada. 396

\subsubsection{Valor Justo em Operações de Incorporação}

A referência a um valor justo de incorporação é frequente na doutrina e em decisões e análises de precedentes da CVM, as quais, em geral, referem-se à necessidade

394 Nesse mesmo sentido J. F. WESTON expõe de maneira precisa: "For example, suppose the lower boundary [of value], without the merger, is $\$ 8$ million for [company] A and \$5 million for [company] B. With the merger, however, their combined value is $\$ 17$ million. The valuation problem is to assign the incremental $\$ 4$ million resulting from the merger between $\mathrm{A}$ and $\mathrm{B}$ to arrive at the terms of the merger. If A contributes something to the merger but B does not, the entire $\$ 4$ million increment of value should obviously be attributed and paid to A in the merger. But other possibilities exist. Suppose that A is very desirous of obtaining company B because of the synergistic effects that may be achieved. Suppose further that A recognizes the market developments in the industry are such that, without the merger between A and B, A will face a decrease in its share of the market. Suppose that B, on the other hand, could continue in its present industry or situation and still perform effectively. In other words, A needs B but B does not need A. In such a situation A would presumably choose to share some of $\$ 4$ million increment with B". Continua o autor afirmando que "this is not meant to imply that the gains from a merger would always be divided equally (...). The relative bargaining strengths of the participants in a merger and their relative contributions would influence the division of the economic gains" (The Determination of Share Exchange Ratios... cit., p. 131 e 137-138). 
de verificar, a cada caso, se a relação de troca proposta é justa como forma de proteção dos interesses dos minoritários. ${ }^{397}$

Primeiramente, é importante destacar que a Lei das S.A. jamais mencionou o conceito de um "valor justo" como requisito para a realização de uma operação de incorporação. Em segundo lugar, sabemos que esse conceito e a sua determinação em cada caso são, obviamente, carregados de subjetivismo e de dificílima apuração. ${ }^{398}$

Mesmo nos casos em que foi expressamente previsto na lei, como é o caso do art. 4. ${ }^{\circ}, \S 4 .^{\circ}$, da Lei das S.A. que exige o preço justo para cancelamento de registro de companhia aberta, a inserção desse critério sofreu diversas críticas por grande parte da doutrina, que vê nele excesso de subjetivismo, além de possíveis problemas que a referida redação pode gerar ao colocar a cargo de terceiros a avaliação da justiça da operação. ${ }^{399}$ A determinação da justiça do preço do ponto de vista do valor oferecido, como exigido pela Lei das S.A., seria problemática já que a oferta aos minoritários no contexto de fechamentos de capital não deixa de ser uma compra e venda mercantil entre particulares, não cabendo ao regulador, porque fora de seu escopo, opinar sobre o mérito dessas operações. $^{400}$

397 Nesse sentido, vide L. SILVA, O valor justo em incorporação... cit., p. 53. Vide também o voto do diretor Luiz Antonio de Sampaio Campos no Processo CVM n. RJ 2003/12770, rel. SEP, j. 26.12.2003: "se a relação de troca estabelecida for, nos dias de hoje, adequada e justa, nada há que se possa fazer e disso não deveria decorrer, inclusive, qualquer frustração [...]".

398 Mesmo na área das finanças, sabemos que a definição do melhor critério de avaliação de uma companhia é extremamente subjetivo e longe de ser uma ciência exata, pois diversos métodos igualmente justificáveis podem ser utilizados, bem como cada avaliador levará em consideração seus próprios critérios subjetivos no cálculo do valor da companhia. Além disso, os analistas, por mais capacitados que sejam, não conhecem todas as informações da companhia que avaliam, o que impede efetivamente de dizer se tal ativo está precificado de maneira justa (vide nesse sentido A. DAMODARAM, Investment Valuation... cit., p. 1-2; e E. MARTINS (ORG.), Avaliação de empresas... cit., p. 264). Se isso é verdade quando tratamos de uma avaliação de ativos isolados, ainda mais difícil é determinar o valor justo de uma relação de troca no contexto de uma operação em que duas partes estão em processo de negociação de acordo com seus interesses.

399 Cf. M. CARvalhosa, Comentários à Lei de Sociedades Anônimas, v. 1, cit., p. 172. Na audiência pública realizada em 15 de maio de 2001 para edição da Lei n. 10.303/2001, o jurista critica o projeto dizendo que a proposta de redação cria um conceito "absolutamente inexistente no mundo moderno, no mundo da econometria, o sentido de preço justo, que é um conceito moral e não jurídico". Vide também na mesma linha R. G. MOREIRA, Do preço justo no cancelamento de registro de companhia aberta, Revista de Direito Empresarial, n. 4, 2005, p. 189-190.

400 Os minoritários teriam a opção, portanto, de aceitar ou não a oferta, pautados em juízo próprio de conveniência e oportunidade, reforçando a regra máxima do capitalismo da oferta e demanda. 
Cabe então analisarmos se há ou não um valor necessariamente justo para as relações de troca em operações de incorporação que deva ser obrigatoriamente perseguido pelas partes na concretização de tais operações e, em caso positivo, como determiná-lo em cada caso.

$\mathrm{Na}$ esteira do que se entenderia por valor justo da incorporação, a maioria dos autores e das decisões da CVM que mencionam a necessidade de se obter uma relação de troca justa associam a justiça de uma operação de incorporação e da relação de troca com a equivalência e a manutenção do valor que o acionista detinha antes da operação na sociedade resultante após a conclusão da operação. ${ }^{401}$ Sobre esse ponto, no entanto, remetemos ao que expusemos no item 2.3.2.1 acima, afirmando que as operações de incorporação não necessariamente pressupõem a manutenção de certo "valor" ao acionista pelas razões que ali expusemos.

Refutada essa posição, a introdução do conceito de justiça como condição de validade de uma operação de incorporação parece carecer de substrato concreto para que possa ser utilizado como parâmetro das operações e posto à prova em qualquer situação.

É evidente que a ideia de justiça e a busca por reparar a parte que se sentir lesada sempre existirão no Direito, porém, entendemos que a utilização da expressão "valor justo" em operações de incorporações, como se se tratasse de um parâmetro único e universal de justiça, não agrega nenhuma proteção real aos acionistas na determinação da relação de substituição justamente por ser uma expressão que não pode ser aplicada de pronto e de maneira uniforme em qualquer operação e, o que é pior, pode levar ainda a ideias equivocadas de que necessariamente há, para todas as operações, um valor justo predeterminado a ser buscado.

E. F. DE PONTES remete a questão da relação de troca à teoria da justiça e igualdade formulada por Aristóteles segundo o qual o conceito de justiça envolveria,

401 Associando expressamente a manutenção do valor com o caráter de justiça de uma operação, M. CARVALHOSA entende que "é pelo valor comparativo das ações da sociedade cujas ações serão incorporadas e das ações da incorporadora que far-se-á a substituição dos títulos detidos pelos acionistas minoritários. Estabelece-se, assim, a justa contrapartida em ações de valor equivalente na sociedade incorporadora" (M. CARVALHOSA; N. EIZIRIK, Estudos de direito empresarial... cit., p. 124). Vide também N. J. PARENTE, Maioria não basta... cit., p. 52; e L. SILVA, O valor justo em incorporação... cit., p. 62. 
necessariamente, quatro termos - duas pessoas diante de dois elementos - , sendo que a relação de igualdade, equidade ou equivalência deveria ser uniforme entre as pessoas e os elementos em referência. No caso das incorporações, uma relação de troca justa envolveria duas pessoas (as companhias) e dois elementos (as ações cuja relação de troca é negociada) e a justiça decorreria de uma situação de equivalência entre as companhias. Nas palavras do autor,

toda a questão da relação de substituição (ou relação de troca) reside, precisamente, na fórmula aristotélica do justo: duas pessoas e dois elementos, as pessoas em face dos elementos, numa relação de equivalência. Assim e, portanto: as pessoas avaliam seus respectivos elementos e cada elemento é posto em oposição ao outro. Nessa balança imaginária, as pessoas buscam ver o ponteiro a meio-termo, e, em cada prato, as quantidades necessárias para o equilíbrio. Como em toda balança, a precisão do ponteiro oscila entre um espaço ideal, um certo eixo de equivalência. ${ }^{402}$

Segundo o autor, seguindo a teoria de D. C. GONÇALVES, o eixo de equivalência de uma operação de incorporação seria apurado de acordo com os princípios do statuo viae, o qual corresponde ao novo estado dos sócios na conjuntura das empresas modernas, em contraposição ao paradigma da empresa como sociedade isolada. No atual contexto do direito societário, a ação detida pelo acionista deixa de ser exclusivamente um bem móvel com caráter de título de propriedade e passa a ser visto como um título que encerra direitos e participações, mais afeito à disciplina do direito societário do que dos direitos reais. É, portanto, um ativo de renda variável que confere direitos de participação nos resultados de uma empresa contemporânea, dotado de uma característica fundamental de instabilidade que existe em função da necessidade de modular as expectativas do acionista aos interesses da empresa, do grupo ou do conglomerado. Esse novo estado de sócio foi denominado statuo viae justamente em função da abreviatura da frase latina status socii in statuo viae ostendit, i.e., o "o estado de sócio se apresenta como estado de mudança". 403

\footnotetext{
402 Cf. E. F. DE PONTES, Incorporação de ações no direito brasileiro... cit., p. 119.

403 Idem, ibidem, p. 44-48. No mesmo sentido, D. C. GONÇALVES reconhece a crise no paradigma clássico do status socii e reformula esse conceito para levar em conta a realidade dinâmica da empresa e da instabilidade dos investimentos (Fusão, cisão e transformação... cit., p. 372-373).
} 
Essa instabilidade do investimento se demonstra, entre outras formas, justamente nas operações de incorporação, nas quais os acionistas perdem suas ações originais para receberem novas ações da sociedade incorporadora. Dessa forma, o tal eixo de equivalência que deve ser buscado nas operações de incorporação assenta-se, justamente, sobre os limites que regulam o statuo viae, i.e., sobre os contornos que cerceiam a liberdade de alteração do investimento dos acionistas. Tais limites seriam (i) o princípio da identidade; e (ii) o princípio da tutela do investimento.

De acordo com o princípio da identidade, a participação social antes e após a modificação societária deve ser ontologicamente a mesma, mantendo a sua essência em um verdadeiro senso de continuidade. Para isso, exige-se a manutenção do valor econômico antes e após a modificação da posição relativa dos sócios perante os demais sócios, bem como a manutenção da equivalência material da participação, i.e., a manutenção de direitos que sejam materialmente (e não apenas formalmente) equivalentes aos detidos anteriormente pelo acionista.

Já o princípio da tutela do investimento compreende o sócio como um investidor que transmite para a esfera social um conjunto de seus interesses próprios. Assim entendido, a tutela do investimento visa a preservar as condições que sustentaram a decisão de investir, notadamente quanto às alterações não previstas ou não assumidas ao tempo da realização do investimento. Essa manutenção se liga, inclusive, à preservação de políticas, missões e metas da empresa. Esse princípio desdobra-se então em duas vertentes, uma positiva, que garante ao sócio nessas ocasiões o direito de reavaliar seu investimento e a possiblidade de ponderar de maneira esclarecida sobre a manutenção ou não de tal investimento, e outra vertente negativa, que confere ao sócio a possibilidade de abandonar a sociedade sem esforço excessivo. Nas operações de incorporação, a vertente negativa poderia ser encontrada no direito de retirada dos sócios e na impossibilidade de restrição à circulação de ações, enquanto a vertente positiva pode ser identificada, por exemplo, no regime do direito à informação. ${ }^{404}$

404 Vide D. C. GONÇALVES, Fusão, cisão e transformação... cit., p. 376-380; e E. F. DE PONTES, Incorporação de ações no direito brasileiro... cit., p. 50-54. 
Como se vê da exposição acima, o conceito de justiça da relação de troca não é evidente e não se limita a um valor específico que possa ser de pronto considerado justo ou injusto. Ao contrário, oscila dentro de um eixo de equivalência delimitado pelos princípios do statuo viae e de uma gama de valores que podem ser propostos pela administração. ${ }^{405}$ Essa noção de eixo de equivalência a ditar a justiça da relação de troca, inclusive, vai ao encontro do que discutimos no item anterior sobre a existência de um intervalo dentro do qual a relação de troca pode ser negociada em atendimento ao interesse social, de forma que qualquer valor assim negociado poderia ser considerado justo.

Dadas as dificuldades acima apresentadas para determinar se uma relação de troca é ou não "justa", é interessante avaliar outros critérios que podem ser utilizados para determinar a justiça de uma relação de troca e que não se ligam necessariamente ao valor da operação, e sim ao modo de sua negociação. Segundo R. ClARK, podemos apurar a injustiça de uma operação comparando-a a uma situação em que ela fosse realizada entre partes não relacionadas ou a transações feitas em um mercado competitivo. ${ }^{406}$ Dessa maneira, a justiça ou não de uma operação decorreria não do valor em si, e sim da garantia de um processo de negociação que simulasse uma transação independente e, por isso, a importância de garantir a lisura e a transparência de todo o processo envolvendo as incorporações. $^{407}$

Nessa linha de raciocínio, um processo de negociação entre partes independentes já foi utilizado pela CVM como critério definidor de preço justo e como modo de garantir a comutatividade das operações em diversas situações, como, por exemplo, para as ofertas públicas de cancelamento de registro, inclusive para a dispensa de laudos de avaliação, ${ }^{408}$ para os casos de avaliação de cumprimento dos deveres fiduciários

405 Cf. E. F. DE PONTES, ibidem, p. 41.

406 Corporate Law... cit., p. 147-148.

407 Esse conceito é também a essência do International Financial Reporting Standards (IFRS) ao regular a substituição dos registros de ativos e passivos avaliados pelo custo por seu valor justo, o qual passou a ser adotado e incorporado às práticas contábeis com a Lei n. 11.638/2007 e foi ratificado pelo Pronunciamento Técnico CPC 13. Segundo essa regra, o valor justo de um ativo é aquele que pode ser negociado entre as partes interessadas - conhecedoras do negócio e independentes entre si - livres de fatores que pressionem a liquidação de transações ou que caracterizem uma transação compulsória.

O Colegiado tem concedido a dispensa de apresentação de laudo de avaliação em ofertas públicas quando o preço justo a ser pago pelas ações de emissão de uma companhia puder ser aferido pelos acionistas com base em alternativas e parâmetros alheios ao laudo de avaliação, como se verificou, por exemplo, no (i) Processo CVM n. RJ 2003/7909 em que a requerente solicitou a dispensa de laudo de avaliação para fixação do preço justo invocando a fixação do preço das ações com base em transações 
dos administradores no estabelecimento de preço de emissão de ações, ${ }^{409}$ e também como forma de admitir negociações privadas de uma companhia aberta com suas próprias ações. ${ }^{410}$ Em movimento de reforço à proteção dos destinatários de oferta pública, a CVM reconheceu também a necessidade de independência do avaliador, afastando a avaliação elaborada por quem "possui participação relevante no capital da avaliada, ainda que através de empresa do seu grupo", situação em que a CVM julgou parecer "evidente que não existe a alegada independência". 411

Em que pese o argumento do poder do majoritário e da fragilidade do minoritário, entendemos estar fora do escopo e da competência da CVM a regulamentação material sobre o preço de uma oferta pública ou sobre a justiça de uma relação de troca em

entre partes não relacionadas realizadas pela companhia em momento anterior, sustentando a similitude do critério de avaliação adotado nas referidas operações com o critério de comparação por múltiplos, admitido na Lei das S.A.; (ii) Processo CVM n. RJ 2005/1945 em que a controladora e também ofertante requereu a dispensa do laudo de avaliação, estipulando o preço com base nas três últimas operações privadas realizadas com as ações da companhia; e (iii) Processo CVM n. RJ 2003/12825, rel. Dir. Norma Jonssen Parente, j. 21.01.2004, em que a autarquia concedeu o pedido de registro de oferta com a adoção de procedimento diferenciado baseado em relações entre partes independentes. A mesma dispensa tem sido deferida quando o preço justo puder ser presumido, uma vez que partes independentes (ofertante e acionistas) negociam e manifestam sua concordância com o preço apresentado, como ficou determinado no Processo CVM n. RJ 2007/3296, rel. Dir. Maria Helena Santana, j. 31.10.2007, segundo o qual "[a] CVM decidiu inúmeras vezes que a negociação entre partes independentes deve ser aceita como indicadora de preço justo, e chegou até a autorizar a dispensa de apresentação de laudo de avaliação com base nessas negociações". Esse critério foi também escolhido pela Instrução CVM n. 361, de 5 de março 2002, como relevante indicador da existência de um valor comutativo. De acordo com referida instrução, o ofertante deve declarar, no instrumento de oferta, o "preço por ação da companhia objeto em negociações privadas relevantes, entre partes independentes, envolvendo o ofertante, o acionista controlador ou pessoas a eles vinculadas, realizadas nos últimos 12 meses".

Cf. PAS CVM n. RJ 2009/8316, em que a CVM expressamente afirmou que "[a] CVM tem reiterado em suas decisões que um processo de negociação independente tende a tornar comutativa a operação e a demonstrar o cumprimento dos deveres fiduciários dos administradores previstos em lei". No mesmo processo administrativo, a autarquia reconhece a coleta de intenções de investimento de investidores institucionais (que não sejam partes relacionadas ao coordenador, à companhia ou aos controladores) conduzidas pelos bancos coordenadores de uma distribuição pública de ações (processo de bookbuilding) como uma das maneiras de averiguar a adequação do valor de emissão de novas ações e, consequentemente, cumprir os preceitos do art. 170, § 1. ${ }^{\circ}$, da Lei das S.A.

410 Cf. Processo Administrativo n. RJ 2011/3859, rel. Dir. Luciana Pires Dias, j. 08.11.2011, em que se permitiu a negociação privada de ações argumentando-se que "[d]eterminar se um valor diferente do valor de mercado é adequado para selar determinada operação é sempre uma tarefa complexa, porque leva em conta inúmeros aspectos muito difíceis de serem analisados sob o ponto de vista do regulador. Por isso, entendo que primeiro é importante verificar se as condições em que tal valor foi negociado pelos administradores da companhia e aprovado por seus órgãos, de alguma maneira, levantam qualquer dúvida sobre sua adequação. Não há nada nos autos que possa demonstrar qualquer tipo de vinculação societária prévia entre Pulsa e Minerva [partes da operação]. Assim, é correto presumir que seus administradores negociaram a Promessa e o Contrato de forma independente e o resultado desta operação foi comutativo para ambas as companhias". No mesmo sentido, vide Processo n. RJ 2009/5962, rel. Dir. Marcos Barbosa Pinto, j. 23.06.2009.

411 Cf. Processo CVM n. RJ 2002/1759, rel. SER, j. 18.06.2012. 
operações de incorporação. Quanto ao primeiro caso, a então presidente da CVM Maria Helena Santana, uniformizando o entendimento da autarquia, manifestou-se afirmando que “não cabe à CVM declarar o preço justo das ações, função reservada primordialmente ao avaliador e passível de revisão por parte dos acionistas minoritários [...], além do próprio ofertante". ${ }^{412}$ Em relação às operações de incorporação, a autarquia também já se manifestou dizendo que não arbitrará uma relação de troca justa, uma vez que essa análise deve ser feita pelos acionistas e não pelo órgão regulador, o qual não teria competência legal para determinar qual deva ser a relação de troca que assegura aos acionistas o tratamento justo, cabendo às partes que se sentirem prejudicadas procurar obter, em juízo, inclusive por meio de laudos periciais, a exata definição da relação de substituição de ações que possa preservar o tratamento equitativo. ${ }^{413}$

Assim, em vez de arbitrar e analisar a justiça do preço de uma operação, a estratégia de regulação da CVM vem se consolidando na garantia de um processo de negociação que simule a relação entre partes independentes, livre de conflitos de interesses e com garantia de ampla informação aos acionistas como formas de se chegar a um valor entendido como justo. Nas palavras do então Diretor Marcos Pinto, "a CVM vem adotando uma outra estratégia, de caráter eminentemente procedimental. Ao invés de determinar o preço justo, nossas normas e precedentes têm criado procedimentos que permitem ao acionista tomar uma decisão livre e informada". ${ }^{414-415}$

412 Vide Processo CVM n. RJ 2007/3296, rel. Dir. Maria Helena Santana, j. 31.10.2007.

413 Cf. Processo CVM n. RJ 2003/12770, rel. SEP, j. 26.12.2003.

414 Cf. Processo CVM n. RJ 2007/3296, rel. Dir. Maria Helena Santana, j. 31.10.2007. No mesmo sentido, conforme resumiu o Presidente Marcelo Trindade no Processo CVM n. RJ 2007.1996, rel. Dir. Maria Helena Santana, j. 21.03.2007: “[...] assim é mesmo nos casos de ofertas para cancelamento de registro, em que a lei expressamente fala em preço justo, e a CVM, através da Instrução 361/02, determinou que essa declaração de justiça fosse feita por avaliador independente. Isto é: mesmo quando a lei fala em preço justo, o que não é o caso das ofertas de alienação controle, a CVM não examina nem muito menos declara a justiça do preço, mas apenas verifica se as formalidades e a justificação necessárias foram cumpridas".

415 Não é muito diferente o que ocorre no direito norte-americano. Inicialmente, durante a discussão legislativa que culminou na edição da Rule $13 e-3$ que regula as going private transactions, intencionava-se que a lei exigisse que tais operações fossem procedimental e substancialmente justas para os acionistas minoritários. Essa exigência foi duramente criticada sob a alegação de que extravasava da competência da SEC e, quando finalmente foi editada, foi retirada da redação final da norma. A regra atual regula as going private transactions basicamente pelas obrigações de divulgação e pela proibição de declarações falsas ou de omissões relativas a operações compreendidas pela Rule 13e3 , exigindo, entre outras coisas, que o emissor divulgue se acredita que a oferta é justa ou injusta para os minoritários. Nos moldes atuais, portanto, depois de protocolados os documentos da oferta, cabe à SEC analisá-los e comentá-los, sendo que ela pode, e geralmente exige, modificações a respeito de tais 
No mesmo sentido, avaliando as operações de incorporação, o voto de Pedro Oliva Marcilio de Sousa defende a liberdade de contratar "desde que o processo de negociação tenha sido justo e desinteressado". 416

Finalmente, comentando a importância de garantir a ampla informação aos acionistas, a CVM já se pronunciou declarando que

[a]s operações de reorganização societárias não são simples e daí por que tanto o legislador quanto o regulador têm recorrentemente procurado aperfeiçoar as regras específicas e, como as razões que podem recomendar uma reorganização societária são inúmeras e decorrem no mais das vezes de juízos discricionários de conveniência e oportunidade dos administradores e controladores, que não devem ser substituídos pelo juízo do legislador ou do regulador, razão pela qual o tratamento normativo tem se concentrado cada vez mais na parte informacional, na já cediça linha da proteção pela informação. ${ }^{417}$

Vê-se, assim, que, embora seja bastante difícil definir um valor intrinsecamente justo para as operações de incorporação, a garantia de um processo de negociação que simule uma transação independente tem sido utilizada como alternativa para assegurar a justiça das operações. Essa estratégia, inclusive, foi seguida na edição do PO CVM 35 que estudaremos no item 3.2.3 abaixo.

\subsubsection{Tratamento Equitativo}

Outro fator frequentemente citado nas operações de incorporação que poderia impor limites à negociação da relação de substituição de ações é a necessidade de assegurar um tratamento equitativo aos acionistas das sociedades envolvidas. Sob essa perspectiva, o poder da maioria e a liberdade de contratar os termos da operação estariam

arquivamentos, notadamente quando os procedimentos usualmente utilizados para se garantir a justiça da operação não tiverem sido seguidos (cf. M. J. MCGUINNESS; T. REHBOCK, Going-Private Transactions: A Practitioner's Guide, 30 Del. J. Corp. L. 437, 2005, p. 15).

416 Cf. Processo CVM n. RJ 2007/4933, rel. SEP, j. 19.06.2007. No mesmo sentido, vide Processo CVM n. RJ 2007/13175, rel. SEP, j. 12.11.2007 em que se diz que "a característica fundamental que deve estar presente na determinação da relação de substituição é que o processo ocorra de maneira justa e desinteressada"; e D. KALANSKY, Incorporação de ações... cit., p. 54.

417 PAS CVM n. 10/00, rel. Dir. Luiz Antonio de Sampaio Campos, j. 08.07.2004. 
equilibrados tanto pela necessidade de justificar as condições negociadas como pela obrigatoriedade de assegurar aos acionistas um tratamento equitativo. ${ }^{418-419}$

No campo das operações de incorporação, a referência feita a um genérico tratamento equitativo é bastante confusa, sendo tal termo utilizado sem muito rigor técnico e precisão. Em uma primeira acepção, a referência ao tratamento equitativo é feita para designar uma relação de troca equitativa entre os acionistas da incorporadora e os acionistas da incorporada (ou aqueles que têm suas ações incorporadas), referindo-se a uma possível justiça nessa relação entre incorporadora e incorporada. ${ }^{420}$ Já em outras tantas hipóteses, menciona-se a necessidade de se assegurar um tratamento equitativo entre os acionistas de uma mesma sociedade como condição de validade das operações de incorporação, sendo que, nesse caso, o termo é utilizado no sentido de se buscar um tratamento igualitário entre tais acionistas. ${ }^{421-422}$

Quanto à primeira acepção de equidade, a qual se aproxima da ideia de justiça da operação, remetemos aos nossos comentários feitos no item anterior quando exploramos a noção de valor justo em operações de incorporação. A nosso entender, o uso do termo "equitativo" com essa acepção não agrega mais segurança do que defender um valor justo para as operações de incorporação e, como vimos acima, tais expressões têm utilização limitada como parâmetro definidor da relação de troca de ações.

418 Vide J. A. ENGRÁCIA ANTUNES que entende que o "princípio jurídico-societário da igualdade de tratamento de sócios constitui um limite imanente imperativo à autonomia privada no exercício do poder majoritário no âmbito das sociedades" ( $O$ artigo 490 do CSC e a Lei Fundamental - "Propriedade corporativa”, propriedade privada e igualdade de tratamento, Estudos em comemoração dos cinco anos (1995-2000) da Faculdade de Direito da Universidade do Porto, Coimbra: Coimbra Ed., 2001, p. 263. Vide também H. WIEDEMANN, Gesellschaftsrecht: ein Lehrbuch des Unternehmens- und Verbandsrechts, v. I, München: Beck, 1980, p. 428-429; e L. A. Bianchi, Il Giudizio di “Congruità”... cit., p. 194.

419 A análise proposta nesse item é relevante não só porque o tratamento equitativo poderia ser fator limitador da instituição da relação de troca, mas também porque poderia ser objeto de intervenção da CVM com o intuito de barrar práticas não equitativas no mercado, nos termos do art. $4 .^{\circ}$, VII, da Lei n. 6.385, de 7 de dezembro de 1976 (cf. voto de Norma Jonssen Parente no Processo CVM n. RJ 2003/12770, rel. SEP, j. 26.12.2003).

420 Vide Processo CVM n. RJ 2007/14245, rel. SEP, j. 14.12.2007 e 17.12.2007; e Processo CVM n. RJ 2003/12770, rel. SEP, j. 26.12.2003.

421 Nesse sentido, vide voto de Luiz Leonardo Cantidiano, no Processo CVM n. RJ 2003/12770, rel. SEP, j. 26.12.2003.

422 Exemplificando a confusão nessa seara, N. J. PARENTE, em artigo publicado na Revista Capital Aberto, ora defende o tratamento equitativo entre os acionistas da incorporadora e da incorporada, usando, inclusive, a relação de troca prevista no art. 264 da Lei das S.A. como exemplo de relação de troca equitativa, ora prega a igualdade de tratamento entre os acionistas da mesma sociedade (Maioria não basta... cit., p. 52). 
Necessário, então, analisarmos o tratamento equitativo no seu segundo significado, i.e., aquele que supostamente se refere aos acionistas de uma mesma sociedade, exigindo a igualdade ou paridade de tratamento entre eles, bem como explorarmos a extensão da aplicabilidade desse conceito às operações de incorporação com o intuito de apurar se esse critério poderia, de fato, limitar a negociação da relação de substituição de ações.

Pois bem. A primeira dificuldade que se enfrenta na tentativa de se precisar o conteúdo do que seria o tratamento equitativo ou igualitário entre os sócios é o fato de que a Lei das S.A. não chegou a positivar expressamente um princípio de tratamento equitativo no direito societário, de modo que seu significado não decorre da leitura imediata da lei. Ao mesmo tempo, existe uma concepção de tratamento equitativo que permeia o pensamento dos juristas, do mercado e dos investidores como um pressuposto básico que rege todas as companhias, qual seja, o de que todas as ações de uma mesma classe devem ser tratadas como títulos que detêm direitos homogêneos sobre a empresa, de forma que cada ação represente os mesmos direitos sobre os ativos da companhia e, portanto, em cada distribuição de ativos ou alteração na participação dos acionistas na sociedade, cada acionista receba montantes equivalentes ou participe de maneira igualitária em função de suas ações com os demais acionistas. ${ }^{423}$ Nesse sentido, lecionam A. LAMY FILHO e J. L. BULHÕES PEDREIRA que,

embora a igualdade entre os acionistas seja princípio geral das companhias, a lei admite que uma ou mais classes de ações preferenciais tenham prioridades ou vantagens e o art. 16 admite, na companhia fechada, diversas classes de ações [...]. O acionista tem direito de exigir de parte da companhia e dos demais acionistas tratamento consentâneo com essa igualdade. ${ }^{424}$

No mesmo sentido, J. X. CARVALHO DE MENDONÇA reconhece como um dos direitos individuais do acionista o direito de ser tratado no mesmo pé de igualdade de todos

\footnotetext{
423 Cf. V. BRUDNEY, Equal Treatment of Shareholders... cit., p. 1074.

424 Direito das companhias, v. 2, cit., p. 1765.
} 
os outros acionistas, de modo que ele poderia se opor a todos os atos e deliberações da assembleia que ofendam a esse princípio. ${ }^{425}$

Além disso, uma porção de normas na nossa Lei das S.A. parece se inspirar na ideia de tratamento igualitário entre os sócios, bem como alguns artigos chegam a utilizar expressamente o termo "equitativo", ainda que sem definir precisamente o conteúdo de tal termo. $^{426}$

Exemplificativamente, o termo "equitativo" é mencionado no art. 117, § 1. , (f), quando se define como hipótese de abuso de poder de controle contratar com a companhia em condições de favorecimento ou não equitativas, e no art. 156, § 1. ${ }^{\circ}$, quando se proíbe que o administrador contrate com a companhia em condições não razoáveis ou equitativas. Nesses artigos, o termo equitativo parece ser utilizado para assegurar relações equilibradas entre as partes como se ambas estivessem em pé de igualdade para contratar, simulando operações que poderiam ser encontradas no mercado entre partes independentes se uma pessoa (sem nenhum conflito de interesses) tivesse tomado a mesma decisão. ${ }^{427}$ Também no antigo $\S 1 .^{\circ}$ do art. 255 da Lei das S.A., revogado pela Lei n. 9.457/1997, havia previsão de que fosse assegurado tratamento equitativo aos acionistas minoritários na alienação do controle de companhia aberta dependente de autorização do governo para funcionar. $^{428}$ Nesse caso, o tratamento equitativo foi entendido como sinônimo de

425 Tratado de direito comercial brasileiro, v. III, 4. ed., Rio de Janeiro/São Paulo: Freitas Bastos, 1963, p. 458.

426 O mesmo acontece em outras legislações. No direito italiano, por exemplo, G. D'ATTORRE afirma que "[n]ell'ordinamento delle società per azioni nessuna norma impone in termini generali di garantire la parità di trattamento tra i soci nella esecuzione o modificazioni del contratto sociale, ma, allo stesso tempo, una pluralitá di norme sembrano ispirarsi più o meno direttamente al detto principio" (Il Principio di Egualianza tra Soci nelle Società per Azioni, Milano: Giuffrè, 2007, p. 201). Ainda, L. A. BIANCHI complementa dizendo que o princípio do tatamento equitativo "pur non essendo stato formalmente codificato dal nostro legislatore, deve ritenersi, nondimeno, vigente nell'ordenamento italiano" (Il Giudizio di "Congruità"... cit., p. 194). No direito alemão, antes mesma da positivação do princípio da igualdade de tratamento no §53a da Aktiengesetz, a doutrina e a jurisprudência o tinham como direito não escrito (vide M. V. VON ADAMEK, Abuso de minoria em direito societário (abuso das posições subjetivas minoritárias), tese de doutorado apresentada à Faculdade de Direito da Universidade de São Paulo, 2010, p. 88).

427 N. EIZIRIK, A Lei das S/A comentada, v. II, São Paulo: Quartier Latin: 2011, p. 690.

428 Lei das S.A.: "Art. 255. A alienação do controle de companhia aberta que dependa de autorização do governo para funcionar está sujeita à prévia autorização do órgão competente para aprovar a alteração do seu estatuto. $\S 1 .^{\circ}$ A autoridade competente para autorizar a alienação deve zelar para que seja assegurado tratamento equitativo aos acionistas minoritários, mediante simultânea oferta pública para a aquisição das suas ações, ou o rateio, por todos os acionistas, dos intangíveis da companhia, inclusive autorização para funcionar". 
tratamento igualitário entre os acionistas nos mesmos termos do que previa a antiga redação do art. 254 da Lei das S.A. ${ }^{429}$ Também no contexto das ofertas públicas, a regulação tem como objetivo assegurar o tratamento equitativo entre os acionistas nos termos do art. 4. ${ }^{\circ}$ da Instrução CVM n. 361/2002, entendendo-se nesses casos o tratamento igualitário entre os acionistas da mesma espécie e classe de ação.

Em outras passagens da nossa legislação, embora não haja menção expressa, pode-se ver uma noção de tratamento equitativo que permeia certas normas do ordenamento societário, tal como a regra do $\S 1 .^{\circ}$ do art. 109 da Lei das S.A. que determina que as ações de cada classe confiram iguais direitos aos seus titulares. Embora sob uma primeira análise esse artigo pareça conferir um tratamento equitativo entre os sócios, na verdade, o que se estabelece é um princípio de igualdade das ações, nada dizendo, no entanto, a respeito da paridade de tratamento entre os acionistas. Sua função igualitária se assenta, a princípio, sobre o plano dos direitos das ações, sem entrar no mérito da diferenciação do tratamento conferido aos acionistas, de modo que tal artigo dificilmente poderia ser erigido a fundamento teórico da garantia de tratamento equitativo entre todos os acionistas. ${ }^{430}$

Outras disposições da Lei das S.A. parecem também se inspirar em um tratamento igualitário entre os sócios, como aquelas que asseguram (i) o direito de preferência aos acionistas no aumento de capital, bem como a manutenção da respectiva proporção entre as ações de diversas classes (prevendo, inclusive, quórum qualificado nos

429 Vide E. LACERDA TeIXEIRA; J. A. TAVARES GUerReIRo, Das sociedades anônimas... cit., p. 748. No mesmo sentido, F. MARTINS, Comentários à Lei das Sociedades Anônimas, v. 3, Rio de Janeiro: Forense, 1978, p. 348-349. Diferentemente, entendem A. LAMY FILHO e J. L. BULHÕES PEDREIRA para quem o tratamento equitativo não significa o mesmo que tratamento igualitário, desde que fosse reconhecida a participação de todos os acionistas no valor dos intangíveis da companhia (A Lei das S.A. - Parte III-Pareceres... cit., p. 670-672).

430 A mesma conclusão é exposta por G. D’ATTORRE sob o direito italiano ao comentar o art. 2348 do Codice Civile (Il Principio di Egualianza... cit., p. 201); C. ANGELICI, Parità di Trattamento degli Azionisti, Rivista del Diritto Commercialli e del Diritto Generale delle Obbligazioni, 1987, I, p. 2; e F. D’ALESSANDRO, La Seconda Diretiva e la parità di tratamento degli azionisti, Rivista delle Società, 1987, I, p. 3. Veremos, ainda assim, que esse artigo é mencionado por muitos juristas como base para defender o tratamento igualitário entre os acionistas da mesma classe de ações quando discutirmos a possibilidade de relações de troca diferenciada para ações da mesma classe no item 3.4.2 deste trabalho. Diferentemente estabelece a lei acionária alemã, que expressamente prevê o tratamento igualitário entre os acionistas dizendo que "acionistas sob pressupostos idênticos devem ser tratados da mesma forma" (cf “Aktiengesetz §53a. Gleichbehandlung der Aktionäre. Aktionäre sind unter gleichen Voraussetzungen gleich zu behandeln.”). 
termos do art. 136, I, da Lei das S.A.); (ii) a distribuição proporcional de ações no aumento de capital feito com lucros ou reservas no caso de serem emitidas ações (art. 169 da Lei das S.A.); (iii) o rateio proporcional das frações de ações que não puderem ser atribuídas por inteiros aos acionistas (art. 169, § 3..$^{\circ}$, da Lei das S.A.) ou das sobras de valores mobiliários não subscritos (art. 171, $\S 7 .^{\circ}, d$, da Lei das S.A.); (iv) o direito de preferência proporcional para adquirir ações de sociedade subsidiária integral (nos termos do art. 252 da Lei das S.A.); (v) mecanismos de resgate por sorteio (nos termos do art. 44, § 4. ${ }^{\circ}$, da Lei das S.A.) ou de modo proporcional como vem sendo admitindo pela CVM; (vi) partilha de ativos proporcionalmente entre os sócios titulares de ações da mesma espécie e classe nos casos de liquidação da sociedade (arts. 109, II, e 210, IV, da Lei das S.A.).

Não há dúvida de que todas essas normas têm o intuito de garantir a paridade entre os sócios assegurando certa intangibilidade das suas posições de sócios e uma estabilidade do peso de sua participação dentro da organização empresarial. De outra perspectiva, tais normas se traduzem ainda na obrigatoriedade de os órgãos sociais tratarem os sócios de modo igualitário, na proporção de suas respectivas participações sociais. $^{431}$

Há na lei, no entanto, hipóteses em que o tratamento equitativo dos sócios é deixado de lado e permite-se que sejam criadas situações em que há diferenciação entre os acionistas ou, ainda, em que os acionistas não vejam assegurada a qualquer custo a manutenção da sua participação dentro das sociedades. Como exemplos, citamos a própria permissão de criação de ações preferenciais com diferentes direitos e vantagens (inclusive podendo ser criadas ações que tenham preferência na liquidação da companhia), ${ }^{432}$ concessão de opções de compra de ações a administradores que excluem o direito de preferência dos

431 Vide também nesse sentido G. D’ATtorre, Il Principio di Egualianza... cit., p. 211. Na verdade, o tratamento equitativo entre os sócios pode se manifestar de diversas maneiras no seio das sociedades: algumas vezes, a paridade de tratamento se manifesta como um direito dos sócios de serem tratados como contraparte da sociedade em medida rigorosamente proporcional às suas participações; em outros casos, expressa-se como a proibição de que haja discriminação entre os sócios na exigência do cumprimento de suas obrigações conexas com sua participação social; outras vezes, ainda, traduz-se como o direito paritário dos sócios de se beneficiarem das consequências do aumento de capital ou, ainda, como a vedação de que haja modificação nas participações societárias dos sócios em virtude de atos praticados pelos administradores como resultados da atividade empresarial (idem, p. 257).

432 De acordo com G. D'ATTORRE, a possibilidade de se criar ações preferenciais mediante alterações estatutárias promovidas pela maioria mal se concilia com um eventual direito dos sócios de manter inalterada sua participação original no contrato social (Il Principio di Egualianza... cit., p. 232). 
acionistas, a possibilidade de haver cisão desproporcional de sociedades, ${ }^{433}$ possibilidade de limitação do exercício do direito de voto de determinados acionistas, a admissibilidade de preços de emissão diferentes para ações preferenciais e ordinárias nos aumentos de capital como já admitido pela CVM ou, ainda, a possibilidade de que ações ordinárias e preferencias sejam adquiridas por "preços justos" diferentes em operações de fechamento de capital. Em muitos casos, as normas em questão são fundamentais para permitir e resolver o contraste existente entre o interesse da sociedade de modificar sua própria organização em contraposição ao interesse dos sócios em manter inalterada sua participação social como originalmente constava no contrato social original. No exemplo das legislações europeias, mesmo no caso das operações de fusão e incorporação, podem-se verificar situações em que o princípio do tratamento igualitário não é respeitado como é o caso, por exemplo, da permissão da atribuição de montante em dinheiro a alguns sócios, permitindo que haja certa modificação nas posições recíprocas dos sócios já que alguns deles são excluídos em todo ou em parte da sociedade resultante ao final da operação. ${ }^{434}$

No mesmo sentido, a Suprema Corte de Delaware também já decidiu que o tratamento paritário dos sócios pode ser suspenso quando o benefício (welfare) de todos os acionistas assim o exigir. ${ }^{435}$ No caso Unocal Corp. v. Mesa Petroleum, ${ }^{436}$ a corte entendeu ser possível discriminar entre os acionistas da mesma classe quando o conselho de administração da companhia agir para proteger a companhia e os acionistas de um dano razoavelmente percebido pela administração, o que demonstra que o paradigma do tratamento igualitário dos acionistas de uma mesma classe também não é absoluto nessa legislação. ${ }^{437}$

433 É verdade que a cisão desproporcional requer o consentimento de todos os sócios, inclusive daqueles sem direito a voto, nos termos do art. $229, \$ 5 .^{\circ}$, da Lei das S.A. Ainda assim, fica claro que o tratamento paritário entre os sócios não é regra absoluta e inderrogável nos termos da nossa Lei das S.A. Em outras legislações, como a italiana, a derrogação do princípio do tratamento equitativo e da obrigatoriedade de manutenção da participação dos sócios é ainda mais forte, pois é possível que a cisão desproporcional seja aprovada por maioria desde que se assegure aos demais sócios o direito de ter suas ações adquiridas. O direito à manutenção da participação foi trocado, portanto, por uma compensação monetária (vide G. D’ATTORRE, Il Principio di Egualianza... cit., p. 248-249).

434 Cf. N. ROBIGLIO apud A. VICARI, Gli Azionisti... cit., p. 47.

435 Cf. J. Robert Brown Jr., Discrimination, Managerial Discretion and the Corporate Contract, 26 Wake Forest L. Review, 1991, p. 541-542.

436 Co. 493 A.2d946 (Del. 1985).

437 O precedente foi depois seguido no caso In re Times Mirror Shareholder Litigation, 1994 WL 1753203 (Del. Ch., Nov. 30, 1994): "Is it permissible to treat one set of shareholders holding a similar security differently from another subset of that same class? For a long time I think it might have been said that it was not permissible. And I don't need to state a final opinion on a case that is at the settlement stage but 
Como se vê, não apenas não existe uma norma geral que estabeleça o dever de respeitar em qualquer caso a paridade de tratamento entre os sócios, como também o tratamento paritário dos sócios, ao mesmo tempo que permeia muitas normas do nosso sistema, é tantas outras vezes deixado de lado para se permitir situações em que os acionistas sofrem certa diferenciação. ${ }^{438}$ Não parece ter razão, portanto, a tese que advoga a imperatividade absoluta do princípio do tratamento equitativo e entende ser inválida qualquer deliberação que implique certa disparidade entre os acionistas. ${ }^{439}$ Ao contrário, é necessário avaliar os casos decididamente relevantes e significativos na prática societária para que se permita a derrogação de tal princípio entre os sócios, pois é preferível um regime legal que permita a disparidade caso ela seja necessária para atingir um interesse digno de tutela que, de outra feita, seria sacrificado ou ignorado sob a disciplina estritamente paritária. ${ }^{440}$ Nesse sentido, BERLE e MEANS, discorrendo sobre os poderes do controlador em alterar os direitos dos acionistas originalmente constantes no contrato social, já defendiam a validade de modificações nas posições relativas dos sócios em relação ao capital social, desde que tais alterações sejam realizadas para atender aos interesses da companhia e não sejam injustas para os acionistas. ${ }^{441}$

Nessa linha de pensamento, G. D'ATTORRE entende que a extensão e o grau de imperatividade do tratamento equitativo dos sócios variam em função da vontade social ou, em outras palavras, do interesse social perseguido pela sociedade. Em alguns casos, portanto, seria admissível suprimir o direito dos sócios de manter intacta sua participação proporcional no capital social quando essa manutenção representar obstáculo para se

just assess the strengths and weaknesses of the claims. But in doing that, I have to say that I am inclined to think that it is permissible. The Unocal precedent was cited, and I think it would be a relevant case were one to have to address this question finally".

438 Nesse sentido, a própria irredutibilidade do princípio do tratamento equitativo a uma matriz unitária que traga a solução para os possíveis conflitos de tais normas evidencia a impossibilidade de se afirmar a existência de um princípio do tratamento paritário dos sócios de caráter geral e unívoco (G. D’ATTORRE, Il Principio di Egualianza... cit., p. 255 e 258).

439 Nesse sentido, vide G. OPPO, Eguaglianza e contratto nelle società per azioni, Rivista di Diritto Civile, 1974, I, p. 629 ss.

440 N. ROBIGLIO apud A. VICARI, Gli Azionisti... cit., p. 47-48. Por essa mesma razão, o autor entende ser "preferibile qualificare la parità di tratamento da un punto di vista di teoria generale como un 'principio' piuttosto che come una norma positiva (rule). [...] I principi infatti si comportano in modo del tutto differente dalle norme. Queste operano in maneira esclusiva e non ammettono eccezioni, le quale si configurano piuttosto come violazioni... Ai principi sono propri altri caratteri: essi non operano automaticamente, piutosto 'spingono in una direzione' e hanno una dimensione che le norme non hanno: quella del peso e dell'importanza”.

441 The Modern Corporation and Private Property, New York: Macmillan, 1933, p. 207-220. 
alcançar o interesse social. Nesse sentido, a exigência de se garantir um tratamento paritário entre os sócios poderia ser revista nas diversas operações societárias em função da maior ou menor instrumentalidade que tal princípio tenha no exercício da atividade social e da própria empresa. ${ }^{42}$ Assim, quando os objetivos do negócio e da empresa exigirem que o tratamento paritário dos sócios seja excluído ou limitado, esse último deverá ser redimensionado ou posto de lado de forma a deixar que a liberdade negocial da empresa seja amplamente desenvolvida. Dessa maneira, para as operações societárias que sejam meios para realização dos objetivos da empresa, a paridade de tratamento dos sócios, em todas as suas várias nuances, cede lugar para a plena liberdade negocial que caracteriza a atividade empresarial. ${ }^{443}$

Em relação a essas operações, no entanto, continua o autor afirmando que não se pode conceber a existência de uma licença plena para se promover a discriminação entre os sócios minoritários em favor dos sócios majoritários, concedendo a esses ampla liberdade de extrair benefícios privados de controle decorrentes de sua posição dentro da sociedade. Mesmo nos casos em que os acionistas não possam reivindicar um direito a paridade de tratamento, a sua posição deve ser tutelada de outras maneiras. ${ }^{444}$

Um primeiro limite à liberdade dos órgãos de administração de promover a discriminação entre os sócios é, obviamente, o interesse social a ser perseguido, o qual impede a adoção de atos que possam resultar em prejuízo aos sócios. Se a instrumentalidade da operação para alcançar os objetivos do negócio possibilita, de um

442 O autor menciona como exemplo a possibilidade existente sob a lei italiana de excluir o direito de preferência nos aumentos de capital quando o interesse social assim o exigir afirmando que "[n]ella comparazione tra l'interesse dei soci a mantenere inalterata la propria partecipazione sociale e l'interesse della società a conseguire um determinato bene in natura, il legislatore attribuisce prevalenza al secondo, sacrificando l'interesse dei soci" (Il Principio di Egualianza... cit., p. 222). Apresenta ainda o autor a distinção entre atos estáticos ou dinâmicos na vida da sociedade. Os atos estáticos seriam aqueles que não são diretamente necessários ou instrumentais para dar cumprimento ao exercício da empresa, como uma distribuição de ações aos acionistas em decorrência de aumento de capital por conversão de lucros ou reservas, que representa mera alteração nas cifras contábeis das sociedades. Nesses casos de atos "estáticos", restaria excluída a possibilidade de se derrogar a igualde de todos os sócios. Nos atos dinâmicos, ou seja, aqueles necessários à consecução do objeto social e da empresa, como operações de aumento de capital com exclusão do direito de preferência (cf. possibilidade conferida pela lei italiana), o princípio do tratamento paritário entre os sócios poderia eventualmente ser derrogado para que se pudesse dar cumprimento ao exercício da atividade empresarial (idem, p. 211215).

443 Vide também a posição de J. A. ENGRÁCIA ANTUNES ao defender a possibilidade de haver discriminações que estejam baseadas no quadro legal e estatutário ou no superior interesse da própria corporação ( $O$ artigo 490 do $C S C$... cit., p. 264).

444 Cf. G. D’AtTorre, Il Principio di Egualianza... cit., p. 279. 
lado, superar a obrigatoriedade de paridade entre os sócios, de outro, marca também a fronteira da liberdade de agir da administração, a qual não pode praticar atos que estejam em desacordo com o interesse social a ser perseguido pela consecução da atividade empresarial. Assim, o abandono ao princípio do tratamento equitativo quando não houver nenhuma justificação do ponto de vista do interesse social resulta apenas em um prejuízo indevido ao valor das ações dos sócios atuais. ${ }^{445}$

Um segundo limite à possível discriminação entre os sócios é representado pela obrigação de boa-fé na execução do contrato social, a qual proíbe a prática de atos ou deliberação de medidas que sejam preordenadas a prejudicar a posição dos sócios minoritários a exclusivo benefício dos sócios majoritários. Assim, a paridade de tratamento pode ser posta de lado apenas quando o respeito a essa regra puder impedir ou dificultar a persecução do interesse social. Todavia, quando a discriminação entre todos os sócios não representar uma condição ou "preço" a ser pago para o melhor desenvolvimento da atividade empresarial, mas for fruto somente da vontade do sócio majoritário de repartir os benefícios e sacrifícios sociais em termos não proporcionais, o interesse negocial deixa de desempenhar sua função justificadora da discriminação entre os sócios e devem ser aplicados os princípios ordinários dos contratos associativos, entre eles o princípio da boafé na execução dos contratos e do tratamento igualitário entre os sócios. ${ }^{446}$ A aplicação do princípio da boa-fé na execução dos contratos, portanto, impediria uma lesão aos interesses dos sócios minoritários que não seja justificada em concreto como estritamente necessária para a perseguição do interesse social. ${ }^{447}$

445 G. D’ATtorre, Il Principio di Egualianza... cit., p. 231. No mesmo sentido, G. RIPERT e R. ROBLOT entendem que a ruptura da igualdade entre os acionistas por uma decisão majoritária dá azo a um controle judiciário se ela não é justificada pelo interesse social (Traité de Droit Commercial - Les Sociétés Commerciales, 17 ed., Paris: L.G.D.J., 1998, t. 1, p. 1125). Em sentido semelhante, C. ANGELICI, Parità di trattamento degli azionisti... cit., p. 12.

446 Não por outra razão C. ANGELICI identifica a falta de paridade entre os sócios como um dos indícios sintomáticos, embora não necessariamente único e decisivo, para a avaliação e identificação de abuso do poder de controle (Parità di trattamento degli azionisti... cit., p. 12-13). V. BRUDNEY, por sua vez, defende que "a disproportionate division is only justified if any gain, or better social use to be made of the assets, depends functionally on the controller receiving a disproportionate share (Equal Treatment of Shareholders... cit., p. 1082).

447 Exemplificativamente, o autor defende que só poderia haver exclusão do direito de preferência do sócio, por exemplo, quando este for absolutamente necessário para a realização do interesse social (vide G. D’ATTORRE, Il Principio di Egualianza... cit., p. 225; e também G. FERRI, Le Società... cit., p. 932). 
Por fim, um último limite imposto à liberdade dos órgãos societários de promover a discriminação entre os sócios é a proibição de realizar operações que impliquem diretamente um prejuízo patrimonial aos sócios envolvidos. Isto é, no campo das operações societárias, os órgãos sociais não são obrigados a respeitar a paridade de tratamento dos sócios, mas, em qualquer caso, não podem prejudicar o valor econômico da participação detida por cada um. ${ }^{448}$

Sob esse enfoque, passando a analisar o tratamento equitativo no contexto das operações de incorporação, a permissão de discriminação entre os acionistas, pelo menos de uma mesma classe, não parece se justificar, pois dificilmente se conseguiria comprovar a necessidade de um tratamento não equitativo entre tais acionistas como condição para se alcançar os ganhos decorrentes das operações de incorporação. Como se sabe, os ganhos advindos de tais operações resultam das sinergias entre as companhias derivadas das possíveis economias ou dos benefícios que a operação possibilita alcançar. Essas sinergias, no entanto, estão implícitas nas duas sociedades envolvidas e em nada dependem de uma atuação diferenciada por parte de qualquer acionista que devesse receber um tratamento diferenciado. ${ }^{449}$

Nesse ponto, seria possível levantar a hipótese de que determinadas operações, ainda que benéficas a todos os acionistas, só seriam concluídas se fosse assegurado ao acionista controlador um tratamento mais benéfico em relação aos demais acionistas. Nesses casos, se a reivindicação do controlador para receber esse "incentivo" se basear apenas no seu poder de extrair da minoria um "pedágio" para que dê seu consentimento para a realização de determinada operação e não em relação a uma reivindicação legítima de maior compensação financeira por suportar maiores riscos, parece haver pouca justificativa para atender a essa reivindicação. Para sacrificar o tratamento equitativo nesses casos, seria sempre necessário questionar se tais ganhos são realmente significativos

448 Vide G. D’AtTorre, Il Principio di Egualianza... cit., p. 279-284. O autor adota, portanto, o critério paretiano de eficiência para avaliação das operações, segundo o qual são válidas somente as alterações que levem alguém a estar em uma posição superior sem que nenhuma outra pessoa passe a estar em situação inferior. Não seriam compatíveis com o ordenamento, portanto, as posições interpretativas mais radicais que seguem a linha de eficiência de Kaldor-Hicks, as quais reconhecem a legitimidade de operações que implicam um aumento da riqueza global, ainda que causem prejuízo à situação patrimonial de um ou mais sócios.

449 Cf. V. BRUDNEY, Equal Treatment of Shareholders... cit., p. 1100-1101. 
e se efetivamente dependem da não aplicação de uma regra de tratamento equitativo. ${ }^{450}$ Caso contrário, estaria se faltando com o cumprimento do dever de boa-fé do acionista controlador em aprovar a operação e incorrendo-se em abuso de poder pela maioria que propõe e aprova uma relação de troca que fere o princípio da paridade entre os acionistas. $^{451}$

A vedação a um tratamento não equitativo conforme exposto acima está em linha também com o pensamento de A. PEREZ TROYA, que identificou na relação de troca duas ordens diferentes da paridade entre os sócios nas operações de incorporação: a primeira delas diz respeito à distribuição do capital entre os sócios das duas sociedades envolvidas consideradas de modo global, o que a autora batizou de relação de troca "externa"; a segunda diz respeito à distribuição das parcelas recebidas por cada sociedade entre seus respectivos acionistas, denominada relação "interna". ${ }^{452}$

Sob a óptica interna, corroborando o que foi dito acima, parece não haver dúvidas para a autora de que existe obrigatoriedade de todos os acionistas de uma mesma classe serem tratados igualmente, sendo que todos devem ser diluídos na proporção das antigas participações que detinham, pois a igualdade entre os acionistas é princípio geral do direito societário que admite distinção apenas em função da criação de uma ou mais classes de ações preferenciais ou, nas companhias fechadas, também de ações ordinárias. É bem verdade que a legislação espanhola não deixa dúvidas sobre a obrigatoriedade do tratamento paritário dos sócios nas operações de incorporação, pois prevê expressamente no art. 24-1 da Ley 3/2009 que "os sócios das sociedades extintas se integrarão na sociedade resultante da fusão, recebendo um número de ações ou participações, ou uma quota, na proporção da sua respectiva participação naquelas sociedades”. No entanto, para a autora, a previsão legal é até desnecessária, pois essa exigência de trato paritário entre os sócios decorre do postulado geral de que "às mesmas ações, os mesmos direitos", paradigma elementar do direito societário e observado por outras legislações ainda que na ausência de previsão expressa como faz a lei espanhola. ${ }^{453}$ Também no direito português

\footnotetext{
$450 \quad$ Idem, ibidem, p. 1079 e 1082.

451 Cf. L. A. BIANCHI, Il Giudizio di “Congruità”... cit., p. 196.

452 A mesma divisão é proposta por G. BAUdEU; G. BELlargent, Fusion de sociétés, Fascicule 164 B... cit., p. 8.

453 Cf. A. PÉREZ TROYA, La determinación del tipo de canje... cit., p. 102, comentando o antigo art. 247.1 do Real Decreto Legislativo 1564/1989 de 22 de dezembro que aprovou o Texto Revisado da Lei de
} 
existe regra expressa exigindo, a princípio, o tratamento igualitário dos acionistas. Conforme o art. 103/2-c do Código das Sociedades Comerciais, cada um dos sócios prejudicados deverá aprovar as operações em que houver alteração na proporção das suas participações sociais em face dos restantes sócios da mesma sociedade.

Nesse mesmo sentido, a doutrina nacional já se manifestou afirmando que a divisão das ações emitidas pela companhia incorporadora entre os acionistas da sociedade incorporada ou aqueles que têm suas ações incorporadas deve respeitar a participação que cada acionista detinha no capital social da incorporada ou da sociedade cujas ações são incorporadas em conformidade com as normas de participação no acervo social, sem que seja conferido nenhum privilégio a determinados acionistas. ${ }^{454}$ Além disso, a distribuição das ações deveria ser feita respeitando-se o princípio da equidade entre todas as ações da mesma espécie e classe, i.e., assegurando que os acionistas não controladores irão ingressar no capital social da incorporadora em igualdade de condições com o controlador, desde que fossem titulares da mesma espécie e classe de ações, estando protegidos, portanto, pelo interesse do controlador em aprovar a melhor relação de troca para suas ações. ${ }^{455}$

Passando então para a análise sob a óptica externa, A. PÉREZ TROYA propõe uma interpretação de tratamento paritário diferente do sentido que se tem dado a esse termo no Brasil. Para ela, o tratamento equitativo na relação externa, i.e., a divisão do novo patrimônio entre as duas sociedades, não se traduziria em buscar uma relação de troca que seja equitativa no sentido de "justa" porque baseada em um rateio proporcional dos patrimônios envolvidos (independentemente de como tais patrimônios foram avaliados), e sim em uma vedação a um tratamento discriminatório entre os acionistas das duas

Sociedades Anônimas. Também advogando no sentido da obrigatoriedade de tratamento equitativo entre os sócios e vedação a diluições de modo desproporcional, vide J. GARRIGUES e R. URIA, que argumentam dizendo que essa proporcionalidade atende ao inescusável princípio da igualdade que impede que a fusão traga vantagens patrimoniais a um sócio em detrimento dos outros, de modo que a participação de cada acionista no capital social da sociedade resultante deve ser medida com a mesma regra e com o mesmo critério (Comentario a la Ley... cit., p. 642 e 665-666). Vide também J. SANCHEZ OLIVÁN, defendendo esse artigo da lei espanhola como a única forma de assegurar a equidade entre os acionistas nas operações de incorporação (La fusión de sociedades... cit., p. 126).

454 Cf. N. EIZIRIK, que chega a dizer que essa característica é essencial da operação de incorporação (Temas de direito societário... cit., p. 324). Vide também A. LAMY FILHO; J. L. BULHÕES PEDREIRA, A Lei das S.A. - Parte III - Pareceres... cit., p. 582; e C. M. TOMAZELlA, Proteção de acionistas e credores... cit., p. 72.

455 Cf. C. M. Tomazella, Proteção de acionistas e credores... cit., p. 71-72; e P. C. ARAGÃO; M. M. MAVIGNIER DE LIMA, Incorporação de controlada... cit., p. 346 
sociedades envolvidas. As operações de incorporação devem, portanto, ter efeitos neutros para os acionistas de modo que não resultem vantagens ou benefícios a alguns deles em detrimento dos outros. Essa exigência baseia-se no pressuposto básico de que as operações de incorporação implicam a continuidade de todas as relações que antes existiam e que se fundem na incorporadora e que a atribuição das ações da incorporadora aos novos acionistas não decorre de uma contraprestação pelo patrimônio transmitido individualmente por cada acionista - de modo que pudesse haver vantagens para uns em detrimento dos outros como se cada acionista, individualmente, negociasse sua relação de troca -, mas é uma consequência natural da incorporação.

Essa discussão, evidentemente, relaciona-se com a própria natureza jurídica da incorporação e da relação de substituição que, como vimos na linha de interpretação de D. C. GONÇALVES, C. SANTAGATA e da própria autora, está marcada por um caráter de continuidade e manutenção do status socii dos acionistas, havendo dependência entre as antigas e as novas participações recebidas à luz da vontade dos sócios de unificar o substrato pessoal e patrimonial das sociedades, mas não de transformar tais operações em um negócio jurídico de troca de participações sociais realizado por cada sócio de modo individual. Como já se discutiu nos trechos referentes aos procedimentos das operações de incorporação, embora os acionistas possam ter interesse jurídico na incorporação, não são tecnicamente uma parte nas incorporações, pois são as sociedades que realizam a operação. Assim, as novas ações seriam recebidas como uma consequência natural da incorporação em vista do novo ordenamento em que a própria sociedade decidiu se inserir, mas esse processo desenrola-se em um plano societário e não em um plano contratual que exigiria a manifestação de vontade individual dos acionistas em dispor de suas ações. ${ }^{456}$ Sob a óptica externa, portanto, o tratamento equitativo impediria que a relação de troca fosse determinada de modo que beneficiasse um acionista como se ele tivesse, individualmente, negociado melhor suas ações com a contraparte da operação.

Nesse mesmo sentido R. VENTURA explica que

se se tratasse de trocas individuais de participações, o valor destas seria determinado conforme o interesse de cada parte, como em qualquer contrato individual; poderia ser inferior ao valor real das participações,

456 Cf. L. A. BIANCHI, Il Giudizio di “Congruità”... cit., p. 169. 
em desfavor de uma outra parte, bem como poderia ser-lhe superior, beneficiando uma parte com a aquiescência da outra. [...] No caso de fusão, os sócios não intervêm no processo até lhes ser apresentado, para deliberação, o projecto de fusão. Portanto, as administrações das sociedades participantes terão de ter em conta o interesse da generalidade dos sócios quando elaboram o projecto e bem assim os sócios, quando sobre ele deliberam, agem sobre interesses que a todos são comuns. ${ }^{457}$

Em linha com o exposto acima, na teoria de D. C. GONÇALVES desenvolvida sobre os limites do statuo viae, vimos que o princípio da identidade funciona como um dos limites da instabilidade do investimento dos sócios. De acordo com esse princípio, a manutenção do status socii do acionista na nova empresa exigiria também a manutenção da mesma ratio societária, i.e., que a posição relativa do sócio diante dos demais sócios não sofra alteração. ${ }^{458}$ Assim, relações de troca que permitissem aos acionistas alterar sua posição perante os demais sócios estariam em desacordo com tal princípio e não poderiam ser admitidas. $^{459}$

Não obstante o que se expôs acima, em sentido radicalmente oposto, a literatura americana muitas vezes defende uma liberdade bastante ampla na discriminação entre os sócios sob o argumento de que o abandono dessa regra seria justificável porque, $e x$ ante, investidores minoritários racionais deveriam consentir com $\mathrm{o}$ tratamento discriminatório porque estariam em melhor posição sob um regime que garanta a eles um pedaço (ainda que modesto) dos ganhos, mesmo que a outro acionista (em geral, o controlador) caiba maior fatia desses ganhos.

Nesse sentido, F. H. EASTERBROOK e D. R. FISCHEL entendem que não há uma obrigação legal de compartilhamento de ganhos em operações societárias complexas e defendem que a riqueza esperada dos acionistas (e da sociedade em geral) é maximizada por regras que permitem alocações iníquas dos ganhos nas operações envolvendo o controle da companhia, ao mesmo tempo que a partilha compulsória e equânime dos ganhos esperados em tais operações reduz o número de operações disponíveis para as empresas. Além disso, para compensar os riscos de eventuais tratamentos não equitativos,

\footnotetext{
457 Fusão, cisão, transformação... cit., p. 77-78.

458 Idem, ibidem, p. 376.

459 No mesmo sentido, vide L. A. BIANCHI, Il Giudizio di “Congruità”... cit., p. 196.
} 
os investidores poderiam sempre diversificar seu portfólio de investimentos de modo que compensem eventuais perdas ocorridas em determinadas operações específicas. Para os autores, legislações que possibilitam distribuições não equitativas dos ganhos decorrentes das alterações no controle, desde que os demais investidores não sejam colocados em situação pior a que se encontravam antes da operação, são aquelas que geram a maximização da riqueza dos acionistas e, nesse sentido, tais operações seriam válidas já que agregariam valor a todos ou alguns acionistas, ainda que em diferentes proporções. ${ }^{460}$

Entretanto, tais argumentos, de ordem substancialmente econômica, não são absolutamente livres de críticas, pois há razões para se acreditar que a realização de tais operações, nas quais se alega a necessidade de um tratamento diferenciado, não dependeria de fato dessa discriminação para se realizarem dento de um mercado racional. Além disso, a existência de um tratamento discriminatório entre os acionistas poderia gerar custos que superariam os ganhos de eficiência que advêm dessa permissão, pois, ao perceberem o potencial de sofrerem discriminação em determinadas operações, os investidores aumentariam ex ante o custo para realizar seus investimentos. Por fim, o tratamento igualitário parece ser a expectativa e o entendimento comum do mercado, sendo improcedente o argumento de que o investidor poderia diversificar seu portfólio visto que não se pode justificar uma lesão aos seus interesses com base em um argumento de ordem econômica que impõe ao investidor a necessidade de diversificação. ${ }^{461}$

Resumindo o que se viu acima, o tratamento equitativo parece ser um princípio do direito societário que, assim como outros princípios, admite em certos casos uma diminuição na sua eficácia. A derrogação de tal princípio no contexto das operações de incorporação é bastante controversa, havendo opiniões em ambos os sentidos de modo que é difícil afirmar, a todo custo, que o tratamento equitativo deve ou não ser respeitado em operações de incorporação. A nosso ver, no entanto, dadas as características das operações

\footnotetext{
460 The Economic Structure... cit., p. 119-126.

461 Cf. V. BRUDNEY, Equal Treatment of Shareholders... cit., p. 1082. Criticando também a posição ideológica de EASTERBROOK e FISCHEL, E. F. DE PONTES afirma que essa concepção se utiliza da justificativa da não intervenção e da autorregulação, tendência que o mercado já adotou sem sucesso, devendo-se optar pela tutela legal formal e regulação explícita (Incorporação de ações no direito brasileiro... cit., p. 33). Também L. A. BEBCHUK entende que as operações de incorporação implicariam um tratamento equitativo entre os acionistas e defende que uma regra de tratamento igualitário é mais eficiente como forma de se evitar decisões distorcidas dos acionistas (Toward Undistorted Choice... cit., p. 1707).
} 
de incorporação e a natureza jurídica da relação de troca, entendemos que existe, sim, a obrigatoriedade de se respeitar o tratamento equitativo entre os mesmos acionistas pelas razões que expusemos acima, ainda que se possa argumentar - não sem contestações - a existência de um regime mais eficiente sob a perspectiva econômica. As ideias lançadas acima serão oportunamente retomadas na análise dos casos especiais de relação de troca explorados nos demais capítulos deste trabalho, particularmente em relação às questões de relações de substituição diferenciadas entre ações da mesma espécie ou de espécie diferente.

\subsubsection{Informação e Justificação Sobre os Termos da Operação}

Apesar da ampla liberdade conferida pela lei para a determinação da relação de troca das ações e para a escolha dos critérios que a fundamentam, não se pode conceber que essas definições sejam tomadas de maneira arbitrária ou injustificada. Vimos que a função da justificação, juntamente com o protocolo, é de dar informações sobre os negócios de incorporação com o intuito de possibilitar que os acionistas tenham todas as informações necessárias para deliberar se a proposta é ou não do interesse da companhia e estejam cientes da repercussão que a operação tem sobre seus direitos. ${ }^{462}$ Afinal, os acionistas não podem votar racionalmente a respeito da incorporação a menos que estejam familiarizados com seus detalhes básicos e com a justificativa exposta pela administração que elaborou o protocolo. ${ }^{463}$

Nesse contexto, um sistema informativo eficiente não apenas constrange os acionistas controladores a justificarem ex ante suas decisões, mas também possibilita, ex post, um maior controle pelos minoritários sobre os termos da operação, dificultando que tais acionistas tenham seus direitos expropriados. ${ }^{464}$ No direito brasileiro, a divulgação das informações é ainda mais fundamental porque as operações propostas não passam por

462 A Exposição de Motivos n. 196 de 24.06.1976 estabelece: “A importância das operações de incorporação, fusão e cisão na vida das sociedades, assim como a repercussão que podem ter sobre os direitos e interesses de sócios e credores, recomendam as normas, constantes dos artigos 225 e 226 , sobre o protocolo que deve ser formado pelas sociedades que participam da operação e a justificação com que esta deve ser submetida à aprovação dos sócios. O objetivo é assegurar-lhe o conhecimento de todas as condições da operação, das repercussões que terá sobre seus diretos, e do valor do reembolso que lhes caberá, caso prefiram usar do direito de retirada".

463 Cf. European Communities Commission, Report on the Draft Convention... cit., p. 51.

464 Vide nesse sentido, A. PÉREZ TROYA, La determinación del tipo de canje... cit., p. 43-44. 
nenhum juízo prévio antes de serem analisadas pelos acionistas, salvo pela eventual manifestação do conselho fiscal e dentro de suas respectivas limitações.

A garantia da eficiência dos mecanismos de tutela previstos pela legislação societária depende, portanto, de assegurar a ampla informação aos acionistas em relação aos termos das operações de incorporação. ${ }^{465}$ Além disso, a proteção do acionista por meio da ampla informação, como vimos, está em linha com a evolução do pensamento da CVM, que tem concentrado o tratamento normativo cada vez mais na parte informacional como forma de proteção aos direitos dos participantes no mercado.

Nesse campo, existem diferenças significativas entre a regulamentação brasileira e estrangeira no que tange às informações cuja divulgação é obrigatória, especialmente aquelas que podem afetar a determinação da relação de substituição de ações.

Exemplificativamente, a Diretiva 35/2011 exige que (i) sejam disponibilizados com antecedência mínima de um mês relativamente à data da assembleia geral, pelo menos, os seguintes documentos: (a) projeto de fusão; (b) as contas anuais e os relatórios de gestão dos três últimos exercícios das sociedades participantes na fusão; (c) um balanço contabilístico reportado a uma data que não deve ser anterior ao primeiro dia do terceiro mês anterior à data do projeto de fusão, no caso de as últimas contas anuais se reportarem a um exercício cujo termo é anterior em mais de seis meses a essa data; (d) quando aplicável, os relatórios dos órgãos de administração ou de direção das sociedades justificando a relação de troca; e (e) quando aplicável, os relatórios dos peritos declarando sua opinião sobre a relação de troca, informando também qualquer dificuldade na avaliação das companhias envolvidas. ${ }^{466}$ A Diretiva 2011/35 já traz, inclusive, os elementos mínimos do projeto de fusão que deverão ser divulgados, incluindo (i) o tipo, a denominação e a sede social das sociedades participantes na fusão; (ii) a relação de troca das ações e, se for o caso, a quantia em dinheiro atribuída aos acionistas; (iii) as modalidades de entrega das

465 Cf. L. S. DE ARAGÃo, Dever de informar e operações de reorganização societária, procedimento preparatório e as informações assimétricas, in: R. R. M. DE CASTRO; L. S. DE ARAGÃO, Reorganização societária, São Paulo: Quartier Latin, 2005, p. 82. Cf. P. DAVIES, nenhum mecanismo de tutela seria de fato eficiente na ausência das normas de publicidade e divulgação de informações (Introduction to Company Law, 2 ed., New York:Oxford, 2010, p. 115-116). 
ações da sociedade incorporante; e (iv) a data a partir da qual essas ações conferem o direito aos dividendos, bem como qualquer especialidade relativa a esse direito. Além disso, os órgãos de administração ou de direção de cada uma das sociedades devem informar a assembleia geral da sua sociedade e os órgãos de administração ou de direção das outras sociedades envolvidas sobre qualquer mudança importante do patrimônio ativo e passivo ocorrida entre a data da elaboração do projeto de fusão e a data da reunião das assembleias gerais em que será decidido o projeto de fusão. ${ }^{467}$ Essa exigência, como é evidente, cumpre a relevante função de divulgar aos acionistas fatos ou atos que possam interferir no patrimônio das empresas envolvidas e, portanto, alterar os termos da relação de substituição negociada que tenham ocorrido após a elaboração do projeto de fusão. É evidente, portanto, que o que se busca assegurar com tais regras de divulgação obrigatória é a possibilidade de os acionistas avaliarem e confirmarem a adequação dos métodos utilizados para determinação da relação de substituição de ações.

Por sua vez, em Delaware, exige-se que uma cópia do protocolo (merger agreement) seja enviada a todos os acionistas, inclusive àqueles que não têm direito de voto, em conjunto com a convocação para deliberar sobre a operação com antecedência mínima de 20 dias da data da deliberação. ${ }^{468}$

No Brasil, é exigido apenas que seja disponibilizado, em conjunto com o protocolo e a justificação, o laudo dos peritos onde consta a avaliação do patrimônio da sociedade ou das ações a serem incorporadas na data da veiculação do primeiro edital de convocação da assembleia que deliberará sobre a operação. ${ }^{469} \mathrm{Na}$ justificação, por sua vez, serão expostos, no mínimo, (i) os motivos ou fins da operação; (ii) o interesse da companhia na sua realização; (iii) as ações que os acionistas preferenciais receberão e as razões para a modificação dos seus direitos, se prevista; (iv) a composição, após a operação, segundo espécies e classes das ações, do capital das companhias que deverão

467 Vide art. 9. ${ }^{\circ}$ da Diretiva 2011/35.

468 Vide $\$ 251(\mathrm{c})$ do DGCL.

469 Conforme art. $135, \S 3 .^{\circ}$, da Lei das S.A. que dispõe: "§ $3 .^{\circ}$ Os documentos pertinentes à matéria a ser debatida na assembléia-geral extraordinária deverão ser postos à disposição dos acionistas, na sede da companhia, por ocasião da publicação do primeiro anúncio de convocação da assembléia-geral". Nas companhias abertas, tais documentos devem ainda ser enviados às bolsas de valores em que as ações são negociadas conforme o art. $124, \S 6 .^{\circ}$, da Lei das S.A. e as condições da incorporação devem ser publicadas como fato relevante nos termos da ICVM 319/1999. Vide também C. M. TOMAZELLA, Proteção de acionistas e credores... cit., p. 44. 
emitir ações em substituição às que se deverão extinguir; ${ }^{470} \mathrm{e}(\mathrm{v})$ o valor do reembolso das ações a que terão direito os acionistas dissidentes. No caso de companhias abertas, porém, a ICVM 319 tem exigências adicionais requerendo a divulgação de fato relevante com os termos e as condições da incorporação (art. $2^{\circ}$ ), bem como disponibilização de demais documentos que tenham sido utilizados no planejamento, na avaliação e na execução da operação de incorporação (art. 3. ${ }^{\circ}{ }^{471}$

Quanto ao balanço patrimonial utilizado como base de tais operações, a Lei das S.A. não apenas dispensa a preparação do balanço da incorporadora, como também opta por não estabelecer um intervalo máximo entre a data de tal balanço e a efetivação da operação. Desde o Decreto-lei n. 2.627/1940, o qual, diga-se, nem se referia ao balanço que serve de base à avaliação do patrimônio líquido nas operações de incorporação ou fusão, a experiência na aplicação da lei demonstrou a necessidade de se admitir expressamente que o balanço de incorporação pudesse ser levantado antes da assembleia que irá deliberar sobre a operação, uma vez que a elaboração dos balanços requer algum tempo mesmo em companhias pequenas. Atualmente, a Lei das S.A. também não estabelece prazo máximo entre a data a que se refere a avaliação e a data da deliberação da assembleia geral que aprova a operação, pois o prazo necessário para fechar o balanço varia bastante de uma empresa para outra. ${ }^{472} \mathrm{O}$ ideal, no entanto, é que o balanço que sirva de base à avaliação seja o mais recente possível, sendo admitida uma antecedência razoável tendo em vista as peculiaridades de cada sociedade. ${ }^{473}$ Até a edição da Instrução CVM n. 481, de 17 de dezembro 2009, as companhias abertas costumavam apresentar apenas os laudos de avaliação e os respectivos protocolos e justificação conforme dissemos acima. Com a edição dessa instrução, a divulgação de algumas informações adicionais tornou-se

470 Especificamente, a informação a respeito da composição do capital das companhias que deverão emitir ações em substituição às ações que serão extintas visa a facilitar os acionistas a formar seu juízo a respeito da operação, embora pudesse ser determinada apenas a partir das informações do protocolo (cf. A. LAMY FILHO; J. L. BULHÕES PEDREIRA (Coord.), Direito das companhias, v. 2, cit., p. 1760).

471 Maiores detalhes a respeito das operações de incorporação envolvendo companhias abertas serão dados no item 3.1 abaixo.

472 A defasagem entre a data do balanço que serve de base à avaliação requer que seja definido o tratamento a ser dado às mutações patrimoniais ocorridas no período, conforme disposto no inciso III do art. $224 \mathrm{da}$ Lei das S.A.

473 Cf. A. LAMY Filho; J. L. BUlhÕES PedReIRA (Coord.), Direito das companhias, v. 2, cit., p. 1777. 
obrigatória no que se refere ao direito de recesso (art. 20) e à ratificação dos peritos avaliadores (art. 21). ${ }^{474}$

A análise acima nos mostra que a legislação europeia é bem mais rigorosa do que a brasileira no que tange à quantidade e à qualidade das informações a serem divulgadas, exigindo da administração uma explicação justificada do projeto de fusão em seus aspectos jurídicos e econômicos, com especial referência à relação de troca. Da mesma maneira, os peritos independentes devem se manifestar sobre o projeto de fusão a respeito dos critérios de avaliação e se a relação de troca é justa e se se encontra devidamente justificada, bem como se os métodos para estabelecê-la foram adequados. Todas essas exigências, compreendendo um duplo regime de informação e avaliação da relação de troca que passa tanto pela administração quanto pelos peritos independentes, têm o papel fundamental de demonstrar ex ante o caráter justificado da decisão da incorporação. ${ }^{475}$ Não menos importante também é a obrigatoriedade de elaborar um balanço de incorporação com o valor de patrimônio líquido mais atualizado das sociedades, o qual, ainda que não contenha todos os ativos ou intangíveis que podem ter sido considerados para determinar a relação de troca, sem dúvida auxilia a análise pelos acionistas e credores dos termos da operação, da adequação dos métodos de avaliação utilizados e, naturalmente, da própria relação de troca. ${ }^{476}$ Além disso, esse extenso rol de informações e documentos postos à disposição dos acionistas, bem como o parecer dos peritos em relação à justiça e equidade da relação de troca, cumprem papel relevante no procedimento de incorporação em benefício dos minoritários, pois a existência de um relatório negativo emitido pelos peritos já permite apreender uma falta de justificação para a operação, o que facilitará eventuais impugnações pretendidas.

No Brasil, ao contrário do que se vê na Europa, a prática das operações de incorporação demonstra que os documentos de protocolo e justificação tratam os motivos e justificativas das operações com demasiada superficialidade, utilizando-se de bordões e palavras-chave quase sempre uniformizados como "simplificação da estrutura societária e

\footnotetext{
474 Em certos casos em que há transferência do poder de controle por meio de uma operação de incorporação ainda é possível argumentar se os requisitos do art. 19 da mesma instrução não seriam aplicáveis (cf. E. F. DE PONTES, Incorporação de ações no direito brasileiro... cit., p. 78).

475 Cf. A. PÉREZ Troya, La determinación del tipo de canje... cit., p. 39.

476 Idem, ibidem, p. 128-131.
} 
operacional", "redução de custos financeiros, logísticos, operacionais e de manutenção" e "ganhos de sinergia". No entanto, nenhuma justificação de fato demonstra de onde vêm a redução dos custos ou os ganhos de sinergia, deixando essas expressões vazias de conteúdo. ${ }^{477}$ Se uma operação é juridicamente justificável em função dos ganhos potenciais, é inegável que a administração deve demonstrar esses ganhos, inclusive, por meio de projeções fundamentadas, de forma que a justificação pode não ser suficiente se não houver demonstração cabal das razões da incorporação e da busca dos objetivos traçados para a operação, sejam eles a maximização do retorno sobre o capital investido, a redução de custos ou outros benefícios que a administração acredita obter com a operação. $^{478}$

Assim, embora não seja exigido pela Lei das S.A., entendemos que a necessidade de demonstrar cabalmente aos acionistas que as operações de incorporação atendem ao interesse social faz com que, obrigatoriamente, outros laudos de avaliação tenham que ser produzidos além daquele que avalia o patrimônio ou as ações sendo incorporadas para fins de cumprimento do art. 226 da Lei das S.A. Tais laudos por sua vez deverão comparar os patrimônios das companhias envolvidas e detalhar minuciosamente os benefícios esperados com a operação, bem como demonstrar porque as operações de incorporação são a melhor alternativa para se alcançar tais objetivos. Além disso, explicações também deveriam ser fornecidas a respeito de como tais benefícios estão sendo rateados entre as companhias, acompanhadas das respectivas razões. ${ }^{479}$

477 Cf. E. F. DE PONTES, Incorporação de ações no direito brasileiro... cit., p. 35. No mesmo sentido, R. J. GILSON e B. S. BLACK dizem que "without more, however, synergy is less a theory than a tautology; it posits the fact of value creation but offers no hint of what caused it" (The Law and Finance... cit., p. 258).

478 Cf. E. F. DE PONTES, Incorporação de ações no direito brasileiro... cit., p. 36. R. F. BRUNER cita em seu livro Mark Sirower, vice-presidente do Boston Consulting Group, ao dizer que "the easiest way to loose the acquisition game is by failing to define synergy in terms of real, measurable improvements in competitive advantage". Para isso, o autor propõe uma série de mecanismos para efetivamente mensurar as sinergias de uma operação (Applied Mergers... cit., p. 325 e ss.).

479 L. A. BIANCHI também critica nesse sentido a maneira como são elaboradas as avaliações que levam à determinação da relação de troca e os critérios por elas utilizados, os quais, em geral, consideram apenas os patrimônios das empresas de maneira separada e sem buscar o "capital econômico" das sociedades envolvidas. Salienta o autor que a utilização de critérios como o de cotação em bolsa ou patrimonial podem não ser suficientes dado que a operação não se reduz à mera troca de ações, como ocorre em um contrato de permuta, e sim a uma compenetração e unificação organizativa e societária (Il Giudizio di “Congruità"... cit., p. 90-92). 
Nesse sentido, a CVM também já se manifestou declarando que nas incorporações, em especial aquelas que envolvem companhias controladas, as funções dos laudos de avaliação são bastante relevantes, pois tais documentos servem como parâmetro para balizar a relação de troca das ações da incorporadora e da incorporada. ${ }^{480}$ Ainda, reforçando o coro daqueles que enxergam a necessidade de uma justificativa ampla aos acionistas em termos muito mais significativos do que aqueles que existem em nossa legislação, E. F. DE PONTES afirma que toda operação de incorporação deve, no mínimo, englobar duas avaliações, com a respectiva emissão de dois laudos de avaliação e não apenas o laudo de avaliação referente ao patrimônio ou às ações a serem incorporadas. ${ }^{481}$

Convém analisar, portanto, se nossa Lei das S.A. não poderia exigir mais informações sobre a determinação da relação de substituição de ações nos moldes do que faz a legislação europeia. Como inspiração, nossa lei já prevê regra mais rigorosa de divulgação de informações no art. 170, $\S 7 .^{\circ}$, da Lei das S.A., o qual exige que a proposta de aumento do capital esclareça qual o critério adotado para a fixação do preço de emissão, justificando pormenorizadamente os aspectos econômicos que determinaram a sua escolha. A CVM já teve oportunidade de analisar alguns aspectos relativos a essa regra e decidiu que (i) a mera justificativa sobre as razões econômicas para a realização do aumento de capital não supre a necessidade de justificativa pormenorizada dos aspectos econômicos que determinaram a escolha do critério para o estabelecimento do preço de emissão; ${ }^{482}$ (ii) a justificativa referente ao preço de emissão deve ser suficientemente pormenorizada para conferir ao órgão responsável pela deliberação detalhes relativos à fixação do preço de emissão que permitam a tal órgão atestar a legitimação econômica do preço; ${ }^{483}$ e (iii) o $\S$ 7..$^{\circ}$ do art. 170 se presta à dupla função de informar os acionistas e vincular os

480 Cf. Processo CVM n. RJ 2007/11573, j. 04.10.2007.

481 Incorporação de ações no direito brasileiro... cit., p. 120. Da mesma forma, vide W. BULGARELLI defendendo a necessidade de se cotejarem os patrimônios da incorporadora e da incorporada (Fusões, Incorporações... cit., p. 165-166).

482 Cf. PAS CVM n. RJ 2004/5392, rel. Dir. Pedro Oliva Marcilio de Sousa, j. 29.08.2006.

483 Nesse sentido vide voto do então Presidente Marcelo Trindade no PAS CVM n. RJ 2005/5132, rel. Dir. Pedro Oliva Marcilio de Sousa, j. 22.08.2006, que diz: "[como se vê, a norma de exposição pormenorizada foi incluída na lei exatamente para assegurar que os administradores expusessem ao órgão societário encarregado da deliberação sobre o aumento de capital os detalhes relativos à fixação do preço de emissão, tendo em vista o potencial danoso, para os antigos acionistas, da errônea fixação do preço". Da mesma maneira, diz o Processo CVM n. RJ2004/5476, rel. Dir. Marcelo Trindade, j. 01.03.2005: "[assim, a lei exige que a proposta de aumento de capital venha acompanhada dos necessários esclarecimentos, pormenorizadamente - isto é, de uma maneira muito detalhada, que permita à administração ou aos acionistas (conforme a competência para deliberar o aumento de capital) atestar a legitimação econômica do preço de emissão das ações." 
administradores à proposta, viabilizando a prestação de contas pelos administradores, bem como sua eventual responsabilização. ${ }^{484}$ Além disso, a autarquia também já decidiu que a divulgação à assembleia do laudo de avaliação utilizado para a fixação do preço de emissão das novas ações seria suficiente para cumprir a exigência de justificativa pormenorizada do critério de fixação do preço de emissão, nos casos em que o valor do laudo foi seguido pela proposta da administração, mas que a administração deve explicações adicionais quando o laudo não é seguido ou quando o preço de emissão não coincide com os valores apontados. ${ }^{485}$

Entendemos que as considerações tecidas acima servem em muito para o contexto das operações de incorporação, notadamente no que se liga à relação de troca acordada. Fazendo um paralelo, seria possível concluir que (i) a justificativa sobre as razões econômicas da incorporação não supriria a necessidade de justificativa detalhada dos aspectos econômicos que determinaram a escolha do critério para a relação de troca; (ii) a justificativa referente à relação de troca deveria ser pormenorizada para conferir à assembleia detalhes que permitam atestar a sua legitimação econômica, o que incluiria, necessariamente, a elaboração de mais de um laudo de avaliação que permitisse aos acionistas, ao menos, comparar os patrimônios das sociedades envolvidas; e (iii) tais informações cumpriram a dupla função de informar os acionistas e vincular os administradores à proposta, facilitando a prestação de contas e eventual responsabilização. Por fim, entendemos que as relações de troca deveriam ser tanto mais justificadas aos acionistas quanto mais se afastarem dos valores determinados nos laudos de avaliação. Dessa maneira, embora entendamos que não há, necessariamente, a obrigatoriedade de manutenção de um valor da participação dos acionistas como expusemos neste trabalho, é verdade que quanto mais a relação de troca se distanciar do comparativo entre os dois patrimônios, mais deveriam ser justificadas as razões para esse fato, dando aos acionistas ciência dos motivos pelos quais suas participações foram aumentadas ou reduzidas dentro

484 “[a] disposição do § 7. o do art. 170 da lei não é apenas de caráter informacional. Ela contém, também, um elemento relevante de prestação de contas e responsabilização (accountability e liability), destinando-se reforçar o comprometimento dos administradores com os critérios escolhidos e propostos à assembleia, bem como sua eventual responsabilização no caso de falha em seus deveres de diligência e probidade" (cf. Processo CVM n. RJ 2004/5476, rel. Dir.Marcelo Trindade, j. 01.03.2005).

485 Cf. PAS CVM n. RJ 2009/8316, rel. Dir. Luciana Pires Dias, j. 09.04.2013; e PAS CVM n. RJ 2005/5132, rel. Pedro Oliva Marcilio de Sousa, j. 22.08.2006. 
da nova sociedade, sempre, é claro, sem abrir mão de demonstrar o caráter justificado da operação proposta.

Tais informações seriam, portanto, fundamentais para que os acionistas possam avaliar a relação de substituição de ações proposta e, eventualmente, questioná-la. Segundo G. TANTINI, é bem verdade que a relação de troca resulta da relação entre o capital social e o patrimônio da incorporadora e os da incorporada, sendo o resultado de uma equação a quatro incógnitas, ponderado ainda pela autonomia dos sócios na avaliação do negócio. No entanto, isso também significa que a deliberação (da relação de troca) é impugnável se os dados sobre os quais se funda são incompletos ou artificialmente alterados. ${ }^{486}$

Assim, uma primeira ordem de questionamentos levantada pelos acionistas sobre as relações de troca geralmente se dá em função dos critérios escolhidos para efetuar as avaliações das companhias ou de eventos que deveriam ter sido considerados em laudos de avaliação utilizados para a determinação da relação de troca, pois já vimos neste trabalho a necessidade de justificar pormenorizadamente aos acionistas os critérios que justificaram a relação de troca das ações, bem como a escolha do método de avaliação das companhias. Um exemplo desses questionamentos é o caso do Processo CVM n. RJ 2003/12770, rel. SEP, j. 26.12.2003, referente à incorporação das ações da Tele Centro Oeste Celular Participações S.A. (TCOC) pela Telesp Celular Participações S.A. (TCP), na qual os minoritários requereram interrupção do prazo de assembleia alegando que a relação de troca proposta era injusta porque não teria se baseado em nenhum critério de avaliação dos patrimônios da incorporada e da incorporadora, além do fato de que diversos relatórios de analistas de investimentos apontavam que a relação de substituição proposta deveria ser superior àquela indicada pelos acionistas controladores. ${ }^{487}$

486 Transformazione e Fusione... cit., p. 316.

487 No caso, a decisão foi de que a relação de troca não poderia ser estabelecida na ausência de algum critério de avaliação sob pena de se criarem condições artificiais de preço, tendo a CVM exigido a divulgação dos critérios e das razões que fundamentaram a relação de troca. Outro exemplo, o Processo CVM n. RJ 2007/11573 reflete de maneira clara que as divergências de interpretação dos fatores utilizados para apuração do valor da companhia pelo método do fluxo de caixa descontado podem ser gritantes. Nesse caso, alegam os reclamantes que o laudo de avaliação precisava ser revisto por conta de erros técnicos que causaram um valor aos minoritários $80 \%$ menor do que o correto. A decisão da CVM foi de não rever os laudos no caso em questão, pois entendeu que os pleitos requeriam uma investigação mais aprofundada e eram relativos a aspectos subjetivos da avaliação, que não poderiam ser apreciados no âmbito do processo de registro. 
Em outro caso, no Processo CVM n. RJ 2004/2274, rel. SEP, j. 20.04.2004, foi suscitada a obrigatoriedade de se levar em consideração indenização contingente decorrente do possível resultado de uma ação no valor do patrimônio da companhia incorporada, o que alteraria a relação de troca proposta. A decisão nesse caso negou a necessidade de considerar fatos contingentes no valor das companhias para calcular seu valor, mas decidiu que caso a demanda tivesse resultado favorável após a incorporação os acionistas poderiam buscar indenização pelo prejuízo que sofreram. ${ }^{488}$

Outro ponto relevante no processo informacional do acionista e que pode gerar atrito com acionistas minoritários diz respeito ao momento da divulgação das informações e, principalmente, da relação de troca determinada. Também no caso da incorporação entre TCP e TCOC citado acima se entendeu que a divulgação antecipada e não fundamentada da relação de substituição pela TCP foi prejudicial ao mercado e aos acionistas minoritários não só por estabelecer um teto à cotação de TCOC, mas também por dificultar a verificação do cumprimento, pelo controlador, das demais obrigações constantes na legislação. ${ }^{489}$ No mesmo processo, o parecer de J. A. TAVARES GUERREIRO defende que a incorporadora não pode divulgar ao mercado a relação de conversão das ações sem cumprir simultaneamente com os requisitos formais e substanciais dessas operações, especialmente a avaliação das ações e a realização da assembleia geral. Nesse mesmo sentido, completa A. LAMY FILHO ao dizer que

a fixação da relação de troca das ações, antecipada, sem observância de nenhuma das formalidades prescritas em lei, sem protocolo, sem justificação, sem laudo pericial de comparação dos patrimônios líquidos das empresas envolvidas, e demais procedimentos prescritos em lei para a proteção dos acionistas minoritários, e o regular funcionamento do mercado de capitais, teve o único efeito de fixar na Bolsa a cotação de

488 Em sentido bastante semelhante, vide Processo CVM n. RJ 2006/3160, rel. SEP, j. 18 e 30.05 .2006 em que se concluiu que "a CVM não pode e não deve impedir a realização de uma operação societária não sujeita a registro com base no fato de que, no futuro, caso a obrigação de pagamento venha a tornar-se definitiva, os acionistas minoritários terão dificuldades (decorrente da aparente necessidade de propositura de outra ação judicial) em receber a diferença que lhes seja devida pela valorização da companhia incorporada. A CVM não pode paralisar a vida societária de uma companhia no pressuposto de um evento futuro e incerto".

489 É evidente que a divulgação da relação de troca pode ser justificada e até mesmo necessária por constituir fato relevante cuja divulgação é obrigatória, principalmente no contexto pós-aquisição de controle em que o adquirente é obrigado a revelar os planos futuros e eventos societários que pretenda promover. O que se contesta, portanto, é essa divulgação não acompanhada dos demais requisitos da lei. 
ações de investidores minoritários [...]. ${ }^{490}$

Com base nessas opiniões, entendeu a autarquia que a divulgação da relação de substituição sem dar conhecimento de todos os seus elementos ao mercado possibilitava a caracterização de processo destinado a interferir na formação de preços das ações da TCOC, uma vez que a decisão de comprar ou vender ações não poderia prescindir do pleno conhecimento das bases em que se apoiara a divulgação relativa aos dois patrimônios

Por fim, é comum também haver impugnações por conta do tempo transcorrido entre as operações e a determinação da relação de substituição das ações. ${ }^{491}$ No mesmo caso citado acima, o então presidente da CVM Luiz Leonardo Cantidiano questiona a adequação da relação de troca proposta em função do tempo transcorrido entre sua divulgação e a época em que dita operação iria se concretizar, quando a realidade de cada uma das companhias já era bastante diversa do que à época da divulgação e considerando que o desempenho das duas empresas durante esse período foi bastante diferenciado. No mesmo sentido, impugnações em vista do tempo transcorrido entre o balanço utilizado para fundamentar a relação de substituição e a data do protocolo e realização da operação também poderiam ser objeto de questionamento pelos minoritários, já que, como vimos, não existe na Lei das S.A. um prazo máximo entre a data a que se refere a avaliação e a data da deliberação da assembleia geral que aprova a operação.

Ao se deparar com essas questões, ainda que a CVM não possa ou prefira não alterar a opinião do avaliador ou entrar no mérito das operações societárias, dos administradores e do acionista controlador que optaram por determinado critério, a autarquia não pode aceitar um laudo de avaliação que contenha erros evidentes decorrentes da não aplicação das regras construídas pela prática doutrinária e de mercado ou mesmo da aplicação de uma técnica de avaliação que resulte em conclusões discrepantes com a boa prática. Considerando que o laudo é utilizado para referendar a relação de troca proposta pelos administradores, a CVM teria competência, e mesmo o dever, de determinar que as instituições responsáveis pela elaboração do laudo de avaliação esclareçam todas as

\footnotetext{
490 Vide também em A. LAMY FILHO, Temas de S.A. - exposições e pareceres, Rio de Janeiro: Renovar, 2007, p. 396.

491 Vide, por exemplo, Processo CVM n. RJ 2003/12770, rel. SEP, j. 26.12.2003.
} 
obscuridades e que procedam aos ajustes oriundos de erros de natureza técnica do laudo. Ainda que a CVM não possa alterar a opinião do avaliador ou interferir na opção por determinado critério, não pode também a autarquia aceitar um laudo que contenha erros, tendo plena competência para determinar o saneamento de tais documentos. ${ }^{492}$

Assim, a autarquia pode e deve regulamentar e se pronunciar acerca de procedimentos (e conceitos a eles correlatos), como características do avaliador, conflito de interesses e isenção na confecção de laudos, observância de quóruns e formalização de assembleias, obrigação de a companhia fornecer premissas e números corretos aos avaliadores, entre outras, inclusive a obrigatoriedade de o avaliador levar em conta este ou aquele acontecimento. Em recente julgamento, o então relator Diretor Eli Loria, ao apreciar um laudo no contexto de oferta pública de cancelamento de registro, afirmou que todos os eventos relevantes ocorridos nos negócios da companhia até a data da elaboração do laudo deveriam ser considerados para quantificação do preço justo e que essa determinação "não representa uma intromissão da CVM na avaliação do preço justo das ações, uma vez que, ao considerar os eventos relevantes posteriores à data-base, o avaliador pode concluir que tais fatos não alteram o valor da avaliação já estabelecido". 493

É evidente, no entanto, que erros ou formalidades dos relatórios não podem ser confundidos com divergências de entendimentos entre avaliadores ou investidores, pois o avaliador conta com discricionariedade de julgamento em relação às premissas e aos métodos para avaliação da companhia decorrentes de sua independência técnica para realizar a avaliação. Nesse sentido, a CVM tem como dever a promoção da transparência e higidez das informações pelo exercício de poderes vinculados previstos na lei, de modo que os investidores possam tomar a melhor decisão sobre as suas operações no mercado de capitais, mas deve se abster de interferir de maneira substantiva em questões de mercado. $^{494}$

492 Cf. L. SILVA, $O$ valor justo em incorporação... cit., p. 64-65. No mesmo sentido, a jurisprudência italiana já admitiu "il principio dell'insindacabilità in sede giurisdizionale dei critério adottati per la determinazione del rapporto de cambio, salvo che nell'ipotesi di critei manifestamente illogici, irragionevoli o arbitrari [...]" (cf. L. A. BIANCHI, Il Giudizio di "Congruità"... cit., p. 44).

493 Cf. Processo CVM n. RJ 2010/14197, rel. Dir. Eli Loria, j. 26.10.2010. Também no Processo CVM n. RJ 2010/8551, rel. Dir. Luciana Pires Dias, j. 26.04.2011, essa tendência foi mantida e reafirmada.

494 Vide M. Carvalhosa, Comentários à Lei de Sociedades Anônimas, 5. ed. São Paulo: Saraiva, 2007, p. 72-73. No mesmo sentido, no Processo CVM n. RJ 2007/4022, j. 14.09.2007, o Colegiado decidiu com 


\subsubsection{Deveres Fiduciários dos Administradores}

As legislações societárias geralmente impõem deveres e padrões de conduta gerais e abstratos aos administradores com relação à companhia, aos acionistas e a terceiros com o intuito de orientar sua atuação em cada caso concreto. Entre os deveres tipicamente previstos, destacam-se os deveres de diligência e lealdade. ${ }^{495}$

O dever de diligência funciona como a pedra fundamental de todos os demais deveres previstos para regrar a atuação da administração nas companhias, exigindo que os administradores atuem de acordo com o parâmetro do homem ativo e probo de negócios e ajam de modo prudente e informado na condução dos negócios sociais de acordo com padrões previamente determinados pela legislação. ${ }^{496}$ Por sua vez, o dever de lealdade exige da administração uma atuação de boa-fé a serviço da companhia e sempre no que os administradores considerarem ser o melhor interesse dela. ${ }^{497}$

Como já dissemos, os termos das operações de incorporação são, na maioria das vezes, determinados pela administração das respectivas companhias, as quais ficam encarregadas de negociar o protocolo da operação posteriormente apresentado aos acionistas. Além disso, alguns atos da incorporação, como a subscrição do capital da sociedade incorporadora, são realizados pelos próprios administradores da sociedade. Sendo assim, não há dúvida de que os deveres fiduciários dos administradores se aplicam também na negociação e condução das operações de incorporações, ainda mais

base no Memo/SRE/GER-1/N. 291/2007 o qual, ao tratar dos laudos de avaliação, reconhece que a avaliação tem sempre um grau de discricionariedade do avaliador, devendo a CVM zelar pela transparência das informações, critérios e procedimentos utilizados, bem como as fontes e os documentos em que se baseou o laudo. A seu turno, N. EIZIRIK, comentando o preço justo em operações de cancelamento de registro, entende que "[a] Lei das S.A. não conferiu à Comissão de Valores Mobiliários poderes para questionar o preço oferecido nas ofertas públicas de fechamento de capital, mas apenas para obrigar o acionista controlador a fundamentar o referido preço e a prestar todas as informações necessárias para que os acionistas minoritários tenham condições de avaliar se ele é efetivamente "justo"” (A Lei das S/A comentada, v. I, São Paulo: Quartier Latin, 2011, p. 82). PEDREIRA (Coord.), Direito das companhias, v. 1, cit., p. 1091. 1098.

497 (Coord.)Idem, ibidem, p. 1129. 
considerando a magnitude dessas operações e seus efeitos sobre os acionistas, ${ }^{498}$ cujo descumprimento ensejará a responsabilização dos administradores por danos causados diretamente à companhia. A atribuição de responsabilidade aos administradores é, aliás, ponto crucial para garantia de defesa dos interesses dos acionistas de cada sociedade, garantindo que os administradores atuarão no seu melhor interesse. 499

Exemplificativamente, a European Communities Comission reconhece que a exigência de apresentação de justificação pela administração aos acionistas tem o intuito principal de fazer com que a administração assuma responsabilidade pelos termos da incorporação, notadamente pela relação de troca negociada, já que é ela a essência da operação que precisa ser justificada aos acionistas. ${ }^{500}$ No mesmo sentido, o art. 20 da Diretiva 2011/35 exige que a legislação dos Estados-membros regule, pelo menos, a responsabilidade civil dos membros do órgão de administração ou de direção da sociedade incorporada para com os acionistas dessa sociedade, decorrente das irregularidades cometidas pelos membros desse órgão especificamente na preparação e realização das operações de fusão ou incorporação.

A avaliação dos deveres fiduciários dos administradores torna-se ainda mais importante em operações de incorporação envolvendo companhias em que não se identifica um acionista controlador responsável por iniciar, conduzir e/ou aprovar a operação, fazendo com que a carga de responsabilidade da administração da companhia que deu início ao processo de incorporação seja mais acentuada. Nesses casos, cabe aos administradores cumprirem seus deveres de diligência, lealdade, vigilância e informação em grau máximo e verificar se as operações não afetam o estado dos sócios anterior à operação de maneira injustificada, uma vez que os administradores podem ser considerados responsáveis perante os acionistas na qualidade de gestores de interesse alheio. ${ }^{501}$ Os deveres de diligência nessa hipótese tornam-se tão importantes que E. F. DE

498 Vide nesse sentido C. M. TOMAZELla, Proteção de acionistas e credores... cit., p. 37.

$499 \mathrm{Na}$ verdade, mais importante do que determinar quem redige o protocolo, as legislações devem determinar quem assume responsabilidade por seus termos (cf. C. M. TOMAZELLA, Proteção de acionistas e credores... cit., p. 36).

500 Cf. European Communities Commission, Report on the Draft Convention... cit., p. 49.

501 Vide nesse sentido E. F. DE PONTES, Incorporação de ações no direito brasileiro... cit., p. 108. As operações de incorporação seguiriam, portanto, na linha daquilo que ORLANDO GOMES caracterizou como gestão no interesse de outrem, a qual difere da gestão de negócios. Esta não se confunde com aquele porque a gestão de negócios tem início por livre iniciativa do gestor, enquanto a gestão no 
PONTES entende que deixariam de ser analisados sob a faceta do business judgment rule, para serem vistos sob a óptica da doutrina do mandatário na acepção romana, associado ainda a um forte dever de informar, já que os administradores não prestam contas a um controlador definido. ${ }^{502}$

Cabe, portanto, avaliar o papel que esses deveres desempenham e como eles influenciam a negociação de tais operações, notadamente a questão referente à determinação da relação de substituição de ações, tendo em mente que tais deveres fiduciários devem ser avaliados em um contexto muito específico de uma operação que não se relaciona com a gestão do objeto social, mas que foge das atividades cotidianas da companhia e tem impacto direto na estrutura da empresa. ${ }^{503-504}$

Como um primeiro limite à liberdade dos administradores em negociar a relação de troca encontra-se, naturalmente, sua obrigação de buscar o interesse social e agir com lealdade em relação aos acionistas minoritários. ${ }^{505}$ Entre os exemplos de condutas que podem dar causa à responsabilização dos administradores perante os acionistas por atos que lhe venham a causar prejuízos, M. V. VON ADAMEK cita expressamente o "erro na determinação da relação de troca de ações na operação de fusão". ${ }^{506}$ Da mesma maneira, comentando o art. 114 do Código das Sociedades Comerciais de Portugal, R. VENTURA

interesse de outrem decorre de imposição legal ou obrigação contratual (Obrigações, 17 ed., Rio de Janeiro: Forense, 2007, p. 290). No caso das incorporações, é dever fiduciário da administração gerir o interesse dos acionistas durante todo o processo das operações de incorporação por imposição legal (cf. E. F. DE PONTES, Incorporação de ações no direito brasileiro... cit., p. 43).

502 Cf. E. F. de PONTES, ibidem, p. 129. A equiparação dos poderes dos administradores aos mandatários é, no entanto, bastante criticável do ponto de vista da Lei das S.A. que consagrou a teoria orgânica da administração, mas serve como indicação de uma situação especial no contexto da qual tais deveres devem ser considerados (cf. A. LAMY FILHO; J. L. BUlHÕES PEDREIRA (Coord.), Direito das companhias, v. 1, cit., p. 1098; e M. V. VON ADAMEK, Responsabilidade civil... cit., p. 30 e ss.).

503 Cf. M. V. VON ADAMEK, nesse sentido, entende que o dever de diligência deve ser analisado em cada caso concreto para se verificar a atitude que poderia ser esperada do legislador naquela situação (Responsabilidade civil... cit., p. 126).

504 Esse fato levou alguns autores, inclusive, a questionarem se os deveres fiduciários nesses casos estariam adstritos ã mera obrigação de meio sem nenhum compromisso com o resultado, como são geralmente entendidos, ou se deveriam, notadamente nos casos de operações em que não existe um acionista controlador, ser considerados uma exceção à regra de exclusão da responsabilidade por resultados. Vide nesse sentido E. F. DE PONTES, Incorporação de ações no direito brasileiro... cit., p. 111.

506 Responsabilidade civil... cit., p. 203. 
menciona como hipótese de responsabilização dos órgãos da administração a incorreção na relação de troca de ações. ${ }^{507}$

No contexto das operações de incorporação, portanto, tais deveres fiduciários se traduzem, em primeiro lugar, na obrigação de tentar negociar e obter uma relação de troca tendencialmente máxima ${ }^{508}$ e de celebrar protocolos de incorporação cuja relação de troca esteja necessariamente dentro do intervalo que permita que a operação seja considerada justificada para a sociedade em benefício da qual atuam tais administradores. Do contrário, caso a incorporação não esteja alinhada com o interesse social, sua concretização dará ensejo à responsabilização do administrador por descumprimento dos seus deveres de diligência e lealdade. ${ }^{509}$ A doutrina norte-americana, nesse ponto, é bastante enfática ao dizer que uma das obrigações dos administradores ou dos comitês independentes constituídos é a de obter o maior preço possível para a operação. ${ }^{510}$

Em segundo lugar, o cumprimento dos deveres fiduciários exige que os administradores tomem todas as diligências necessárias à avaliação das companhias e procedam à negociação da relação de troca com base em tais informações com o fim de garantir aos acionistas que esta seja justa e vantajosa, impedindo que a operação gere perda de valor a eles. ${ }^{511}$ Para esses fins, é bastante comum contar com a presença de assessores financeiros e jurídicos contratados pelas companhias atuando no interesse de todos os lados da operação. Tais assessores desempenham importantes funções como (i) identificação da relação de troca adequada e emissão de fairness opinions $;{ }^{512}$ (ii) auxílio à administração a lidar com temas que não fazem parte do dia a dia da companhia, emprestando aos

507 Fusão, cisão, transformação... cit., p. 294.

508 Cf. A. VICARI, Gli Azionisti... cit., p. 75.

509 Cf. C. M. TOMAZELLA, Proteção de acionistas... cit., p. 50.

510 Vide item 2.2 deste trabalho.

511 Cf. P. C. ARAGão, O Parecer de Orientação 35/2008 da CVM, in: M. V. VON ADAMEK (Coord.), Temas de direito societário e empresarial contemporâneos, Brasil: Malheiros, 2011, p. 527; A. VICARI, Gli Azionisti... cit., p. 777-78.

512 Muito comuns no direito norte-americano, as fairness opinions têm se tornado populares no Brasil e mostram-se como importante instrumento para demonstração pela administração de cumprimento de seus deveres fiduciários. Tais documentos são estudos elaborados por instituições financeiras e emitidos em determinadas operações a pedido e em favor da administração das companhias com o intuito de assegurar que é justa a contraprestação estipulada. Ao negociarem certa operação, os administradores, antes de se comprometerem de maneira irretroativa, buscam a emissão de tais documentos para evitar que eventuais acionistas litiguem contra eles alegando inadequação ou suposto exagero na contraprestação estipulada via relação de troca em prejuízo à companhia. Vide, sobre esse ponto, E. F. DE PONTES, Incorporação de ações no direito brasileiro... cit., p. 124. 
administradores sua expertise na área; e (iii) intermediação de negociações entre as companhias por meio de mandatos. ${ }^{513}$

A participação de tais assessores, na verdade, tem se tornado quase que uma concretização da obrigação fiduciária de diligência imposta à administração das companhias, de modo que os administradores conseguiriam praticamente se eximir do cumprimento de seus deveres fiduciários provada uma correta e diligente contratação de assessor financeiro. Conforme explica M. V. VON ADAMEK, o Judiciário não tem o poder de fazer uma análise retrospectiva da gestão para saber se as decisões da administração foram acertadas ou não, mas pode condenar os administradores se ficar comprovado que as escolhas de gestão foram feitas de improviso, sem que o administrador tenha avaliado as vantagens e desvantagens da operação, ainda mais no caso das incorporações por não se tratar de operações corriqueiras. ${ }^{514}$ A contratação de assessores adequados, porém, pode não apenas amenizar eventuais descumprimentos de deveres fiduciários, mas até fazer com que tais deveres sejam considerados cumpridos, ainda mais se associados a um efetivo exercício de vigilância sobre tais assessores por parte da administração. ${ }^{515}$ Não obstante, o administrador tem sempre o dever de se informar e de não confiar de maneira irrestrita nem nos relatórios elaborados internamente nem nos consultores contratados, cabendo a ele verificar se as informações apresentadas são suficientes e se abordam todos os aspectos do problema, exigindo esclarecimentos e eventuais revisões se assim acharem conveniente. ${ }^{516}$

Por fim, sabe-se que os administradores não são mandatários dos acionistas, mas corporificam órgãos da companhia e, uma vez eleitos, devem agir em nome da sociedade e não de um acionista que o elegeu. ${ }^{517}$ Nesse sentido, o art. 154 da Lei das S.A.

513 Cf. Idem, ibidem, p. 109

514 M. V. VON ADAMEK, Responsabilidade civil... cit., p. 128

515 Cf. E. F. DE PONTES, Incorporação de ações no direito brasileiro... cit., p. 109. O autor complementa defendendo ainda que em tais casos o assessor deve ter sua responsabilidade apurada não apenas contra a companhia, mas eventualmente também contra a massa de acionistas, mesmo que a lei societária atual seja carente de critérios claros de responsabilidade objetiva nesses casos, diferentemente do que já ocorre no direito comparado em que a responsabilidade de tais atores na qualidade de gatekeepers encontra-se mais bem desenhada. Há casos, por exemplo, em que o papel de tais assessores aproxima-se ao de um coordenador líder em oferta pública de distribuição, pois parte de seu trabalho é assegurar aos administradores e, por via indireta, aos acionistas, certo resultado patrimonial e político ao fim da operação.

516 Cf. PAS CVM n. 08/2005, rel. Dir. Eli Loria, j. 12.12.2007.

517 Cf. M. CARValhosa, Comentários à Lei de Sociedades Anônimas, v. 3, cit., p. 283. 
prevê que o administrador deve exercer suas funções "para lograr os fins e no interesse da companhia", sendo-lhe vedado faltar a esse dever "para a defesa dos interesses dos que o elegeram". Da mesma maneira, o art. 155 determina que o administrador deve "lealdade à companhia” e não a terceiros. Portanto, os administradores devem negociar as operações de incorporação em benefício de todos os seus acionistas e não apenas do controlador ou dos acionistas que os elegeram. ${ }^{518}$ Nesse sentido, poderia ser configurado descumprimento dos deveres fiduciários da administração a negociação e proposta para aprovação de relações de troca que sejam benéficas apenas a determinados acionistas em detrimento dos demais. Mais sobre esse ponto, inclusive, discutiremos nos capítulos seguintes quando abordarmos as questões das relações de troca diferenciadas entre ações da mesma espécie e classe.

\subsubsection{Abuso de Poder de Controle}

Ao erigir a figura do acionista controlador a uma quarta instância societária e colocando-o na posição de verdadeiro intérprete do interesse social, a Lei das S.A. atribuiu a ele um verdadeiro direito-função, fixando-lhe poderes, deveres e responsabilidades que, se não observados, configuram abuso de poder de controle. ${ }^{519}$ Entre tais deveres, está a obrigação de fazer com que a companhia realize seu objeto e exerça sua função social. Além disso, existem verdadeiros deveres fiduciários, notadamente de lealdade, impostos pela Lei das S.A. ao acionista controlador perante os demais acionistas quando o art. 116 da lei atribuiu ao controlador "deveres e responsabilidades com os demais acionistas da empresa" a quem "deve lealmente respeitar e atender". 520

Essa definição de deveres e responsabilidades é especialmente importante nas operações de incorporação entre companhias que apresentam um acionista controlador

518 Cf. texto do PO CVM 35. R. VENTURA também afirma que a negociação do protocolo deve tomar em conta a generalidade dos sócios (Fusão, cisão, transformação... cit., p. 78).

519 Cf. A. LAMY FILHo; J. L. BUlhões PEDReIRA (Coord.), Direito das companhias, v. 1, cit., p. 1119; F. K. COMPARATO; CALIXTO SALOMÃo FILHO, O poder de controle na sociedade anônima, 4. ed., Rio de Janeiro: Forense, 2005, p. 363.

520 Ver CAliXto SALOMÃo FILHO, O novo direito societário cit., p. 151, que vê deveres fiduciários do controlador para com os demais acionistas a quem deve respeitar e atender lealmente. Ver também E. VALlADÃO A. e N. FRANÇA que expressamente defende a existência de um dever de lealdade do acionista controlador com os demais acionistas (Dever de lealdade do acionista controlador... cit., p. 254 e ss.; e M. CARvalhosA, Comentários à Lei de Sociedades Anônimas, v. 2, cit., p. 485. 
definido, pois, nesses casos, o processo de incorporação tem um fluxo próprio: usualmente, a proposta parte do acionista controlador, envolvido diretamente nas negociações e na definição da relação de troca de ações, descendo, de maneira hierárquica para a administração, responsável depois por retransmitir as informações para os demais acionistas. ${ }^{521}$ Diferentemente do que ocorre nas companhias em que não existe controlador definido, os deveres fiduciários dos administradores correm à sombra dos deveres e das responsabilidades do acionista controlador e do eventual exercício abusivo desse poder. A existência de um controlador definido pode, ainda, não apenas aprovar a operação, mas influenciar outros acionistas amenizando a carga de dissidências e debates em assembleia. ${ }^{522}$

Assim, a autorização que é dada ao controlador para deliberar pela minoria e, dessa maneira, dispor dos direitos patrimoniais de tais acionistas, não vem sem contrapartida. A ele cabe o dever societário de defender os legítimos interesses de todos os acionistas e não restringi-los indevidamente no quadro do interesse comum. ${ }^{523}$ Evidente, portanto, que as normas referentes aos deveres do controlador e abuso do poder de controle serão também instrumento de defesa dos acionistas minoritários na hipótese de imposição de uma relação de troca desfavorável no contexto de uma operação de incorporação. Embora os minoritários não tenham um direito certo à manutenção de sua participação originária na sociedade resultante da operação de incorporação, também é certo que não há um poder ilimitado para o acionista controlador modificar o status quo de todos os acionistas a seu bel-prazer. Assim, muito embora seja inegável que a decisão das operações de incorporação é tomada de acordo com o princípio da maioria, e aos sócios que não concordam cabe aceitar a decisão ou exercer eventual direito de retirada (se aplicável), a contrapartida do poder dado ao acionista controlador exige que essa decisão não seja

521 Quanto à influência do controlador na administração, vide J. A. TAVARES GUERREIRO, Sociologia do poder na sociedade anônima, Revista de Direito Mercantil Industrial, Econômico e Financeiro, n. 77, São Paulo: RT, 1990, p. 52; G. D. C. PEREIRA, Alienação do poder de controle... cit., p. 10; e A. B. A. MARGONi; C. D. TAVARES GUERREIRO, Exercício abusivo do poder de controle e o dever de reparar o dano, in: R. R. MONTEIRO DE CASTRo; W. J. WARDE JR.; C. D. TAVARES GUERREIRo (Coord.), Direito empresarial e outros estudos em homenagem ao Professor José Alexandre Tavares Guerreiro, São Paulo: Quartier Latin, 2013, p. 484.

522 Cf. E. F. DE PONTES, Incorporação de ações no direito brasileiro... cit., p. 141 e 144.

523 Cf. E. VAlladÃo A. e N. FRANÇA citando julgado do caso Victoria de 1931 (Victoria Urteil) proferido pelo Tribunal do Reich alemão (Dever de lealdade do acionista controlador... cit., p. 255). 
tomada em seu benefício exclusivo e à custa dos minoritários, e sim de acordo com o interesse social. ${ }^{524}$

Não por outra razão, N. EIZIRIK entende que a liberdade de contratar a relação de substituição de ações é limitada pelo dever legal do acionista controlador de exercer seu poder de controle no interesse da companhia e a consequente definição, como modalidade expressa de exercício abusivo do poder de controle, de "promover a incorporação da companhia com o fim de obter, para si ou para outrem, vantagem indevida, em prejuízo dos demais acionistas", conforme o art. $117,1 .^{\circ}, b{ }^{525}$

Portanto, uma decisão que responda apenas aos interesses da maioria pressupõe uma lesão aos direitos dos minoritários e implica uma redefinição dos direitos de tais acionistas que configura verdadeira expropriação de direitos dos minoritários, caracterizando abuso de poder por parte do acionista controlador. ${ }^{526}$

Dessa maneira, seja qual for a justificativa da operação de incorporação, é fundamental que seja demonstrado que ela atende ao interesse social conforme demonstramos aqui de forma que assegure a maximização da rentabilidade do acionista, a prosperidade da empresa e o acúmulo do patrimônio social. ${ }^{527}$ Em sentido semelhante, mas no contexto de uma cessão de controle empresarial, E. VALlADÃo A. E N. FRANÇA expressamente ressalta o dever do controlador de maximizar o valor das ações dos acionistas não controladores como medida que se espera do leal comportamento daquele que tem o poder de determinar os destinos da empresa. ${ }^{528}$

O limite ao poder do controlador também se manifesta na obrigatoriedade de se respeitar e elaborar uma estimativa objetiva dos patrimônios sociais que se unirão com a

\footnotetext{
524 Vide nesse sentido A. PÉREZ TroyA, La determinación del tipo de canje... cit., p. 36; e A. B. A. MARGONI; C. D. TAVARES GUERREIRO, Exercício abusivo do poder de controle... cit., p. 483.

525 A Lei das S/A comentada... cit., p. 227.

526 Vide nesse sentido A. PÉREZ TroyA, La determinación del tipo de canje... cit., p. 36.

527 Cf. N. EIZIRIK, A Lei das S/A comentada... cit., p. 235; F. K. COMPARATO; CALIXTO SALOMÃo FILHO, O poder de controle... cit., p. 382; e M. CARVALHOSA, Comentários à Lei de Sociedades Anônimas, v. 2, cit., p. 509.

528 Dever de lealdade do acionista controlador... cit., p. 257.
} 
operação de incorporação de forma a proteger o patrimônio dos acionistas com a conclusão da operação negociando a melhor relação de troca. ${ }^{529}$

Por fim, o art. 15 da ICVM 319 traz alguns casos específicos e já especificados que serão considerados abuso de poder de controle, dando maior concretude ao conceito visto acima, sem prejuízo às demais disposições legais ou regulamentares. Não surpreendentemente, a maioria dos casos mencionados pela ICVM 319 diz respeito à determinação da relação de substituição de ações, dada a importância da matéria. Entre tais casos, destacam-se (i) o aproveitamento pelo controlador do valor do ágio pago na aquisição do controle de companhia aberta no cálculo da relação de substituição das ações dos acionistas não controladores; (ii) o não reconhecimento, no cálculo das relações de substituição das ações dos acionistas não controladores estabelecidas no protocolo da operação, da existência de espécies e classes de ações com direitos diferenciados, com a atribuição de ações, com direitos reduzidos, em substituição àquelas que se extinguirão, de modo que favoreça, direta ou indiretamente, outra espécie ou classe de ações; e (iii) a adoção, nas relações de substituição das ações dos acionistas não controladores, da cotação de bolsa das ações das companhias envolvidas, que não integrem índices gerais representativos de carteira de ações admitidos à negociação em bolsas de futuros. No campo da tutela da informação dada aos acionistas, a ICVM 319 também considera como abuso de poder de controle a inconsistência, a omissão ou o retardamento injustificado na divulgação de todas as informações que tenham sido postas à disposição do controlador ou por ele utilizados na avaliação, no planejamento e na execução de operações de incorporação envolvendo companhia aberta. ${ }^{530}$

\subsubsection{Síntese Parcial}

Ao longo de toda esta Seção II, abordamos as questões que envolvem a relação de troca e sua natureza jurídica, para depois examinar quais os parâmetros que regulam a sua determinação nas operações de incorporação.

529 Cf. C. Santagata, La Fusione Tra Società... cit., p. 282. Para o autor, essa obrigação é ainda mais marcante já que defende uma determinação da relação de troca pura, baseada exclusivamente na comparação dos patrimônios das sociedades envolvidas, e admite variações apenas na diversidade que a utilização dos bens sociais pode assumir na nova sociedade. A deliberação da maioria, portanto, não seria um poder dispositivo, e sim um poder de averiguação (accertamento) da relação de troca.

530 Cf. L. S. DE ARAGÃo, Dever de informar e operações de reorganização societária... cit., p. 93-96. 
Nesse contexto, examinamos, em primeiro lugar, todo o processo especificamente prescrito pela Lei das S.A. para regular as operações de incorporação, analisando quais são as exigências legais que poderiam incidir sobre a negociação da relação de troca. Vimos, assim, os requisitos que devem constar no protocolo, notadamente quanto aos critérios utilizados para determinar as relações de substituição, bem como analisamos as regras que tratam sobre a avaliação do patrimônio ou das ações a serem incorporadas ao capital da sociedade incorporadora e sobre a manifestação dos peritos e conselheiros fiscais para concluirmos que, a princípio, vige o princípio da liberdade contratual na determinação da relação de substituição de ações, o que dá uma margem considerável de negociação para as companhias.

Por outro lado, dissemos também que a relação de troca não corresponde a um simples "preço" encontrado em contratos de permuta que pode ser negociado a critério exclusivo de um único sujeito, mas se insere no contexto de uma operação societária que traz uma série de outras balizas legais que delimitam as fronteiras da sua livre negociação. Foram essas balizas principais que buscamos analisar na sequência deste capítulo.

Vimos primeiramente que o princípio da realidade do capital social, muitas vezes mencionado como um delimitador da relação de troca de ações, pouco auxilia na efetiva determinação do número de ações que será atribuído a cada acionista e, portanto, na proteção dos acionistas tanto da incorporadora quanto da incorporada contra diluições injustificadas.

Em sentido oposto, a figura do interesse social surge como o alicerce da análise da validade das operações de incorporação e como figura de importância nuclear para a determinação da relação de troca de ações, definindo um intervalo no qual diferentes relações de substituição podem ser negociadas, mas sob a condição de que, em qualquer caso, chegue-se a uma maximização da rentabilidade do acionista com a concretização da operação de incorporação, seja pela expectativa de obter melhores resultados em termos de fluxos de caixa, lucros ou dividendos, seja pelo aumento da sua quota proporcional de participação na sociedade resultante da operação. Nesse contexto, defendemos também que a relação de troca não precisa decorrer necessariamente da exata comparação entre os dois patrimônios das sociedades envolvidas como condição para sua validade e atendimento ao interesse social. 
Em paralelo, analisamos outras possíveis barreiras à determinação da relação de substituição de ações geralmente mencionadas pela doutrina e decisões administrativas, i.e., os conceitos de valor justo e tratamento equitativo. Nesse ponto, vimos que o conceito de um valor intrinsecamente justo tem pouca serventia para efetivamente regular a relação de substituição de uma operação de incorporação, dadas as diferentes acepções que se atribui a esse termo e a subjetividade do conceito. Na verdade, o conceito de justiça pode estar associado a certo eixo de equivalência nas operações dentro do qual os administradores podem negociar diferentes relações de troca. Além disso, essa ideia de justiça de uma operação pode estar associada mais ao modo de negociação de uma operação, quando ela for similar ao que seria negociado entre partes independentes em um processo sem conflitos de interesses, do que efetivamente a um valor de relação de troca que seja intrinsecamente justo.

O conceito do tratamento equitativo, por sua vez, mostra-se bastante controvertido, tanto na acepção do termo quanto na extensão da sua aplicação para as operações de incorporação. Ainda assim, dada a natureza jurídica das incorporações e da própria relação de troca que viemos aqui demonstrando, entendemos que a regra de tratamento equitativo deve, sim, ser aplicada e, por isso, constitui importante restrição a ser observada nas operações de incorporação.

Por fim, também atuam em defesa dos acionistas minoritários as regras que regulam os deveres fiduciários dos administradores e do controlador, impedindo que negociações de troca que não atendam ao interesse social ou que discriminem os acionistas de modo ilegal sejam consideradas válidas, ensejando a responsabilização dos administradores ou do controlador, conforme o caso. Em ambos os casos, também vigem regras que regulam a divulgação de informações e asseguram a diligência do processo como modo de conferir maiores garantias aos acionistas e possibilitar que a relação de troca seja examinada e eventualmente contestada.

Feito esse panorama geral da regulação incidente sobre a determinação da relação de troca, os capítulos seguintes analisarão a questão em situações que trazem certas particularidades merecedoras de estudo específico. Evidentemente, muitos dos conceitos referidos acima, como tratamento equitativo, deveres fiduciários dos administradores e abuso de poder de controle, serão retomados ao longo dessa discussão. 


\section{4 \\ RELAÇÃO DE SUBSTITUIÇÃO DE AÇÕES EM SITUAÇÕES ESPECIAIS}

\subsection{Operações de Incorporação Envolvendo Companhias Abertas}

Operações de incorporação que envolvem companhias abertas têm certas particularidades além daquelas aplicáveis às demais companhias. Além dos casos específicos de abuso de poder de controle que tratamos no item 2.3.2.6 acima já previamente determinados pela ICVM 319, destacam-se outras particularidades impostas principalmente por esta instrução normativa que podem afetar a determinação da relação de substituição de ações ou que estejam com ela intimamente ligadas, as quais serão agora objeto de nosso estudo.

Em primeiro lugar, a preocupação com a divulgação de informações fez com que a CVM detalhasse um rol de elementos mínimos que devem ser divulgados ao mercado, entre os quais destacamos a divulgação daqueles que podem decididamente influenciar a relação de troca das ações, quais sejam: (i) os benefícios esperados, de natureza empresarial, patrimonial, legal, financeira e quaisquer outros efeitos positivos, bem como os eventuais fatores de risco envolvidos na operação; (ii) a estimativa dos custos de realização da operação; (iii) os critérios utilizados para determinar a relação de troca das ações e as razões pelas quais a operação é considerada equitativa para os acionistas da companhia; (iv) as ações que os acionistas preferenciais receberão, as razões para a modificação dos seus direitos, se houver, bem como eventuais mecanismos compensatórios para acionistas preferenciais que recebam ações com direitos distintos dos que detinham; (v) os critérios de avaliação do patrimônio líquido, a data a que será referida a avaliação, e o tratamento das variações patrimoniais posteriores; (vi) detalhamento da composição dos passivos e das contingências passivas não contabilizadas a serem assumidas pela companhia resultante da operação, na qualidade de sucessora legal; e (vii) declaração dos peritos ou da empresa especializada da existência ou não de algum conflito ou comunhão de interesses, atual ou potencial, com o controlador da companhia, ou em face de 
acionista(s) minoritário(s) desta, ou relativamente à outra sociedade envolvida, seus respectivos sócios, ou no que se refere à própria operação. ${ }^{531}$

Como se vê, as exigências adicionais feitas pela autarquia tentam suprir ou especificar de maneira mais detalhada elementos das operações de incorporação que não foram contemplados pormenorizadamente pela Lei das S.A. Exemplificativamente, a exigência feita pela divulgação a respeito dos benefícios esperados a serem obtidos com a operação, a estimativa dos custos de realização da operação e as razões pelas quais a operação é considerada equitativa para os acionistas da companhia é especialmente importante no contexto que viemos analisando aqui. Embora o uso do termo equitativo careça de significado preciso, a regulamentação específica proposta pela ICVM 319 tem o mérito de trazer a obrigatoriedade de que as companhias divulguem os benefícios e custos que as operações trarão aos acionistas, mostrando-se alinhada com a ideia de que o atendimento ao interesse social em tais operações deve ser detalhadamente justificado aos acionistas minoritários como requisito de validade de tais operações. Além disso, especificar por que a relação de troca pode ser considerada equitativa requer que se esclareça aos acionistas sobre que bases e pressupostos ela foi estabelecida, o que, a nosso entender, exige também que seja demonstrado de forma justificada como foram divididos os benefícios gerados com a operação entre as diferentes sociedades.

Integram também o rol de informações que devem ser divulgadas os critérios de avaliação do patrimônio líquido, a data a que se refere a avaliação e o tratamento das variações patrimoniais posteriores, bem como o detalhamento da composição dos passivos e das contingências passivas não contabilizadas a serem assumidas pela companhia resultante da operação, na qualidade de sucessora legal. A divulgação dessas informações é fundamental para que os acionistas possam avaliar a precisão, atualidade e adequação da relação de troca proposta sobre os valores de avaliação das sociedades e, como vimos, é bastante comum que haja questionamentos sobre os critérios utilizados para avaliação, datas desatualizadas de balanço ou fatos que deveriam ter sido considerados na determinação da relação de substituição das ações (em geral, passivos ou contingências) mas que não foram contemplados pelos respectivos laudos, de modo que a divulgação dessas informações auxilia na avaliação dos acionistas e facilita eventual contestação dos

531 Cf. art. 2. ${ }^{\circ}$ da ICVM $319 / 99$. 
termos contratados. Por fim, a ICVM 319 exige que as demonstrações financeiras que servirem de base para operações de incorporação, fusão e cisão envolvendo companhia aberta deverão ser auditadas por auditor independente registrado na CVM.

Especificamente sobre a questão da relação de troca, a ICVM 319 traz outros requisitos como (i) a exclusão do saldo do ágio pago na aquisição da controlada nas operações de incorporação entre controladora e controlada; (ii) o reconhecimento da existência de espécies e classes de ações com direitos diferenciados, sendo vedado favorecer, direta ou indiretamente, outra espécie ou classe de ações; e (iii) a vedação à adoção da cotação de bolsa das ações das companhias envolvidas, salvo se essas ações integrarem índices gerais representativos de carteira de ações admitidos à negociação em bolsas de futuros. Quanto ao primeiro ponto, a exclusão do saldo de ágio visa a evitar uma superavaliação do patrimônio da sociedade que levaria a uma distorção da relação de troca em prejuízo dos acionistas minoritários. ${ }^{532} \mathrm{O}$ segundo ponto exige que a relação de troca reconheça a diferença entre as diferentes espécies e classes de ações, o que estudaremos mais a fundo no item 3.3 abaixo. Por fim, a obrigatoriedade de que o critério de avaliação escolhido tenha pertinência com a companhia sendo avaliada, como discutido neste trabalho, fez com que a autarquia determinasse, de antemão, a vedação de utilização do critério de cotação em bolsa se as ações em questão não integrarem índices de liquidez.

Dadas as exigências adicionais trazidas pela ICVM 319, é comum haver pedidos de dispensa do cumprimento da instrução em determinadas operações. Nesse sentido, a Deliberação CVM n. 559/2008 atribuiu competência à SEP para dispensar o cumprimento da publicação na imprensa do fato relevante de que trata o art. $2 .^{\circ}$ da ICVM 319, da elaboração de demonstrações financeiras auditadas por auditor independente registrado na CVM e da elaboração de laudo com base no valor do patrimônio líquido das ações da controladora e da controlada, avaliados os dois patrimônios segundo os mesmos critérios e na mesma data, a preços de mercado, nos termos do art. 264 da Lei das S.A. Essa dispensa, no entanto, só pode ocorrer quando (i) a(s) companhia(s) aberta(s) envolvida(s) não possua(m) dispersão acionária ou acionistas minoritários que necessitem

532 Vide nesse sentido PAS CVM n. 24/04, j. 31.07.2007, cuja decisão deixa claro que mesmo que a ICVM 319 não estivesse em vigor, o ágio já deveria ser excluído em atendimento à boa técnica contábilfinanceira, sob pena de caracterizar exercício abusivo do poder de controle, por distorcer a relação de substituição das ações em prejuízo dos acionistas minoritários. 
de proteção, tampouco algum título ou valor mobiliário de sua emissão em circulação; ou (ii) a companhia aberta seja detentora de $100 \%$ do capital social da sociedade a ser incorporada ou da sociedade incorporadora (no caso de incorporação de controladora por controlada), de modo que a operação não resulte em aumento de capital na companhia aberta, bem como não resulte em alteração de participação dos acionistas de companhia aberta. Além dos casos especificamente previstos na Deliberação CVM n. 559/2008, o Colegiado já dispensou os requisitos adicionais da ICVM 319 em certos casos em que inexistiam acionistas minoritários a serem tutelados, as participações societárias da incorporada já estavam refletidas na incorporadora e inexistia relação de troca a ser determinada por conta da ausência de entrada de novos acionistas. ${ }^{533}$

Por fim, curioso notar que as operações de incorporação de ações não estão a princípio compreendidas pelas regras da ICVM 319, exceção feita ao parágrafo único do art. 12 de tal instrução no que trata da obrigatoriedade de auditoria das demonstrações financeiras que servirão de base para as operações em que as incorporações de ações foram expressamente referidas. ${ }^{534}$ Embora as incorporações de ações sejam distintas das incorporações de sociedades em muitos aspectos, algumas exigências adicionais previstas na ICVM 319 poderiam ser também aplicadas aos casos de incorporações de ações, notadamente aquelas referentes ao detalhamento das informações que devem ser postas à disposição dos acionistas antes da aprovação de tais operações, o que fez com que grande parte das incorporações de ações ocorridas no mercado praticasse certa equiparação com os procedimentos previstos na ICVM 319 mesmo na ausência de exigências legais.

\subsubsection{Edital de Audiência Pública SDM n.04/2013}

Em 20 de maio de 2013 a CVM lançou o Edital de Audiência Pública SDM n. 04/2013 contendo o já esperado projeto de reforma sobre regras aplicáveis às operações de fusão, cisão, incorporação e incorporação de ações envolvendo emissores de valores

533 Cf., por exemplo, Processo CVM n. RJ 2011/4880, rel. Dir. Eli Loria, j. 31.05.2011, Processo CVM n. RJ 2008/10328, rel. SEP, j. 28.10.2008; e Processo CVM n. RJ 2008/1821, rel. SEP, j. 04.03.2998.

534 Vide nesse sentido L. L. CANTIDIANO, Incorporação de sociedades e incorporação de ações... cit., p. 146; N. EIZIRIK, que chega a dizer que essa característica é essencial da operação de incorporação (Temas de direito societário... cit., p. 346; e E. F. DE PONTES, Incorporação de ações no direito brasileiro... cit., p. 77. 
mobiliários registrados na categoria A. ${ }^{535}$ Essa minuta deverá substituir a maior parte dos comandos da ICVM 319 que analisamos acima, aperfeiçoando as normas relativas a: (i) conteúdo mínimo das comunicações da companhia para o mercado sobre operações de fusão, cisão, incorporação e incorporação de ações; (ii) os deveres fiduciários dos administradores de companhias abertas envolvidas em tais operações; (iii) as demonstrações financeiras e informações financeiras pro forma a serem divulgadas em razão de tais operações; e (iv) os critérios e conteúdo mínimo dos laudos de avaliação elaborados para os fins do art. 264 da Lei das S.A. A minuta acrescenta ainda em relação à Instrução CVM n. 481/2009 um artigo referente aos documentos e às informações que a companhia deve fornecer quando uma assembleia geral for convocada para deliberar sobre as operações mencionadas acima. Como era esperado e em linha com a estratégia de regulação da CVM, a nova instrução alterou mais as questões relativas à divulgação de informações do que o mérito da relação de troca em si, inserindo uma série de exigências que ajudam a resguardar os direitos dos acionistas minoritários. ${ }^{536}$

Em primeiro lugar, vê-se desde logo que a proposta de regulação da autarquia engloba agora as operações de incorporação de ações junto com as incorporações de sociedades, diferentemente do que existe na ICVM 319, de modo que ambas as operações estarão sujeitas à mesma regulação se aprovada a minuta como foi proposta. Andou bem a nosso entender a autarquia, pois muitas das divulgações exigidas nas incorporações de sociedades aplicam-se também para os casos de incorporações de ações.

Uma primeira proposta de modificação diz respeito às demonstrações financeiras das sociedades envolvidas. Seguindo o que se vê a respeito na legislação europeia, que impõe um prazo máximo para o balanço a ser utilizado nas operações de incorporação, a minuta exige que todas as sociedades envolvidas divulguem suas demonstrações financeiras com a mesma data-base, a qual não poderá ser anterior a 180 dias da data da assembleia que deliberará sobre a operação de incorporação. A proposta insere, portanto, duas modificações significativas: a primeira, é a de deixar claro que todas as sociedades envolvidas deverão divulgar suas demonstrações financeiras, o que não está

\footnotetext{
535 Sobre os planos de reformar a instrução, vide entrevista com a Presidente da CVM Maria Helena Santana em 2009 (Momento de transformação, Revista Capital Aberto, Cobertura OCDE 2009, dez. 2009).

536 Vide Momento de transformação, Revista Capital Aberto, Cobertura OCDE 2009, dez. 2009.
} 
explícito na Lei das S.A. - que prevê apenas a avaliação do patrimônio da sociedade incorporada - nem na ICVM 319; a segunda é estabelecer um limite para a data de tais demonstrações financeiras. Não obstante algumas críticas a respeito dos custos de elaboração de tais demonstrações ou do prazo sugerido pela autarquia, entendemos ser louvável a tentativa de regulação da CVM, pois as demonstrações financeiras são utilizadas pelos acionistas para balizar seu voto e aceitar ou não as condições da incorporação, inclusive a relação de troca, e, por isso, a informação é muito mais útil quanto mais atualizada e melhor retratar as condições das sociedades envolvidas.

Outra inovação trazida na minuta é a exigência de que as sociedades envolvidas nas operações elaborem informações financeiras pro forma da sociedade que subsistir à operação, como se esta já existisse, pois essas informações seriam importantes para balizar o exercício do direito de voto dos acionistas e os ajudaria a avaliar os benefícios que as operações trariam. Essa exigência não encontra paralelo, por exemplo, na Diretiva 2011/35 e sofreu críticas por elevar os custos e dificultar o processo de incorporação, além de alguns questionamentos sobre a possibilidade de realizar tais demonstrações financeiras e da real utilidade desses demonstrativos pro forma como documento informacional para os acionistas já que o modo de elaboração de demonstrativos pro forma não necessariamente corresponde às regras de contabilização que serão utilizadas após a concretização da operação. ${ }^{537}$

A minuta proposta também endereçou a preocupação com a divulgação antecipada da relação de troca ou dos critérios para sua determinação que, como vimos, é fonte corriqueira de conflitos entre acionistas minoritários e controladores. Nesse sentido, a autarquia propõe que a divulgação da relação de troca "antes da conclusão das

537 As críticas foram feitas pelo fato de que tais demonstrações pro forma deveriam ser elaboradas na forma estabelecida pela Orientação Técnica do Comitê de Pronunciamentos Contábeis - OCPC n. 6. No entanto, a metodologia contábil dessa orientação técnica difere da metodologia do Pronunciamento Técnico CPC 15 já aprovado pela autarquia e que dispõe sobre a combinação de negócios. Poderia haver, portanto, questionamentos quanto à confiabilidade dos dados que integram as informações financeiras pro forma, já que não corresponderão às demonstrações financeiras elaboradas após a conclusão da operação. Além disso, em alguns casos, dependendo da complexidade das companhias envolvidas, a elaboração de informações financeiras pro forma não seria viável, considerando principalmente a tempestividade de divulgação da informação para fins de tomada de decisão. 
negociações" $" 538$ seja acompanhada de algumas informações adicionais, entre elas, (i) das razões que levaram à divulgação antecipada; (ii) estágio em que se encontram as negociações; (iii) circunstâncias em que a relação de substituição ou o critério divulgado ainda podem ser alterados; e (iv) em se tratando de proposta do acionista controlador, esclarecer se a proposta é vinculante, prazo para aceitação, medidas que a administração pretende tomar para avaliar a proposta e a data prevista para a conclusão das negociações.

Outras importantes inovações constam do anexo que contempla as informações que deverão ser fornecidas nos termos da Instrução CVM n. 481/2009 para as assembleias gerais convocadas para deliberar sobre as operações de incorporação. Entre tais informações, constam a divulgação obrigatória dos benefícios esperados, incluindo sinergias (especificando que os ganhos de sinergia devem ser necessariamente divulgados pelos administradores), benefícios fiscais, ganhos de eficiência, vantagens estratégicas, bem como os custos e fatores de risco envolvidos. Além disso, devem ser divulgadas eventuais alternativas que poderiam ter sido utilizadas para alcançar os mesmos objetivos, indicando os motivos pelos quais tais alternativas foram descartadas. Não obstante as críticas do mercado em relação a tais divulgações no sentido de que algumas dessas informações poderiam obrigar a companhia a divulgar informações sensíveis ao mercado, entendemos que o intuito da autarquia é muito positivo em tentar melhorar e detalhar o rol de informações que deve ser posto à disposição dos acionistas. Na linha do que viemos defendendo aqui neste trabalho, seria obrigatório divulgar quais os benefícios que a operação trará e até mesmo especificar por que a incorporação foi o mecanismo escolhido em detrimento de outras possibilidades, o que vai ao encontro justamente dos argumentos que expusemos anteriormente como sendo necessários para uma real justificação da relação de troca das ações aos acionistas.

De maneira geral, portanto, não obstante a necessidade de alguns ajustes à minuta posta em audiência pública, entendemos que foi positiva a medida proposta pela CVM com o intuito de melhorar o nível de informação colocada à disposição dos acionistas em operações de incorporação, aproximando a nossa legislação a outras como se

538 Criticável a falta de clareza da minuta no que se refere à expressão "antes da conclusão das negociações", pois não há nenhuma menção a que negociações específicas se está referindo. Melhor seria se a redação dissesse em relação de substituição ainda sujeita a alterações ou não definitiva. 
vê nos países europeus, cujos dispositivos referentes à divulgação de informações sobre a relação de substituição de ações são mais rigorosos.

\subsection{Operações Envolvendo Sociedades sob Controle Comum}

Conforme já dissemos, a independência das sociedades negociando as operações de incorporação - tanto do ponto de vista do controlador quanto dos administradores - é justamente um dos pressupostos sobre o qual se assenta a liberdade de contratação da relação de troca de ações tendo em vista que se assume que cada companhia buscará o que é melhor para si, de modo que uma relação de troca aprovada pelo controlador será também automaticamente benéfica para os acionistas minoritários.

Quando esse pressuposto não se verifica, como no caso de operações entre sociedades controladora e controlada ou sob controle comum, e no contexto de uma legislação em que a liberdade de contratação da relação de troca é bastante ampla como a brasileira, as operações de incorporação podem se tornar bem mais problemáticas. Uma vez que não existem duas partes independentes negociando a operação e defendendo os interesses das respectivas sociedades, ${ }^{539}$ não há como se assegurar o caráter equitativo da operação $^{540}$ nem que haja negociação com o intuito de garantir a maximização da rentabilidade para os acionistas de ambas as sociedades, e sim privilegiar a companhia em que o acionista controlador seja titular da maior participação societária. ${ }^{541}$

Existe, na verdade, um potencial conflito de interesses entre as companhias envolvidas para aprovar as deliberações nas respectivas assembleias, tendo em vista que quem aprova a operação é o mesmo acionista controlador em ambas as sociedades. Segundo GUIRÃO, é justamente no caso de união de empresas por fusão ou incorporação

539 Cf. A. LAMY FILHO; J. L. BULHÕES PEDREIRA, A Lei das S.A. (pressupostos, elaboração, aplicação)... cit., p. 680 e 683.

540 Cf. N. EIZIRIK, A Lei das S/A comentada... cit., p. 402. No direito americano encontram-se as mesmas preocupações conforme se vê na citação de V. BRUDNEY e M. A. CHIRELSTEIN: "the occasion for judicial imposition of fairness constraints upon the merger terms of parent-subsidiary mergers arises because the terms are unilaterally imposed by the parent, rather than freely bargained at arm's length" (Fair Shares in Corporate Mergers and Takeovers, 88 Harv. L. Rev., 1974-1975, p. 307).

541 Vide F. H. EASTERBROOK e D. R. FISCHEL ao afirmarem que "an investor holding a diversified portfolio with stock in both corporations is concerned with the total gain from the transaction, not with how the gain is allocated" (The Economic Structure... cit., p. 122). Em sentido semelhante, A. LAMY FILHO, Temas de S.A.... cit., p. 254. 
que esse conflito de interesses pode alcançar o seu caráter mais dramático, quando as operações são realizadas visando mais ao interesse geral do grupo e sacrificando os interesses daqueles que participam das sociedades individualmente consideradas. ${ }^{542}$

Conforme explica LEÃES, nas operações de incorporação entre sociedades sob controle comum, o equilíbrio de interesses obtido mediante a determinação minuciosa do processo de incorporação sofre uma turbação na sua equivalência, pois os termos da equação se alteram diante da introdução do interesse da controladora no seio da sociedade controlada. Quando se fala em controle, sabemos que aludimos a uma instância que transcende as prerrogativas da maioria acionária exercidas dentro da assembleia, instaurando-se, portanto, uma unidade de comando entre as sociedades que estão sob controle comum. Em outras palavras, desapareceriam as duas vontades sociais que se manifestam para aprovar as operações de incorporação ${ }^{543}$ e, por essa razão, há quem fale em autocontratação ou a clássica self dealing transaction dos americanos, ${ }^{544-545}$

Na verdade, a necessidade de equilíbrio entre os interesses envolvidos se insere em um contexto mais amplo de busca por um sistema societário mais eficiente, no qual a possibilidade de extração de benefícios particulares pelo controlador seja cerceada. Embora não haja uma definição legal precisa, entende-se pela expressão genérica "benefícios particulares de controle" todos os benefícios usufruídos pelo controlador e não partilhados pelos minoritários de forma proporcional, decorrentes do problema de agência

542 Cf. M. M. GUIRÃo, Fusión de Sociedades... cit., p. 43. Nesses casos, o contrato de fusão tem sido acoimado de nulo com base na teoria do abuso de direito, do desvio ou abuso de poder e até mesmo de autocontratação.

543 L. G. P. B. LEÃES, Incorporação de companhia controlada... cit., p. 93.

544 Vide ASQUINI apud M. M. GUIRÃO, Fusión de Sociedades... cit., p. 43, nota 19. Também enxergam como autocontratação N. EIZIRIK, A Lei das S/A comentada... cit., p. 402; P. C. ARAGÃO; M. M. MAVIGNIER DE LIMA, Incorporação de controlada... cit., p. 348; e V. BRUDNEY; M. A. CHIRELSTEIN, Fair Shares... cit., p. 298. No mesmo sentido, F. K. COMPARATO, citado no voto de Luiz Leonardo Cantidiano no âmbito do Processo CVM n. RJ 2003/12770, rel. SEP, j. 26.12.2003, diz que: "em se tratando de incorporação de controlada por controladora, é preciso afastar a ideia de que os termos e condições do negócio possam ser definidos, livremente, pelas partes, como se estas negociassem com autonomia". No mesmo processo, o voto do presidente Luiz Leonardo Cantidiano cita o Memo/CVM/SEP/GEA-4/030/03 dizendo que "a incorporação das ações dos minoritários de companhia controlada caracteriza-se como sendo, na sua essência, uma operação onde o acionista controlador está deliberando consigo mesmo [...]. Diante disso, a incorporação de ações de companhia controlada impõe ao controlador procedimento rigoroso na justa avaliação dos patrimônios e na equânime relação de troca das ações".

545 No entanto, a figura do autocontrato, propriamente dito, seria impossível em vista da duplicidade das declarações de vontade nos negócios bilaterias (cf. L. G. P. B. LEÃES, Incorporação de companhia controlada... cit., p. 93). 
existente entre controladores e não controladores. ${ }^{546}$ Nesse contexto, as operações de incorporação entre sociedades sob controle comum são justamente uma das maneiras possíveis de extração de benefícios particulares pelo acionista controlador por meio da aprovação de tais operações em detrimento dos minoritários, principalmente mediante diluição de tais acionistas em decorrência de uma relação de troca ruim. ${ }^{547}$

Além disso, outros fatores que justificam a incidência de uma regulação especial nesses casos são (i) a concentração das participações acionárias em uma única sociedade, o que pode diminuir ainda mais a influência dos acionistas minoritários, e (ii) o reflexo do poder de controle e da influência do acionista controlador na administração das sociedades, as quais são muitas vezes constituídas pelas mesmas pessoas e que acabam não tendo incentivos para negociar os termos da operação.

Não por outra razão a CVM já declarou que de todas as operações frequentes no mercado brasileiro, as incorporações de controladas são, sem sombra de dúvida, as mais problemáticas. De acordo com a autarquia, esse caráter problemático se deve a uma combinação dos seguintes fatores: (i) possibilidade de prejuízos significativos para os minoritários, pois, como essas operações normalmente envolvem todo o patrimônio da empresa, qualquer desequilíbrio na relação de troca das ações pode trazer perdas consideráveis para os acionistas; (ii) caráter coercitivo da operação, pois o controlador

546 R. J. GILSON; J. N. GORDON, Controlling Controlling Shareholders, Columbia Law and Economics Working Paper N. 228, disponível em <http://papers.ssrn.com/sol3/papers.cfm?abstract_id=417181>, acesso em: 15 nov. 2013, p. 2; e K. HOEFSTETTER, One size does not fit all... cit., p. 15.

547 Vide E. S. MUNHOZ, Desafios do direito societário na companhia aberta... cit., p. 143. Uma das maneiras identificadas de extração de benefícios particulares em operações de incorporação relaciona-se com as chamadas freeze out transactions, nas quais os minoritários recebem ações por um valor de mercado que reflete o desconto equivalente aos benefícios particulares de controle (R. J. GILSON; J. N. GORDON, Controlling Controlling Shareholders... cit., p. 13). Freeze out transactions podem tomar duas formas: tender offers ou fusões e incorporações, sendo que ambas devem ser avaliadas cuidadosamente porque envolvem o risco de os minoritários se desfazerem de suas ações por uma contraprestação muito baixa. No caso das fusões ou incorporações, o risco é ainda maior dada a coercibilidade da decisão do controlador sobre os minoritários. Especificamente, a aprovação de tais operações pode possibilitar aquilo que se denominou extração de benefícios particulares de controle externos, ou seja, aqueles obtidos pelo controlador na qualidade de acionista da companhia por meio de sua atuação na assembleia, em oposição aos benefícios particulares de controle internos, que, de modo geral, caracterizam-se pela utilização dos ativos da companhia em benefício do controlador por meio da gestão por ele conduzida na companhia. Em geral, a forma de lidar com a extração de benefícios privados externos está ligada à elaboração de regras aplicáveis às deliberações tomadas pela companhia, seja de modo procedimental, mediante estabelecimento de regras e procedimentos formais para determinada deliberação, ou material, permitindo-se a contestação pelos minoritários se ficar provado que as decisões em assembleia foram arbitrárias ou feriram o princípio geral de tratamento igualitário dos acionistas (cf. K. HOEFSTETTER, One size does not fit all... cit., p. 15 e 29). 
pode votar nessas operações, ainda que figure como contraparte na operação; (iii) insuficiência do direito de recesso como mecanismo de tutela; (iv) incapacidade do mercado de reprimir eventuais abusos de poder de controle nessas operações, pois como os ganhos a serem obtidos são elevados, podem compensar o prejuízo reputacional sofrido pelos controladores; e (v) dificuldade para avaliar a equitatividade das relações de troca propostas, devido ao caráter parcialmente subjetivo das avaliações de empresas. ${ }^{548}$

A junção de todos os fatores acima pode gerar incentivos econômicos para que se fixem relações de troca injustas que serão posteriormente aprovadas unilateralmente pelo controlador. Dessa maneira, a justificação da operação deve ser ainda mais rigorosa, pois o risco de expropriação dos sócios minoritários é fundamentalmente maior. É preciso, portanto, assegurar que a operação corresponda efetivamente ao interesse social e seja realizada sem prejuízo aos minoritários. ${ }^{549}$ Por essa razão, é comum que as legislações adotem procedimentos especiais para regular operações envolvendo sociedades sob controle comum.

Em Delaware, por exemplo, tais operações passam por um exame mais severo do que operações entre partes independentes. Em vez do standard do business judgment rule, aplicável em regra à análise dos atos negociais, tais operações são sujeitas ao entire fairness review. Essa doutrina foi criada a partir do famoso caso Weinberger v. UOP 550 cuja decisão foi fundamental para definir os parâmetros aplicáveis às operações realizadas entre sociedades sob controle comum, as quais, mais do que atender ao business judgment rule, deverão ser entirely fair para os acionistas minoritários. ${ }^{551}$

548 Vide memorando apresentado pelo Diretor Marcos Pinto que deu origem ao PO CVM 35 preparado em 01.09.2008.

549 Cf. A. PÉrez Troya, la determinación del tipo de canje... cit., p. 67. No mesmo sentido, W. BULGARELLI, Fusões, Incorporações... cit., p. 164.

550 Vide Weinberger v. UOP, Inc., 457 A.2d 701 (Del. 1983). O caso trata da incorporação da subsidiária UOP pela Signal, sua acionista controladora com 50,5\% do capital social, em que os acionistas minoritários receberiam dinheiro como contraprestação em vez de ações da Signal (cash out merger). Referida incorporação foi considerada inválida (not fair) pelas cortes em função da conduta dos seus administradores, dando origem ao famoso precedente.

551 É verdade que no julgamento do caso Singer v. Magnavox Co. (380 A.2d 969 (Del. 1977) a Suprema Corte de Delaware já havia decidido que a previsão legal do direito de recesso não afastava os deveres fiduciários dos administradores nas incorporações de controladas, deixando claro que os administradores devem negociar termos e condições de incorporação que sejam entirely fair para os acionistas minoritários. Em seguida, no caso Weinberger v. UOP, Inc., a Suprema Corte detalhou o que configura uma operação como entirely fair. 
Sob essa análise, a companhia, seu controlador e administradores têm o ônus de comprovar em juízo que a operação encerra, a um só tempo, uma negociação justa (fair dealing) e um preço justo (fair price). ${ }^{552} \mathrm{~A}$ análise do preço justo compreende a contraprestação paga pelo controlador pela compra das ações dos minoritários (i.e., a quantidade de dinheiro, títulos ou valores mobiliários pagos aos acionistas, incluindo as contraprestações econômicas e financeiras oferecidas e todos os outros fatores relevantes como ativos, valor de mercado, resultados futuros e todos os outros elementos que possam afetar o valor de uma ação da companhia) e tem impacto direto no valor dos appraisal rights existentes sob direito norte-americano. Já a análise da negociação justa traduz-se em averiguar quando a operação foi realizada e como foi estruturada e negociada. ${ }^{553}$

Não obstante, a adoção de certas medidas procedimentais pode inverter o ônus da prova, que passará a ser do acionista que desejar questionar a operação. Entre tais medidas, destacamos a criação, aprovação e recomendação da operação por um comitê independente, que tenha autoridade para negociar os termos da operação, principalmente o preço a ser oferecido aos demais acionistas, e cujo papel seja defender agressivamente os interesses dos minoritários e assegurar a imparcialidade dos termos da operação. ${ }^{554}$

A ideia do comitê independente foi sugerida pela primeira vez justamente em nota de rodapé da decisão do caso Weinberger $v$. UOP, quando a corte sugeriu que poderia ter sido demonstrado o fair dealing se um comitê de diretores independentes tivesse negociado os termos da operação com os administradores da sociedade controladora. ${ }^{555}$

552 Cf. J. H. CHOPER; J. C. COFFEe, JR.; R. J. GILSON, Cases... cit., p. 1071-1092; e G. SUBRAMANIAN, Fixing freezeouts, The Yale Law Journal, v. 115:2, disponível em <http://www.yalelawjournal.org/pdf/115-1/Subramanian.pdf>, acesso em: 12 jun. 2012, p. 11.

553 No caso em questão, a corte focou sua análise mais no que consistiria o fair dealing test, pois a imparcialidade do processo é, segundo a corte, a melhor garantia de que o preço final seja justo. Também os autores americanos reconhecem que é mais difícil estabelecer que o preço oferecido era justo do que determinar que a operação foi fruto de uma negociação justa (cf. M. J. MCGUINNESS; T. REHBOCK, Going-Private Transactions... cit., p. 4).

554 Cf. memorando do PO CVM 35 preparado em 01.09.2008. Tipicamente, os poderes atribuídos ao comitê especial incluem a autoridade de (i) rever, avaliar e negociar os termos e as condições da operação e fazer uma recomendação ao conselho de administração em relação a uma operação específica; (ii) contratar assessores legais e financeiros independentes a expensas da companhia; e (iii) tomar qualquer outra medida que julgue necessário para desempenhar suas funções (cf. M. J. MCGUINNESS; T. REHBOCK, Going-Private Transactions... cit., p. 5-7).

555 Nos termos da nota de rodapé: "Although perfection is not possible, or expected, the result here could have been entirely different if UOP had appointed an independent negotiating committee of its outside directors to deal with Signal at arm's length. Since fairness in this context can be equated to conduct by a theoretical, wholly independent, board of directors acting upon the matter before them, it is 
Desde então, a utilização do comitê independente tem sido cada vez mais frequente em operações entre sociedade e sua acionista controladora nos Estados Unidos. ${ }^{556}$

Ao criar um comitê para negociar a operação cujos membros sejam compostos de administradores independentes do acionista controlador, busca-se aproximar a negociação do que ocorreria se as partes fossem independentes, entendendo-se que essa independência é a melhor maneira de garantir a comutatividade da relação de troca e dos demais termos da operação na linha do que já vimos neste trabalho. ${ }^{557}$ Por isso, essa prática não apenas inverte o ônus da prova em possíveis ações questionando a justiça da operação, como também fortalece os argumentos do acionista controlador de que o preço oferecido era justo e que foi resultado de uma negociação justa.

Um segundo sistema também sugerido pela jurisprudência americana no contexto das operações de freezeout nos últimos anos é a obtenção da aprovação da maioria dos acionistas que não estão em ambos os lados da operação, chamado de majority of minority condition. ${ }^{558}$ A aprovação pela maioria da minoria é relevante e eficaz por duas razões: a primeira porque promove uma verificação sobre os trabalhos do comitê independente; a segunda porque promove uma verificação de mercado à operação já que a existência de ofertas melhores faria com que os minoritários não aprovassem a operação. ${ }^{559}$ Nesses casos, caso um acionista não controlador recorra ao Judiciário questionando os termos de uma operação que foi aprovada pela maioria dos acionistas não controladores caberá a ele o ônus de provar que a operação não foi negociada por preço justo e de maneira adequada. Ainda, se uma operação tiver sido negociada por comitê independente e cumulativamente aprovada pela maioria da minoria é considerado que ela estaria muito

unfortunate that this course apparently was neither considered nor pursued. Particularly in a parentsubsidiary context, a showing that the action taken was as though each of the contending parties had in fact exerted its bargaining power against the other at arm's length is strong evidence that the transaction meets the test of fairness" (transcrita em G. SUBRAMANIAN, Fixing freezeouts cit., p. 12).

556 Cf. G. Subramanian, Fixing freezeouts cit., p. 12; M. B. PENTEADO, The efficacy of intra-corporate approvals in negotiated mergers between controlling shareholder and its corporation under Delaware and Brazilian law, Revista de Direito Mercantil Industrial, Econômico e Financeiro, n. 143, São Paulo: Malheiros, 2006, p. 82; e C. M. TOMAZELlA, Proteção de acionistas e credores... cit., p. 99.

557 Vide C. M. TOMAZELla, Proteção de acionistas... cit., p. 97-98.

558 Cf. M. J. MCGUINNESS; T. REHBOCK, Going-Private Transactions... cit., p. 4-5.

559 Cf. G. Subramanian, Fixing freezeouts cit., p. 53. 
próxima daquelas realizadas por partes independentes e, por isso, sujeita ao escrutínio da business judgment rule. ${ }^{560}$

No direito europeu, por sua vez, a regulação de tais operações se dá pela facilitação do direito de retirada, principalmente quando a incorporadora detiver mais de 90\% do capital social da incorporada, em vez de uma regulação minuciosa da relação de troca. 561

Na legislação brasileira, por sua vez, foi criada uma regulação especial para conferir maior proteção aos acionistas minoritários consubstanciada fundamentalmente no art. 264 da Lei das S.A. que diz respeito a dois tópicos: (i) o critério de avaliação dos patrimônios líquidos das sociedades participantes; e (ii) a relação de troca das ações. Além disso, o art. 245 da Lei das S.A. rege a conduta dos administradores nesses casos com o intuito de garantir que uma sociedade não seja favorecida em detrimento da outra.

\subsubsection{Relação de Substituição de Ações e Avaliação dos Patrimônios}

Já abordamos o fato de que nas operações de incorporação entre sociedades independentes não há nenhuma exigência legal sobre os critérios de determinação da relação de troca ou de avaliação do patrimônio da sociedade incorporada, tampouco há obrigatoriedade de avaliação do patrimônio da incorporadora. Como se viu, parte-se do princípio de que tais critérios e parâmetros foram devidamente negociados pelos representantes das sociedades envolvidas na operação de modo que se alcance a melhor relação de troca possível que atenda aos interesses sociais das respectivas companhias.

560 Embora não haja ainda um posicionamento oficial por parte da Suprema Corte de Delaware sobre a possibilidade de afastar o entire fairness review nesses casos, algumas decisões já sinalizam nesse sentido: vide In re Cox Communications, Inc. Shareholders Litigation; In re CNX Gas Corporation Shareholders Litigation; e In RE MFW Shareholders Litigation. Vide também C. M. TOMAZELLA, Proteção de acionistas... cit., p. 107. Importante notar que a adoção de um comitê independente ou obtenção da aprovação da maioria da minoria, isoladamente, apenas invertem o ônus da prova, mas não fazem com que a operação passe a ser analisada pela business judgment rule (cf. G. SUBRAMANIAN, Fixing freezeouts cit., p. 16).

561 Sobre os diferentes tratamentos do direito de retirada em operações entre controladora e controlada nos países europeus, vide C. M. TOMAZELlA, Proteção de acionistas... cit., p. 88-89. Vide também art. 28. ${ }^{\circ}$ da Diretiva 2011/35. 
No entanto, tratando-se de incorporação entre sociedades sob controle comum, o art. 264 da Lei das S.A. impõe um procedimento adicional a ser seguido. ${ }^{562}$ Nos termos do referido artigo, os dois patrimônios líquidos - tanto da incorporadora quanto da incorporada - devem ser avaliados a preços de mercado na mesma data, devendo constar na justificação, além das informações previstas nos arts. 224 e 225 da Lei das S.A., o cálculo das relações de substituição das ações dos acionistas das sociedades com base na avaliação comparativa dos dois patrimônios das sociedades envolvidas, determinados por três peritos ou empresa especializada (ou, nos casos de companhia aberta, apenas por empresa especializada) segundo os mesmos critérios e na mesma data. ${ }^{563}$

O critério do patrimônio líquido a preços de mercado, como vimos, busca simular o valor da companhia que seria obtido em uma liquidação ordenada, considerando cada item do ativo e do passivo da companhia mensurado, individualmente, por seu possível valor de venda ou reposição. Hoje, no entanto, sabe-se que se trata de uma das avaliações mais caras e mais demoradas de serem realizadas, além de não ser um critério que necessariamente assegure o valor justo da companhia que poderia ser apurado em uma avaliação econômica. Por essa razão, a Lei n. 10.303/2001 alterou a Lei das S.A. para possibilitar a utilização por companhias abertas de outro critério que seja aceito pela CVM para determinação da relação de troca. Essa prerrogativa levou algum tempo até ser exercida pela CVM, mas, atualmente, ela tem admitido a adoção de outros critérios para

562 Lei das S.A.: “Art. 264. Na incorporação, pela controladora, de companhia controlada, a justificação, apresentada à assembleia geral da controlada, deverá conter, além das informações previstas nos arts. 224 e 225, o cálculo das relações de substituição das ações dos acionistas não controladores da controlada com base no valor do patrimônio líquido das ações da controladora e da controlada, avaliados os dois patrimônios segundo os mesmos critérios e na mesma data, a preços de mercado, ou com base em outro critério aceito pela Comissão de Valores Mobiliários, no caso de companhias abertas.

$\S$ 1. $^{\circ}$ A avaliação dos dois patrimônios será feita por 3 (três) peritos ou empresa especializada e, no caso de companhias abertas, por empresa especializada.

§ 2. ${ }^{\circ}$ Para efeito da comparação referida neste artigo, as ações do capital da controlada de propriedade da controladora serão avaliadas, no patrimônio desta, em conformidade com o disposto no caput.

$\S 3$. $^{\circ}$ Se as relações de substituição das ações dos acionistas não controladores, previstas no protocolo da incorporação, forem menos vantajosas que as resultantes da comparação prevista neste artigo, os acionistas dissidentes da deliberação da assembléia-geral da controlada que aprovar a operação, observado o disposto nos arts. 137, II, e 230, poderão optar entre o valor de reembolso fixado nos termos do art. 45 e o valor do patrimônio líquido a preços de mercado.

§ 4..$^{\circ}$ Aplicam-se as normas previstas neste artigo à incorporação de controladora por sua controlada, à fusão de companhia controladora com a controlada, à incorporação de ações de companhia controlada ou controladora, à incorporação, fusão e incorporação de ações de sociedades sob controle comum.

$\S 5 .^{\circ} \mathrm{O}$ disposto neste artigo não se aplica no caso de as ações do capital da controlada terem sido adquiridas no pregão da bolsa de valores ou mediante oferta pública nos termos dos artigos 257 a 263 ". 
avaliar os patrimônios das empresas envolvidas, principalmente o fluxo de caixa descontado. ${ }^{564}$

Realizada a avaliação determinada pelo art. 264, se as bases da operação aprovada pela controladora forem menos vantajosas para os acionistas minoritários da controlada do que a relação de troca determinada por força do art. 264, os acionistas dissidentes que estiverem intitulados a exercer seu direito de retirada poderão optar pelo reembolso das suas ações pelo valor previsto no art. 45 da Lei das S.A. (em geral, valor patrimonial) ou pelo valor calculado com base no valor de patrimônio líquido contábil a preços de mercado (ou conforme outro critério aceito pela CVM), o que for mais vantajoso. Em resumo, portanto, dois cálculos deverão ser apresentados aos acionistas das companhias envolvidas para comparação: aquele proposto pela administração da companhia de acordo com os critérios por ela eleitos e o cálculo da relação de troca segundo o valor patrimonial das ações a preços de mercado ou conforme outro critério que venha a ser eleito pela CVM. ${ }^{565}$

Essa alternativa para o cálculo do valor do reembolso das ações dos acionistas dissidentes, calcada sobre normas especiais a respeito do direito de retirada do acionista, é, na verdade, o principal meio de proteção dos minoritários em operações envolvendo sociedades sob controle comum. ${ }^{566-567} \mathrm{O}$ pagamento de um valor mais alto a título de reembolso pode, inclusive, fazer com que a companhia e, de maneira indireta, também o

564 Cf. Processo CVM n. RJ 2009/7847, rel. SEP, j. 01.09.2009 e Processo CVM n. RJ 2006/3160, rel. SEP, j. 18 e 30.05.06. Na maioria das vezes, no entanto, o critério do patrimônio líquido a preços de mercado é dispensado quando não existem minoritários significativos a serem protegidos, casos em que tem-se aceitado até mesmo a utilização do critério contábil, conforme Processo CVM n. RJ 2005/2597, rel. SEP, j. 03.05.05; Processo CVM n. RJ 2006/7365, rel. Dir. Sergio Weguelin, j. 22.11.05; Processo CVM n. RJ 2007/3465, rel. Dir. Eli Loria, j. 29.05.07; Processo CVM n. RJ 2009/6414, rel. SEP, j. 29.09.09; Processo CVM n. RJ 2007/15051, rel. SEP, j. 22.01.2008 e Processo CVM n. RJ 2010/16879, rel. SEP, j. 28.12.2010. O Edital de Audiência Pública para reforma da ICVM 319 propõe, inclusive, que sejam desde já aceitos os critérios de fluxo de caixa descontado e múltiplos de mercado em substituição ao critério do patrimônio líquido a preços de mercado previsto no art. 264, dispensando a necessidade de pré-aprovação da autarquia para utilização de tais critérios, desde que nenhum deles já tenha sido utilizado para a determinação da efetiva relação de troca.

565 Cf. A. S. LAZZAReSChi Neto, Lei das Sociedades por Ações anotada, 3. ed., São Paulo: Saraiva, 2010, p. 638.

566 Cf. A. LAMY Filho; J. L. BUlhões Pedreira (Coord.), Direito das companhias, v. 2, cit., p. 2048; P. C. ARAGÃo; M. M. MAVIGNIER DE LIMA, Incorporação de controlada... cit., p. 100-101; e C. M. TOMAZElla, Proteção de acionistas e credores... cit., p. 89.

567 Algumas críticas ao recesso previsto na Lei das S.A. estão mencionadas no item 3.2.3 abaixo, tendo sido consideradas justamente para a elaboração do PO CVM 35 como meio alternativo de proteção dos acionistas minoritários. 
controlador, sejam mais onerados se aprovadas operações impopulares, de modo que, nesse sentido, pode haver um incentivo para aprovação de uma relação de troca próxima aos preços de mercado. ${ }^{568}$

Assim, o art. 264 da Lei das S.A. exerce uma dupla função: (i) oferecer aos acionistas não controladores um mecanismo adicional de proteção ao adicionar a avaliação da incorporadora como um novo elemento nas informações que devem ser divulgadas aos acionistas com o intuito de que esses acionistas possam avaliar a razoabilidade da relação de troca contratada no protocolo de incorporação; e (ii) servir como critério alternativo para o cálculo do valor de reembolso aos acionistas dissidentes. ${ }^{569}$

Importante notar, no entanto, que a Lei das S.A. não exige que a relação de troca seja efetivamente ajustada com base no previsto no art. 264 da Lei das S.A., a qual continua podendo ser determinada por outro critério eleito pela administração de acordo com o princípio da liberdade contratual que permanece vigente mesmo nas operações entre partes independentes. ${ }^{570} \mathrm{O}$ art. 264 da Lei das S.A. trata, portanto, de uma relação de troca teórica, apenas para fins informativos, que possibilita ao minoritário tê-la como referência para compará-la com aquela proposta pela administração da companhia de modo que demonstre a sua equitatividade. ${ }^{571}$ Assim, a lei societária optou por oferecer uma proteção adicional aos acionistas minoritários da sociedade incorporada apenas em termos informacionais, sem que, entretanto, fosse excluído o direito das partes de determinar o critério de avaliação do patrimônio a ser incorporado e de determinar a relação de troca conforme seu entendimento. ${ }^{572}$

568 Cf. C. M. TOMAZElla, Proteção de acionistas e credores... cit., p. 94.

569 Cf. C. M. TOMAZELla, Proteção de acionistas e credores... cit., p. 90. Vide também A. LAMY FILHO; J. L. BUlHÕES PEDREIRA (Coord.), Direito das companhias, v. 2, cit., p. 2048; e N. EIZIRIK, Temas de direito societário... cit., p. 322-324.

570 Cf. N. EIZIRIK, A Lei das S/A comentada... cit., p. 402; P. C. ARAGÃO; M. M. MAVIGNIER DE LiMA, Incorporação de controlada... cit., p. 356; L. L. CANTIDIANO, Reforma da Lei das S.A. comentada, Rio de Janeiro: Renovar, 2002.

571 N. EIZIRIK, Temas de direito societário... cit., p. 385. No mesmo sentido, vide, por exemplo, Processo CVM n. RJ 2004/5914, rel. SEP, j. 25.10.2004; Processo CVM n. RJ 2009/7847, rel. SEP, j. 01.09.2009; Processo CVM n. RJ 2007/11573, j. 04.10.2007 e Processo CVM n. RJ 2001/9986, rel. SEP, j. 24.09.2001.

572 Cf. D. KALANSKY, Incorporação de ações... cit., p. 54. No mesmo sentido, vide PAS CVM n. 24/04, rel. Dir. Eli Loria, j. 31.07.2007, ao afirmar que "na hipótese de incorporação de companhia controlada pela controladora, o legislador, tendo em vista que quem aprova a operação é o mesmo acionista controlador, houve por bem oferecer aos acionistas minoritários da controlada uma proteção adicional para assegurar 
No entanto, o fato de o art. 264 da Lei das S.A. se referir a uma relação de troca meramente informacional em nada altera o entendimento discutido neste trabalho de que a validade das operações de incorporação deve, em qualquer caso, atender ao interesse social de ambas as companhias e que, portanto, a concretização de tais operações deve demonstrar uma maximização da rentabilidade dos acionistas de ambas as sociedades envolvidas na operação em virtude dos benefícios esperados com a incorporação. É certo que os benefícios de operações de incorporação entre partes independentes são geralmente superiores àqueles havidos entre partes relacionadas, ${ }^{573}$ mas mesmo nesse último caso tais benefícios devem ser também verificados. ${ }^{574}$

É bem verdade que o critério adicional estabelecido pelo art. 264 da Lei das S.A. baseia-se em uma relação de troca pura, i.e., aquela determinada considerando apenas a proporção dos patrimônios das sociedades separadamente. Tal fato poderia dar a entender que não foram considerados pela Lei das S.A. os eventuais benefícios gerados pela operação para determinação da relação de troca nem a divisão de tais benefícios entre as sociedades como requisito de validade de tais operações conforme defendemos ao longo deste trabalho. Essa interpretação, no entanto, não nos parece correta, pois a existência de uma relação de troca pura apurada nos termos do art. 264 não significa que se está abrindo mão da necessidade da existência de benefícios como modo de justificar a validade de tais operações. Na verdade, seguida a recomendação do art. 264 da Lei das S.A., pressupõe-se que as sociedades participariam dos ganhos futuros da operação de acordo com a proporção dos seus patrimônios considerados de maneira separada, o que, como vimos, não é necessariamente equivocado. Corroborando esse entendimento, alguns autores afirmam que, nos casos de fusões ou incorporações entre sociedade sob controle comum,

que a relação de troca das ações se dê da forma mais equitativa possível. Ou seja, o valor da relação de substituição das ações pode ser fixado livremente no Protocolo, desde que se apresente aos acionistas, para fins de comparação, o laudo do patrimônio líquido a preços de mercado".

573 Cf. V. BRUDNEY, Equal Treatment of Shareholders... cit., p. 1116.

574 Tais benefícios podem advir da eliminação de funções que estejam duplicadas e que só sejam possíveis com a real integração das companhias, de benefícios fiscais decorrentes da incorporação ou, ainda, de uma melhor avaliação do mercado da situação das companhias quando combinadas (cf. V. BRUDNEY; M. A. CHIRELSTEIN, Fair Shares... cit., p. 308). Em outra oportunidade, analisando as operações entre sociedades sob controle comum, V. BRUDNEY menciona que "the possibility that a joint ownership can result in a larger overall value for the two firms than the sum of their values as separate companies makes it impossible to deny that a business purpose may exist (...). Even if synergistic gains (...) were minimal in a particular instance, there is a sound and creditable reason for management to want to reduce to one the number of stockholder constituinces to which it is legally responsible" (A Restatement of Corporate Freezeouts, 87 Yale L. J., 1977-1978, p. 1371). 
os administradores devem, de fato, fixar uma relação de troca que não se distancie demais do valor "puro" da relação de troca. Assim, quando as duas vontades que se confrontam para a formação da operação não são equivalentes e não são autônomas, a determinação da relação de troca deve se pautar no mais possível sobre dados demonstráveis e, consequentemente, a regra fundamental é que a relação de troca seja aquela teórica ou pura, sem ter em conta os diferentes interesses e a força contratual das partes no processo de negociação. ${ }^{575}$ À mesma conclusão chegam V. BRUDNEY e M. A. CHIRELSTEIN ao discutir a forma apropriada de divisão dos ganhos resultantes de operações concluídas entre sociedades sob controle comum. Para os autores, em primeiro lugar, é condição de validade de tais operações que ambas as sociedades participem nos ganhos esperados. Em seguida, continuam os autores afirmando que a correta divisão de tais ganhos não depende, na verdade, de simular uma operação entre partes independentes, o que seria impossível com uma administração única nas duas companhias, e sim de garantir uma divisão dos ganhos de acordo com os valores das companhias antes da conclusão da operação, de modo que a operação seja justa porque garante a todos os acionistas um tratamento igualitário já que será assegurado o mesmo retorno por capital investido. ${ }^{576}$ Concordamos com essa opinião já que, no caso de operações de incorporação entre sociedades sob controle comum, qualquer afastamento de uma relação de troca pura deveria ser ainda mais justificado e detalhado pela administração e pelo controlador haja vista a falta independência entre as partes para se atingir uma relação de troca "negocial" como se tivesse sido negociada entre partes independentes. Não obstante, não descartamos também a possibilidade de que a administração apresente uma justificativa para comprovar por que uma relação de troca diferente da relação de troca "pura" é aplicável ao caso concreto, ainda que essa comprovação tenha que ser mais fundamentada.

Exceção à regra prevista no art. 264 da Lei das S.A. existe caso as ações da controlada tenham sido adquiridas no pregão da bolsa ou mediante oferta pública, hipóteses em que não é exigida a divulgação das relações de substituição a preço de mercado. Essa exceção parte do pressuposto de que as ações da controlada adquiridas nos termos acima já têm um valor bem definido pelo mercado e conhecido pelos acionistas, de modo que o procedimento de avaliação a preços de mercado e as respectivas despesas que

575 Cf. A. VICARI, Gli Azionisti... cit., p. 73-74.

576 Fair Shares... cit., p. 307-322. Vide também V. BRUDNEY, A Restatement of Corporate Freezeouts... cit., p. 1373. Cf. também a decisão do caso Mills v. Electric Auto-Lite Co. no mesmo sentido. 
seriam arcadas pela companhia se tornam dispensáveis. ${ }^{577}$ Além disso, certas vezes os requisitos do art. 264 também são dispensados nas hipóteses em que também há dispensa de aplicação dos demais requisitos da ICVM 319 conforme analisamos no item 3.1 acima, i.e., nos casos expressamente previstos na Deliberação CVM n. 559/2008 ou em que inexistem acionistas minoritários a serem tutelados, em que as participações societárias da incorporada já estão refletidas na incorporadora e que inexiste relação de troca a ser determinada por conta da ausência de entrada de novos acionistas.

Por fim, com o intuito de melhorar o rol de informações posto à disposição dos acionistas, o Edital de Audiência Pública para reforma da ICVM 319 preocupou-se especificamente com a questão das operações entre sociedades sob controle comum exigindo, além do cálculo da relação de troca nos termos do art. 264, a divulgação das seguintes informações: (i) descrição detalhada do processo de negociação da relação de substituição e demais termos e condições da operação; (ii) caso a operação tenha sido precedida de uma aquisição de controle ou a aquisição de participação em bloco de controle, divulgação de análise comparativa da relação de substituição e do preço pago na aquisição de controle e as razões que justificam eventuais diferenças de avaliação nas diferentes operações; (iii) justificativa de por que a relação de substituição é comutativa, com a descrição dos procedimentos e critérios adotados para garantir a comutatividade da operação; (iv) cópia das atas de todas as reuniões do conselho de administração, conselho fiscal e comitês especiais em que a operação foi discutida, incluindo eventuais votos dissidentes; e (v) cópia de estudos, apresentações, relatórios, opiniões, pareceres ou laudos de avaliação das companhias envolvidas na operação utilizados ou postos à disposição da companhia ou do acionista controlador em qualquer etapa da operação.

577 Cf. A. LAMY FILHO; J. L. BUlhões PEDREIRA (Coord.), Direito das companhias, v. 2, cit., p. 2048 ; e R. V. RIBEIRO, Incorporação de companhia controlada... cit., p. 112. Nesses casos, considerando que não é exigido preparar os cálculos da relação de troca determinados pelo art. 264, questiona-se se os acionistas dissidentes poderiam ser reembolsados pelo valor patrimonial de mercado de suas ações ou se deveriam se contentar com a norma genérica do art. 45 da Lei das S.A. CALIXTO SALOMÃo FILHO parece entender que o sobrepreço pago pelo controlador na aquisição do pregão ou oferta pública deve ser necessariamente incluído no valor do reembolso, pois a aquisição de controle seguida de incorporação é hipótese clara de cessão de organização empresarial e, por isso, todos os acionistas deveriam participar em igualdade de condições (F. K. COMPARATO; CALIXTO SALOMÃO FILHO, O poder de controle... cit., p. 117; e CALIXTO SALOMÃo FILHO, O novo direito societário cit., p. 156). No mesmo sentido, há precedentes da CVM manifestando entendimento de que é necessário assegurar a todos os acionistas condições equitativas nesses casos (Processo CVM n. RJ 2003/12770, rel. SEP, j. 26.12.2003). 
De qualquer maneira, é comum haver críticas no sentido de que o art. 264 oferece proteção limitada aos acionistas, pois, embora a divulgação da relação de substituição prevista no art. 264 da Lei das S.A. em comparação com a relação de substituição negociada pela administração possa auxiliar os acionistas a apurar a razoabilidade da operação proposta, a operação poderá ainda ser aprovada pelo controlador, mesmo que em termos prejudiciais ao acionista minoritário. A divulgação serviria apenas para tentar embasar o cumprimento ou não dos deveres fiduciários dos administradores e/ou controlador que celebraram o protocolo de incorporação e aprovaram a operação e para uma eventual melhoria do direito de recesso dos minoritários caso seja aplicável. De fato, o art. 264, combinado com uma legislação que permite ampla margem de negociação na relação de troca, não alcança os dois principais problemas das operações de incorporação entre sociedades sob controle comum, que são a possibilidade de aprovação pelo controlador nas assembleias e a influência de tal acionista na administração das sociedades envolvidas, ${ }^{578}$ além de resolver parcialmente a insuficiência do direito de recesso previsto na Lei das S.A. Foram justamente as críticas à limitação do art. 264 como mecanismo de proteção aos minoritários que levaram a CVM a formular o PO CVM 35, que discutiremos no item 3.2.3 a seguir.

\subsubsection{Deveres Fiduciários da Administração}

A falta de independência da administração das companhias envolvidas é, como dissemos, um dos pontos de atenção em operações de incorporação envolvendo sociedades sob controle comum. Nesse ponto, a CVM já se manifestou declarando que a independência dos administradores em tais operações está de certa maneira comprometida e, por isso, a atuação dos administradores exige uma supervisão mais rigorosa do cumprimento dos deveres fiduciários previstos na Lei das S.A., obrigando-os a adotar procedimentos que garantam sua independência, a transparência e a comutatividade das negociações realizadas com o controlador. ${ }^{579}$

578 Cf. C. M. TOMAZELLA, Proteção de acionistas e credores... cit., p. 93-94 e 96.

579 Vide voto do Diretor Marcos Barbosa Pinto no Processo CVM n. RJ 2007/3453, rel. Dir. Sergio Weguelin, j. 04.03.2008; vide também PAS CVM n. 08/2005, rel. Dir. Eli Loria, j. 12.12.2007. 
Uma primeira questão que surge em vista da possível falta de independência dos administradores é se existe ou não impedimento de que os administradores que ocupam cargos tanto na sociedade controladora como na sociedade controlada participem das deliberações e negociações da incorporação entre sociedade controladora e controlada por força do art. 156 da Lei das S.A. que veda a atuação do administrador em conflito de interesses com a companhia. ${ }^{580}$

Embora haja manifestações a favor do impedimento de tais administradores para participar das discussões e deliberar uma operação de incorporação, essa interpretação parece não prosperar. Em primeiro lugar, porque entendemos que não há um conflito formal que impedisse desde logo a atuação do administrador. ${ }^{581}$ Além disso, há regulação expressa na Lei das S.A. tratando sobre esse ponto nos arts. 245 e 264 que configuram regulação especial sobre a questão, os quais, em nenhum momento, pressupõem o impedimento do administrador com base em conflito de interesses nos termos do art. 156 da Lei das S.A. O art. 245, por exemplo, não proíbe a atuação dos administradores das sociedades envolvidas, mas lhes veda favorecer, em prejuízo da sociedade em que atuam, outra sociedade que esteja sob o controle comum. ${ }^{582}$ Essa é a posição também defendida pela CVM, que entende que o administrador não deve ser excluído do processo decisório, pois não se pode presumir que ele é a longa manus do controlador, pois a própria lei impõe a ele o dever de atuar sempre no interesse da companhia, mesmo quando isso implique contrariar os interesses do acionista que o elegeu. ${ }^{583}$

Superado esse ponto, cabe averiguar como assegurar que os administradores cumpram seus deveres fiduciários com relação à companhia em que atuam mesmo nos casos de operações entre sociedades sob controle comum. Nesse ponto, além dos deveres

580 Conforme interpretação da CVM, o fato de o administrador estar impedido de participar em qualquer operação social em que tiver interesse conflitante com o da companhia não o impediria apenas de votar a operação, mas também de participar em suas negociações em nome da companhia (vide voto de Marcelo Fernandes Trindade no Processo CVM n. RJ 2004/5494, rel. Dir. Wladimir Castelo Branco, j. 16.12.2004; e Processo CVM n. RJ 2007/3453, rel. Dir. Sergio Weguelin, j. 04.03.2008).

581 Cf. E. VAlladẽo A. E N. FrAnÇA, Temas de direito societário... cit., p. 357-358; E. VALlADÃo A. E N. FRANÇA, Conflito de interesses e benefício particular: uma distinção que se impõe definitivamente dirimir, Revista de Direito Mercantil Industrial, Econômico e Financeiro, n. 161/162, São Paulo: Malheiros, 2012, p. 40; e M. V. VON ADAMEK, Responsabilidade civil... cit., p. 163-164.

582 No mesmo sentido, P. C. ARAGÃo entende que o conflito de interesses surge apenas quando o administrador usa sua posição para satisfação de interesse pessoal em contraste com o interesse da companhia (O Parecer de Orientação 35/2008... cit., p. 528).

583 Cf. Processo CVM n. RJ 2007/3453, rel. Dir. Sergio Weguelin, j. 04.03.2008. 
fiduciários dos administradores que já abordamos neste trabalho, os quais continuam plenamente vigentes nos casos de operações entre sociedades sob controle comum, ${ }^{584} \mathrm{o}$ art. 245 da Lei das S.A. assegura a imparcialidade dos órgãos administrativos nos negócios entre sociedades sob controle comum, ${ }^{585}$ obrigando-os a zelar para que as operações observem condições comutativas ou com pagamento compensatório adequado.

Dessa maneira, na existência de um grupo de fato, o administrador não pode consentir com a prática de atos de favorecimento a uma sociedade específica do grupo nem com a prática de operações com outra sociedade que não sejam em condições estritamente comutativas ou que não prevejam o pagamento compensatório adequado. ${ }^{586}$

No contexto das operações de incorporação, as condições comutativas exigidas pelo art. 245 significariam que os administradores devem negociar uma relação de troca equitativa e que reflita o valor de cada uma das sociedades envolvidas, repartindo entre elas os potenciais ganhos obtidos com a operação ${ }^{587}$ e simulando o que existiria em uma operação entre partes independentes. ${ }^{588}$ Além disso, existindo administradores comuns, conviria também que eles buscassem uma evidência cabal de que a relação de troca foi equitativa, por meio da confirmação desse fato por avaliadores que atendam aos padrões de experiência e especialização. 589

Além disso, o art. 245 da Lei das S.A. bem como o art. 156 preveem que o administrador deverá responder pelas perdas e danos causados caso não desempenhe suas atividades de modo que busque o interesse social.

584 Vide nesse sentido texto do PO CVM 35.

585 Lei das S.A.: "Art. 245. Os administradores não podem, em prejuízo da companhia, favorecer sociedade coligada, controladora ou controlada, cumprindo-lhes zelar para que as operações entre as sociedades, se houver, observem condições estritamente comutativas, ou com pagamento compensatório adequado; e respondem perante a companhia pelas perdas e danos resultantes de atos praticados com infração ao disposto neste artigo".

586 Cf. M. V. VON ADAMEK, Responsabilidade civil... cit., p. 157-158.

587 Cf. PO CVM 35. Vide também D. KALANSKY, Incorporação de ações... cit., p. 123).

588 Cf. L. SILVA, O valor justo em incorporação cit., p. 108.

589 Vide P. C. ARAGÃO, O Parecer de Orientação 35/2008... cit., p. 534. 


\subsubsection{Parecer de Orientação CVM n. 35/2008}

Apesar da regulação existente sobre as operações de incorporação entre sociedades sob controle comum prevista nos arts. 264 e 245 da Lei das S.A., a CVM entendeu que era ainda necessário interpretá-la e desenvolvê-la haja vista a insuficiência das medidas protetivas incluídas na nossa legislação.

Como dissemos, o art. 264 não garante a adequação da relação de troca efetivamente escolhida para a operação e a solução via direito de recesso por valor diferenciado também apresenta suas limitações. Segundo a autarquia, o direito de recesso não seria tutela satisfatória dos interesses dos acionistas minoritários em caso de abuso de poder de controle pelas seguintes razões: (i) inaplicabilidade a todos os acionistas, pois segundo o art. 264, § 1. ${ }^{\circ}$, combinado com o art. 137, II, da Lei das S.A., o recesso não é sequer cabível quando as ações da companhia controlada têm alguma liquidez; ${ }^{590}$ (ii) o art. 45 da Lei das S.A. permite que o valor do reembolso seja feito por valor patrimonial, que raramente reflete o valor justo das ações de uma companhia operacional saudável; ${ }^{591}$ (iii) o cálculo do reembolso pelo valor do patrimônio líquido a preços de mercado previsto no art. 264 não reflete o valor justo das ações de uma companhia operacional saudável na maior parte dos casos; ${ }^{592}$ e (iv) ainda que o valor de reembolso seja apurado pelo valor econômico, que seria o critério mais adequado, a estimativa desse valor é feita por avaliadores escolhidos pelo controlador na própria assembleia geral, conforme o art. $45, \S$ 4. ${ }^{\circ}$, da Lei das S.A.

590 Conforme salientado no memorando preparado pela autarquia para introdução do PO CVM 35 que culminou no Edital de Audiência Pública CVM/SDM n. 02, de 2 de junho de 2008, a regra da Lei das S.A. parte do pressuposto de que o acionista não precisa do recesso quando ele pode vender suas ações no mercado. Não se pode esquecer, todavia, que o simples anúncio de uma incorporação altera os preços vigentes no mercado, que tendem a convergir para a relação de troca proposta na operação. Assim, se a relação de troca prevista na incorporação for ruim, o preço das ações cairá automaticamente e o acionista dissidente estaria fadado a vender sua participação com prejuízo.

591 A grande maioria dos estatutos sociais prevê o recesso a valor de livro como determina o $\S 1 .^{\circ}$ do art. 45 da Lei das S.A., embora a lei permita que o estatuto estabeleça o recesso por valor econômico apurado em laudo de avaliação que satisfaça os requisitos do $\S 1 .^{\circ}$ do art. $8 .^{\circ}$ da Lei das S.A. e com as responsabilidades previstas no $\S 6 .^{\circ}$ do mesmo artigo.

592 Como vimos, o valor de patrimônio líquido a mercado reflete o valor da companhia como se houvesse uma liquidação dos ativos. No entanto, nenhum investidor adquire ações de uma companhia considerando que ela entrará em liquidação, e sim que elas continuarão em funcionamento, sendo, portanto, quase irrelevante o benefício da regra trazida pelo art. 264 para apuração do valor de recesso (vide L. SILVA, $O$ valor justo... cit., p. 74-75). 


\title{
Com isso em mente e em vista do risco de que nas operações de incorporação
}

\author{
entre sociedades controladora e controlada ou sob controle comum a relação de troca
}

negociada não seja, de fato, equitativa, a CVM editou em 2008 o PO CVM 35 como meio

de tutela alternativo para tentar garantir a comutatividade em tais operações. ${ }^{593}$

593 Segundo P. C. ARAGÃO, a abrangência das recomendações do PO CVM 35 se limita aos administradores de companhias abertas controladas, sobre as quais a CVM tem competência (cf. O Parecer de Orientação 35/2008... cit., p. 526. Vide também o Relatório de Análise SDM - Audiência Pública 2/2008 publicado pela CVM na época de edição do PO CVM 35). Além desses casos, o PO CVM 35 expressamente menciona ser aplicável para ambas as companhias quando se tratar de sociedades sob controle comum. Embora tenha sido criado para operações de incorporação que envolvam controlador e controlada ou sociedades sob controle comum, muita confusão já foi feita em relação à aplicabilidade de tal parecer também para outras operações. A primeira delas se deu no caso Sadia/Perdigão/BRF Brasil Foods. A operação de reestruturação societária em questão seria realizada em duas etapas de modo que $100 \%$ do capital social da Sadia passasse a ser detido, direta ou indiretamente, pela BRF Brasil Foods. Na primeira etapa, as ações pertencentes aos integrantes do bloco de controle da Sadia foram conferidas ao capital social de uma empresa veículo, a HFF. Ato contínuo, as ações de HFF foram incorporadas pela BRF Brasil Foods, com uma relação de troca de 0,166247 ações da incorporadora BRF Brasil Foods para cada ação ordinária recebida da incorporada HFF. A segunda etapa envolvia a incorporação das ações pertencentes aos minoritários remanescentes da Sadia pela BRF Brasil Foods a uma relação de 0,132998 ações da BRF Brasil Foods para cada ação ordinária ou preferencial de emissão da Sadia entregue pelos minoritários. Importante observar, que, em função da incorporação de ações da HFF ocorrida na primeira etapa, no segundo momento da operação em que houve a incorporação das ações dos minoritários da Sadia, a BRF Brasil Foods era controladora indireta da Sadia, o que veio a levantar a discussão sobre a aplicabilidade ou não do PO CVM 35 para essa operação. As companhias argumentaram que o PO CVM 35 não seria aplicável à segunda etapa da operação - independentemente da relação de controle entre a BRF Brasil Foods e a Sadia - porque as relações de troca de toda a operação, incluindo a primeira e a segunda etapa, foram negociadas e estabelecidas mediante negociação quando as sociedades ainda eram absolutamente independentes. No entanto, analisando essa operação, o colegiado da CVM entendeu que as disposições do PO CVM 35 eram aplicáveis à segunda etapa da operação, uma vez que, nesse momento, já havia relação de controle entre as duas companhias (cf. Manifestação de entendimento sobre aplicação do Parecer de Orientação n. 35/expedido pela autarquia em 27.05.2009). Fica claro, portanto, que, sob esse aspecto, a autarquia enxergou as diferentes etapas da operação de modo individual e não como parte de uma única operação. Esse equívoco foi devidamente apontado por D. KALANSKY, que deixa claro que o PO CVM 35 não deveria ter sido aplicado a esse caso uma vez que as relações de substituição de ações das companhias foram negociadas num momento em que suas administrações eram absolutamente independentes (Incorporação de ações... cit., p. 254). No mesmo sentido, vide E. F. DE PONTES, Incorporação de ações no direito brasileiro... cit., p. 84. O contrassenso cometido pela autarquia torna-se ainda maior quando o colegiado, ao julgar o processo em função da existência de uma relação de troca diferenciada entre controladores e minoritários (o que será objeto de estudo mais adiante neste trabalho), reconheceu a existência de uma única operação em duas etapas, decidindo, de certa forma, em sentido contraditório àquilo que havia manifestado no comunicado anterior. $\mathrm{O}$ voto do diretor Marcos Pinto no processo é claríssimo ao dizer que "na prática, essas duas incorporações configuram uma única operação, por meio da qual Perdigão e Sadia combinarão seus negócios e suas bases acionárias. Ambas as incorporações foram objeto de um único acordo de associação, negociado entre os administradores e controladores das duas companhias. É evidente, portanto, que elas devem ser apreciadas em conjunto, seja do ponto de vista econômico, seja do ponto de vista jurídico". Vemos, assim, explícita contradição no posicionamento da autarquia que, para fins de aplicação do PO CVM 35, entendeu haver operações distintas, assumindo em seguida a existência de uma única operação em várias etapas, o que tornaria inviável de pronto a aplicação do PO CVM 35 dado que as companhias eram independentes no início da operação. O imbróglio cometido pela autarquia no caso acima relatado fez com que a administração de outras companhias optassem por seguir as regras do PO CVM 35 mesmo quando elas seriam absolutamente inaplicáveis por se tratar de operações entre partes independentes. É o caso, por exemplo, 
Referido parecer de orientação interpreta e tenta dar concretude aos deveres fiduciários impostos pelos arts. 153, 154, 155 e 245 da Lei das S.A. aos administradores de tais sociedades, ${ }^{594}$ estabelecendo procedimentos adicionais (e não vinculantes) àqueles previstos na legislação com o intuito de garantir uma relação de troca equitativa por meio da independência dos administradores e da maior transparência e divulgação em relação às informações e aos dados das operações propostas.

O PO CVM 35 foi criado com base na doutrina americana gerada a partir do famoso caso Weinberger $v$. UOP como esclarece o próprio memorando preparado pelo então diretor da CVM, Marcos Pinto, na qualidade de relator da proposta do Parecer de Orientação posteriormente convertido no Edital de Audiência Pública CVM/SDM n. 02, de 2 de junho de 2008. Nesse sentido, a principal recomendação do PO CVM 35 para garantir que a relação de troca e demais condições da operação sejam negociadas de maneira independente e efetiva é a criação de um comitê independente para negociar os termos e as condições do protocolo em nome das companhias envolvidas na operação. Replicando o direito americano, segundo o parecer, o processo de negociação imparcial deve envolver os seguintes aspectos: (i) constituição de um comitê independente para aprovar as incorporações de controladas; (ii) delegação de amplos poderes ao comitê para efetivamente negociar os termos da incorporação, podendo, inclusive, recusá-la; (iii) obrigatoriedade de divulgação pelos administradores das companhias envolvidas de todas as informações disponíveis para que o comitê independente desempenhe sua função; (iv) disponibilização de assessoria jurídica e financeira independente, remunerada pela companhia; e (v) condução das negociações de maneira diligente. ${ }^{595}$

da operação de incorporação de ações da Aracruz Celulose S.A. (Aracruz) pela Votorantim Celulose e Papel S.A. (VCP), em que as companhias adotaram espontaneamente as regras do PO CVM 35 mesmo tratando-se de partes independentes no momento em que estabeleceram as relações de troca das ações, divulgando esse fato ao mercado.

594 Convém ressaltar que os Pareceres de Orientação emitidos pela CVM não têm, em tese, força vinculante, sendo instrumentos utilizados para dar orientação aos agentes do mercado e aos investidores sobre matéria que cabe à CVM regular bem como para veicular as opiniões da CVM sobre interpretação das Leis n. 6.385/1976 e n. 6.404/1976 no interesse do mercado de capitais (cf. Deliberação CVM n. 1, de 23 de fevereiro de 1978).

595 E. F. DE PONTES faz importantes comentários sobre o processo de incorporação com a utilização de comitês independentes. Para o autor, o procedimento correto seria que a diretoria primeiramente realizasse estudo sobre a operação, estimando os ganhos dela decorrentes e as relações de troca aplicáveis. Tais estudos seriam levados ao conselho de administração e, caso aprovados, o conselho deveria nomear o comitê especial que ficaria incumbido de elaborar a justificação da operação. Para esse fim, os comitês deveriam contratar avaliadores e receber as informações que sustentarão as negociações 
De acordo com o PO CVM 35, o comitê especial independente pode ser composto de uma das seguintes alternativas: (i) apenas por administradores da companhia, em sua maioria independentes; (ii) não administradores da companhia, todos independentes e com notória capacidade técnica, desde que o comitê esteja previsto no estatuto, de acordo com o art. 160 da Lei das S.A.; ou (iii) composto de um administrador escolhido pela maioria do conselho de administração, um conselheiro eleito pelos acionistas não controladores e um terceiro, administrador ou não, escolhido em conjunto pelos outros dois membros. ${ }^{596}$

Com essa solução, a CVM, reconhecendo os desafios enfrentados pelo Judiciário e por ela mesma para avaliar a comutatividade das relações de troca, busca trilhar um caminho intermediário: deixar a determinação da relação de troca nas mãos dos administradores - que estão em melhor posição para negociá-la -, sujeitos, porém, a regras procedimentais que visam a propiciar negociações independentes com o intuito de se alcançar um resultado considerado justo. Assim, o foco da regulação da CVM recai sobre

da relação de troca da operação, bem como deverão estudar se a operação atende aos interesses da companhia. Por fim, devem elaborar parecer recomendando ou não a operação, que será enviado ao conselho de administração. O conselho de administração deveria então convocar assembleia geral para deliberar apenas sobre a justificação da operação nos termos negociados pelo comitê especial, divulgando também a documentação pertinente. Em caso de aprovação da justificação pela assembleia geral, a diretoria seria autorizada a dar início à elaboração do protocolo, quando seria então desfeito o comitê independente. O processo, já saneado pelo comitê independente, seria então retomado pela administração das companhias para elaboração do protocolo, definição de questões de governança e outras questões da operação, sem, no entanto, interferir nos números já aprovados pela assembleia. Por fim, seria necessário novo crivo das assembleias para aprovar a operação em seus termos finais. Dessa maneira, o autor critica o modo como tais operações vêm sendo conduzidas, em que justificação e protocolo se unificam em um único documento, submetido para apreciação da assembleia junto com todos os demais documentos negociados pelo comitê independente ou que deram suporte a tais negociações, tirando dos administradores seus deveres fiduciários e transferindo-os para um comitê $a d$ hoc (Incorporação de ações no direito brasileiro... cit., p. 86-91).

596 A composição dos comitês independentes sugerido pelo PO CVM 35 também não escapa de críticas. Todos os conselheiros independentes têm função equiparada aos membros do conselho de administração e não aos diretores, mas as maneiras de escolha pela assembleia são claras apenas nos primeiro e terceiro casos indicados do item (iii), sendo que temos ainda o agravante de que um conselheiro é eleito independentemente de manifestação da assembleia geral e sem menção a nenhum referendo da assembleia. Outras críticas usualmente feitas decorrem da falta de previsão e regulação de tais assembleias, procedimentos, quóruns, bem como de regras referentes à posse de tais conselheiros. Como se sabe, por força do art. 149 da Lei das S.A., os administradores tomam posse de seus cargos mediante assinatura do termo de posse dentro de 30 dias de sua nomeação. Para os conselheiros independentes, não há termo de posse, livro ou investidura previsto no procedimento, de modo que se presumem investidos no cargo a partir de sua eleição (cf. E. F. DE PONTES, Incorporação de ações no direito brasileiro... cit., p. 87). 
os deveres fiduciários dos administradores em tais operações de modo que prevejam critérios menos subjetivos para auferir o eventual descumprimento de tais deveres. ${ }^{597} 598$

Caso não sejam seguidos os procedimentos previstos no PO CVM 35 referentes aos comitês independentes, a recomendação é que a operação seja condicionada à aprovação da maioria dos acionistas não controladores, inclusive os titulares de ações sem direito a voto ou com voto restrito. ${ }^{599}$

Diversas são as críticas referidas ao PO CVM 35. A primeira delas é que o texto do parecer ido além dos lindes da lei já que a autarquia não teria competência para regular as operações de incorporação da maneira como fez e, mais ainda, para sugerir a restrição do voto do acionista controlador e atribuir competência a comitê independente para negociação da relação de troca. ${ }^{600}$ Além disso, muito se discute sobre a necessidade da edição do referido parecer visto que nossa legislação já haveria trazido os modos de solução do conflito de interesses em operações envolvendo sociedades sob controle comum e de imputação de responsabilidade aos acionistas e administradores que descumprissem seus deveres legais. Conforme já havia sido decidido pela própria autarquia no passado,

[p]ode-se não gostar da solução legal, mas se deve reconhecer que não há espaço, no sistema legal vigente, para construções doutrinárias que queiram conferir direitos adicionais (ou diferenciados) aos acionistas, mesmo quando baseados em uma suposta equidade. A própria lei criou o seu padrão de equidade (relação de substituição ou recesso baseado no

597 Vide nesse sentido C. M. TOMAZELlA, Proteção de acionistas e credores... cit., p. 102.

598 Ao admitir expressamente que o controlador pode votar nas operações de incorporação de companhias controladas e que o cálculo da relação de troca pode ser livremente negociado entre as companhias, coube à CVM se debruçar sobre os deveres fiduciários da administração como modo de regular tais operações. Nesse ponto, compartilhamos com o entendimento da autarquia de que, em nenhum momento, a regulação especial do art. 264 da Lei das S.A. exclui outros mecanismos de proteção do minoritário como a aplicação dos direitos fiduciários da administração.

599 Esse é, aliás, o procedimento adotado na prática por muitas companhias para evitar os procedimentos custosos e demorados dos comitês independentes. Assim, várias operações entre partes relacionadas têm seguido o seguinte procedimento: o acionista controlador negocia as condições da operação de incorporação com os minoritários que possuem maior participação acionária e, depois, não vota na deliberação da assembleia geral (cf. N. EIZIRIK, A Lei das S/A comentada ... cit., p. 513).

600 Vide nesse sentido L. L. CANTIDIANO, Incorporação de sociedades e incorporação de ações... cit., p. 139 e 155; e L. L. CANTIDIANO, Análise crítica... cit., p. 146-147. O autor critica ainda a utilização de pareceres de orientação como instrumento para regulamentar matéria que não é de competência da CVM e para tratar genericamente de situações que deveriam ser analisadas caso a caso (idem, p. 153-154). No mesmo sentido, E. F. DE PONTES, Incorporação de ações no direito brasileiro... cit., p. 188-189. 
valor do patrimônio líquido a preços de mercado) e não cabe à doutrina ou à CVM criar um regime alternativo. ${ }^{601}$

Outra crítica refere-se aos comitês independentes sugeridos pelo PO CVM 35 no que diz respeito às funções assumidas por seus membros, como pseudoadministradores. Tais conselheiros se encarregam de negociar a relação de substituição das ações que é tarefa exclusiva e indelegável da diretoria conforme consta nos arts. 139 e 144, caput e parágrafo único, da Lei das S.A., não podendo ser atribuída aos membros do conselho de administração ou a órgãos estatutários criados na forma do art. 160 da Lei das S.A. Além disso, os comitês estariam também usurpando competências do Conselho de Administração, a quem cabe aprovar as condições finais da operação, especificamente o protocolo de incorporação. ${ }^{602}$ Nesse ponto, a CVM rebate dizendo que as companhias delegam poderes para terceiros a todo tempo, e, desde que a decisão final permaneça com o conselho de administração, não haveria problemas em tal delegação. ${ }^{603}$

Também é preciso se ponderar que existe toda uma gama de deveres fiduciários estipulados para os administradores na Lei das S.A. cuja aplicação para os membros do comitê independente não foi especificamente definida. Assim, permanecem abertas muitas questões, como a extensão de sua responsabilidade ao término do negócio, o modo de interpretar o dever de diligência ou dever de lealdade para membros nomeados para representar o interesse dos minoritários, extensão das regras de conflito de interesses para tais conselheiros, entre outros. ${ }^{604}$

No mérito, inúmeros são também os questionamentos feitos à efetividade dos comitês independentes e de seu papel como solucionador do conflito entre controladores e minoritários nas operações de incorporação diante das restrições de poderes a eles delegados e da incapacidade de tais comitês de efetivamente negociarem os termos da

601 Cf. PAS CVM n. 2007/3453, rel. Dir. Pedro Marcilio, j. 18.04.2007.

602 Cf. L. L. CANTIDIANO, Incorporação de sociedades e incorporação de ações... cit., p. 155.

603 Cf. voto do diretor Marcos Barbosa Pinto no Processo CVM n. RJ 2009/13179, rel. Dir. Alexsandro Broedel Lopes, j. 09.09.2010. Sobre a matéria, vide as ponderações de D. A. VIO, P. L. CASAGRANDE e R. P. FREOA no sentido de que as limitações dos poderes da administração são auto-impostas e a delegação de competências é muitas vezes admitida (Conflito de interesse... cit., p. 188).

604 Vide E. F. DE PONTES, Incorporação de ações no direito brasileiro... cit., p. 87-88. 
operação. ${ }^{605}$ Em sentido contrário, também existe a preocupação de que tais comitês se tornem independentes demais, impedindo operações que atenderiam aos interesses da companhia e dos minoritários. ${ }^{606}$

Embora inspirado no caso decidido em Delaware, o PO CVM 35 focou apenas na questão do fair dealing test abordado no caso estadunidense, ${ }^{607}$ editando um parecer de orientação que detalha os deveres fiduciários a serem seguidos com base nas propostas do direito americano de modo que crie um procedimento especial para as operações de incorporação de sociedades sob controle comum. ${ }^{608}$ Por essa razão, E. F. DE PONTES dispara uma segunda ordem de críticas ao PO CVM 35 afirmando que o processo montado com comitês independentes não atacou diretamente o principal foco dos litígios, que era obter uma relação de troca mais favorável aos minoritários por meio de uma avaliação independente. Em muitas operações, a intenção dos acionistas não é impedir propriamente a operação, mas garantir que a contraprestação ou o reembolso recebido pelos minoritários fosse adequado. Em outras palavras, em vez de propor negociações e decisões por comitês independentes em nomes dos acionistas ou ainda decisões em assembleia tomadas sem a presença do controlador, seria melhor que o sistema criado permitisse uma reavaliação independente dos termos da operação por meio de um mecanismo formal de revisão, semelhante ao que existe para a revisão do preço das ofertas públicas de aquisição para

605 Para que o mecanismo de comitês funcione de maneira adequada, é necessário que não assumam uma posição de meros avaliadores ou fantoches do controlador, devendo ter poderes para efetivamente negociar a operação (cf. voto de Marcos Barbosa Pinto no Processo CVM n. RJ 2009/13179, rel. Dir. Alexsandro Broedel Lopes, j. 09.09.2010). Nesse sentido, vide, por exemplo, as diversas críticas feitas ao comitê independente utilizado na incorporação da Aracruz pela VCP no que se refere à efetividade das negociações entre os membros do comitê e à carência de informação quanto ao parecer e aos trabalhos desse comitê especial (Preferencialistas felizes, Revista Capital Aberto, n. 73, p. 66, set. 2009; Será tudo encenação, Revista Capital Aberto, n. 71, p. 26, jul. 2009; e Independência dos Comitês de Incorporação está à prova, Revista Capital Aberto, n. 69, p. 8-9, maio 2009).

606 Vide G. SUBRAMANIAN, Fixing freezeouts cit., p. 12-13; e C. M. TOMAZELLA, Proteção de acionistas $e$ credores... cit., p. 104.

607 Por outro lado, no memorando que deu origem ao PO CVM 35, a CVM reconhece que não está em uma posição favorável para avaliar a equidade das relações de troca, o que seria apurado no contexto do fair price, mas está em posição privilegiada para avaliar os procedimentos que possam proporcionar uma negociação independente, no contexto do fair dealing.

Vide nesse sentido E. F. DE PONTES, Incorporação de ações no direito brasileiro... cit., p. 83. O autor critica também o fato de que as soluções do caso norte-americano foram criadas para proteger os acionistas do principal conflito de interesses existente naquele país, qual seja, aquele entre os acionistas e a administração da companhia, o que na casuística brasileira é ainda inexistente. Nos demais países (com exceção do Reino Unido), a existência de um controlador ou grupo de controle definido faz com que o principal conflito de agência verificado seja aquele entre controlador e minoritários, o que exigiria soluções específicas para essa situação, já que adotar as soluções americanas de governança corporativa pode se mostrar exagerado ou insuficiente para cada caso, impondo custos de ineficiência para a transação (vide K. HOEFSTETTER, One size does not fit all... cit., p. 4 e 19). 
cancelamento de registro como previsto no art. $4 .^{\circ}$-A e $\S \S$ da Lei das S.A. Dessa maneira, os processos de incorporação de sociedades sob controle comum deveriam optar por mecanismos de convalidação com base nos appraisal rights e nos testes de fair price iniciados nos caso Weinberger, em vez de interferir na estrutura do processo criando uma fase de negociação que não se encaixa de maneira técnica no nosso sistema. ${ }^{609}$ Nesse mesmo sentido, N. EIZIRIK sugeriu que

ao invés de "engessar" a atuação dos administradores, poderiam ser aceitos pela CVM outros procedimentos, como, por exemplo, permitir aos acionistas minoritários o requerimento de outro laudo de avaliação, alternativo àquele apresentado pelo controlador, de tal sorte que houvesse um novo escrutínio por parte de avaliador independente sobre a equidade das relações de troca. ${ }^{610}$

Por outro lado, ainda que concordemos com os benefícios das propostas acima, é necessário admitir que a CVM não poderia criar um sistema de convalidação como o acima proposto por conta da inexistência de disposição legal que garanta aos minoritários uma reavaliação formal e independente da operação e, dentro da limitação dos seus poderes, a CVM utilizou as vias que entendeu possíveis para elaborar o PO CVM 35, justificando-o como um detalhamento dos deveres fiduciários dos administradores já existentes em nossa Lei das S.A.

Por fim, o PO CVM 35 foi também censurado em vista de sua solução alternativa de submeter a aprovação da operação à maioria dos acionistas não-

609 Incorporação de ações no direito brasileiro... cit., p. 94-95. O autor aponta ainda outros problemas ligados à importação de soluções norte-americanas baseadas no fair dealing test. Para ele, um sistema de "negociações efetivas" em detrimento de um sistema que privilegie os appraisal rights pode ser altamente negativo mesmo para um judiciário célere e com excelência no assunto como o do Estado de Delaware. Ao adotarmos esses parâmetros, estaríamos também adotando esse tipo de problema, agravados ainda por um judiciário não tão eficiente como o norte-americano. Além disso, existe certa limitação em enrijecer a vertente do fair dealing, pois, ainda que qualquer acionista conteste a condução das negociações e tenha sucesso em seu pleito, o que tal acionista receberá é uma compensação monetária equivalente ao que teria na solução do appraisal, sendo que o fair dealing resultou, no sistema americano, apenas para que haja a inversão do ônus da prova. No mesmo sentido, a AMEC (Associação dos Investidores nos Mercado de Capitais) já se manifestou que umas das possíveis revisões do PO CVM 35 seja a possibilidade de o Conselho de Administração da companhia buscar um novo laudo de avaliação (Incorporações de controlada ainda são alvo de queixas de minoritários, Valor Econômico, 7.12.2011, disponível em <http:/www.valor.com.br/impresso/eu-investimentos/ incorporacoes-de-controlada-ainda-sao-alvo-de-queixas-de-minoritarios>, acesso em: 1 jan. 2014).

610 A Lei das S/A comentada... cit., p. 513-514. Em nota de rodapé a esse texto, o autor ainda acrescenta que é nesse sentido a regulamentação adotada na minuta do Código de Autorregulamentação do Comitê de Aquisições e Fusões. 
controladores, inclusive titulares de ações sem direito de voto. Sobre essa questão, remetemos aos nossos comentários feitos sobre o PO CVM 34 no item 3.4.3 abaixo onde esse problema é ainda mais evidente. Por ora, basta dizer que esse mecanismo cria impedimento de voto que não existe na lei e pode gerar situações igualmente arriscadas, em que caberia aos minoritários decidir o destino da companhia.

Com essas críticas em mente, E. F. DE PONTES lembra ainda outro sistema de convalidação que poderia ter sido utilizado para obtenção de uma relação de troca justa em operações entre sociedades sob controle comum: o mecanismo do peer review baseado no direito inglês. Nesse sistema, as operações de incorporação devem ser revistas sob as regras do City Code por meio de análise conduzida por pares do mercado que formam uma espécie de tribunal de integração da regulação e autorregulação que desempenha uma função híbrida entre o público e o privado, conhecido como Take Over Panel, ${ }^{611}$ cuja principal função é julgar a justiça e adequação dos processos de fusão e aquisição em vista das práticas de governança consubstanciadas no City Code. ${ }^{612}$ O City Code, por sua vez, é estruturado sobre uma gama de princípios, entre os quais destacamos a equidade de tratamento e a oportunidade para os acionistas.

Na esteira do que se vê no sistema inglês, a ideia de constituir um Take Over Panel no Brasil começou a tomar forma desde meados dos anos 2000 sob um projeto que desaguou na proposta em curso para a constituição do Comitê de Aquisições e Fusões (CAF) e o do Código de Autorregulação de Aquisições e Fusões. Assim como o Panel, o CAF também seria composto de representantes do mercado englobando companhias abertas, órgãos de classe como IBGC e Abrasca, autarquias como a CVM e entes de regulação como Anbima e a BM\&FBovespa. A proposta de criação do CAF tem o grande mérito de trazer para a realidade brasileira um sistema de autorregulação que lide com o

611 Nos dias de hoje, o Panel funciona por meio de um órgão colegiado cujo presidente é eleito por voto direto do Banco da Inglaterra, junto com outros dois membros. São eleitos também para compor o colegiado mais três membros indicados pela comunidade e por órgãos paritários de classe e de mercado. Membros adicionais são indicados por entidades do setor financeiro, perfazendo um total de 17 membros, incluindo os 6 membros do colegiado e membros dos subcomitês formados por assunto e especialidade.

612 As questões de valuation e appraisal rights não estariam, portanto, excluídas da apreciação do Judiciário (cf. E. F. DE PONTES, Incorporação de ações no direito brasileiro... cit., p. 98). 
mecanismo de convalidação das operações, o que ainda é bastante incipiente no país e pode se mostrar como instrumento eficiente para sua regulação. ${ }^{613}$

Atualmente, o sistema brasileiro ainda peca por ter deixado de lado tanto um mecanismo de revisão direta, semelhante ao que se encontraria nos appraisal rights, quanto de revisão por pares, que seriam fundamentais para validação das operações e solução de litígios. O fato é que a regulação existente não atacou de frente a questão dessas operações, qual seja, a contraprestação recebida pelos minoritários, seja pela relação de troca das ações ou via exercício do direito de recesso. Esse fato, somado a um processo exótico criado pelo PO CVM 35, tem sugerido uma oscilação entre o autoritarismo do controlador contrabalanceado pelo autoritarismo do minoritário. ${ }^{614}$

\subsection{Operações Envolvendo Relações de Substituição entre Ações de Espécies Diferentes}

\subsubsection{Modificação de Direitos dos Acionistas e Aprovação das Operações}

No direito comparado, operações de incorporação que acarretem alteração dos direitos dos acionistas titulares de categorias especiais de ações costumam exigir a aprovação de tais acionistas em votação em separado, ainda que eles não tenham direito a voto. Nesse sentido, a Diretiva 2011/35 da UE estabelece em seu art. 5. ${ }^{\circ}$, letra f, que o projeto de fusão elaborado pelos órgãos da administração deve estabelecer "os direitos assegurados pela sociedade incorporante aos acionistas que gozem de direitos especiais e aos portadores de títulos diferentes das ações, ou as medidas propostas relativamente a eles". ${ }^{615}$ Em seguida, seu art. 7., item 2, estabelece que "se existirem várias categorias de ações, a deliberação de fusão deve ficar subordinada a uma votação separada, a efetuar, pelo menos, por cada uma das categorias de acionistas cujos direitos sejam afetados pela operação".

613 Especula-se que na regulamentação a ser proposta pelo CAF, o controlador seja impedido de votar ou o minoritário possa requerer um novo laudo de avaliação. Além disso, é possível que o CAF venha até mesmo a substituir os comitês independentes citados no PO CVM 35 (Aquisições mediadas, Valor Econômico, 04.03.2011).

614 Cf. E. F. DE PONTES, Incorporação de ações no direito brasileiro... cit., p. 99-100.

615 No mesmo sentido, art. 98/1 “j” do Código das Sociedades Comerciais de Portugal e art. 2501-ter do Codice Civile italiano. 
Seguindo as recomendações da Diretiva 2011/35, algumas legislações exigem a aprovação dos acionistas titulares de direitos especiais em assembleia em separado, independentemente de ser ou não verificada alguma modificação nos direitos de tais acionistas. $^{616}$

Em outros casos, a aprovação por assembleia especial só é exigida quando as alterações decorrentes das operações de incorporação afetarem os direitos, as preferências e as vantagens das classes especiais de acionistas, como ocorre nas legislações da Itália e da Espanha. A definição do que sejam os acionistas afetados, no entanto, não é livre de controvérsias. Se, por um lado, a reestruturação econômica e social que decorre de uma operação de incorporação não se ajusta ao regime de manutenção dos direitos especiais conferidos aos acionistas, por outro, a manutenção formal de um direito dentro de um contexto absolutamente novo também pouco funciona como instrumento de proteção aos acionistas. É necessário, portanto, avaliar o que caracteriza afetar os direitos especiais de determinado acionista no âmbito de uma operação de incorporação.

Menor divergência na doutrina existe quando a alteração dos direitos é formal e direta, como, por exemplo, no caso de redução dos dividendos fixos, ou ainda quando a operação em questão causar um prejuízo indireto aos acionistas de determinada classe como, por exemplo, acarretar uma redução do capital social utilizado como base para cálculo de um dividendo fixo. ${ }^{617}$

No entanto, maiores dificuldades se apresentam nos casos de modificações que não são necessariamente formais, mas que afetam os direitos dos acionistas de maneira indireta. Exemplos de tais casos podem ocorrer quando houver atribuição de novos direitos a outros acionistas, criação de nova classe ou espécie de ações com direitos que prevalecem sobre os antigos acionistas ou no caso de alterações na proporção entre as

616 Vide, por exemplo, (i) art. 103-3 do Código das Sociedades Comerciais de Portugal; (ii) artigo L236-9 do Code de Commerce da França; e (iii) § 907 do Companies Act do Reino Unido.

617 Cf. C. M. TOMAZella, Proteção de acionistas e credores... cit., p. 61. Vide também A. VICARI, Gli Azionisti... cit., p. 186 e 202. 
diferentes espécies de ações decorrente da compenetração dos acionistas em uma única sociedade. $^{618}$

Nesse ponto, são em geral considerados direitos afetados aqueles que não correspondem a direitos equivalentes medidos de acordo com um critério de equivalência material. Esse critério, a ser apurado pela administração das companhias, pressupõe a manutenção do mesmo interesse do sócio que era previamente visado, só que agora dentro de uma nova estrutura social. ${ }^{619}$ Assim, para dispensar as assembleias especiais, os administradores deveriam fazer com que os acionistas titulares de ações com direitos especiais não sofram um prejuízo ao "direito especial" que possuem representado, por um lado, pela atribuição de um direito não idêntico (lesão direta) ou pela criação de novas categorias com direitos prevalecentes sobre as ações que antes detinham direitos especiais ou pela alteração na proporção entre as diversas categorias, ainda que permaneçam os privilégios originais de tais acionistas (lesão indireta). ${ }^{620}$ Quanto a esse último ponto, em que se discute a necessidade de aprovação em assembleia especial por conta de alterações nas proporções entre as diferentes espécies de ações decorrentes da própria compenetração dos sócios, há bastante divergência na doutrina. Alguns autores entendem que as alterações decorrentes da compenetração dos acionistas são inevitáveis e, portanto, não requerem que sejam previamente aprovadas por assembleias especiais, enquanto outros defendem que modificações nas posições relativas dos sócios afetariam seus direitos e poderiam ocasionar prejuízos e, portanto, deveriam estar sujeitas a prévia aprovação. ${ }^{621}$

A Lei das S.A., por sua vez, silenciou sobre a necessidade de aprovação dos preferencialistas em assembleia especial nos casos de substituição de ações preferenciais por outras espécies de ações ou por ações com direitos diferentes dos originalmente

618 Cf. A. VICARI, Gli Azionisti... cit., p. 210.

619 Cf. D. C. GONÇALVES, Fusão, cisão e transformação... cit., p. 205-208.

620 Cf. A. VICARI, Gli Azionisti... cit., p. 189.

${ }^{621}$ No sentido de que as alterações na proporção das ações devem ser aprovadas pelas assembleias especiais, vide C. SANTAGATA, La Fusione Tra Società... cit., p. 269. Para o autor, adotada essa posição, só seriam dispensadas as assembleias especiais nos casos de incorporação entre companhia controladora e subsidiária, de modo que não seriam alteradas as proporções anteriormente existentes. Vide também A. VICARI, Gli Azionisti... cit., p. 212-213. Em sentido contrário, advogando que as alterações nas proporções são meras decorrências das operações, vide L. J. CORTÉS DOMINGUES; A. PÉREZ TROYA apud C. M. TOMAZELLA, Proteção de acionistas e credores... cit., p. 61. 
detidos. $^{622}$ A possibilidade de modificação dos direitos conferidos vem, inclusive, expressamente definida no inciso II do art. 225 da Lei das S.A. ao requerer que a justificação exponha "as ações que os acionistas preferenciais receberão e as razões para a modificação dos seus direitos, se prevista".

Questiona-se, então, se, diante da omissão da Lei das S.A. no que diz respeito às operações de incorporação, haveria necessidade de titulares de ações preferenciais que tenham seus direitos modificados aprovarem a operação em assembleia especial nos termos do $\S 1 .^{\circ}$ do art. 136 da Lei das S.A. ${ }^{623}$

Sobre esse ponto, alguns autores entendem que deveria ser conferido o direito de aprovação em votação em separado para os acionistas que tivessem seus direitos e privilégios alterados em virtude de modificações que não fossem decorrentes diretamente da necessidade de unificação dos quadros de acionistas em uma única sociedade em virtude da incorporação. ${ }^{624}$ Nessa linha, a atribuição de ações ordinárias em virtude da incorporação para acionistas preferencialistas deveria ser previamente aprovada em assembleia especial, salvo se houvesse prévia previsão estatutária para tal conversão. ${ }^{625}$

Em sentido contrário, outra corrente entende que a Lei das S.A. não determina que sejam emitidas, em substituição às ações que desaparecem ou são incorporadas, ações idênticas àquelas detidas anteriormente pelos acionistas, e que, portanto, fica a critério da administração das sociedades envolvidas estabelecer o número, a espécie e a classe de

622 Essa omissão, inclusive, recebeu críticas de W. BULGARELLI, Fusões, incorporações... cit., p. 224. Em sentido contrário, vide as críticas feitas às assembleias especiais como mecanismo efetivo de proteção aos minoritários dada a fragilidade dos acionistas preferencialistas em resistirem às propostas dos acionistas titulares de ações ordinárias (cf. V. BRUDNEY, Standards of Fairness and the Limits of Preferred Stock Modifications, 26 Rutgers L. Rev. 445, 1972-1973, p. 448).

623 Lei das S.A.: “Art. 136. É necessária a aprovação de acionistas que representem metade, no mínimo, das ações com direito a voto, se maior quorum não for exigido pelo estatuto da companhia cujas ações não estejam admitidas à negociação em bolsa ou no mercado de balcão, para deliberação sobre: [...]

II - alteração nas preferências, vantagens e condições de resgate ou amortização de uma ou mais classes de ações preferenciais, ou criação de nova classe mais favorecida; [...]

$\S$ 1. ${ }^{\circ}$ Nos casos dos incisos I e II, a eficácia da deliberação depende de prévia aprovação ou da ratificação, em prazo improrrogável de um ano, por titulares de mais da metade de cada classe de ações preferenciais prejudicadas, reunidos em assembleia especial convocada pelos administradores e instalada com as formalidades desta Lei".

624 Nesse sentido, vide T. DE MIRANDA VALVERDE, Sociedade por ações..., v. III, cit. p. 82; C. F. DA Cunha PEIXOTO, Sociedade por ações, v. 5, São Paulo: Saraiva, 1972-73, p. 21; e C. M. TOMAZELLA, Proteção de acionistas e credores... cit., p. 62.

625 C. M. TOMAZELlA, Proteção de acionistas e credores... cit., p. 63. 
ações que serão atribuídas aos acionistas da sociedade incorporada. Em consonância com o princípio majoritário, a maioria acionária teria competência para decidir sobre o número, a espécie e a classe de ações que serão atribuídas aos novos acionistas ${ }^{626}$ e os administradores teriam a discricionariedade para fixação da espécie e classe de ações que serão atribuídas independentemente também de alterações nas proporções entre ordinárias e preferenciais. ${ }^{627}$ Portanto, a alteração nos direitos dos preferencialistas por decisão majoritária independeria de prévia aprovação pelos acionistas afetados, já que o art. 136 da Lei das S.A. não menciona expressamente as operações de incorporação quando trata das alterações que afetam as ações preferenciais e, ao mesmo tempo, tal modificação está expressamente prevista na lei como consequência da própria operação aprovada. ${ }^{628}$

Segundo essa corrente, a Lei das S.A., quando entendeu ser o caso, estabeleceu expressamente a necessidade de prévia aprovação, como o fez para os debenturistas afetados. No entanto, teria propositalmente silenciado sobre a necessidade de aprovação dos preferencialistas em assembleia especial nos casos de substituição de ações preferenciais por outras espécies de ações. Entende-se, assim, que a alteração nos direitos dos preferencialistas, ainda que para pior, constitui consequência da operação, muitas vezes inevitável, e que, aos olhos do legislador, o direito de recesso em função da própria operação de incorporação constitui instrumento de defesa suficiente dos minoritários descontentes com a operação. ${ }^{629}$

Também nesse sentido, a CVM já decidiu no Processo CVM n. RJ 2004/2274, rel. SEP, j. 20.04.2004, que a incorporação de ações com atribuição de ações ordinárias a preferencialistas não exigia prévia aprovação em assembleia especial porque, na verdade, não há criação de ações preferenciais ou modificação de direitos de ações preferenciais

626 Cf. M. CARvalhosa; N. EIZIRIK, A nova Lei das S/A... cit., p. 375.

627 M. CARVAlHOSA; N. EIZIRIK, Estudos de direito empresarial... cit., p. 189 e 211.

628 Vide nesse sentido D. KALANSKY, Incorporação de ações... cit., p. 265.

629 Cf. N. EIZIRIK, A Lei das S/A comentada... cit., p. 236. Vide também M. CARVALHOSA ao dizer que "a não-manutenção dos direitos conferidos às ações preferenciais da sociedade fusionada é uma consequência legítima da operação de fusão, visto que a lei societária não exige que esses acionistas da sociedade fusionada recebam da companhia ações idênticas às que possuíam anteriormente. [...] Não cabe, assim, falar em recesso na fusão, com base no art. 137, I, combiando com o art. 136, II, da Lei n. 6.404/76 [...] em decorrência de alteração das vantagens conferidas às ações preferenciais." (Comentários à Lei de Sociedades Anônimas, v. 1, cit., p. 182). 
como previsto pelo art. 136 da Lei das S.A., e sim atribuição de novas ações em lugar daquelas detidas anteriormente. ${ }^{630}$

Assim, embora seja defensável que a legislação deveria ter previsto assembleia especial para alteração das preferências e vantagens das ações nos moldes do que existe hoje em solo europeu, entendemos que não foi essa a regulação prevista na Lei das S.A. A impossibilidade de os acionistas da incorporada ou daqueles que têm suas ações incorporadas reivindicarem direitos estatutários ou contratuais decorrentes de suas antigas ações ou quotas decorre, aliás, do próprio desaparecimento de tais ações como consequência das incorporações e da extinção da companhia envolvida no caso das incorporações de sociedades, além do fato de que os novos direitos são conferidos exclusivamente de acordo com o estatuto da sociedade incorporadora nos termos negociados no negócio de incorporação aprovado. ${ }^{631}$

Não obstante, existem limites ao poder da maioria para que se possa promover a alteração das espécies e das classes de ações. O próprio inciso II do art. 225 da Lei das S.A. determina que sejam explicitadas na justificação "as ações que os acionistas preferenciais receberão e as razões para a modificação dos seus direitos". Esse artigo teria, portanto, uma dupla função: a primeira é informar amplamente os preferencialistas sobre o quadro acionário em que estarão inseridos a partir da conclusão da operação, bem como as cláusulas estatutárias que governarão seus direitos políticos e patrimoniais; a segunda função é informar as razões que justificam as modificações aos preferencialistas afetados.

Assim, alterações nas espécies e classes de ações poderão ser feitas apenas quando houver razões para fazê-lo em função da conveniência do negócio e em estrito cumprimento do interesse social das companhias em efetivá-lo. ${ }^{632}$ Nesse sentido, M. CARVALHOSA entende que o legislador, quando fala em razões, não utilizou linguagem jurídica, devendo ser entendido como causa, ou seja, como o fim econômico da

630 Em sentido contrário, na operação de incorporação de ações de emissão da Aracruz pela VCP, a Superintendência de Relações com Empresas recomendou que fosse seguido o art. 136, $\S 1 .^{\circ}$, da Lei das S.A.

631 Vide A. LAMY Filho; J. L. Bulhões Pedreira (Coord.), Direito das companhias, v. 2, cit., p. 1765.

632 Nesse sentido, vide A. LAMY FILHO; J. L. BUlHÕES PEDREIRA (Coord.), Direito das companhias, v. 2 , cit., p. 1765 e N. EIZIRIK, A Lei das S/A comentada... cit., p. 235. 
modificação proposta. ${ }^{633}$ De posse dessa informação, o acionista preferencial poderá analisar sua situação e decidir se exercerá ou não seu direito de recesso. Por exemplo, uma das razões clássicas que justificam as modificações nos direitos das ações preferenciais é o interesse da companhia aberta incorporadora de ter apenas uma classe de ação preferencial, o que obviamente proporciona maior liquidez a tais ações. ${ }^{634}$ Pode ser conveniente também que a companhia aberta resultante da incorporação tenha somente ações ordinárias com vistas a listá-las no Novo Mercado, em que somente podem ser negociadas ações com direitos plenos de voto. ${ }^{635}$

\subsubsection{Relações de Substituição Diferenciadas entre Ações de Espécies Diferentes}

Discutimos anteriormente a possibilidade de modificação dos direitos dos acionistas em relação àqueles que originalmente possuíam no âmbito de uma operação de incorporação, bem como a necessidade de realização de assembleia especial de acionistas para convalidar tais alterações. No entanto, conforme ensina V. BRUDNEY, na verdade, os maiores problemas não dizem respeito à questão dos poderes dos acionistas titulares de ações ordinárias para alterar os direitos dos acionistas preferencialistas, e sim à justiça dessas alterações, dada, inclusive, a considerável dificuldade em identificar e medir os direitos que estão sendo extintos em comparação com aquilo que está sendo atribuído aos acionistas. ${ }^{636}$ Assim, ainda que as alterações nos direitos especiais dos acionistas sejam possíveis, o poder da maioria em alterar as participações dos preferencialistas não significa que tais acionistas deram ampla liberdade aos acionistas com direito de voto para alterar a divisão das participações no capital da companhia como bem entendam. É necessário,

633 M. Carvalhosa, Comentários à Lei de Sociedades Anônimas, v. 4, t. I cit., p. 257.

634 A experiência do mercado demonstra que a existência de mais de uma classe de ações preferenciais em negociação nas bolsas de valores não é conveniente para a companhia ou para os acionistas do ponto de vista da liquidez, pois uma maior quantidade de ações negociada de cada espécie ou classe de ações afeta negativamente a liquidez das negociações (cf. A. LAMY FILHO; J. L. BULHÕES PEDREIRA (Coord.), Direito das companhias, v. 2, cit., p. 1766). Nesse mesmo sentido, N. EIZIRIK, A Lei das S/A comentada... cit., p. 235-236.

635 Em sentido oposto, parece ser contestável a prática realizada em algumas companhias de atribuir ações preferenciais resgatáveis aos acionistas em função da relação de troca estabelecida, as quais são imediatamente resgatadas e convertidas em dinheiro com pagamento aos acionistas, fazendo com que, na prática, a contraprestação seja em dinheiro e não em ações. Vide, por exemplo, Instrumento de Justificação e Protocolo de Incorporação de Ações da Company S.A. pela Brascan SPE SP-3 S.A., de 10 de setembro de 2008; e Protocolo e Justificação de Incorporação de Ações de emissão da Bovespa Holding S.A. pela Nova Bolsa S.A., de 17 de abril de 2008.

636 Standards of Fairness... cit., p. 446. 
portanto, avaliar a forma de determinação da relação de troca de ações nas operações de incorporação e a possibilidade e/ou necessidade de haver relações de substituição distintas para ações de espécies diferentes.

Essa discussão já foi debatida no Brasil e no exterior havendo opiniões em diferentes sentidos. Uma primeira corrente entende que a relação de troca deve ser a mesma para todos os acionistas, independentemente dos direitos conferidos pelas diversas espécies de ações, pois tais direitos não seriam relevantes na determinação da relação de troca entre as sociedades que se fundem ou se incorporam, pois, se pudessem ser capitalizados, alguns sócios passariam a ter porcentagens de capital na sociedade resultante que não guardariam equivalência com a porcentagem de capital possuída anteriormente pelos mesmos acionistas. ${ }^{637}$

Parecem se filiar a essa corrente opiniões manifestadas por certos autores, por exemplo, no contexto das chamadas two step acquisitions estudadas também no direito norte-americano, que são operações em que determinada pessoa adquire o controle de uma companhia para, em seguida, realizar a incorporação da mesma companhia. ${ }^{638}$ Nesse tipo de operação, entende-se que o que ocorre é uma cessão de empresa e tudo se passa como se a sociedade incorporadora tivesse adquirido a totalidade do acervo empresarial da incorporada, pagando a esta o preço de aquisição, e não apenas uma aquisição do poder de controle. $^{639}$

Defende-se, assim, uma regra de tratamento igualitário entre todos os acionistas na operação, de modo que o controlador não receba sozinho o valor de todo o acervo empresarial porque a operação pretendida, na verdade, aproxima-se do que ocorreria se o adquirente tivesse pagado o preço para comprar todos os ativos da

637 Vide OleO apud A. PÉREZ TROYA, La determinación del tipo de canje... cit., p. 73.

638 Vide V. BRUDNEY; M. A. CHIRELSTEIN, Fair Shares... cit., p. 330. No Brasil, adotou-se uma maneira que é também chamada de three step acquisition, que se constitui na (i) aquisição do controle; (ii) tag along aos minoritários ordinaristas pelo valor de $80 \%$ do preço de aquisição do pago ao cedente do controle; e (iii) deliberação sobre incorporação ou incorporação de ações após a aquisição do controle (cf. D. KALANSKY, Incorporação de ações... cit., p. 97).

639 Vide CALIXTO SAlOMÃo FILHO, O novo direito societário cit., p. 154. 
companhia adquirida e essa quantia fosse depois distribuída entre os acionistas de acordo com um processo de liquidação. ${ }^{640}$

Nessa linha, F. K. COMPARATO, citado no voto de Luiz Leonardo Cantidiano no âmbito do Processo CVM n. RJ 2003/12770, rel. SEP, j. 26.12.2003, entende que

é antijurídico que esse preço total de aquisição da empresa (e não o preço de aquisição do controle simplesmente) seja distribuído aos acionistas da incorporada, desproporcionalmente à sua participação no acervo empresarial. Nem estão as partes no negócio de cessão de controle (primeira etapa do conjunto de operações), isto é, o antigo e o novo controlador, legitimados a determinar, como quiserem, a maneira de distribuição aos acionistas não controladores, desse valor da empresa cedida; ou, o que é pior, autorizados a privar tais acionistas de qualquer participação nesse valor. Seria isso defraudar os não controladores do direito fundamental à manutenção de seu status socii.

No mesmo processo, o diretor Luiz Leonardo Cantidiano defende o tratamento equitativo entre todos os acionistas da sociedade independentemente da espécie de ações que possuírem, sustentando ser inadmissível "justificar a disparidade de valor entre o preço arbitrado, no negócio de transferência da empresa, entre as ações ordinárias e preferenciais de emissão da sociedade que vinha explorando a empresa que é objeto de cessão". ${ }^{641} \mathrm{E}$ continua ao dizer que

o acionista minoritário, seja ele titular de ação preferencial ou ordinária, deve sempre e em qualquer situação receber o valor da empresa nas operações de incorporação, sendo irrelevante que a incorporação ocorra seguidamente à aquisição do controle ou muito após. A ação deve ser sempre avaliada, nestas hipóteses, como uma fração, uma parte-alíquota, do valor do negócio, como um todo, de sorte que isoladamente não deveria haver diferença entre o valor de cada ação. ${ }^{642}$

Como se percebe, a corrente que defende o tratamento igualitário entre todos os acionistas, independentemente da espécie de ações, geralmente baseia seus argumentos

640 Cf. V. BRUdney; M. A. CHIRELSTEIn, Fair Shares... cit., p. 334-335.

641 Voto de Luiz Leonardo Cantidiano no âmbito do Processo CVM n. RJ 2003/12770, rel. SEP, j. 26.12.2003

642 Voto de Luiz Leonardo Cantidiano no âmbito do Processo CVM n. RJ 2003/12770, rel. SEP, j. 26.12.2003. 
nas regras de participação dos acionistas no acervo social. Essa interpretação decorre do fato de se encarar as operações de incorporação de sociedades como um procedimento simplificado de dissolução sem liquidação da companhia, levando por fim à extinção da sociedade. ${ }^{643}$ A esse respeito, F. K. COMPARATO, tratando sobre o procedimento das operações de incorporação, diz expressamente que "[e]sse procedimento abreviado, de dissolução sem liquidação, somente se aplica quando se respeita, integralmente, o status patrimonial dos sócios da incorporada". ${ }^{644}$ No mesmo sentido, N. J. PARENTE entende que, em que pese a lei admitir a liberdade de escolha dos critérios para o cálculo do fator da relação de substituição proposto, o livre-arbítrio não é absoluto, pois esbarra na obrigação de controladores e de administradores agirem com lealdade com o acionista minoritário e no direito de os acionistas participarem do acervo da companhia, em caso de liquidação, proporcionalmente à participação no capital social. ${ }^{645}$

Se as operações de incorporação, de fato, tiverem que seguir as regras da distribuição do patrimônio social aplicáveis à liquidação, parece-nos impossível defender que se possam atribuir relações de troca diferenciadas entre acionistas preferenciais e ordinaristas de acordo com os direitos de tais ações, pois isso poderia implicar alteração na participação no capital social detida por cada acionista. Na verdade, respeitadas as regras de liquidação, mais do que pregar o tratamento equitativo entre todos os acionistas, seria até mesmo possível admitir que as ações preferenciais pudessem ter relação de troca mais favorável do que as ordinárias caso a elas fossem conferidas vantagens como prioridade no reembolso do capital, ainda mais se houver prêmio nesse reembolso, ou dividendos cumulativos ainda não pagos pela companhia.

Nesse sentido, V. BRUDNEY propõe que sejam utilizados como parâmetro de justiça das modificações nas operações de incorporação os direitos que os acionistas especiais teriam em caso de liquidação das ações uma vez que, em termos econômicos, as contraprestações recebidas em operação de incorporação se assemelhariam à redistribuição

643 Cf. A. de A. GonçAlves Neto, A fusão, a incorporação e a cisão... cit., p. 76; M. CARVALHOSA; N. EIZIRIK, Estudos de direito empresarial... cit., p. 90.

644 Parecer citado na manifestação de voto do diretor Luiz Leonardo Cantidiano no Processo CVM n. RJ 2003/12770, rel. SEP, j. 26.12.2003.

645 N. J. PARENTE, Maioria não basta, Revista Capital Aberto... cit., p. 52. No mesmo sentido, W. BULGARELLI defende que a operação de incorporação deveria ser equiparada à liquidação da sociedade (Fusões, incorporações... cit., p. 224). 
de ativos que também ocorre entre acionistas preferenciais e ordinários e para a qual foram criadas as regras de liquidação. Dessa maneira, seria possível evitar que os preferencialistas perdessem mais do que ganhariam com a conclusão da operação. ${ }^{646}$

Como se vê, embora a ideia de que as operações de incorporação devam seguir as regras de participação no acervo social seja, geralmente, utilizada para defender um tratamento equitativo entre todos os acionistas, a mesma noção poderia ser utilizada para defender uma relação de troca diferenciada e mais benéfica aos preferencialistas com base nas vantagens que tais acionistas teriam na eventual liquidação da companhia. Por essa razão, não nos parece coerente defender o tratamento igualitário entre todos os acionistas ordinaristas e preferencialistas para a determinação da relação de substituição de ações com base em tais regras.

A nosso entender, o que é necessário assegurar é que os acionistas titulares de ações preferenciais ou ordinárias não sejam privados de seu direito fundamental (nos termos do art. 109 da Lei das S.A.) de participar no acervo da companhia quando este estiver sendo alienado a terceiros, pois esse valor pertence a todos os acionistas e não apenas ao controlador. ${ }^{647}$ Esse era, na verdade, o intuito por trás da edição do antigo art. 255 da Lei das S.A. ${ }^{648}$ que pregava o tratamento equitativo entre todos os acionistas nas hipóteses de alienação do controle de companhias sujeitas à autorização, criado como resposta às incorporações de instituições financeiras comuns a partir da década de 1950 em que o valor dos intangíveis dessas companhias (cartas-patentes para funcionamento) eram atribuídos apenas ao controlador, ${ }^{649}$ bem como a razão da famosa decisão proferida pelo

646 Standards of Fairness... cit., p. 484.

647 Vide A. LAMY FILHO; J. L. BUlhões PedreIRA, A Lei das S.A. - Parte III - Pareceres... cit., p. 645 e 673.

648 Lei das S.A. (revogado pela Lei n. 9.457, de 1997): “Art. 255. A alienação do controle de companhia aberta que dependa de autorização do governo para funcionar e cujas ações ordinárias sejam por força de lei, nominativas ou endossáveis, está sujeita à prévia autorização do órgão competente para aprovar a alteração do seu estatuto.

§ 1. ${ }^{\circ}$ A autoridade competente para autorizar a alienação deve zelar para que seja assegurado tratamento equiitativo aos acionistas minoritários, mediante simultânea oferta pública para a aquisição das suas ações, ou o rateio, por todos os acionistas, dos intangíveis da companhia, inclusive autorização para funcionar.

$\S 2 .^{\circ}$ Se a compradora pretender incorporar a companhia, ou com ela se fundir, o tratamento eqüitativo referido no $\S 1 .^{\circ}$ será apreciado no conjunto das operações."

649 Para um histórico dessas operações e da edição do artigo de lei em questão, vide A. LAMY FILHO; J. L. BUlHÕes PEDREIRA, A Lei das S.A. - Parte III - Pareceres... cit., p. 653-666. Vide também F. K. COMPARATO; CAliXto SAlOMÃo FILHO, O Poder de Controle... cit., p. 269-275; A. WALD, 
STJ no mesmo sentido obrigando o rateio dos intangíveis para todos os acionistas e que é muitas vezes mencionada quando se discute a distinção entre a mera alienação do controle acionário e a cessão de toda a organização empresarial. ${ }^{650}$ A nosso ver, no entanto, garantir a participação de todos os acionistas no acervo empresarial a que têm direito nos casos de cessão da empresa não significa a obrigatoriedade de que a relação de troca de ações preferenciais tenha que ser, em qualquer caso, a mesma que aquela estabelecida para os acionistas ordinaristas. Tanto é assim que a oferta pública exigida nos termos do antigo art. 255 da Lei das S.A. que visava justamente a assegurar a participação dos acionistas no acervo empresarial podia prever preços distintos para ações de espécies diferentes, ${ }^{651}$ bem como o tratamento equitativo aos acionistas poderia ser avaliado no momento da incorporação após a compra do controle, conforme previsto no antigo $\S 2 .^{\circ}$ do art. 255 , desde que ficasse demonstrado que a relação de troca das ações considerou não apenas o valor do patrimônio líquido contábil das sociedades, mas também o valor dos intangíveis da companhia. ${ }^{652}$ Isto é, se a relação de troca das ações fosse baseada em uma avaliação correta do patrimônio das companhias, que já considerasse os intangíveis de uma e de outra sociedades, assegurado estaria o tratamento equitativo aos acionistas e a sua participação em todo o acervo da companhia, ainda que as relações de troca fossem diferenciadas entre ordinaristas e preferencialistas.

Além disso, a aproximação entre a figura da incorporação e das regras de rateio de patrimônio social em caso de liquidação para determinação da relação de troca de ações

Considerações sobre a aquisição e alienação de controle societário: o estudo da jurisprudência, Revista dos Tribunais, v. 691, maio 1993, p. 21; L. L. CANTIDIANO, Alienação e aquisição de controle, Revista de Direito Bancário e do Mercado de Capitais, n. 34, São Paulo: RT, 2006, p. 333 e 336; e A. WALD, A proteção dos acionistas minoritários na alienação do controle de companhias abertas, Revista de Direito Bancário e do Mercado de Capitais, n. 34, São Paulo: RT, 2006, p. 354.

650 STJ, Resp. n. 34.834-5-PR, rel. Ministro Waldemar Zveiter, j. 14.09.1993. A decisão em questão determinou a extensão aos minoritários preferencialistas do valor pago na oferta pública de aquisição de controle obrigando o rateio entre todos os acionistas do valor dos intangíveis da companhia. Vide sobre o tema CALIXTO SALOMÃo FILHO, O novo direito societário cit., p. 153.

651 A. LAMY Filho; J. L. BUlhões PEdReIRA, A Lei das S.A. - Parte III - Pareceres... cit., p. 677. Vide também, A. WALD, afirmando que o preço oferecido nos termos do antigo art. 255 podia ser diferente entre as ações de espécies diferentes e, inclusive, diferente do preço oferecido ao acionista controlador (A proteção dos acionistas minoritários... cit., p. 356-357).

652 A. LAmY Filho; J. L. Bulhões PedreIRA, A Lei das S.A. - Parte III - Pareceres... cit., p. 673 ; e A. WALD, A proteção dos acionistas minoritários... cit., p. 357. Em sentido semelhante, M. CARVALHOSA entende que a aquisição de controle seguida de incorporação não deve garantir nenhum preço ou relação de troca aos acionistas a serem incorporados que tenha como base a operação de aquisição anterior, dado que se trata de negócios independentes regulados por normas específicas, válidos na medida em que cada um respeitar sua própria regulação (M. CARVALHOSA; N. EIZIRIK, Estudos de direito empresarial... cit., p. 121). 
não é livre de contestação. Como se sabe, a incorporação de sociedade acarreta a extinção da sociedade, sem que sobre ela se apliquem os institutos da dissolução e da liquidação, pois a operação é causa direta de extinção da sociedade por força do art. 209, II, da Lei das S.A. Assim, não se confunde com a liquidação porque não há partilha de seu ativo entre os sócios e não há liquidação de débitos e obrigações prévios à extinção, sendo que os sócios não recebem nenhuma parcela do patrimônio líquido, que é transferido diretamente para a incorporadora. ${ }^{653}$ A avaliação das ações ou do patrimônio das sociedades no contexto de uma operação de incorporação também se contrapõe radicalmente à avaliação no contexto de uma liquidação, pois as operações de incorporação pressupõem a continuidade da empresa e a criação de uma nova sociedade cujo valor seja superior ao valor das sociedades individuais, diferente do encerramento de uma companhia no contexto da liquidação. ${ }^{654}$

Aliás, como vimos neste trabalho, o que as sociedades e os sócios buscam com uma operação de incorporação passa longe da extinção da companhia, sendo muito mais um ato positivo das companhias de agregação de seus negócios do que um ato que se aproxime da liquidação da companhia. Para as operações de incorporação de ações, o paralelo com a figura da dissolução e liquidação fica ainda mais distante, já que a sociedade cujas ações são incorporadas sobrevive e continua a ter personalidade jurídica após a concretização da operação e, não obstante, para fins de determinação da relação de substituição de ações, as diferenças entre as operações são quase inexistentes.

Passemos então a analisar o posicionamento contrário àqueles que defendem o tratamento equitativo entre todos os acionistas. Essa segunda corrente, em sentido radicalmente oposto, entende que a existência de diferentes espécies de ações obviamente deverá ser considerada no momento da fixação da relação de troca de modo que, além de uma paridade relativa entre as ações ordinárias, deverá ser estabelecida também uma paridade especial em relação às ações preferenciais. ${ }^{655}$

653 Cf. M. Carvalhosa, Comentários à Lei de Sociedades Anônimas, v. 4, t. I cit., p. 270 e E. L. TeIXeIRA; J. A. TAVARes GUerReIRo, Das Sociedades Anônimas... cit., p. 666.

654 Cf. L. A. BIANCHI, Il Giudizio di “Congruità ”... cit., p. 175.

655 Vide J. SANCHEZ OLIVÁN, La fusión de sociedades... cit., p. 30-32; e R. LARGO GIL apud A. PÉREZ TROYA, La determinación del tipo de canje... cit., p. 73. Vide também voto do Diretor Otavio Yazbek no caso Duratex/Satipel ao dizer que a proporcionalidade na distribuição do patrimônio não vigora 
Nesses casos, portanto, o princípio da paridade de tratamento entre os sócios não se aplicaria, ou melhor, aplicar-se-ia de maneira distinta quando se tratar de ações de espécies diferentes, pois seria indiscutível a possibilidade de tratamento diferenciado dos acionistas de espécies diferentes de ações na relação de troca. ${ }^{656}$ Entre ações ordinárias e preferenciais não haveria, portanto, obrigatoriedade de se observar o tratamento igualitário entre os acionistas no contexto das operações de incorporação, como também já se reconheceu a admissibilidade de tratamento diferenciado entre acionistas titulares de ações de espécies diferentes em outras oportunidades. Exemplificativamente, comentando a discriminação entre acionistas preferencias e ordinários na oferta pública por conta de alienação de controle, M. CARVALHOSA defende que o princípio do tratamento igualitário dos acionistas depende da igualdade dos títulos por eles possuídos. ${ }^{657}$ No mesmo sentido, A. WALD entende que a igualdade só pode ser garantida a acionistas que tenham títulos idênticos, fungíveis uns em relação aos outros, justificando que não pode haver discriminação entre ações iguais pelo fato de pertencerem umas ao controlador e outras aos minoritários, mas jamais esse tratamento igualitário poderia servir de base para uma equiparação entre ações distintas, com direitos diferentes. ${ }^{658}$

Até mesmo o CAF, que se baseia no princípio da igualdade de tratamento entre todos os acionistas, admitiu na minuta de regulação sugerida a diferenciação entre preferencialistas e ordinaristas para operações de incorporação e para determinação dos

quando há diferentes espécies de ações, não havendo como adotar uma mesma racionalidade para a definição das relações de troca de ações ordinárias e ações preferenciais.

Cf. L. A. BIANCHI, Il Giudizio di “Congruità”... cit., p. 196.
Cf. M. CARvalhosa; N. EIZIRIK, Estudos de direito empresarial... cit., p. 120.
Cf. A oferta pública, igualdade dos acionistas e o direito comparado, Revista de Direito Mercantil Industrial, Econômico e Financeiro, n. 43, São Paulo: RT, 1981, p. 18. O mesmo princípio foi aceito pelas legislações europeias, que admitem a distinção entre as espécies de ações na regulamentação da alienação de ações do controlador (idem, p. 17). No direito norte-americano, W. D. ANDREWS reconhece que a igualdade dos acionistas não pode ser admitida para acionistas de categorias diferentes de ações, sendo descabido igualar acionistas votantes e não votantes dada a natureza distinta de tais ações (The Stockholders' Right to Equal Opportunity in the Sale of Shares, 78 Harv. L. Rev., 1964-1965, p. 558). Também já foi permitido o tratamento diferenciado entre acionistas preferenciais e ordinários quando a CVM admitiu a possibilidade de haver preços distintos para ações preferenciais e ordinárias no que se refere ao pagamento do preço justo citado no art. $4 .^{\circ}, \S 4 .^{\circ}$, da Lei das S.A. (cf. Processo CVM n. RJ 2005/3917, rel. SER, j. 31.01.2006). No exterior, a Segunda Diretiva 77/91/CEE do Conselho, de 13 de dezembro de 1976, referente às garantias exigidas das sociedades para constituição da sociedade anônima, bem como à conservação e às modificações do seu capital social, a qual justamente sugeriu a inserção nas legislações do princípio do tratamento equitativo, referia-se, nesse caso, apenas aos acionistas que estivessem em condições idênticas. Vide art. 42 da diretiva em questão e também F. D’ALESSANDRO, La Seconda Diretiva... cit., 1987, I, p. 1. 
preços de ofertas públicas por alienação de controle, em que os ordinaristas receberiam $100 \%$ do preço pago ao controlador e os preferencialistas apenas $80 \%{ }^{659}$

Concordamos com essa posição, pois entendemos que as diferenças na relação de troca envolvendo ações de espécie diferentes se dão como exigência natural de refletir os diversos direitos incorporados às ações e que têm por escopo reconstruir, na sociedade que recebe os acionistas, o equilíbrio que existia entre os sócios antes da realização da operação. ${ }^{660}$ Se as relações de troca devem procurar manter a posição jurídica dos sócios e reconstruir na sociedade incorporadora o mesmo status socii que havia antes da incorporação, é natural que se admitam diferenças na relação de troca entre ações ordinárias e preferenciais com base nas distinções que já existiam entre tais acionistas antes da incorporação, dada a dependência existente entre as antigas e as novas participações recebidas pelos sócios e o caráter de continuidade da posição jurídica dos acionistas característico das operações de incorporação.

Admitida a diferenciação na relação de troca entre ações preferenciais e ordinárias, resta saber então quais os critérios que nortearão essa diferenciação e o modo de determinação de uma "dupla" relação de troca a depender da espécie e classe de ação sendo entregue pela sociedade incorporada ou cujas ações serão incorporadas.

Como vimos acima, alguns autores defendem que sirvam como parâmetro de justiça os direitos que os acionistas preferenciais teriam em caso de liquidação da companhia, o que entendemos não ser o melhor parâmetro de comparação dada a dificuldade em promover uma exata aproximação entre as figuras da liquidação e da incorporação.

Para A. VICARI, a existência de mais de uma categoria de ações requer que seja estabelecida uma "dupla" relação de troca (ou mais do que apenas dupla, se houver mais de uma espécie ou classe de ação com diferentes direitos) para que tais relações de troca possam ser consideradas justas e, ao mesmo tempo, respeitosas dos direitos dos acionistas

659 Vide Selo da paz?, Revista Capital Aberto, n. 108, ago. 2012; e Selo de qualidade, Revista Capital Aberto, n. 96, ago. 2011.

660 Nesse mesmo sentido, vide L. A. BIANCHI, Il Giudizio di "Congruità"... cit., p. 101. 
titulares de direitos especiais. ${ }^{661}$ Assim, uma vez que seja avaliado o patrimônio das sociedades envolvidas, deve-se, primeiro, estabelecer a paridade interna da relação de troca, isto é, a relação de troca entre as ações pertencentes a categorias diversas e as ações ordinárias para cada uma das sociedades envolvidas na operação a fim de determinar qual a quota do patrimônio atribuível, respectivamente, às ações preferenciais e às ações ordinárias. Posteriormente, deve-se então estabelecer a paridade externa, ou seja, a relação de troca entre as ações de cada espécie e as ações da sociedade que emitirá as ações a serem recebidas pelos acionistas, sem abrir mão, é claro, dos critérios de maximização da rentabilidade dos acionistas que já estudamos neste trabalho.

Para respeitar a paridade "interna" e promover a diferenciação entre as ações de diferentes espécies, os administradores deveriam estimar, de modo analítico, o conteúdo dos direitos patrimoniais atribuíveis às diversas categorias de ações (ordinárias, de um lado, e preferenciais, de outro). ${ }^{662}$ No entanto, como tais procedimentos são dificilmente factíveis já que comportam escolhas subjetivas e chegam a um resultado final dificilmente comprovável, a solução privilegiada na prática e proposta pelo autor consiste em determinar os valores das diversas espécies de ações em proporção aos respectivos preços de bolsa, medidos oportunamente sobre uma base temporal que seja capaz de dar resultados consistentes. ${ }^{663}$ Se as ações em questão não forem cotadas em bolsa, propõe o autor que as características dos privilégios políticos e patrimoniais deveriam ser avaliados com base em ações de outra sociedade similar que seja cotada em bolsa. ${ }^{664}$

No Brasil, é bastante comum vermos operações de incorporação propondo relações de troca diferenciadas para ações de espécies diferentes de acordo com as quais as

661 Gli Azionisti... cit., p. 187. No mesmo sentido, vide L. A. BIANCHI segundo quem, "per quanto la prassi dimonstri uma netta predilezione per um unico rapporto di cambio, l'eventualità della determinazione di un concambio differenziato in presenza di categorie di azioni trova fondamento, sul piano giuridico, nel tenore dell'art. 2501-bis [ora ter], $1^{\circ}$ c, n. 7, c.c., laddove eso impone di indicare, all'interno del progetto di fusione, 'il trattamento riservato a particolari categorie di azioni'" (apud A. VICARI, Gli Azionisti... cit., p. 187).

662 Idem, ibidem, p. 188.

663 Essa diversidade de cotações costuma decorrer basicamente das características específicas a cada tipo de ação, quer de caráter eminentemente econômico, como, por exemplo, a rentabilidade atribuída à ação, quer de indiscutível repercussão econômica, como o respectivo índice de negociabilidade. De fato, as características específicas a cada tipo de ação, embora não tenham repercussão sobre seu valor patrimonial, inegavelmente influenciam suas cotações no mercado em virtude de seus intrínsecos componentes financeiros e econômicos (Parecer de Orientação CVM n. 5, de 3 de dezembro de 1979).

A. VICARI, Gli Azionisti... cit., p. 189. 
ações preferenciais recebem relação de troca inferior às ações ordinárias com base, justamente, nas cotações de tais ações em bolsa. ${ }^{665}$ No entanto, a premissa de que as ações ordinárias de uma companhia deveriam valer mais do que as preferenciais por conta do direito de voto e do direito de tag along nem sempre é verdadeira. A análise econômica do valor de negociação das ações em bolsa demonstra que o valor de uma ação ordinária ou preferencial depende de uma série de outros fatores que fazem com que, nem sempre, as ações ordinárias sejam negociadas por preço superior. ${ }^{666}$ Entre tais fatores, citamos diferenças de liquidez ou na geração de fluxo de caixa entre ordinárias e preferenciais, questões ligadas à conjuntura e momento histórico em que tais ações estão sendo negociadas, ${ }^{667}$ percepção do mercado a respeito da possibilidade de haver ou não alienação de controle em futuro próximo, ${ }^{668}$ pressões de preço vindas do exterior, entre outros. ${ }^{669}$ Assim, essas variações nos preços das ações deveriam ser também tomadas em conta na determinação da relação de troca caso venham a afetar o preço das ações.

$\mathrm{Na}$ linha do que viemos defendendo acima, atualmente, a regulação sugerida pela CVM no PO CVM 34/2006 expressamente aceita a diferenciação de relações de troca em função das espécies de cada ação e propõe que tais diferenças sejam determinadas de acordo com laudos que considerem os diferentes valores econômicos de cada uma das ações com base em critérios objetivamente verificáveis, como o fluxo futuro de caixa descontado ou as diversas cotações em mercados organizados. ${ }^{670}$ Também já foram admitidos como critérios objetivamente verificáveis para justificar a diferença entre

665 De acordo com A. DI MICELI, o correto seria que tanto preferenciais como ordinárias tivessem o mesmo preço, uma vez que ambas, em princípio, conferem ao detentor o fluxo de caixa correspondente ao capital investido. No entanto, isso não acontece porque quem possui ações ordinárias pode fazer prevalecer seus interesses e isso é valorizado pelo mercado (vide Uma questão de valores, Revista Capital Aberto, n. 74, p. 26, out. 2009).

Vide Uma questão de valores, Revista Capital Aberto... cit., p. 22-26, out. 2009.

667 Por exemplo, o preço das ações ordinárias caiu muito quando o governo revogou, por meio da Lei n. 9.457, de maio de 1997, o art. 254 da Lei das S.A. que garantia o tag along aos acionistas minoritários.

668 Nesse ponto, a profusão das operações de incorporação pode até mesmo fazer com que o preço das ações ordinárias se aproxime das ações preferencias, vez que nessas operações não há tag along para os minoritários.

669 Sobre motivos para as possíveis diferenças nos preços das ações ordinárias e preferenciais, vide Uma questão de valores, Revista Capital Aberto... cit., p. 22-26, out. 2009.

670 A utilização de critérios objetivos também já foi utilizada pela autarquia para admitir a distinção de preço entre ações preferenciais e ordinárias nos processos de aquisição de ações citado no art. $4 .^{\circ}, \S 4 .^{\circ}$, da Lei das S.A. No Processo CVM n. RJ 2005/3917, rel. SER, j. 31.01.2006, a CVM decidiu que o preço admitiria valores diferentes para cada espécie de ação desde que fossem considerados elementos objetivos no laudo de avaliação (quando se tratar de avaliação por valor econômico), como, por exemplo, diferentes direitos patrimoniais atribuídos às classes de ações preferenciais, ou da utilização do valor de mercado das ações que tenham diferentes valores de cotações. 
ordinárias e preferenciais a negociação entre partes independentes que determinou o sobrevalor das ações com direito a voto na linha do que vem sendo adotado pela autarquia em suas decisões, enquanto as ações preferenciais tiveram sua relação de troca determinada pela cotação em bolsa. ${ }^{671}$ Caso sejam utilizados outros critérios não objetivos, entende a autarquia que os acionistas titulares de ações com voto estarão impedidos de votar por ficar configurado benefício particular nos termos do art. $115, \S 1 .^{\circ}$, da Lei das S.A. ${ }^{672-673}$ A nosso entender, mais do que impedimento de voto, a diferenciação entre as ações que não esteja baseada em critérios objetivos que possam ser determinados pela administração configuraria ilegalidade.

Outras manifestações da CVM em relação à diferenciação de preços entre ações ordinárias e preferenciais também podem ser aproveitadas para o contexto das operações de incorporação. Nesse sentido, analisando a possível distinção de preços justos entre ações ordinárias e preferenciais no contexto de ofertas para cancelamento de registro, a autarquia informou que as hipóteses de favorecimento de uma espécie ou classe de ações em detrimento de outras só podem ser verificadas no caso concreto, ${ }^{674}$ o que, a nosso ver, é

671 Vide Processo CVM n. RJ 2008/10.832, rel. Dir. Otavio Yazbek, j. 10.07 .2012 a respeito da incorporação de ações do Unibanco Holdings S.A. e do Unibanco pelo Itaú Unibanco Holding S.A. Não obstante, o argumento de que houve negociação entre partes independentes não foi suficiente para afastar o entendimento de que havia benefício particular quando as relações de troca fossem diferentes para ações da mesma espécie, conforme veremos no item 3.4.3 abaixo.

672 Críticas ao conceito de benefício particular utilizado pelo PO CVM 34 serão feitas de maneira mais detalhada no item 3.4.3 abaixo.

673 Na incorporação da Aracruz pela VCP, o comitê independente da Aracruz realizou análise complementar sobre a relação de valor de mercado entre ações ordinárias e preferenciais de companhias listadas e apurou que, na média, as ações preferencias são negociadas a 0,9 do valor das ordinárias, pretendendo usar esse fator de desconto como critério objetivo na determinação da relação de troca. A decisão da autarquia negou essa possibilidade, no entanto, entendendo que os dados apresentados não constituíam critérios objetivos. Contrariamente à posição da autarquia, L. L. CANTIDIANO se posicionou dizendo que a relação de troca foi estabelecida sobre critério objetivo que equivale ao desconto usualmente praticado pelo mercado ao negociar ações ordinárias e preferenciais com alta liquidez (vide Preferencialistas felizes... cit., p. 67). A nosso entender, a questão aqui não se trata necessariamente de tal critério ser ou não objetivo, mas muito mais por utilizar uma média de mercado que pode não ser aplicável às companhias envolvidas. A falta de critérios objetivos também levou a questionamentos sobre a existência de impedimento de voto quando foi anunciada a possível operação de incorporação de ações entre Pão de Açúcar e Carrefour (vide O Estado de S. Paulo, 30.06.2011, Economia, p. B15). Nos termos da proposta da operação, as ações preferenciais da Companhia Brasileira de Distribuição, pertencente ao Grupo Pão de Açúcar, seriam convertidas em ordinárias à razão de 1 ação preferencial para 0,95 ações ordinárias e, em seguida, seriam incorporadas pela empresa que formaria, no futuro, a holding do novo Grupo Pão de Açúcar (vide fato relevante emitido pela Companhia Brasileira de Distribuição em 28 de junho de 2011). A falta de justificativa para que as ações preferenciais fossem convertidas com certo desconto imediatamente antes da incorporação levantou suspeitas de que os acionistas controladores estariam impedidos de votar na operação nos termos do PO CVM 34. 
compatível com a exigência de que os critérios utilizados sejam objetivos como requerido para os casos das incorporações. Ainda, a CVM também já se pronunciou no sentido de ser necessário considerar, em tese, o Parecer de Orientação CVM n. 5, de 3 de dezembro de 1979, que condiciona a utilização do critério de cotação de mercado para a fixação do preço de emissão em aumentos de capital à existência de liquidez de tais ações como requisito para justificar a diferenciação de preços que utilizam a cotação em bolsa como parâmetro. ${ }^{675}$ Da mesma forma, a ICVM 319 veda a utilização do critério de cotação em bolsa se as ações em questão não integrarem índices de liquidez. Assim, entendemos que a diferenciação de preços entre ordinárias e preferenciais com base em cotação em bolsa somente será válida se as diversas espécies de ações apresentarem cotações no mercado significativamente díspares e tiverem expressivos índices de negociabilidade. Relativamente à primeira condição, é necessário ainda esclarecer que a diferença de cotações deve ter como causa as características intrínsecas e de caráter exclusivamente econômico das ações, e não se originar de intenções ou comportamentos específicos de seus titulares. ${ }^{676}$

Por essa razão, não seriam admissíveis diferenças na relação de troca das ações que decorram de práticas abusivas do próprio controlador decorrentes, por exemplo, do anúncio da operação. É possível, por exemplo, que o controlador detentor de ações ordinárias anuncie ao mercado uma operação que é prejudicial para os acionistas preferenciais e, por conta dessas informações, o mercado imediatamente reduza o valor das ações preferenciais aumentando o spread entre as ações ordinárias e preferenciais. Essa situação pode durar algum tempo, abrindo flanco para que um valor distorcido de tais ações seja considerado, por exemplo, para determinar uma relação de troca que se baseasse na cotação das ações no mercado. Essa prática naturalmente configuraria abuso de poder de controle ou até mesmo prática não equitativa conforme definição da Instrução CVM n. 8 , de 8 de outubro de $1979 .{ }^{677}$

Por fim, pelo outro lado da moeda, questão curiosa também se coloca quando uma parte das ações a serem entregues são ordinárias e outra parte preferenciais, enquanto todas as ações incorporadas ou da sociedade incorporada eram ordinárias. Nesse caso, o

\footnotetext{
675 Cf. Processo CVM n. RJ 2005/3917, rel. SER, j. 31.01.2006.

676 Cf. Parecer de Orientação CVM n. 5, de 3 de dezembro de 1979.

677 Vide L. SILVA, $O$ valor justo... cit., p. 71.
} 
atendimento ao princípio paritário exige que a distribuição das ações ordinárias e preferenciais seja feita na proporção das ações ordinárias entregues de modo que não haja discriminação entre os sócios. ${ }^{678}$

\subsection{Operações Envolvendo Relações de Substituição Diferentes para Ações de Mesma Espécie}

O mercado brasileiro tem assistido nos últimos tempos operações de incorporação em que se propõem relações de substituição de ações diferentes para ações da mesma espécie e classe ${ }^{679} \mathrm{Em}$ tais operações, cuja legalidade é amplamente debatida, ${ }^{680} \mathrm{o}$ que se observa é uma relação de troca mais benéfica para o acionista controlador em função do sobrepreço (prêmio) que geralmente se atribui às ações pertencentes ao bloco de controle. Essa problemática, aliás, só existe por conta da ampla liberdade que a nossa Lei das S.A. permite para a determinação da relação de troca também pela ausência de previsões expressas de que a substituição de ações tenha que ser feita na proporção das antigas participações como existe, por exemplo, na legislação espanhola ou portuguesa. ${ }^{681}$

Este item, portanto, pretende confrontar a posição daqueles que entendem ser possível a atribuição de um sobrepreço às ações do controlador e aqueles que defendem que tal sobrepreço seria injustificável no contexto de operações de incorporação. Essa análise é, inclusive, de extrema relevância porque, na medida em que se admite a realização de operações com relação de troca diferenciada para ações da mesma espécie, teríamos uma nova hipótese de extração de benefícios particulares pelo controlador e de apropriação de prêmio de controle sem qualquer previsão legal para sua limitação ou seu rateio com os minoritários. ${ }^{682}$ Isso porque, até hoje, o parâmetro de que as ações dos minoritários valem $80 \%$, no mínimo, das ações do controlador tem sido respeitado mesmo

678 Vide A. PÉREZ TROYA, La determinación del tipo de canje... cit., p. 111.

679 Exemplos dessas operações são a incorporação da Duratex S.A. pela Satipel Indutrial S.A. aprovada em 31.08.2009 e a incorporação de ações da Sadia S.A. pela BRF Brasil Foods S.A. aprovada em 18.08.2009, às quais já nos referimos neste estudo.

680 Vide, por exemplo, M. G. PEDRETTI, Prática difundida. Revista Capital Aberto, n. 74, out. 2009, p. 46 e C. A. JunQueira De SIQUeIRA, Ato de liberalidade. Revista Capital Aberto, n. 74, out. 2009, p. 47, respectivamente a favor e contra a admissibilidade de tais operações. Vide também Incorporações continuam a premiar bloco de controle, Revista Capital Aberto, n. 71, julho 2009.

681 Cf. também C. M. TOMAZELla, Proteção de acionistas e credores... cit., p. 124.

682 Cf. E. S. MunHOZ, Desafios do direito societário na companhia aberta... cit., p. 147. 
nos casos das operações de incorporação. No entanto, os argumentos de que as relações de troca são livremente negociadas e de que não há vedação à atribuição de prêmio de controle em operações de incorporação, geralmente utilizados por aqueles que defendem operações nesses termos, poderiam justificar prêmios de controle muito superiores às proporções que vêm sendo hoje praticadas. ${ }^{683}$

\subsubsection{Prêmio de Controle em Operações de Incorporação}

Diferentemente do que ocorre nas hipóteses de alienação do poder de controle reguladas pelo art. 254-A da Lei das S.A., a atribuição de um prêmio às ações do controlador no contexto das operações de incorporação não é expressamente reconhecida nem vedada pela Lei das S.A. e, por isso, essa possibilidade é bastante controversa. ${ }^{684}$

Por um lado, há aqueles como W. J. WARDE JR. e D. KALANSKY que defendem a possibilidade de haver prêmio de controle em operações de incorporação porque a relação de substituição não se basearia apenas em contraprestações patrimoniais, mas seria também fundada em vantagens atribuídas aos controladores. ${ }^{685}$ Além disso, não haveria qualquer vedação expressa na Lei das S.A. que impedisse a atribuição de uma relação de troca de ações diferenciada entre acionistas da mesma espécie. ${ }^{686}$ Também no direito estrangeiro há aqueles que defendem a atribuição de um prêmio ao acionista controlador como forma de proceder a uma correta avaliação do valor intrínseco da participação de tal

683 Vide nesse sentido, Fim do privilégio, Revista Capital Aberto, n. 72, ago. 2009.

684 Convém relembrar que até mesmo para as hipóteses de alienação do poder de controle muito já se debateu sobre a titularidade do sobrevalor das ações do bloco de controle e sobre a consequente admissibilidade de atribuição do prêmio exclusivamente para o controlador ou, ao contrário, a necessidade de rateio de tal prêmio com os demais acionistas da companhia, havendo inúmeros trabalhos a respeito das vantagens e desvantagens de uma ou outra posição. Nesse sentido, a teoria dividi-se entre aqueles que pregam a absoluta liberdade do controlador para vender suas ações e receber o prêmio de controle e aqueles que defendem uma regra de tratamento igualitário entre todos os acionistas na ocasião da venda de controle, obrigando o adquirente a fazer uma oferta pública para aquisição das ações dos demais acionistas. Para uma análise das diferentes posições e suas vantagens e desvantagens, vide E. S. MUNHOZ, Aquisição de controle acionário: alienação e tomada, tese para obtenção do título de livre-docente em Direito Comercial pela Faculdade de Direito da Universidade de São Paulo, 2011, p. 162-172. Vide também A. C. BARBUiO; A. C. C. ZORICIC; R. F. V. AlCADE, Incorporação de sociedade e incorporação de ações. Incidência do art. 254-A da Lei das Sociedades Anônimas, in: E. S. MUNhoz, M. R. PENTEAdo (Coord.), Mercado de Capitais brasileiro - Doutrina, cases \& material, São Paulo: Quartier Latin, 2012, p. 252. Vide W. J. WARDE JR., Os poderes manifestos... cit., p. 62 e D. KALANSKY, Incorporação de ações... cit., p. 111-113.

686 Cf. M. G. PEDRETTI, Prática difundida. Revista Capital Aberto, n. 74, out. 2009, p. 46. 
acionista no contexto das operações de incorporação. Segundo essa corrente, desconsiderado esse sobrevalor, haveria um enriquecimento injusto do acionista minoritário e um consequente dano ao acionista controlador em ter suas ações subavaliadas. Seria necessário, portanto, estabelecer uma dupla relação de troca, considerando-se primeiro a paridade "interna" entre as ações da mesma sociedade, momento em que seria reconhecido o prêmio na avaliação das ações do acionista controlador e, em seguida, a paridade "externa" entre as ações das sociedades envolvidas na operação. ${ }^{687}$

Como se vê, tais argumentos se baseiam no reconhecimento do sobrevalor atribuído às ações que asseguram o controle da companhia com base na lógica existente para os processos de alienação de ações em que se admite tal prêmio, conforme, inclusive, consta do art. 254-A da Lei das S.A.

Em sentido oposto, certos autores, cuja posição nos parece mais coerente, refutam essa aproximação, pois entendem que as operações de incorporação e de alienação de controle não se confundem em absoluto já que ambas as operações são regidas por princípios absolutamente diversos.

No primeiro caso, uma pessoa natural ou jurídica utiliza seus próprios recursos para adquirir ações de uma companhia que lhe garantam o controle. O acionista dessa companhia, por sua vez, efetivamente aliena o controle e deixa o quadro de sócios da companhia, recebendo dinheiro ou equivalente como contraprestação de suas ações, de forma que se verifica sempre o caráter oneroso da operação. ${ }^{688} \mathrm{Em}$ operações de incorporação, por sua vez, sabemos que o processo não é esse. No caso, os administradores responsáveis pela elaboração do protocolo negociam a transferência de toda a base acionária da companhia incoporada ou que terá suas ações incorporadas para a companhia incorporadora e não há desembolso de recursos ou venda e compra de ações (mas sim substituição de ações). Nesse caso, o acionista controlador da sociedade incorporada

\footnotetext{
687 Vide P. RIVA apud A. VICARI, Gli Azionisti... cit., p. 137-138.

688 Cf. D. KALANSKY, o direito de tag along somente se justifica como forma de estender aos minoritários parte do prêmio de controle recebido pelo controlador, por isso a onerosidade da transferência é elemento essencial à obrigatoriedade de realização de OPA por alienação de controle (Incorporação de ações... cit., p. 140).
} 
também permanece no negócio dentro da sociedade incorporadora, diferentemente do que ocorre no processo de alienação do poder de controle. ${ }^{689}$

Além disso, o processo decisório de uma operação de incorporação é absolutamente distinto de uma alienação de controle. Em operações de incorporação todos têm a chance de participar da operação, debater, votar e, eventualmente, exercer o direito de recesso. Ao contrário, em uma alienação de ações do acionista controlador não há qualquer decisão em assembleia e o instituto do tag along previsto no art. 254-A da Lei das S.A. serve, justamente, para integrar, a posteriori, os minoritários que não participaram do processo decisório e não puderam se beneficiar desse acontecimento. ${ }^{690}$

Outra distinção entre os dois processos também se dá porque o art. 254-A não estabelece um preço máximo ao destinatário da oferta, mas sim um valor mínimo que o minoritário pode ou não vir a aceitar. Esse é, aliás, ponto crucial na diferença entre as duas operações, pois enquanto a alienação de ações na oferta é uma faculdade do minoritário, nos processos de incorporação sabemos que a perda da sua participação na sociedade original é inevitável. ${ }^{691}$ A própria lógica do art. 254-A foi construída para lidar com uma consequência da alienação do poder de controle (a qual pode ser realizada pelo controlador a qualquer preço e a qualquer momento), dando ao minoritário que não deseje permanecer na sociedade sob a tutela do novo controlador o direito de sair da companhia, uma vez que a operação por si mesma não gera direito de recesso. Essa consequência da alienação de controle que é a oferta pública obrigatória, não pode, jamais, ser transformada em premissa para estabelecimento de uma relação de troca diferenciada para ações da mesma classe sem que isso gere uma ilegalidade, pois o art. 254-A não é uma autorização para avaliação distinta do bloco de controle e não seria legítimo tornar uma faculdade do minoritário em uma imposição a seu prejuízo. ${ }^{692}$

\footnotetext{
689 Vide E. F. DE PONTES, Incorporação de ações no direito brasileiro... cit., p. 135-136.

690 Idem, ibidem, p. 167.

691 Cf. também D. A. VIO; P. L. CASAGRAnde; R. P. FREOA, Conflito de interesse... cit., p. 174.

692 Cf. votos dos Diretores Marcos Barbosa Pinto, Eli Loria e Otavio Yazbek no caso Duratex/Satipel. Vide também E. F. DE PONTES, Incorporação de ações no direito brasileiro... cit., p. 213-214. O autor relembra ainda muito bem que o poder de controle é um poder de fato e não um poder de direito de forma que esse poder de fato não poderia receber avaliação especial no contexto da avaliação das ações ou do patrimônio das sociedades, pois não está embutido no complexo de direitos conferidos pelas ações em si e nem é um ativo reconhecido na companhia. Não é, portanto, um bem do patrimônio no sentido
} 
A distinção clara entre os dois processos também já foi aceita pela CVM quando ela teve a oportunidade de analisar a necessidade de aplicação do art. 254-A da Lei das S.A. para operações de incorporação em que houvesse troca de controle. Segundo a autarquia, não há alienação, cessão ou transferência de ações ou títulos que resultem na transferência do controle, conforme $\S 1 .^{\circ}$ do art. 254-A, porque a incorporação e a alienação de controle têm naturezas distinas e, além disso, a Lei das S.A. afasta qualquer dúvida a esse respeito ao tratar ambas as figuras de forma separada. ${ }^{693}$ A princípio, portanto, uma operação de incorporação, com ou sem prêmio de controle, não estaria coberta pelo art. 254-A da Lei das S.A. em virtude de sua própria natureza mesmo que acarrete a troca de controle da companhia, pois não há alienação, cessão ou transferência de ações ou títulos que resultem na transferência do controle e, portanto, não seria obrigatória a formulação de uma oferta pública de aquisição. ${ }^{694-695}$ De forma resumida, o

de direito subjetivo apreciável economicamente que possa ter um valor de avaliação com critérios determinados pela lei de forma distinta das ações que compõem o bloco de controle (Idem, p. 218). Sobre a lógica do tratamento igualitário em incorporações diferentemente do que ocorre na alienação de controle, vide A. WALD, Considerações sobre a aquisição... cit., p. 21.

693 Nesse sentido, vide voto do diretor Marcos Barbosa Pinto no Processo CVM n. RJ 2008/4156, rel. Dir. Sergio Weguelin, j. 17.06.2008. Vide também Memo SRE/N. 214/2008 divulgado pela CVM em 06.10.2008 a respeito das operações Datasul/Totus, Tenda/Gafisa e Company/Brascan. A. C. BARBUIO, A. C. C. ZORICIC e R. F. V. ALCADE também defendem a não aplicabilidade do artigo em questão em vista da distinção das naturezas jurídicas das operações e porque a Lei das S.A. já trouxe mecanismos próprios de proteção para cada uma das operações (Incorporação de sociedade e incorporação de ações... cit., p. 252).

694 Vide M. R. PENTEADO que, ao tratar da incorporação de ações, ensina que "a incorporação de ações para a constituição de subsidiária integral - operação societária típica, repita-se - além de não configurar 'alienação de ações', não importa, também, em 'alienação de controle"” (Reorganização operacional e societária. Ação declaratória de nulidade de deliberações de conselho de administração de S.A. Suposto conflito de interesses, Revista de Direito Mercantil Industrial, Econômico e Financeiro, n. 146, São Paulo: Malheiros, 2007, p. 260). Contra os argumentos jurídicos que tentaram classificar as operações de incorporação em que há troca de controle como sendo "abuso de direito", "simulação", "negócio indireto", "fraude à lei", vide D. KALANSKY, Incorporação de ações... cit., p. 141-146; e E. F. DE PONTES, Incorporação de ações no direito brasileiro... cit., p. 167. Convém notar, por outro lado, a preocupação manifestada por certos autores diante da legislação atual. E. F. DE PONTES, por exemplo, entende que a regulação existente para as consolidações de controle (operação definida pelo autor como incorporações de ações entre duas empresas independentes com controladores definidos em que um deles deixará de ser controlador) encontra-se em um limbo dantesco, pois não tem a proteção do PO CVM 34, nem do PO CVM 35, nem a alternativa do recesso de acordo com as regras do art. 264 da Lei das S.A. Em sentido semelhante, vide também W. J. WARDE JR., Os poderes manifestos no âmbito da empresa... cit., p. 78-80.

695 Caso se admitisse a aplicabilidade do art. 254-A da Lei das S.A., outro ponto controverso a ser resolvido diria respeito à uma questão operacional que não foi (e nem poderia ter sido dada a diferença de propósito) expressamente esclarecida pela Lei das S.A. Como o suposto pagamento ao antigo controlador não é feito em dinheiro ou bens, mas sim em ações recebidas em uma sociedade ou, até mesmo, mediante diluição na sociedade incorporadora em que já era controlador, o cálculo e a forma de compensação devida aos minoritários é bem menos clara. Esse fato gerou, inclusive, dissidência entre os entendimentos da SER e do Diretor Sérgio Weguelin no Processo CVM n. RJ 2008/4156, rel. Dir. Sergio Weguelin, j. 17.06.2008 sobre a contraprestação devida aos minoritários nas hipóteses de alteração de controle acionário por meio de uma operação de incorporação. 
entendimento acima leva em conta que, para se caracterizar uma alienação do controle acionário, para os efeitos da Lei das S.A., exige-se a presença cumulativa dos seguintes elementos: (i) aparecimento de um novo acionista controlador com a conclusão da operação; (ii) caráter oneroso da transferência; e (iii) transferência da totalidade ou parte das ações do antigo controlador. ${ }^{696}$ Nas operações de incorporação, não se observa efetivamente uma transferência ou alienação de ações do antigo para o novo controlador porque as novas ações são recebidas como consequência legal da operação conforme expusemos neste trabalho e tampouco existe um caráter propriamente oneroso da operação porque o antigo controlador não recebe uma contraprestação específica por suas ações. ${ }^{697}$

O art. 254-A da Lei das S.A. é um mecanismo típico de venda e compra de controle societário, mas a troca de controle por meio de uma operação de incorporação não é uma venda e não existe um preço pago pelas ações como viemos defendendo ao longo deste trabalho. Ainda que exista a negociação da relação de troca das ações entre as sociedades, isso não equivale a um desembolso de um acionista controlador para outro de forma a configurar uma compra e venda. São recursos da própria incorporadora que são criados a partir da captura do patrimônio da sociedade incorporada ou das ações a serem incorporadas, havendo em ambas as sociedades uma diluição justificada de suas posições, mas não propriamente uma alienação. O controlador da incorporadora não realiza nenhum desembolso, não paga ou entrega bens para adquirir o controle da sociedade incorporada ou cujas ações são incorporadas nem tampouco utiliza recursos da companhia incorporadora para adquirir o controle da incorporada. ${ }^{698}$

Além disso, a avaliação realizada para a determinação da relação de troca em nada equivale à formação do preço de uma alienação de ações. Referida avaliação deve observar a reconstrução do patrimônio da sociedade como um todo dentro do contexto de negociação da operação de incorporação, o que é bastante diferente de restringir essa avaliação às ações deste ou daquele acionista considerados de forma isolada. Até porque,

696 Cf. N. EIZIRIK, A Lei das S/A comentada... cit., p. 404; e D. KALANSKY, Incorporação de ações... cit., p. 140. Sobre a necessidade de que haja efetivamente uma transferência por parte do antigo controlador, vide também G. D. C. PEREIRA, Alienação do poder de controle ... cit., p. 293; e A. C. BARBUIO; A. C. C. ZORICIC; R. F. V. ALCADE, Incorporação de sociedade e incorporação de ações... cit., p. 253.

697 Nesse mesmo sentido, vide também A. VICARI ao dizer que "la fusione comporta tecnicamente um “cambio'di azioni e non una 'cessione' delle stesse, per cui ogni ragionamento in termini di premio como 'prezzo' di alcune delle stesse non appare approppriato" (Gli Azionisti... cit., p. 139). 
nas incorporações de sociedades, não se avaliam as ações, mas sim o patrimônio das sociedades envolvidas na operação e nas incorporações de ações, embora sejam as ações que devem ser avaliadas, essa avaliação está diretamente ligada ao patrimônio da sociedade e não às ações de determinado acionista (tanto é que a Lei das S.A. não estabelece critérios especiais de avaliação das ações para as incorporações de ações, utilizando as regras existentes para incorporação de sociedades). Esse fato, aliás, está intimamente ligado com o que já discutimos sobre a natureza jurídica das incorporações e da relação de troca como negócio entre sociedades e não entre acionistas, bem como sobre a necessidade de assegurar um tratamento equitativo sob a óptica "externa" da relação de troca, o que impediria que houvesse discriminação entre este ou aquele acionista como se cada um deles negociasse individualmente a troca de sua participação. Não se justifica, portanto, o argumento de que as ações do controlador deveriam ser avaliadas de forma mais benéfica em função do reconhecimento do prêmio de controle associado a tais ações, sendo, portanto, ilegítimo diferenciar entre as ações da mesma espécie e classe na determinação da relação de troca. ${ }^{699}$ Nessa mesma linha, D. A. VIO, P. L. CASAGRANDE e R. P. FREOA afirmaram que

a avaliação de participação societária para o cálculo de relação de troca em incorporação não guarda qualquer semelhança com a formação de preço em oferta pública por aquisição de controle. Tanto o exercício de controle $-\mathrm{e}$, portanto, o respectivo prêmio - quantos outros direitos, como a possibilidade de convocar assembleias ou de eleger representantes para o Conselho de Administraçao, são a consequência final de um determinado quadro acionário e não uma caracterísitica intrínseca das ações que formam tal cenário, quando individualmente consideradas. Uma ação integrante do bloco de controle, por si só, é apenas mais uma ação e, para o que releva em termos de avaliação relativa à incorporação, deve ser tratada como tal, ou seja, como mera fração representativa do valor da companhia. ${ }^{700}$

699 Cf. A. VICARI, ao dizer que "la valutazione del concambio [...] dovrebbe riguardari la ricostruzione del capitale economico della società (as a whole) e non anche del valore delle singole azioni calcolate isolatamente (valued alone)" (Gli Azionisti... cit., p. 139).

700 Conflito de interesse... cit., p. 175. Na mesma linha, E. VALlADÃo A. E N. FrAnÇA expõe que "o que ocorre é que, sendo a incorporação uma operação em que ocorre transferência de patrimônio, soa estranho que, na mesma operação, seja atribuído valor diverso às ações, como anotado no voto do ilustre Diretor Otavio Yazbek" (Ainda o conceito de benefício particular: anotações ao julgamento do processo CVM RJ-2009/5.811, Revista de Direito Mercantil Industrial, Econômico e Financeiro, n. 149/150, São Paulo: Malheiros, 2008, p. 322). 
Assim, parece-nos falacioso o argumento daqueles que defendem a possibilidade de atribuição de um prêmio de controle em operações de incorporação aproximando essa figura às alienações das ações que se regem pelo art. 254-A da Lei das S.A. em relação às quais tal prêmio é possível. Nesse sentido, corroboramos a opinião de E. F. DE PONTES de acordo com quem é cediço que as partes que pretenderem celebrar uma operação na qual um prêmio de controle deva ser considerado, devem fazê-la por meio de uma venda e compra de ações integrantes do bloco de controle, pois operações societárias como as incorporações não comportam mecanismos de distinção de avaliação de ações por estarem fora ou dentro de uma situação de controle. ${ }^{701}$

Feitas essas considerações sobre a admissibilidade de reconhecer um prêmio de poder de controle nas operações de incorporação em função da própria natureza jurídica da operação, passemos a analisar outros possíveis fatores que limitariam essa possibilidade.

\subsubsection{Possibilidade de Relações de Substituição Diferenciadas Perante os Demais Limites Impostos pela Lei das S.A.}

Além do que expusemos no item 3.4.1 supra, a admissibilidade de relações de substituição diferenciadas para ações da mesma espécie e classe esbarra também em outros limites impostos pela nossa lei societária, os quais já foram abordados nos capítulos anteriores.

O primeiro desses limites seria a necessidade de respeitar o tratamento equitativo entre todos os acionistas da mesma espécie e classe de ações. Retomando o que dissemos sobre o tema no item 2.3.2.3 supra, há casos em que o tratamento equitativo entre os acionistas pode ser afastado se isso for condição essencial para que a sociedade possa atingir seu interesse social e desenvolver suas atividades. No entanto, promover um tratamento não equitativo sem qualquer justificativa do ponto de vista do interesse social resulta apenas em um prejuízo indevido aos acionistas, sendo ilegítimo por parte do acionista controlador derrogar esse princípio por conta exclusivamente de sua vontade em repartir os benefícios e sacrifícios sociais de forma desigual entre os acionistas.

701 E. F. DE PONTES, Incorporação de ações no direito brasileiro... cit., p. 151. 
Expusemos neste trabalho que o interesse social nas incorporações é observado quando a operação proposta traz ganhos decorrentes das sinergias entre as companhias em função das possíveis economias ou benefícios que a operação gera, permitindo a maximização da rentabilidade dos acionistas. No entanto, essas sinergias em nada dependem de uma atuação diferenciada do acionista controlador a quem poderia caber desempenhar papéis específicos ou assumir maiores riscos, de forma que nada parece justificar a discriminação a seu favor em tais operações. Por outro lado, respeitar o tratamento equitativo assegura que sejam aprovadas apenas operações que atendam ao interesse social e que permitam a todos os acionistas participar dos benefícios delas decorrentes, o que não necessariamente se garantiria se o acionista controlador pudesse ter tratamento mais benéfico em relação aos demais. ${ }^{702}$

A obrigatoriedade de observar o tratamento equitativo entre todos os acionistas também já foi defendida para esses casos com base no art. 109, § 1. ${ }^{\circ}$, da Lei das S.A., que estabelece expressamente que as ações de cada classe conferirão iguais direitos aos seus titulares. Segundo o voto do diretor Eli Loria no caso Duratex/Satipel e Sadia/BRF Brasil Foods, todas as ações ordinárias devem ser tratadas igualmente, sendo inadmissível que as ações dos acionistas não controladores tenham tratamento diverso das ações detidas pelo controlador, não sendo o tratamento não isonômico passível de legitimação nem mesmo em assembleia que votem apenas os ordinaristas. ${ }^{703}$ Da mesma forma, outros autores como A. LAmy Filho, J. L. Bulhões Pedreira, M. CARVAlhosa, N. EIZIRIK e J. W. LuCEnA corroboram essa opinião ao dizer que o acionista tem o direito de exigir de parte da companhia e dos demais acionistas tratamento isonômico perante os demais acionistas da mesma classe com base no $\S 1 .^{\circ}$ do art. 109 da Lei das S.A ${ }^{704}$ na medida em que o princípio da igualdade dos acionistas deve ser apreciado sob duas vertentes: a igualdade formal de direitos incorporados à ação e atribuídos ao acionista e a igualdade substancial, que impede o tratamento discriminatório entre acionistas. A igualdade formal, portanto,

\footnotetext{
702 Argumento similar é utilizado por W. ANDREWS, The Stockholder's Right... cit., p. 517-519.

703 Vide Processo CVM n. RJ 2009/5811, rel. SEP, j. 28.07.2009; e Processo CVM n. RJ 2009/4691, rel. SEP, j. 11.08.2009.

704 Cf. A. LAMY Filho; J. L. Bulhões PEDReIRA (Coord.), Direito das companhias, v. 1, cit., p. 302-303; M. Carvalhosa, Comentários à Lei de Sociedades Anônimas, v. 2, cit., p. 364; N. EIZIRIK, A Lei das S/A comentada, v. I, São Paulo: Quartier Latin, 2011, p. 608; e J. W. LUCENA, Das sociedades anônimas - Comentários à Lei, Rio de Janeiro: Renovar, 2009, v. 1, p. 994. Vide também T. AsCARELLI, que afirma o direito à paridade de tratamento entre os acionistas da mesma categoria (Problemas das Sociedades Anônimas... cit., p. 337).
} 
centra-se no plano dos direitos que cada uma das ações confere ao seu titular, enquanto a igualdade substancial refere-se à maneira como a sociedade trata os acionistas concretamente diante de determinadas situações, como, por exemplo, no exercício do direito de preferência e em operações de reorganização societária. ${ }^{705}$ Nesse sentido, aliás, estabelecia o art. 78 do Decreto-lei n. 2.627/1940 ao impor a obrigação de igualdade de tratamento para todos os acionistas da mesma classe ou categoria. ${ }^{706}$

A nosso ver, portanto, o tratamento equitativo entre todas as ações da mesma espécie e classe é uma das limitações da determinação da relação de troca, assegurando que os acionistas não controladores ingressarão no capital da sociedade incorporadora em igualdade de condições com o acionista controlador. O resultado disso é que os minoritários estarão protegidos de uma relação de troca injusta pelo próprio interesse do controlador em aprovar uma relação de substituição de ações que seja simultaneamente vantajosa para todos os acionistas. Esse é, inclusive, como vimos nos capítulos antecedentes, um dos pressupostos básicos da Lei das S.A. sobre o qual se assenta a liberdade de negociação dos termos da relação de troca ${ }^{707}$ e alterar tal suposição poderia abrir frente a mecanismos perigosos que permitiriam a exploração dos minoritários em benefício exclusivo do controlador. Por essa razão, N. EIZIRIK entende ser recomendável que todos os acionistas da incorporada, titulares de ações da mesma espécie e classe, recebam ações da incorporadora com base na mesma relação de troca, a fim de não haver tratamento desigual entre controlador e minoritários. ${ }^{708}$ Da mesma forma, a minuta de regulação do CAF, tendo por principio básico a igualdade de tratamento dos acionistas,

705 Vide N. EIZIRIK, A Lei das S/A comentada, v. 1, cit. p. 608. Já discutimos no item 2.3.2.3 deste trabalho a dificuldade de se erigir o $\S 1 .^{\circ}$ do art. 109 a uma norma geral de tratamento equitativo para toda a Lei das S.A., pois o que esse artigo estabelece expressamente é um princípio de igualdade formal entre as ações, nada falando propriamente sobre o tratamento isonômico entre os acionistas. Não obstante, para o caso em questão, em que se discute a obrigatoriedade de que as mesmas ações estejam sujeitas à mesma relação de troca, ainda que não se admitisse a igualdade substancial dos acionistas, entendemos que tal artigo poderia ser aplicável, pois a relação de substituição é determinada em função da própria ação, sem levar em conta a perspectiva individual do acionista. O acionista não é parte do negócio de incorporação e a substituição de suas ações não depende de nenhum ato individualmente praticado por ele para que pudesse ser aventada uma possível discriminação no nível do acionista. Dessa forma, deveria prevalecer a igualdade de tratamento às ações independentemente da figura do acionista.

706 Decreto-lei n. 2.627/1940: “Art. 78. Nem os estatutos sociais, nem a assembléia geral poderão privar qualquer acionista:

a) do direito de participar dos lucros sociais, observada a regra da igualdade de tratamento para todos os acionistas da mesma classe ou categoria; $[\ldots]$ ".

707 Vide em sentido semelhante C. M. TOMAZELLA, Proteção de acionistas e credores... cit., p. 72.

708 Cf. A Lei das S/A comentada... cit., p. 405. 
aparentemente não permitirá incorporações que proponham relações de troca diferenciadas para ações da mesma espécie. ${ }^{709}$

Não obstante, já mencionamos neste trabalho que certas opiniões admitem a atribuição de um prêmio de controle para o acionista controlador em uma operação de incorporação. A justificação dessa teoria pode ser vista, por exemplo, nos argumentos defendidos por EASTERBROOK e FISCHEL que expusemos neste trabalho, segundo os quais seria razoável permitir operações que dividam os ganhos de forma desigual desde que os demais acionistas não sejam prejudicados, pois isso traria maiores ganhos na riqueza esperada dos acionistas e da sociedade em geral. ${ }^{710}$ Essa posição, no entanto, além de não ser livre de críticas também sob a perspectiva econômica, reflete uma maneira de encarar as operações de incorporação sob um prisma bastante comum na literatura americana, que é o de analisá-las como tantas outras formas para aquisição de uma companhia no contexto das operações de compra e venda de controle em que os acionistas são os protagonistas. ${ }^{711}$ Não obstante, entendemos que a própria natureza jurídica das incorporações e a forma como tal operação está estruturada no ordenamento jurídico brasileiro difere fundamentalmente dessa concepção e impede que tais operações possam ser examinadas a partir do ponto de vista dos acionistas e não das sociedades que as negociam. Aliás, a própria facilidade com que os norte-americanos veem as contraprestações admitidas nas

709 Cf. notícia veiculada no site da BM\&FBovespa, Entidades assinam convênio para constituição do CAF, disponível em < http://www.bmfbovespa.com.br/pt-br/noticias/2012/Entidades-assinam-convenio-paraconstituicao-do-CAF-2012-06-27.aspx?idioma=pt-br>, acesso em: 31 dez. 2013; e BM\&FBovespa formaliza criação do Comitê de Aquisições e Fusões, Valor Econômico, 27.06.2012, disponível em <http://www.valor.com.br/empresas/2730544/bmfbovespa-formaliza-criacao-do-comite-de-aquisicoese-fusoes>, acesso em: 31 dez. 2013.

710 Em sentido semelhante, vide opinião de S. M. BAINBRIDGE publicada em seu site < http:// Www.professorbainbridge.com/professorbainbridgecom/2007/07/paying-a-premium-for-supermajorityvoting-shares.html>, acesso em: 27 out. 2013.

711 Vide, por exemplo, F. H. EASTERBROOK e D. R. FISCHEL que analisam as mergers no contexto das corporate control transactions (The Economic Structure... cit., p. 109 e ss); e S. M. BAINBRIDGE que coloca tais operações entre os métodos de aquisição do controle de uma companhia ao lado da aquisição de ativos, tender offers ou aquisição de ações (Mergers and Acquisitions... cit., p. 16). Da mesma maneira, vide R. J. GILSON; B. S. BLACK, The Law and Finance... cit., p. 641; e L. A. BEBCHUK, Toward Undistorted Choice... cit., p. 1704. Nas próprias discussões da matéria, vê-se que é bastante comum lidar com as operações sob a óptica de uma compra e venda de ações realizada pelo controlador. Vide, por exemplo, os trechos em que, ao se discutir a posibilidade de prêmio na relação de troca no contexto de operações de incorporação, argumenta-se com base no "well-established principle that a controlling stockholder is entitled to sell his shares at a price that reflects a control premium" e que "[o]ne of the risks minority shareholders assume when they acquire stock in a corporation with a controlling shareholder is that the latter may sell at a premium without giving the minority an opportunity to participate" (Opinião de S. M. BAINBRIDGE publicada em seu site <http://www. professorbainbridge.com/professorbainbridgecom/2007/07/paying-a-premium-for-supermajority-votingshares.html>, acesso em: 27 out. 2013). 
operações de incorporação, permitindo que sejam entregues ações, dinheiro ou outros bens, contrasta radicalmente com a figura da incorporação em países de tradição romanogermânica em que o pagamento em ações é o pressuposto básico da operação, salvo alguns casos em que se admite o pagamento em dinheiro dentro dos limites permitidos, demonstrando que há um caráter de continuidade e manutenção do status socii nessas operações. $^{712}$

Na linha da teoria desenvolvida por D. C. GONÇALVES, já mencionamos a existência do princípio da identidade e da tutela do investimento como os limites do statuo viae utilizados para cercear a liberdade do controlador em alterar o investimento dos demais sócios e para determinar o eixo de equivalência em torno do qual se pode estabelecer a relação de troca. O princípio da identidade exige que a participação social antes e após a modificação societária seja ontologicamente a mesma, em um verdadeiro senso de continuidade. No item 2.3.2.3 deste trabalho em que discutimos a necessidade de se respeitar o tratamento equitativo, dissemos também que o princípio da identidade e a manutenção do status socii do acionista na nova empresa exigem a conservação da mesma ratio societária antes e depois da conclusão da operação, de forma que não haja alteração na posição relativa de um sócio perante os demais. Ora, admitir um prêmio de controle nas operações de incorporação é, justamente, desequilibrar essa posição relativa de um sócio em face dos demais e desrespeitar o princípio da identidade, de forma que não haveria equivalência entre o investimento do acionista na nova sociedade e o investimento por ele detido antes da conclusão da operação. Quanto ao princípio da tutela do investimento, há claramente uma hipertrofia na proteção do investimento do acionista controlador em detrimento da tutela do investimento do acionista não controlador. ${ }^{713}$ Não estariam observados, assim, os dois princípios informadores do statuo viae que devem reger a determinação da relação de troca das ações.

Por fim, vale também relembrar a posição de Marcos Barbosa Pinto no âmbito do Processo CVM n. RJ 2008/4156 quando diz que a dispensa da realização de oferta pública de aquisição de ações em casos de incorporação em que ocorre a troca de controle

\footnotetext{
712 D. C. GONÇALVES chega a dizer que "não é possível falar em fusão quando a contrapartida para os sócios das sociedade extintas não seja a atribuição de participações sociais na sociedade beneficiária. A contrapartida poderá não ser só a atribuição de participações sociais na sociedade beneficiária; mas tem que ser também e "sobretudo" essa atribuição" (Fusão, cisão e transformação... cit., p. 186).

713 Cf. E. F. DE PONTES, Incorporação de ações no direito brasileiro... cit., p. 219.
} 
se baseia, justamente, na prerrogativa de que há tratamento igualitário aos acionistas nas incorporações. ${ }^{714}$ No Brasil, a principal finalidade atribuída à oferta pública é a proteção dos minoritários com o intuito de evitar que sofram eventuais prejuízos patrimoniais e darlhes um mecanismo de saída em vista da alteração do acionista controlador. ${ }^{715}$ A princípio, portanto, sendo preservado o tratamento igualitário entre todos os acionistas, seria dispensável um mecanismo adicional de proteção como aquele previsto no art. 254-A da Lei das S.A., pois o próprio acionista controlador negociaria a melhor relação de troca para todos os acionistas simultaneamente.

Um segundo argumento utilizado para advogar o tratamento igualitário e refutar a admissibilidade de atribuição de um prêmio às ações do controlador nas operações de incorporação é de que isso implicaria criar classes de ações ordinárias, o que é vedado de acordo com o art. $15, \S 1 .^{\circ}$, da Lei das S.A. para as companhias abertas. ${ }^{716}$ Segundo M. CARvalhosa, classe é o elemento que distingue o direito de uma e outra ação, i.e., o conjunto de elementos que forma a identidade de direito, numa mesma emissão de capital. Dessa identidade, decorre a estrita igualdade para aquela classe. ${ }^{717}$ Entendido que o direito de receber determinada relação de troca no contexto de uma operação de incorporação é inerente à ação e não ao acionista, esse argumento parece fazer sentido na medida em que ações da mesma espécie estariam recebendo direitos diferentes e, portanto, poderiam ser consideradas como classes diferentes.

Outros limites impostos pela nossa Lei das S.A. que vedam a atribuição de um prêmio às ações do controlador por meio de uma relação de troca mais benéfica dizem respeito às regras de abuso de poder de controle e quebra dos deveres fiduciários dos administradores. A nosso entender, tais regras poderiam ser aplicadas mesmo que se argumentasse que a operação seja benéfica a todos os acionistas (ainda que mais benéfica

\footnotetext{
714 Vide Processo CVM n. RJ 2008/4156, rel. Dir. Sergio Weguelin, j. 17.06.2008.

715 Vide Parecer CVM/SJU n. 080 de 20.10.1981.

716 Além disso, mesmo para as ações ordinárias de companhia fechada, a Lei das S.A. foi taxativa ao estabelecer as diferenças em direitos que podem ser admitidas, excluindo a possibilidade de o estatuto social fazer outras distinções (cf. A. LAMY FILHO; J. L. BULHÕES PEDREIRA (Coord.), Direito das companhias, v. 1, cit., p. 237).

717 Comentários à Lei de Sociedades Anônimas, v. 2, cit., p. 365.
} 
ao acionista controlador) e que, portanto, estaria atendido o interesse social da companhia. $^{718}$

Quanto ao abuso do poder de controle, parece-nos estarmos diante do caso previsto no art. $117, \S 1 .^{\circ}, b$, da Lei das S.A. que classifica como medida abusiva "promover a incorporação da companhia com o fim de obter, para si ou para outrem, vantagem indevida, em prejuízo dos demais acionistas." Conforme expusemos acima, o prêmio de controle não deve ser admitido em operações de incorporação e tampouco pode ser admitida a derrogação do tratamento equitativo dos acionistas nesses casos, de forma que, se o controlador assim proceder, estaria se aproveitando de uma vantagem a que não tem direito nos termos da lei.

Além disso, cabe ao acionista controlador, no exercício de seus direitos fiduciários, defender os legítimos interesses de todos os acionistas, abstendo-se de restringi-los indevidamente. Por essa razão, mesmo que se tentasse argumentar que a operação atende ao interesse social porque gera a maximização da rentabilidade de todos os acionistas, parece-nos haver uma restrição indevida aos direitos dos minoritários que poderiam ter ganhos ainda maiores se fosse respeitado o tratamento equitativo. Aliás, como discutimos no item 2.3.2.1.1 a respeito dos critérios necessários para se considerar atendido o interesse social, a noção de maximização de rentabilidade do acionista se assenta sobre dois pressupostos: (i) aumento da capacidade da sociedade de produzir lucros ou fluxos de caixa futuros e (ii) conservação, e tentativa de aumento, da quota proporcional de participação dos sócios na sociedade pós-incorporação ou, em outras palavras, a existência de uma relação de troca tendencialmente "máxima". Não vemos, nesse caso, uma tentativa por parte do acionista controlador de obter um aumento da quota proporcional de todos os sócios na sociedade resultante e nem de uma relação de troca tendencialmente máxima, pois a participação dos minoritários seria, sem nenhuma dúvida, superior caso a relação de troca estabelecida não tivesse premiado o acionista controlador. Assim, nos termos defendidos neste trabalho, é possível dizer que o interesse social também não foi atendido em tais casos. Corroborando a configuração de abuso em tais casos, F. K. COMPARATO afirma que o acionista não pode obter pelo voto "vantagens que não são normalmente atribuídas a todos quantos se encontram na mesma situação jurídica perante a companhia;

718 Vide também C. M. TOMAZELla, Proteção de acionistas e credores... cit., p. 125-126. 
ou seja, uma violação do princípio da igualdade relativa que consubstancia a justiça distributiva". 719

No que tange ao papel dos administradores, mencionamos no item 2.3.2.5 em que analisamos seus deveres fiduciários, a obrigação de que os administradores negociem as operações de incorporação em benefício de todos os seus acionistas e não apenas do controlador ou dos acionistas que os elegeram, além de estarem obrigados a observar o interesse social na prática dos seus atos. Assim, entendemos que estaria configurada a quebra dos deveres fiduciários da administração caso seja negociada e proposta para aprovação uma relações de troca mais benéfica apenas ao controlador em detrimento dos demais acionistas e que, portanto, não corresponde ao interesse social. Advogando conforme esse entendimento, C. A. JUNQUEIRA DE SIQUEIRA diz que

ao oferecer uma quantidade maior de ações a determinado grupo de acionistas, sem nenhuma obrigação de fazê-lo, os administradores estão cometendo um ato de liberalidade e agindo de forma não equitativa. Vale lembrar ainda que, nessas operações, os antigos acionistas sofrem uma redução de participação relativa no capital da companhia, por conta da absorção do patrimônio da incorporada e consequente atribuição de ações aos acionistas recepcionados na incorporadora. Se essa atribuição é feita, estritamente, conforme o resultado das avaliações dos patrimônios, a diluição é inevitável, porém justificada. Mas, quando um grupo de acionistas recebe quantidades maiores - sem amparo legal -, tal ato não se justifica. $^{720}$

Não obstante nossa opinião e de tantos outros juristas sobre a ilegalidade das referidas operações, ${ }^{721}$ a CVM preferiu não impedi-las, mas regulá-las nos termos do PO CVM 34, conforme analisaremos em seguida.

719 Direito empresarial: estudos e pareceres, São Paulo: Saraiva, 1990, p. 90. No mesmo entendimento, N. J. PARENTE, Maioria não basta. Revista Capital Aberto... cit., p. 53.

720 Ato de liberalidade. Revista Capital Aberto... cit., p. 47.

721 Também advogam a ilegalidade da operação os Diretores Eli Loria e Otávio Yazbek no julgamento dos casos Duratex/Satipel e Sadia/BRF Brasil Foods; E. VALlADÃo A. E N. FRANÇA, Ainda o conceito de benefício... cit., p. 321; N. J. PARENTE, Maioria não basta. Revista Capital Aberto... cit., p. 52; C. M. TOMAZELlA, Proteção de acionistas e credores... cit., p. 127; E. F. DE PONTES, Incorporação de ações no direito brasileiro... cit., p. 213; e D. A. VIO; P. L. CASAGRANDE; R. P. FREOA, Conflito de interesse... cit., p. 176. 


\subsubsection{Parecer de Orientação CVM n. 34/2006}

A posição da CVM manifestada no PO CVM 34 aborda o problema das relações de troca diferenciadas à luz do $\S 1 .^{\circ}$ do art. 115 da Lei das S.A. ${ }^{722}$ De acordo com a autarquia, a relação de troca favorecida, sem que haja justificativa objetiva para tanto, constituiria um benefício particular e, por isso, o acionista controlador, bem como os demais acionistas que também sejam beneficiados, estariam impedidos de votar na assembleia geral que deliberar sobre a operação de incorporação nesses termos. Ainda segundo o referido parecer, seria possível, até mesmo, atribuir direito de voto aos titulares de ações preferenciais caso todas as ações ordinárias estivessem impedidas de votar.

Inicialmente redigido para regular operações de unificação das espécies de ações de companhias e a migração de companhias para segmentos especiais de negociação como o Novo Mercado, o PO CVM 34 se aplicaria exclusivamente às operações de incorporação de sociedade controlada em que as relações de substituição estabelecidas para as ações fossem diferentes em função de critérios não objetivos. ${ }^{723}$ Apesar disso, os preceitos do PO CVM 34 foram depois aplicados para operações negociadas entre partes independentes, por exemplo, nos casos Duratex/Satipel e Sadia/BRF Brasil Foods, tornando seu estudo ainda mais relevante.

722 Lei das S.A.: “Art. 115. O acionista deve exercer o direito a voto no interesse da companhia; considerarse-á abusivo o voto exercido com o fim de causar dano à companhia ou a outros acionistas, ou de obter, para si ou para outrem, vantagem a que não faz jus e de que resulte, ou possa resultar, prejuízo para a companhia ou para outros acionistas.

§ 1..$^{\circ}$ o acionista não poderá votar nas deliberações da assembléia-geral relativas ao laudo de avaliação de bens com que concorrer para a formação do capital social e à aprovação de suas contas como administrador, nem em quaisquer outras que puderem beneficiá-lo de modo particular, ou em que tiver interesse conflitante com o da companhia."

723 Vide D. KALANSKY, Incorporação de ações... cit., p. 105. Da mesma forma, o voto do Diretor Pedro Marcílio de Souza nos Processos CVM n. RJ 2006/7204 e n. RJ 2006/7213, rel. Dir. Luciana Pires Dias, j. 17.10.2006 diz que: "O parecer aplica-se, apenas, a incorporações que preencham os seguintes requisitos: (i) a companhia incorporadora não possui outros ativos significativos que não as ações da companhia incorporada; (ii) as ações do acionista controlador são avaliadas por um valor maior do que a do acionista ordinário não controlador ou do acionista preferencial; e (iii) não há um critério objetivo a validar o valor apresentado para as ações ordinárias”. Para E. F. DE PONTES, por sua vez, a não aplicabilidade do PO CVM 34 entre partes independentes é expressa no documento (Incorporação de ações no direito brasileiro... cit., p. 142). 
Com a edição desse parecer fica claro que a CVM, em vez de impedir as operações de incorporação em que se atribui um prêmio às ações do controlador, ${ }^{724}$ preferiu adotar uma estratégia de legitimação que impede o voto do controlador ao mesmo tempo que assegura a participação dos acionistas não controladores no processo decisório. ${ }^{725}$ Segundo a autarquia, a adoção de uma estratégia de proibição, além de cada vez menos utilizada, talvez também não fosse a solução ideal, pois apenas retardaria temporariamente a atuação dos acionistas controladores até que encontrassem soluções alternativas para exploração oportunista societária. Ademais, intervenções diretas dos órgãos reguladores poderiam ter piores resultados do que a atuação dos acionistas e administradores desinteressados, pois faltaria ao órgão regulador conhecimento específico da situação da companhia e dos acionistas. ${ }^{726}$

Não obstante, o PO CVM 34 foi bastante criticado pela doutrina por uma série de razões.

A primeira delas se liga à utilização do termo "benefício particular" para fundamentar o impedimento do voto do acionista nos termos do $\S 1 .^{\circ}$ do art. 115. Embora haja pouca divergência que as situações de benefício particular geram uma situação de impedimento de voto, a extensão do significado do termo é bastante polêmica. Uma interpretação literal do dispositivo poderia levar à conclusão de que o acionista estaria impedido de votar em todas e quaisquer hipóteses em que pudesse auferir um benefício (legítimo ou não) que não fosse partilhado com os demais acionistas, o que, na prática, aproximaria essa figura da tese daqueles que defendem o conflito de interesses sob uma óptica puramente formal. Essa posição, no entanto, parece-nos irreconciliável com outras normas da Lei das S.A. que não apenas reconhecem a possibilidade de um acionista ser contraparte da companhia, mas também que vote em deliberações que digam respeito ao

724 Como dissemos no item 2.3.2.3 supra, a autarquia poderia (e a nosso entender, deveria) ter vetado esse tipo de operação com o intuito de barrar práticas não equitativas no mercado, nos termos do art. $4 .^{\circ}$, VII, da Lei n. 6.385/76.

725 A estratégia de legitimação consiste, grosso moso, em permitir o voto apenas do acionista ou administrador independente, não ligado ao controlador. Sobre as diferentes estratégias regulatórias, entre elas as de legitimação, vide R. KRAAKMAN et. Al, The Anatomy of Corporate Law... cit., p. 37-45.

726 Vide Processo CVM n. RJ 2006/7204 e n. RJ 2006/7213, rel. Dir. Pedro Oliva Marcilio de Sousa, j. 17.10.2006. 
seu interesse (como, por exemplo, o próprio art. 264 da Lei das S.A., art. 115, § 4. ${ }^{\circ}$ e art. $\left.117, \S 1 .{ }^{\circ}, f\right) .{ }^{727}$

De acordo com E. VALlADÃo A. E N. FRANÇA, para que exista benefício particular,

[h]á de haver [...] um favor ao beneficiário, na sua condição de acionista, que recebe mais do que dá - Valverde e diversos outros autores acentuam o caráter contratual desse ato, em favor do interessado, rompendo o princípio da igualdade entre os sócios. Ou, de qualquer forma, uma situação em que não seja possível aferir, de antemão, o caráter comutativo do ato [...]. Como quer que seja, a lei permite tais vantagens, tratando-se, pois, de negócios lícitos. Conclui-se que o benefício particular é aquele em que há ou um negócio gratuito ou um negócio aleatório em favor do acionista (ou ainda de terceiros, como dispõe o art. 84 , inciso VI), vale dizer, em que não há comutatividade. ${ }^{728}$

Definido o que é o benefício particular, vê-se que as hipóteses previstas no PO

CVM 34 dele não se tratam, pois não decorrem de vantagens lícitas admitidas pela lei.

Mais uma vez, E. VALLADÃO A. E N. FRANÇA ensina que não se vê benefício particular nesses casos

em que se acha de antemão excluído pela lei, a toda evidência, qualquer caráter de permitida liberalidade a quem quer que seja na relação de substituição das ações da incorporada pela incorporadora, como se verifica das disposições inequivocamente cogentes do art. 264 da Lei das S/A, sendo possível apurar de plano, outrossim, se a operação é, ou não, equitativa. [...] Não há, pois, como evitar a conclusão de que não se trata,

727 Vide E. VALladÃO A. E N. FRANÇA, Conflito de interesses e benefício particular... cit., p. 38-41.

728 Ainda o conceito de benefício particular... cit., p. 319. No mesmo sentido, vide T. DE M. VALVERDE, que complementa a explicação sobre o caráter contratual do benefício particular afirmando que "o benefício ou a vantagem concedida ao acionista não adere às ações que por ventura ele possuir. É direito pessoal seu, ainda que negociável ou transmissível aos seus herdeiros, se assim tiver resolvido a assembleia geral, ou constar nos estatutos." (Sociedade por Ações - Comentários ao Decreto-Lei n. 2.627, de 26 de setembro de 1940, 3. ed., Rio de Janeiro: Forense, 1959, v. 2, p. 67). Ora, como viemos defendendo, a substituição das ações nas incorporações decorre de um negócio jurídico entre sociedades que não leva em conta a perspectiva do acionista individualmente, sendo que a relação de troca se estabelece em função da própria ação e não em função do acionista. Daí porque uma relação de troca diferenciada não poderia ser considerada um benefício particular do sócio, pois jamais seria uma vantagem contratualmente concedida ao acionista pela companhia como se entre eles houvesse qualquer tipo de negociação. Vide também E. VALLADÃO A. E N. FRANÇA, Temas de direito societário... cit., p. 576; E. VALlADÃO A. E N. FRANÇA, Conflito de interesses e benefício particular... cit., p. 43-44; e D. A. VIO; P. L. CASAGRANDE; R. P. FREOA, Conflito de interesse... cit., p. 170. 
nos casos mencionados, de hipóteses de benefício particular, mas, sim, de vantagens indevidas, caracterizadoras de conflito de interesses. ${ }^{729}$

Outra crítica feita ao PO CVM 34 é que a autarquia extravasa dos limites da lei ao impedir o voto do acionista controlador nas hipóteses previstas no parecer, alterando a estratégia de regulação da Lei das S.A. prevista no art. 264 - que optou nesse caso por fortalecer os direitos de informação do acionista e possibilitar um direito de saída mais robusto (como vimos no item 3.2 e seguintes) -, para uma estratégia de legitimação da operação em que os minoritários passaram a aprová-la. Em nenhum momento a lei previu o impedimento do voto do controlador ou a atribuição de direito de voto ao acionista preferencial ${ }^{730}$ e não há qualquer impedimento ao voto do acionista controlador na escolha dos peritos ou empresa especializada, na deliberação sobre o laudo de avaliação e muito menos na aprovação da operação de incorporação como um todo, ${ }^{731}$ de forma que a deliberação sobre a conveniência da incorporação continua a ser de competência discricionária da maioria acionária, e, como tal, é inquestionável pela minoria dos acionistas. $^{732}$

Com efeito, seria inaceitável proibir o voto do controlador deixando apenas aos minoritários decidir sobre a matéria, tornando letra morta o princípio da maioria em matéria de tamanha relevância. ${ }^{733}$ Além disso, poderia haver um claro questionamento a

729 Cf. Temas de direito societário... cit., p. 578-579; Vide, ainda, E. VALlADÃo A. E N. FRANÇA, Ainda o conceito de benefício particular... cit., p. 321; D. A. VIO; P. L. CASAGRANDE; R. P. FREOA, Conflito de interesse... cit., p. 176.

730 Vide E. VAlladão A. E N. FRANÇA, Ainda o conceito de benefício particular... cit., p. 321; L. L. CANTIDIANO, Análise crítica... cit., p. 41; D. KALANSKY, Incorporação de ações... cit., p. 114; e D. A. VIO; P. L. CASAGRANDE; R. P. FREOA, Conflito de interesse... cit., p. 162.

731 Cf. N. EIZIRIK, A Lei das S/A comentada... cit., p. 403.

732 Cf. F. SCARdulla, La Transformazione... cit., p. 406 e ss; L. G. P. B. LEÃES, Incorporação de companhia controlada... cit., p. 94; e E. F. DE PONTES, Incorporação de ações no direito brasileiro... cit., p. 209. Vide também opinião de E. VALLADÃO A. E N. FRANÇA ao dizer que "mesmo sabendo que o acionista controlador e os administradores determinam a vontade da companhia, a lei lhes dá a liberdade de ação, desde que pautem sua conduta pelo caráter de equitatividade, razoabilidade, comutatividade, sem proibir a prática do ato ou condicioná-lo à autorização de qualquer outro órgão." (Ainda o conceito de benefício particular... cit., p. 313).

733 Cf. N. EIZIRIK, A Lei das S/A comentada... cit., p. 403; A. LAMY FILHO; J. L. BULHÕES PEDREIRA (Coord.), Direito das companhias, v. 2, cit., p. 2045-2047; e C. SANTAGATA, La Fusione Tra Società... cit., p. 274. 
respeito do não cumprimento do quórum exigido para aprovação da incorporação na hipótese de o controlador majoritário abster-se de votar. ${ }^{734}$

Impedir o voto do controlador é também uma posição arriscada. Dependendo da composição acionária da sociedade, um ou mais minoritários de porte, com interesses relacionados aos do controlador, poderão prevalecer na assembleia. ${ }^{735}$ Ademais, nada garante que a minoria acionária esteja mais alinhada com o interesse social do que o controlador e o impedimento de voto deste último pode criar uma situação em que a minoria seja capaz de extrair benefícios particulares da operação. ${ }^{736}$ Nada impede também que uma minoria da minoria, que votou contra a operação, sinta-se lesada e peça reparação dos danos sofridos, o que poderia configurar até mesmo situação em que a responsabilidade pela decisão recaia sobre os minoritários que aprovaram a operação e não sobre o controlador. ${ }^{737}$ Aliás, ao permitir que incorporações nesse termos sejam realizadas mediante aprovação da maioria da minoria, sobra ao acionista minoritário que não concordou com a operação, se tanto, o direito de recesso, com todas as limitações que sobre ele recaem na lei societária brasileira, principalmente a questão do valor reduzido de reembolso, o qual geralmente não reflete a realidade econômica da companhia a que pertence o dissidente.

734 Cf. A. LAMY FILHO; J. L. BUlHõEs PEDREIRA, A Lei das S.A. (pressupostos, elaboração, aplicação)... cit., p. 681; M. CARVALHOSA; N. EIZIRIK, Estudos de direito empresarial... cit., p. 132; e E. VALLADÃO A. E N. FRANÇA, Temas de direito societário... cit., p. 345. Para driblar eventuais questionamentos, é comum que os controladores deixem os minoritários votarem e, posteriormente, sigam o voto por eles proferido. Alguns autores sugerem ainda haver espaço para um duplo conclave para tais operações, nas quais os não-controladores poderiam votar em separado sem que se retirasse o voto do controlador (cf. D. A. VIO; P. L. CASAGRANDE; R. P. FREOA, Conflito de interesse... cit., p. 189). E. F. DE PONTES, no entanto, entende que esse procedimento não seria correto porque a parte do negócio de incorporação é sempre a sociedade e não os acionistas e, portanto, os processos não deveriam ser mudados em nome deste ou daquele acionista, mas sim em nome da companhia como um todo, em um espaço unificado de debate (Incorporação de ações no direito brasileiro... cit., p. 40).

735 C. A. JUNQUEIRA DE SIQUEIRA, Ato de liberalidade... cit., p. 47.

736 Um dos problemas comumente relatados em situações como essa é a possibilidade de incentivar o que se chama de "strategic voting", em que a própria minoria pode pretender arrebatar para si uma importância dos benefícios da operação, ainda que uma parcela fique com o acionista controlador. $\mathrm{O}$ problema existe quando a minoria exige demais a ponto de uma operação eficiente ser descartada pelo controlador (cf. Z. GOSHEN, The Efficiency of Controlling Corporate Self-Dealing: The Theory Meets Reality, California Law Review, v. 91, n. 2, mar. 2003, p. 402-403). Vide também Vide E. S. MUNHOZ, Desafios do direito societário na companhia aberta... cit., p. 147-148; e D. KALANSKY, Incorporação de ações... cit., p. 110.

737 Essa situação poderia, inclusive, configurar um abuso de voto pela minoria (D. A. VIO; P. L. CASAGRANDE; R. P. FREOA, Conflito de interesse... cit., p. 171). É evidente que mesmo o acionista minoritário está obrigado a votar no interesse social, conforme dispõe o próprio art. 115 da Lei das S.A., sob pena de ficar configurado o abuso de voto, além de dever agir com lealdade perante os demais acionistas (vide M. V. VON ADAMEK, Abuso de minoria... cit., p. 131-132 e 147-150). 
É de se questionar também a eficácia do PO CVM 34 em impedir que o acionista controlador extraia benefícios particulares excessivos da companhia diante do fato de que a CVM, a princípio, permite que o acionista pertencente à classe afetada pelo "benefício particular" vote com as ações da outra classe não impedida, o que poderia fazer com que a operação fosse aprovada da mesma maneira, por exemplo, desde que o acionista controlador tivesse também ações preferenciais suficientes para aprovar a operação. ${ }^{738}$

Por fim, uma última crítica bastante precisa feita por E. F. DE PONTES é de que o PO CVM 34 tenta resolver um problema que é fundamentalmente patrimonial por meio da imposição de uma restrição aos direitos políticos do acionista. Em vez de mudar o regime de voto, diante da indisponibilidade de um mecanismo de tag along nesses casos, uma alternativa de regulação sugerida pelo autor é voltarmos para a questão dos appraisal rights inspirados no direito norte-americano, conforme também discutido no item 3.2.3 deste trabalho nas críticas ao PO CVM 35, permitindo uma reavaliação justa, adequada e escorreita do patrimônio detido por cada acionista, incrementada também por um mecanismo de peer review como o $\mathrm{CAF}^{739}$

Concordamos com as críticas feitas ao PO CVM 34. Primeiramente porque, a nossa ver, a autarquia deveria ter declarado ilegais tais operações de incorporação em que se atribui um prêmio às ações do controlador pelas razões todas que expusemos acima, sendo impossível legitimar essa prática mediante aplicação das regras de conflito de interesses. Permitir tais operações é fazer com que os minoritários descontentes não tenham nem a proteção da negociação de uma relação de troca adequada nem a proteção que existe em outras legislações como os appraisal rights do direito americano, que garantem um valor de reembolso muito mais substancioso ao dissidente.

Além disso, a escolha de regulação do PO CVM 34 por meio da proibição de voto parece ser ainda pior do que as alternativas propostas pelo PO CVM $35 .{ }^{740}$ Apesar de

738 A CVM entende que o impedimento de voto não incide sobre a pessoa dos acionistas, mas sim sobre as ações de determinada espécie ou classe (cf. Processo CVM n. RJ 2007/0947, rel. Dir. Marcelo Fernandez Trindade, j. 22.05.2007; e Processo CVM n. RJ 2006/6785, rel. Dir. Pedro Oliva Marcílio de Souza, j. 25.09.2006). Vide também C. TOMAZELlA, Proteção de acionistas e credores... cit., p. 125.

740 Vide, por exemplo, E. S. MUNHOZ ao dizer que a estratégia de regulação do PO CVM 35 é superior àquela do PO CVM 34 (Desafios do direito societário na companhia aberta... cit., p. 151). 
todas as críticas procedentes ao PO CVM 35, ao menos ele não exclui a participação do controlador do processo, mas busca criar incentivos para que as companhias desenvolvam suas próprias estruturas organizacionais para resolver a questão do conflito de interesses entre controlador e controlada, sugerindo mecanismos a serem livremente adotados pelas companhias e que tentam aproximar o resultado da operação ao que seria obtido de uma negociação entre partes independentes. ${ }^{741} \mathrm{O}$ PO CVM 34, ao contrário, resolve a questão impedindo o voto e deixando a decisão por conta da minoria (inclusive preferencialistas, a quem, a princípio, não deveria ser dado o direito de voto), o que pode ser igualmente danoso, além de não impedir de fato o voto do controlador com as ações que possuir na classe não impedida.

741 No mesmo sentido, vide D. A. ViO; P. L. CASAgrande; R. P. FreOA, Conflito de interesse... cit., p. 189-190. 


\section{4 \\ CONCLUSÃO}

Pelo exposto ao longo deste trabalho, faremos abaixo um arremate das principais teses aqui defendidas referentes à determinação da relação de substituição de ações:

i) as operações de incorporação de sociedade e de incorporação de ações são negócios jurídicos contratuais societários típicos que se formam pelo encontro de vontades de duas sociedades, as verdadeiras partes da operação, e que se diferenciam de outros institutos societários como aumento de capital, dissolução ou liquidação de sociedades, muito embora se utilizem ou se aproximem deles em algum momento;

ii) a natureza jurídica da relação de troca, mais do que corresponder a uma mera subrogação real de bens, identifica-se com a substituição de uma participação social por outra, tendo como pressuposto a manutenção do status socii dos acionistas da sociedade incorporada ou daqueles que têm suas ações incorporadas; essa manutenção do status socii decorre da dependência existente entre as antigas e as novas participações dos sócios e do caráter de continuidade das suas posições jurídicas no contexto de uma operação de concentração empresarial que se realiza entre sociedades e que não equivale, portanto, a troca individuais de participações societárias entre acionistas;

iii) a relação de troca se diferencia tanto de um preço privado negociado individualmente pelas partes como de uma mera declaração das sociedades cujo conteúdo e forma de apuração já esteja previamente disciplinado pela legislação; existe, sim, uma margem de negociação pelas companhias que reflete o próprio aspecto contratual típico da natureza jurídica dessas operações;

iv) a liberdade contratual existente na determinação da relação de substituição de ações é reforçada, inclusive, pelas normas que regulam os requisitos que devem constar no protocolo, notadamente a ampla liberdade na escolha dos critérios utilizados para determinar as relações de substituição, bem como pelas regras que tratam 
sobre a avaliação do patrimônio ou das ações a serem incorporadas ou sobre a manifestação dos peritos e conselheiros fiscais;

v) essa margem considerável de liberdade para a determinação da relação de substituição de ações foi conferida pela Lei das S.A. com base no pressuposto de que, tratando-se de companhias com controladores diversos, as operações de incorporação se resolvem como resultado de negociações em que os vários aspectos em jogo são livremente ponderados e que os administradores e acionistas controladores de cada uma das sociedades buscarão negociar os termos da operação da maneira mais conveniente para os seus interesses, simultaneamente protegendo o interesse dos acionistas minoritários; apesar disso, ainda que sem retirar essas características da Lei das S.A., entendemos que a regulação em torno da determinação da relação de troca poderia ter sido mais cuidadosa nos moldes do que existe hoje na legislação europeia, que regula com muito mais minúcia as regras do protocolo, das avaliações e o papel dos administradores e dos peritos especificamente na determinação, avaliação e justificação da relação de substituição de ações, sem, no entanto, retirar a margem de negociação da relação de troca pelas sociedades;

vi) embora exista liberdade na determinação da relação de substituição de ações, há ainda uma série de outras balizas legais que delimitam as fronteiras da sua livre negociação, uma vez que não se trata de um negócio puramente privado, mas sim de um negócio contratual-societário que se passa dentro do ordenamento jurídico das sociedades anônimas e que deve, portanto, observar as regras que visam à composição de uma série de outros interesses jurídicos que não apenas aquele do acionista controlador que aprova a operação;

vii) muitas vezes mencionado como um delimitador da relação de troca de ações, o princípio da realidade do capital social pouco auxilia na efetiva determinação do número de ações que será atribuído a cada acionista e, portanto, na proteção contra diluições injustificadas dos acionistas tanto da incorporadora quanto da incorporada (ou da sociedade cujas ações incorporadas), pois não se aplicam as regras de preço de emissão previstas no $\S 1 .^{\circ}$ do art. 170 da Lei das S.A. ao aumento de capital da incorporadora usualmente existente em tais operações; 
viii) a figura do interesse social funciona como alicerce de qualquer deliberação societária e, no caso das operações de incorporação, ajuda a definir um intervalo dentro do qual diferentes relações de substituição podem ser negociadas, mas sob a condição de que, em qualquer caso, chegue-se a uma maximização da rentabilidade do acionista com a concretização da operação de incorporação, seja pela expectativa de obter melhores resultados em termos de fluxos de caixa, lucros ou dividendos decorrentes das sinergias advindas da operação, seja pelo aumento da sua quota proporcional de participação na sociedade resultante da operação; nesse contexto, defendemos também que a relação de troca deveria sempre considerar as sinergias resultantes da operação de incorporação e sua forma de distribuição entre os acionistas, em vez de decorrer simplesmente da exata comparação entre os dois patrimônios das sociedades envolvidas (opusemos assim, o conceito de uma relação de troca "negocial" com uma relação de troca "pura"); em vista disso, tampouco seria obrigatória a manutenção de um determinado valor ao acionista de acordo com um critério preestabelecido, desde que fique demonstrado pela administração que a operação se presta à maximização da rentabilidade do acionista;

ix) o conceito de valor justo, geralmente mencionado como algo a ser perseguido na relação de troca, tem pouca serventia para efetivamente regular a relação de substituição de uma operação de incorporação, dadas as diferentes acepções que se atribuem a esse termo e a subjetividade do conceito; na realidade, o conceito de justiça pode corresponder a certo eixo de equivalência dentro do qual os administradores podem negociar diferentes relações de troca, desde que respeitem os princípios informadores do statuo viae (princípio da identidade e da tutela do investimento); além disso, essa ideia de justiça de uma operação pode estar associada mais à forma de negociação de uma operação, quando ela for similar ao que seria negociado entre partes independentes em um processo sem conflitos de interesses, do que efetivamente a um valor de relação de troca que seja intrinsecamente justo;

x) o significado do que seja tratamento equitativo, bem como a extensão de sua aplicabilidade nos casos de incorporação são bastantes controvertidos; não obstante, entendemos que a regra de tratamento equitativo - entendido como tratamento igualitário para acionistas da mesma espécie e classe de ações - deve ser seguido 
nas operações de incorporação, pois (a) dificilmente se conseguiria comprovar a necessidade de um tratamento não equitativo como condição para se atingir os ganhos decorrentes das operações de incorporação e alcançar o interesse social; e (b) a própria natureza jurídica de tais operações e da relação de troca impede um tratamento não equitativo na medida em que as novas participações devem respeitar o status socii anterior, sendo inválida a atribuição de participações como se houvesse negociações e trocas individuais de ações realizadas pelos sócios, os quais têm um papel secundário nessas operações;

xi) em defesa dos acionistas também está a obrigatoriedade dos administradores e dos controladores observarem seus deveres fiduciários, propondo e aprovando apenas operações que atendam ao interesse social de forma a maximizar a rentabilidade do acionista; os administradores também estão obrigados a tomar todas as diligências na negociação das operações, incluindo a correta avaliação da companhia e escolha dos critérios que determinarão a relação de troca enquanto o acionista controlador está obrigado a defender os interesses de todos os acionistas nesse processo;

xii) também vigem em favor de todos os acionistas regras que regulam a divulgação de informações e asseguram a diligência do processo como forma de fundamentar a relação de troca e conferir maiores garantias aos acionistas, permitindo que a relação de troca seja examinada e eventualmente contestada; ainda assim, entendemos que o nível informacional conferido ao acionista nos termos da Lei das S.A. é bastante baixo e deveria ser aprimorado, ainda mais quando comparado a outras legislações em solo europeu;

xiii) as operações de incorporação que envolvem companhias abertas têm particularidades além daquelas aplicáveis às demais companhias que são impostas, principalmente, pela ICVM 319; entre essas preocupações está a exigência de um maior nível de informações que devem ser colocadas à disposição dos acionistas, cuja importância, aliás, defendemos ao longo deste trabalho (por exemplo, divulgação dos benefícios esperados a serem obtidos com a operação, a estimativa dos custos de realização da operação e as razões pelas quais a operação é considerada equitativa); maiores mudanças ainda são aguardadas quando for 
publicada a instrução que reformará a ICVM 319 nos termos do Edital de Audiência Pública SDM n. 04/2013;

xiv) operações de incorporação envolvendo sociedades sob controle comum necessitam de regulação especial dada a inexistência de duas maiorias distintas para negociar os termos da operação; essa regulação especial, tratada pelo art. 264 da Lei das S.A., exerce uma dupla função: (a) oferecer aos acionistas não controladores informação adicional sobre a avaliação da incorporadora e sobre uma relação de troca teórica baseada na comparação direta dos patrimônios das sociedades; e (ii) servir como critério alternativo para o cálculo do valor de reembolso aos acionistas dissidentes;

xv) a regulação especial prevista no art. 264 da Lei das S.A. em nada altera o entendimento sobre a obrigatoriedade de que a relação de troca atenda ao interesse social na forma descrita neste trabalho, pois, embora se baseie em uma relação de troca "pura", isso não significa que se está abrindo mão da obrigatoriedade da maximização da rentabilidade do acionista como requisito de validade das operações; além disso, nesses casos, muitos autores recomendam que a relação de troca de ações não se distancie muito da relação de troca "pura", justamente por faltar a independência das partes na negociação que poderia levar a uma relação de troca "negocial" que seja ao mesmo tempo justa porque negociada entre partes independentes;

xvi) de maneira geral, o art. 264 oferece proteção limitada aos acionistas, pois, combinado com uma legislação que permite ampla margem de negociação na relação de troca, não atinge os dois principais problemas das operações de incorporação entre sociedades sob controle comum, que são a possibilidade de aprovação pelo controlador de uma relação de troca prejudicial nas assembleias e a influência de tal acionista na administração das sociedades envolvidas, além de pouco resolver a questão da insuficiência do direito de recesso;

xvii) as ações preferenciais (ou ainda, cada uma das ações de espécie e classe distinta) podem ter relações de troca diferenciadas de forma que, além de uma paridade relativa entre as ações ordinárias, deverá ser estabelecida também uma paridade 
especial em relação às ações preferenciais; essa possibilidade existe porque, em tais casos, o princípio da igualdade entre todos os sócios pode ser afastado para permitir a diferenciação entre as diferentes espécies e classes de ações como uma exigência natural de refletir os diversos direitos incorporados às ações a fim de reconstruir, na sociedade que recebe os acionistas, o equilíbrio que existia entre os sócios antes da realização da operação; essa possibilidade, inclusive, está em linha com a ideia de reconstrução do mesmo status socii que existia na sociedade original e do caráter de continuidade das participações sociais;

xviii) para respeitar a paridade "interna" e promover a diferenciação entre as ações de diferentes espécies e classes, os administradores deveriam estimar, de modo analítico e objetivo, o conteúdo dos direitos patrimoniais atribuíveis às diversas categorias de ações (ordinárias, de um lado, e preferenciais, do outro); entretanto, como tais procedimentos comportam escolhas subjetivas e chegam a um resultado final dificilmente comprovável, a solução privilegiada na prática consiste em determinar os valores das diversas espécies de ações em proporção aos respectivos preços de bolsa apurados, portanto, por uma avaliação realizada por todo o mercado (mas desde que a cotação em bolsa reflita adequadamento o valor das ações);

xix) a atribuição de uma relação de troca diferenciada entre ações da mesma espécie e classe com base no argumento de que as ações do acionista controlador são merecedoras de um prêmio é ilegal; em primeiro lugar, porque as operações de incorporação em tudo se distinguem das alienações de poder de controle em que esse prêmio é reconhecido, sendo inviável alegar a existência de um sobrevalor para o controlador nas operações de incorporação; essa inviabilidade decorre, aliás, da própria natureza jurídica da incorporação como negócio entre sociedades em que a figura do acionista (controlador ou não) é secundária e não deveria interferir na determinação da relação de substituição de ações; a inadmissibilidade dessa prática deveria ser ainda constatada em função da quebra do tratamento equitativo entre os acionistas da mesma espécie e classe de ações em desrespeito ao art. 109, § 1. ${ }^{\circ}$, da Lei das S.A., desrespeito ao princípios da identidade e da tutela do investimento informadores do statuo viae, criação de classe de ações ordinárias em companhias abertas e por abuso de poder de controle e quebra dos deveres fiduciários da administração, inclusive por não atendimento ao interesse social; e 
xx) tanto o PO CVM 34 quanto o PO CVM 35 foram criados para lidar substancialmente com o mesmo problema, i.e., o conflito entre controladores e minoritários na aprovação da relação de substituição das ações, mas adotam estratégias de regulação substancialmente diferentes, sendo o primeiro baseado principalmente no impedimento de voto do controlador e o segundo basicamente no detalhamento dos deveres fiduciários da administração, sugerindo a criação de comitês independentes que aproximem a negociação da operação ao que ocorreria entre partes independentes; embora a forma de regulação proposta pelo PO CVM 35 nos pareça superior quando comparada ao PO CM 34, ambos os pareceres criam mecanismos que têm sua legalidade e eficácia bastante controvertidas e que pouco se adaptam à estrutura da nossa Lei das S.A.; além disso, os pareceres em questão não atacam de frente o problema fundamental que é a contraprestação recebida pelo acionista seja na relação de troca de ações ou no seu direito de saída da companhia; é hora, portanto, de pensar em soluções alternativas para o problema, como um enrobustecimento dos mecanismos de saída por valor justo com base nos appraisal rights do direito americano e submissão de tais operações a um mecanismo de peer review como já vem sendo proposto pelo CAF. 


\section{REFERÊNCIAS}

ADAMEK, Marcelo Vieira Von, Abuso de minoria em direito societário (abuso das posições subjetivas minoritárias). Tese (Doutorado) - Faculdade de Direito da Universidade de São Paulo, 2010.

ADAMEK, Marcelo Vieira Von. Responsabilidade civil dos administradores de S/A e as ações correlatas. São Paulo: Saraiva, 2010.

AGUIAR, Danilo Augusto Barboza de. Proteção dos acionistas minoritários das Sociedades Anônimas abertas como forma de promover o desenvolvimento do Mercado de Capitais nacional - Alteração no regime legal das ações preferenciais. Revista de Direito Bancário, de Mercado de Capitais e da Arbitragem, São Paulo: RT, ano 6, n. 22, p. 88-127, 2003.

AHMUD, Yakov; LEV, Baruch. Risk Reduction as a Managerial Motive for Conglomerate Mergers. In: ROMANO, Roberta. Foundations of Corporate Law. Nova York: Foundation Press, 2003.

ALLAN, Robert M. Expansion by Merger. In: ALBERTS, William W.; SEGALL, Joel E. The corporate merger. Washington: Beardbooks, 2003.

ANDREWS, William. The Stockholder's Right to Equal Opportunity in the Sale of Shares. 78 Harv. L. Rev., 1965.

ANGELICI, Carlo. Parità di Trattamento degli Azionisti. Rivista del Diritto Commercialli e del Diritto Generale delle Obbligazioni, I, 1987.

ANGELIS, Lorenzo de. Le operazioni di transformazione, fusione e scissione nella legge delega per la riforma del diritto societário. Rivista Delle Società, Milano: Giuffrè, ano 47, fasc. 1, p. 41-77, 2002.

ANSOFF, Igor; MCDONNEL, Edward. Implanting Strategic Management. 2. ed. Harlow, Essex: Prentice Hall, 1990. 
ANTUNES, José A. Engrácia. O artigo 490 do CSC e a Lei Fundamental - "Propriedade corporativa", propriedade privada e igualdade de tratamento. Estudos em comemoração dos cinco anos (1995-2000) da Faculdade de Direito da Universidade do Porto. Coimbra: Coimbra Editora, 2001.

ARAGÃO, Leandro Santos de. Dever de informar e operações de reorganização societária procedimento preparatório e as informações assimétricas. In: ARAGÃO, Leandro Santos de; CASTRO, Rodrigo R. Monteiro de (Org.). Reorganização societária. São Paulo: Quartier Latin, 2005.

ARAGÃO, Paulo Cezar; LIMA, Monique M. Mavignier de. Incorporação de controlada: a disciplina do art. 264 da Lei 6.404/76. In: PERIN JÚNIOR, Ecio; KALANSKY; D.; PEYSER, L. (Org.). Direito empresarial: aspectos atuais de direito empresarial brasileiro e comparado. São Paulo: Método, 2005.

ARAGÃO, Paulo Cezar. O Parecer de Orientação 35/2008 da CVM. In: ADAMEK, Marcelo Vieira Von (Coord.). Temas de direito societário e empresarial contemporâneos. Brasil: Malheiros, 2011.

ASCARELli, Tullio. Problemas das Sociedades Anônimas e direito comparado. 2. ed. São Paulo: Saraiva, 1969.

ASCARELLI, Tullio. Studi in tema di Società. Milano: Giuffrè, 1952.

BAINBRIDGE, Stephen. Mergers and Acquisitions. New York: Foundation Press, 2003.

BARBUIO, Ana C.; ZORICIC, Ana C. C.; ALCADE, Roberto F. V. Incorporação de sociedade e incorporação de ações. Incidência do art. 254-A da Lei das Sociedades Anônimas. In: E. S. Munhoz, M. R. PEnTEAdo (Coord.). Mercado de Capitais brasileiro: doutrina, cases \& material. São Paulo: Quartier Latin, 2012.

BAUDEU, Guy; BELlARGENT, Guy. Fusion de sociétés. Fascicule 164 C. Paris: Librairies techniques, 1970.

BEBCHUK, Lucian Arye. Toward Undistorted Choice and Equal Treatment in Corporate Takeovers, 98 Harv. L. Review, 1984-1985. 
BEBCHUK, Lucian Arye. The case for increasing shareholder Power. Harvard Law Review, v. 118, n. 3, p. 836-914. Disponível em: <http://papers.ssrn.com/sol3/papers. cfm?abstract_id=387940>. Acesso em: 8 jun. 2012.

BERLE JR., Adolf A.; MEANS, Gardiner C. The Modern Corporation and Private Property. New York: Macmillan, 1933.

BIANCHI, Luigi Arturo. Il Giudizio di "Congruità" del Rapporto di Cambio nella Fusione. Universitá degli Studi di Trento, 1993.

BITZER, Klaus. Probleme der Prüfung des Umtauschverhältnisses bei aktienrechtlichen Verschmelzungen. Pfaffenweiler: Centaurus-Verlagsgesellschaft, 1987.

BLACK JR., Lewis S. Why Corporations Choose Delaware, Delaware Department of State Division of Corporations, 2007. Disponível em: <http://corp.delaware. gov/whycorporations_web.pdf>. Acesso em: 12 fev. 2012.

BREALEY, Richard A.; MYERS, Stewart C. Principles of Corporate Finance. 7. ed. McGraw-Hill, 2003.

BROWN JR., J. Robert. Discrimination, Managerial Discretion and the Corporate Contract, 26 Wake Forest L. Review, 1991.

BRUDNEY Victor. A Restatement of Corporate Freezeouts, 87 Yale L. J., 1977-1978.

. Equal Treatment of Shareholders in Corporate Distributions and Reorganizations, 71 Cal. L. Rev., 1983.

- Standards of Fairness and the Limits of Preferred Stock Modifications, 26 Rutgers L. Rev. 445, 1972-1973.

; CHIRELSTEIN, Marvin A. Fair Shares in Corporate Mergers and Takeovers, 88 Harv. L. Rev., 1974-1975.

BRUNER, Robert F. Applied Mergers \& Acquisitions. New Jersey: Wiley Finance, 2004.

BULGARELLI, Waldirio. A fusão, incorporação e cisão de Sociedades Anônimas, na Lei Nova das Sociedades por Ações. Revista de Direito Mercantil Industrial, Econômico e Financeiro, São Paulo: RT, n. 23, p. 39-52, 1976. 
Apontamento sobre o conselho fiscal na reforma da Lei $\mathrm{n}^{0}$ 6.404/76. In: BULGARELli, Waldirio (Coord.). Reforma da Lei das Sociedades por Ações. São Paulo: Pioneira, 1998.

A incorporação das Sociedades Anônimas. São Paulo: Universitária de Direito, 1975.

. Fusões, incorporações e cisões de sociedades. 5. ed. São Paulo: Atlas, 2000.

. Regime jurídico da proteção às minorias nas S/A. Rio de Janeiro: Renovar, 1998.

BRUNETTI, Antonio. Trattato del Diritto delle Società - Società per Azioni. Milano: Giuffrè, 1948.

CAMACHO, Marília; MAKANT, Barbara. Da utilização do instituto da incorporação de ações como meio de efetuar o fechamento de capital de uma companhia aberta sem a realização de oferta pública. Revista de Direito Bancário e do Mercado de Capitais, São Paulo: RT, ano 8, n. 28, p. 46-69, 2005.

CAMPOS BATALHA, Wilson de Souza. Comentários à Lei das Sociedades Anônimas. Rio de Janeiro: Forense, 1976. v. 3.

CANTIDIANO, Luiz Leonardo. Alienação e aquisição de controle. Revista de Direito Bancário e do Mercado de Capitais, São Paulo: RT, n. 34, pp. 330-344, 2006.

Análise crítica do Parecer de Orientação CVM 34. Revista de Direito Bancário e do Mercado de Capitais, São Paulo: RT, n. 41, p. 133-147, 2008.

Incorporação de sociedades e incorporação de ações. In: CASTRO, Rodrigo R. Monteiro de; MOURA AZEVEDO; Luís André N. de (Coord.). Poder de controle e outros temas de direito societário e Mercado de Capitais. São Paulo: Quartier Latin, 2010.

Reforma da Lei das S.A. comentada. Rio de Janeiro: Renovar, 2002.

CARNEY, William J. Mergers and Acquisitions - Cases and Materials. New York: Foundation Press, 2000. 
CARVALHO DE MENDONÇA, José Xavier. Tratado de direito comercial brasileiro. 4. ed. Rio de Janeiro - São Paulo: Freitas Bastos, 1963. v. 3 e 4.

CARVAlHOSA, Modesto de Souza Barros. Comentários à Lei de Sociedades Anônimas. 4. ed. São Paulo: Saraiva, 2009. v. 1, 2,3 e 4, t. I e II.

Da inexigibilidade da realização de OPA prévia à incorporação de ações. Revista de Direito Bancário, de Mercado de Capitais e da Arbitragem, São Paulo: RT, n. 40, p. 161-173, 2008.

; EIZIRIK, Nelson. A Nova Lei das S/A. São Paulo: Saraiva, 2002.

CARVAlHOSA, Modesto de Souza Barros; EIZIRIK, Nelson. Estudos de direito empresarial. São Paulo: Saraiva, 2010.

CASTRO NEVES, Maria Cecília de. Incorporação de sociedade com patrimônio líquido negativo. Revista Forense, Rio de Janeiro: Forense, v. 345, p.103-120, 1999.

CLARK, Robert. Corporate Law. Boston, Toronto: Little, Brown and Company, 1986.

COELHO, Sasha Calmon Navarro. Imposto sobre a renda e incorporação de ações da sociedade "Holding". Revista Dialética de Direito Tributário, n. 77, p. 178-179, fev. 2002.

COFFEE JR., John C. Transfer of Control and the Quest for Efficiency: Can Delaware Law Encourage Efficient Transactions while Chilling Inefficient Ones?, 21 Del. J. Corp. L. 359, 1996.

CHOPER, Jesse H.; COFFEE, JR., John C.; GILSON, Ronald J. Cases and Materials on Corporations. 5. ed. New York: Aspen Publishers, 2000.

COMPARATO, Fábio Konder. A fixação do preço de emissão das ações no aumento de capital da sociedade anônima. Revista de Direito Mercantil Industrial, Econômico e Financeiro, São Paulo: RT, n. 81, p. 79-86, 1991.

. Direito empresarial: estudos e pareceres. São Paulo: Saraiva, 1990.

Novos ensaios e pareceres de direito empresarial. Rio de Janeiro: Forense, 1981. 
. O novo direito de retirada do acionista nos casos de fusão e incorporação. Revista de Direito Mercantil Industrial, Econômico e Financeiro, São Paulo: Malheiros, n. 116, p. 11-16, 1999.

; SALOMÃO FILHO, Calixto. O poder de controle na Sociedade Anônima. 4. ed. Rio de Janeiro: Forense, 2005.

CORDEIRO, António Menezes. Manual de direito das sociedades. 2. ed. Coimbra: Almedina, 2007. v. 1 e 2.

COZIAN, Maurice; VIANDIER, Alain; DEBOISSY, Florence. Droit des Sociétés. 19. ed. Paris: Litec, 2006.

CRETELLA JUNIOR, José. Tratado de desapropriação. Rio de Janeiro: Forense, 1980. v. 1.

CUNHA, Rodrigo Ferraz Pimenta da. Estrutura de interesses nas Sociedades Anônimas: hierarquia e conflitos. São Paulo: Quartier Latin, 2007.

CUNHA PEIXOTO, Carlos Fulgêncio da. Sociedade por ações. São Paulo: Saraiva, 197273. v. 5.

D’ALESSANDRO, Floriano. La Seconda Diretiva e la parità di tratamento degli azionisti. Rivista delle Società, I, p. 1-13, 1987.

D'ATTORRE, Giacomo. Il Principio di Egualianza tra Soci nelle Società per Azioni. Milano: Giuffrè, 2007.

DAMODARAM, Aswath. Investment Valuation: Tools and Techniques for determining the value of Any Asset. 2. ed. New York: Wiley Finance, 2002.

DAVIES, Paul. Introduction to Company Law. 2. ed. New York: Oxford, 2010.

DOMINGUES DE ANDRADE, Manuel A. Teoria geral da relação jurídica. Coimbra: Almedina, 2003. v. 1 e 2.

EASTERBROOK, Frank H.; FISCHEL, Daniel R. The Economic Structure of Corporate Law. Cambridge: Harvard University Press, 1991. 
EIZIRIK, Nelson. A Lei das S/A comentada. São Paulo: Quartier Latin, 2011. v. 1 e 3. Incorporação de ações: aspectos polêmicos. In: WARDE JR., Walfrido J. (Org.). Fusão, cisão, incorporação e temas correlatos. São Paulo: Quartier Latin, 2009.

. Notas sobre o direito de recesso na incorporação, fusão e cisão das companhias. Revista de Direito Mercantil Industrial, Econômico e Financeiro, São Paulo: Malheiros, n. 133, p. 124-129, 1999.

. Reforma das S.A. e do Mercado de Capitais. Rio de Janeiro: Renovar, 1998.

Temas de direito societário. Rio de Janeiro: Renovar, 2005.

; GAAL, Ariadna B.; PARENTE, Flávia; HENRIQUES, Marcus de Freitas. Mercado de capitais: regime jurídico. 3. ed. Rio de Janeiro: Renovar, 2011.

FABRETTI, Láudio Camargo. Incorporação, fusão, cisão e outros eventos societários: tratamento jurídico, tributário e contábil. São Paulo: Atlas, 2001.

FERREIRA, Waldemar. Tratado de direito comercial. São Paulo: Saraiva, 1961. v. 4.

FERRI, Giuseppe. Le Società. 2. ed. Torino: Utet, 1985.

FERRO-LUZZI, Paolo; CHIAPPETTA, Francesco. Fusione e prestiti obbligazionari di società per azioni. Rivista delle Società, Milano: Giuffrè, ano 50, fasc.1, 2005.

FISCHER, Rodolfo. Las sociedades anónimas: su régimen jurídico. Tradução do alemão por W. Roces. Madrid: Reus, 1934.

FRANÇA, Erasmo Valladão Azevedo e Novaes. Ainda o conceito de benefício particular: anotações ao julgamento do processo CVM RJ-2009/5.811. Revista de Direito Mercantil Industrial, Econômico e Financeiro, São Paulo: Malheiros, n. 149/150, p. 293-322, 2008.

- Conflito de interesses e benefício particular: uma distinção que se impõe definitivamente dirimir. Revista de Direito Mercantil Industrial, Econômico $e$ Financeiro, São Paulo: Malheiros, n. 161/162, p. 38-46, 2012. 
FRANÇA, Erasmo Valladão Azevedo e Novaes. Temas de direito societário, falimentar e teoria da empresa. São Paulo: Malheiros, 2009.

(Org.). Direito societário contemporâneo I. São Paulo: Quartier Latin, 2009.

GALGANO, Francesco. Diritto Commerciale. Le Società: Contrato di Società. Società di Persone. Società per Azioni, Altre Società di Capitali. Società Cooperative. Bologna: Zanichelli, 2005.

Tratatto di Diritto Commerciale e di Diritto Pubblico Dell'Economia. La Società per Azioni. Padova: Cedam, 1984. v. 7.

GARRIGUES, J.; URIA, R. Comentario a la Ley de Sociedades Anónimas. Madrid: Instituto de Estudios Politicos, 1953. t. I e II.

GARRIGUES Y DÍAZ-CAÑABATE, Joaquín. A Sociedade Anônima e os acionistas. Revista de Direito Bancário, de Mercado de Capitais e da Arbitragem, São Paulo: RT, n. 15, p. 267-280, 2002.

GAUGHAN, Patrick. Merger, Acquisition and Corporate Restructutrings. 5. ed. Hoboken, NJ: Wiley \& Sons, 2011.

GILSON, Ronald J.; BLACK, Bernard S. The Law and Finance of Corporate Acquisitions. 2. ed. New York: The Foundation Press, 1995.

GILSON, Ronald J.; GORDON, Jeffrey N. Controlling Controlling Shareholders. Columbia Law and Economics Working Paper No. 228, s.1., 2003. Disponível em: <http://papers.ssrn.com/sol3/Papers.cfm?abstract_id=417181>. Acesso em: $12 \mathrm{dez}$. 2010.

GONÇALVES, Diogo Costa. Fusão, cisão e transformação de sociedades comerciais: a posição jurídica dos sócios e a delimitação do statuo viae. Coimbra: Almedina, 2008.

GONÇALVES NETO, Alfredo de Assis. A fusão, a incorporação e a cisão na Lei de Sociedade por Ações. Revista de Direito Mercantil Industrial, Econômico e Financeiro, São Paulo: RT, n. 23, p. 71-82, 1976. 
GONÇALVES NETO, Alfredo de Assis. Direito de empresa. 2. ed. rev. e atual. São Paulo: RT, 2008.

GOSHEN, Zohan. The Efficiency of Controlling Corporate Self-Dealing: The Theory Meets Reality. California Law Review, v. 91, n. 2, mar. 2003.

GOWER, L.C.B. Principles of Modern Company Law. London: Sweet \& Maxwell, 1992.

GUERREIRO, José Alexandre Tavares. Direito das minorias na Sociedade Anônima. Revista de Direito Mercantil, Industrial, Econômico e Financeiro, São Paulo: RT, n. 63, p. 106-111, 1986.

GUERREIRO, José Alexandre Tavares. Sociologia do Poder na Sociedade Anônima. Revista de Direito Mercantil Industrial, Econômico e Financeiro, São Paulo: RT, n. 77, p. 50-56, 1990.

GUIRÃO, Miguel Motos. Fusión de Sociedades Mercantiles. Madrid: Editorial Revista de Derecho Privado, 1953.

HALPERIN, Isaac. Sociedades Anónimas. 2. ed. Buenos Aires: Depalma, 1978.

HAMERMESH, Lawrence. Premiums in Stock-for-Stock Mergers and Some Consequences in the Law of Director Fiduciary Duties. University of Pennsylvania Law Review, v. 152, n. 2, Dec. 2003.

HAUSER, Enrique A. Fusión de empresas. Buenos Aires: Macchi, 1967.

HOFSTETTER, Karl. One size does not fit all: Corporate Governance for "Controlled Companies". Revised Draft, Harvard Law School, June 20, 2005. Disponível em: <http://papers.ssrn.com/sol3/papers.cfm?abstract_id=802705>. Acesso em: 17 ago. 2013, p. 48.

HOPT, Klaus J. Comparative Company Law. ECGI - Law Working Paper No. 77/2006, 2006. Disponível em: 〈http://ssrn.com/abstract=980981〉. Acesso em: 10 jun.2012.

JENSEN, Michael C.; RUBACK, Richard S. Market for Corporate Control: Scientific Evidence. In: ROMANO, Roberta. Foundations of Corporate Law. Nova York: Foundation Press, 2003. 
JENSEN, Michael C.; MECKLING,William H. Theory of the Firm: Managerial Behavior. Agency Costs and Ownership Structure. In: Journal of Financial Economics, v. 3, n. 4, 1976. Disponível em: <http://papers.ssrn.com/sol3/papers.cfm?abstract_id=94043>. Acesso em: 8 jun. 2012.

KALANSKY, Daniel. Incorporação de ações: estudos de casos e precedentes. São Paulo: Saraiva, 2012.

KRAAKMAN, Reinier et al. The Anatomy of Corporate Law - A Comparative and Functional Approach. 2. ed. New York: Oxford University Press, 2009.

LAMY FILHO, Alfredo. Temas de S.A. - exposições e pareceres. Rio de Janeiro: Renovar, 2007.

; PEDREIRA, José Luiz Bulhões. A Lei das S/A.: pressupostos, elaboração, aplicação. Rio de Janeiro: Renovar, 1992.

LAMY FILHO, Alfredo; PEDREIRA, José Luiz Bulhões. A Lei das S.A. - Parte III Pareceres. 2. ed. Rio de Janeiro: Renovar, 1996. v. 2.

; __ (Coord.). Direito das Companhias. Rio de Janeiro: Forense, 2009. v. 1 e 2 .

LAZZARESCHI NETO, Alfredo Sérgio. Lei das Sociedades por Ações anotada. 3. ed. São Paulo: Saraiva, 2010.

LEÃES, Luiz Gastão Paes de Barros. Incorporação da totalidade das ações de companhias controladas. Revista de Direito Bancário, de Mercado de Capitais e da Arbitragem, São Paulo: RT, n. 40, p. 170-173, 2008.

. Incorporação de companhia controlada. Revista de Direito Mercantil Industrial, Econômico e Financeiro, São Paulo: Malheiros, n. 94, p. 87-96, 1994.

Pareceres. São Paulo: Singular, 1989. V. 2.

LIMA, Osmar Brina Corrêa. Incorporação de empresas. Belo Horizonte: Del Rey, 1993.

LOBO, Jorge. Direito de retirada nos casos de fusão, incorporação, cisão e participação em grupos de sociedades. Revista dos Tribunais, São Paulo: RT, v. 664, p. 43-49, 1991. 
Direitos dos acionistas. Rio de Janeiro: Elsevier, 2011.

Reforma da Lei das Sociedades Anônimas. Rio de Janeiro: Forense, 2002.

LUCENA, José Waldecy. Das Sociedades Anônimas: Comentários à lei. Rio de Janeiro: Renovar, 2009. v. 1 e 2.

MACHADO, Rubens Approbato. Sociedade por ações - incorporação, fusão e cisão direito de retirada. Revista de Direito Mercantil Industrial, Econômico e Financeiro, São Paulo: Malheiros, n. 82, p. 46-61, 1991.

MARCHI, Eduardo C. Silveira. Guia de metodologia jurídica. Lecce: Del Griffo, 2004.

MARGONI, Anna Beatriz Alves; GUERREIRO, Carolina Dias Tavares. Exercício abusivo do poder de controle e o dever de reparar o dano. In: MONTEIRO DE CASTRO, Rodrigo R.; WARDE JUNIOR, Walfrido; TAVARES GUERREIRO, Carolina Dias (Coord.). Direito empresarial e outros estudos em homenagem ao Professor José Alexandre Tavares Guerreiro. São Paulo: Quartier Latin, 2013.

MARTINS, Eliseu. Avaliação de empresas: da mensuração contábil à econômica. 5. ed. São Paulo: Atlas, 2006.

MARTINS, Fran. Comentários à Lei das Sociedades Anônimas. Rio de Janeiro: Forense, 1978. v. 3.

MCGUINNESS, Michael J.; REHBOCK, Timo. Going-Private Transactions: A Practitioner's Guide, 30 Del. J. Corp. L. 437, 2005.

MENGONI, Luigi. Appunti per una revisione della teoria sul conflitto di interessi nelle deliberazioni della società per azioni. Rivista delle Società, 1956.

MOREIRA, Ricardo Guimarães. Do preço justo no cancelamento de registro de companhia aberta. Revista de Direito Empresarial, n. 4, jul.-dez. 2005.

MUNHOZ, Eduardo Secchi. Aquisição de controle acionário: alienação e tomada. 2011. Tese (Livre-docência em Direito Comercial) - Faculdade de Direito da Universidade de São Paulo. 
Desafios do direito societário na companhia aberta: avaliação dos sistemas de controle diluído e concentrado. In: ARAGÃO, Leandro Santos de; CASTRO, Rodrigo R. Monteiro de (Org.). Direito societário: desafios atuais. São Paulo: Quartier Latin, 2008.

Empresa contemporânea e direito societário. São Paulo: Juarez de Oliveira, 2002.

MUNIZ, Ian; CASTELO BRANCO, Adriano. Fusões e aquisições: aspectos fiscais e societários. São Paulo: Quartier Latin, 2007.

OPPO, G. Eguaglianza e contratto nelle società per azioni. Rivista di Diritto Civile, 1974.

PARENTE, Flávia. O dever de diligência dos administradores de Sociedades Anônimas. Rio de Janeiro: Renovar, 2005.

PARENTE, Norma Jonssen. O direito de recesso na incorporação, fusão ou cisão de sociedades. Revista de Direito Mercantil Industrial, Econômico e Financeiro, São Paulo: Malheiros, n. 97, p. 67-75, 1995.

Maioria não basta. Revista Capital Aberto, São Paulo: Capital Aberto, fev. 2007.

PEDREIRA, José Luiz Bulhões. 25 anos da CVM. Revista da CVM, Rio de Janeiro, n. 35, 2003.

PENTEADO, Mauro Bardawil. The efficacy of intra-corporate approvals in negotiated mergers between controlling shareholder and its corporation under Delaware and Brazilian law. Revista de Direito Mercantil Industrial, Econômico e Financeiro, São Paulo: Malheiros, n. 143, p. 76-105, 2006.

PENTEADO, Mauro Rodrigues. Aumentos de capital das Sociedades Anônimas. São Paulo: Saraiva, 1988.

Reorganização operacional e societária. Ação declaratória de nulidade de deliberações de conselho de administração de S.A. Suposto conflito de interesses. Revista de Direito Mercantil Industrial, Econômico e Financeiro, São Paulo: Malheiros, n. 146, p. 237-268, 2007. 
PEREIRA, Guilherme Doring Cunha. Alienação do poder de controle acionário. São Paulo: Saraiva, 1995.

PÉREZ TROYA, Adoración. La determinación del tipo de canje en la fusión de sociedades. Madrid: Marcial Pons, 1998.

PONTES, Evandro Fernandes de. Incorporação de ações no direito brasileiro. 2013. Tese (Doutorado) - Faculdade de Direito da Universidade de São Paulo.

PONTES DE MIRANDA, Francisco Cavalcanti. Tratado de direito privado. 3. ed. Rio de Janeiro: Borsoi, 1972. t. LI.

RIBEIRO, Renato Ventura. Incorporação de Companhia Controlada. In: WARDE JR., Walfrido J. (Org.). Fusão, cisão, incorporação e temas correlatos. São Paulo: Quartier Latin, 2009.

RIPERT, G.; ROBLOT, R.. Traité de Droit Commercial. 17 ed. Paris: L.G.D.J., 1998, t. 1. RODRÍGUEZ, Carlos Juan Zavala. Fusión y escisión de sociedades. Buenos Aires: Depalma, 1976.

ROLL, Richard. The Hubris Hypothesis of Corporate Takeovers. In: ROMANO, Roberta. Foundations of Corporate Law. Nova York: Foundation Press, 2003.

SADDI, Jairo (Org.). Fusões e aquisições: aspectos jurídicos e econômicos. São Paulo: IOB, 2002.

SALOMÃO FILHO, Calixto. O novo direito societário. 4. ed. São Paulo: Malheiros, 2011.

SANCHEZ OLIVÁN, Jose. La fusión de sociedades. Estudio económico, jurídico y fiscal. 3. ed. Madrid: Editorial de Derecho Reunidas, 1993.

SANTAGATA, Carlo. La fattispecie della fusione. In: GRIFFI, Antonio Patroni (Org.). Fusioni e Scissioni di Società. Milano: Giuffrè, 1995. La Fusione Tra Società. Napoli: Morano, 1964.

SCARDULLA, Francesco. La Transformazione e La Fusione Delle Società. Milano: Giuffrè, 1989. 
SCHLIECKMANN, Clarisse Mello Machado. Aspectos societários da incorporação de ações de controlada envolvendo companhia aberta. Monografia apresentada ao Departamento de Direito da Pontifícia Universidade Católica do Rio de Janeiro para Obtenção do Título de Bacharel em Direito. Disponível em: <http://www.maxwell.lambda.ele.puc-rio.br/16767/16767.PDF>. Acesso em: 7 ago. 2013.

SCHWARTZ, Samuel. Merger Analysis as a Capital Budgeting Problem. In: ALBERTS, William W.; SEGALL, Joel E. The corporate merger. Washington: Beardbooks, 2003.

SCHULMAN, Stephen; SCHENK, Alan. Shareholders' Voting and Appraisal Rights in Corporate Acquisition Transactions, 38 Bus. Law, 1982-1983. Disponível em: <http://heinonline.org>. Acesso em: 9 jun. 2012, p. 1529-1555.

SILVA, Lucila. O valor justo em incorporação de sociedades controladas. São Paulo: Almedina, 2011.

SIMONETTO, Ernesto. Delle societá - transformazione e fusione dele società, società costituite all'estero od operante all'estero. 2. ed. Roma: Zanichelli, 1976.

SIQUEIRA, Carlos Augusto Junqueira de. Fechamento do Capital Social: oferta pública de aquisição de ações e outras modalidades. São Paulo: Migalhas, 2010.

SUBRAMANIAN, Guhan. Fixing freezeouts. The Yale Law Journal, v. 115:2. Disponível em: 〈http://www.yalelawjournal.org/pdf/115-1/Subramanian.pdf>. Acesso em: 12 jun. 2012.

SZTAJN, Rachel. Fusão, incorporação e cisão de sociedades: formas de reorganização da estrutura societária na Lei n.9457/97. In: BULGARELLI, Waldirio (Coord.). Reforma da Lei das Sociedades por Ações. São Paulo: Pioneira, 1998.

TANTINI, Giovanni. Transformazione e Fusione delle Società. In: GALGANO, Francesco. Tratatto di Diritto Commerciale e di Diritto Pubblico Dell'Economia. Padova: Cedam, 1985. v. 8.

TEIXEIRA, Egberto Lacerda; GUERREIRO, José Alexandre Tavares. Das Sociedades Anônimas no direito brasileiro. São Paulo: Bushatsky, 1979. 
TOMAZELlA, Carla Mosna. Proteção de acionistas e credores nas operações de incorporação envolvendo Sociedades Anônimas. 2011. Dissertação (Mestrado) Faculdade de Direito da Universidade de São Paulo.

VALVERDE, Trajano Miranda. Sociedade por Ações - Comentários ao Decreto-Lei n. 2.627, de 26 de setembro de 1940. 3. ed. Rio de Janeiro: Forense, 1959. v. 2 e 3.

VENTURA, Raúl. Fusão, cisão, transformação de sociedades - Comentário ao Código das Sociedades Comerciais. 3. a reimp. da 1. ed. de 1990. Coimbra: Almedina, 2006.

VICARI, Andrea. Gli Azionisti nella Fusione di Società. Milano: Giuffrè, 2004.

VIO, Daniel Avila; CASAGRANDE, Paulo Leonardo; FREOA, Ricardo Peres. Conflito de interesse na incorporação e incorporação de ações - o Parecer de Orientação n. 34/06 e Parecer de Orientação n. 35/08 da CVM. In: MUNHOZ, Eduardo Secchi; PENTEADO, Mauro Rodrigues (Coord.). Mercado de Capitais Brasileiro: doutrina, cases \& material. São Paulo: Quartier Latin, 2012.

WALD, Alexandre. A proteção dos acionistas minoritários na alienação do controle de companhias abertas. Revista de Direito Bancário e do Mercado de Capitais, São Paulo: RT, n. 34, p. 345-367, 2006.

WALD, Arnoldo. Considerações sobre aquisição e alienação de controle societário: o estudo da jurisprudência. Revista dos Tribunais, São Paulo: RT, v. 691, p. 13-25, 1993.

Direito de preferência e a incorporação de ações em outra sociedade. Revista de Direito Mercantil Industrial, Econômico e Financeiro, São Paulo: Malheiros, n. 46, p. 5-14, 1992.

A oferta pública, igualdade dos acionistas e o direito comparado. Revista de Direito Mercantil Industrial, Econômico e Financeiro, São Paulo: RT, n. 43, p. 15-18, 1981.

WARDE JR., Walfrido Jorge. Os poderes manifestos no âmbito na empresa societária e o caso das incorporações: a necessária superação do debate pragmático-abstracionista. In: CASTRO, Rodrigo R. Monteiro de; MOURA AZEVEDO; Luís André N. de (Coord.). 
Poder de controle e outros temas de direito societário e Mercado de Capitais. São Paulo: Quartier Latin, 2010.

WESTON, J. Fred. The Determination of Share Exchange Ratios in Mergers. In: ALBERTS, William W.; SEGALL, Joel E. The corporate merger. Washington: Beardbooks, 2003.

WIEDEMANN, Herbert. Gesellschaftsrecht: ein Lehrbuch des Unternehmens- und Verbandsrechts. München: Beck, 1980.

WILLIAMSON, Oliver E. Mergers, acquisitions, and leveraged buyouts: an efficiency assessment. In: BEBCHUK, L. A. Corporate Law and Economic Analysis. Cambridge: Cambridge University, 1990.

WILLIAMSON, Oliver E. The Modern Corporation: Origins, Evolution, Attributes. Journal of Economic Literature, v. XIX, 1981. Disponível em: <http://www.jstor.org/stable/2724566>. Acesso em: 8 jan. 2010.

XAVIER, Alberto. Incorporação de ações: natureza jurídica e regime tributário. In: CASTRO, Rodrigo R. Monteiro de; ARAGÃO, Leandro Santos de (Coord.). Sociedade Anônima 30 anos da Lei 6.404/76. São Paulo: Quartier Latin, 2007.

ZANINI, Carlos Klein. A doutrina dos "fiduciary duties" no direito norte-americano e a tutela das sociedades e acionistas minoritários frente aos administradores das Sociedades Anônimas. Revista de Direito Mercantil Industrial, Econômico e Financeiro, São Paulo: Malheiros, ano XXXVI, p. 137-149, 1998.

Outros:

WOLF, Daniel E. Kirkland \& Ellis LLP, Time is money - ticking fees. Disponível em: <http://blogs.law.harvard.edu/corpgov/2013/10/18/time-is-money-ticking-fees/>. Acesso em: 14 nov. 2013.

Incorporações continuam a premiar bloco de controle. Revista Capital Aberto, n. 71, p. 89, jul. 2009. 
Independência dos Comitês de Incorporação está à prova. Revista Capital Aberto, n. 69, p. 8-9, maio 2009.

Preferencialistas felizes. Revista Capital Aberto, n. 73, p. 66-67, set. 2009.

Selo da paz. Revista Capital Aberto, n. 108, ago. 2012; e Selo de qualidade, Revista Capital Aberto, n. 96, ago. 2011.

Será tudo encenação. Revista Capital Aberto, n. 71, p. 26, jul. 2009.

Uma questão de valores. Revista Capital Aberto, n. 74, p. 22-26, out. 2009. 